INSTITUTO DE PESQUISAS ENERGÉTICAS E NUCLEARES Autarquia associada à Universidade de São Paulo

\author{
DESENVOLVIMENTO E VALIDAÇÃO DE METODOLOGIA \\ ANALÍTICA PARA DETERMINAÇÃO DE DISRUPTORES \\ ENDÓCRINOS RESULTANTES DE ATIVIDADES ANTRÓPICAS \\ NAS ÁGUAS DA REGIÃO DO RIO PARAÍBA DO SUL, SP
}

Renata Rodrigues de Souza

Dissertação apresentada como parte dos requisitos para obtenção do Grau de Mestre em Ciências na Área de Tecnologia Nuclear - Materiais.

Orientadora:

Dra. Elâine Arantes Jardim Martins

São PaUlo

2011 
Dedico...

Aos mens pais, Eliézio e Perpétuapor me ensinarem que o conhecimento é $\sigma$ bem mais valioso, pelo amor e confiança. 


\begin{abstract}
AGRADECIMENTOS
"O valor das coisas não está no tempo que elas duram, mas na intensidade com que acontecem. Por isso existem momentos inesqueciveis, coisas inexplicáveise
\end{abstract} pessoas incomparáveis".

FERNANDO PESSOA

A Deus, por estar sempre ao meu lado, pela oportunidade concedida, pela saúde e força.

À minha família, sem a qual não teria chegado até aqui. Meus pais, Eliézio e Perpétua, por minha educação e formação, pelo amor e confiança depositados em mim. À minha irmã Raquel, pelo apoio e incentivo.

Ao David, meu principal incentivador, por estar sempre ao meu lado e não me deixar desanimar. Agradeço ainda pelo amor, cumplicidade, paciência e compreensão.

À Dra. Elâine Arantes Jardim Martins, por exercer seu papel de maneira brilhante e saber o verdadeiro significado da palavra orientação. Obrigada por acreditar na minha capacidade de realizar este trabalho, pelo carinho, amizade e constante estímulo.

Ao Dr. Hélio Akira Furusawa, pela valiosa participação desde o início deste estudo, principalmente pelas contribuições e sugestões durante o processo de validação da metodologia.

Ao Dr. Oscar Vegas pelo aporte no equipamento e ensinamentos sobre espectrometria de massas. Ao Dr. Jorge Vaz, pela pronta disposição a nos ajudar e pelos ensinamentos sobre cromatografia gasosa.

Ao Instituto de Pesquisas Energéticas e Nucleares, IPEN/CNEN e ao Centro de Química e Meio Ambiente, CQMA, pela infra-estrutura disponibilizada para realização deste projeto.

À Dra. Maria A. F. Pires e à Dra. Marycel E.B. Cotrim, pelo apoio institucional, disponibilização dos laboratórios e equipamentos.

À SABESP, pela parceria e colaboração neste projeto de pesquisa, em especial à Eng. Martha Rosângela e aos funcionários da Divisão de Controle Sanitário-RVOC da SABESP de São José dos Campos, pelas coletas.

Meu muito obrigada às minhas irmãs de orientação, Juliana lkebe e Danúbia Fernandes, pelo trabalho em equipe e valiosíssimo auxílio no laboratório. 
Pela amizade e momentos de descontração. Sem vocês essa jornada teria sido muito mais difícil!

Aos amigos formados desde a iniciação científica, Lilian Polakiewicz, Janara Matos, Carlos F. Brito, Tatiane Araújo, Douglas Batista, Carina Magdalena e Renan Azevedo, pelo convívio e por tornarem minha passagem pelo CQMA ainda mais prazerosa. Agradeço especialmente às amigas Viviane Martins e Camila Lange, sempre dispostas a me ouvir e ajudar, e que muito contribuíram para este trabalho.

A todos os funcionários da pós-graduação do IPEN e do CQMA, pela presteza e cortesia com que sempre fui tratada. Obrigada aos funcionários: Wagner Terazan, que inúmeras vezes, prontamente, nos auxiliou no "trabalho pesado", Cristina Sisti e Cleide Moreira, pelo empréstimo de materiais e análises.

Ao CNPq pela bolsa concedida e apoio financeiro. 
“...E você aprende que realmente pode suportar... que realmente é forte, e que pode ir muito mais longe depois de pensar que não se pode mais. E que realmente a vída tem valor e que vocé tem valor diante da vída". 


\title{
DESENVOLVIMENTO E VALIDAÇÃo DE METOdOLOGIA ANALÍTICA PARA DETERMINAÇÃO DE DISRUPTORES ENDÓCRINOS RESULTANTES DE ATIVIDADES ANTRÓPICAS NAS ÁGUAS DA REGIÃo do RıO PARAíbA dO SUL, SP
}

\section{RENATA RODRIGUES DE SOUZA}

\begin{abstract}
Resumo
Neste estudo foi realizada a avaliação de seis substâncias sintéticas resultantes de processos industriais e de atividades antropogênicas - dietilftalato, dibutilftalato, nonilfenol, pentaclorofenol, bisfenol A e benzo[a]pireno - os quais possuem capacidade de interferir negativamente no funcionamento normal do sistema endócrino de animais e de seres humanos (xenoestrógenos), em águas tratada e bruta de quatro municípios do Vale do Paraíba paulista. Para tanto, utilizou-se um método analítico de alta seletividade e sensibilidade, sendo a determinação por cromatografia gasosa acoplada ao detector de espectrometria de massas (GC/MS), precedida da concentração das amostras pelo método SPE (extração em fase sólida). Como não são suficientes apenas boas técnicas analíticas para garantir a qualidade dos dados gerados e a confiabilidade dos resultados, a metodologia desenvolvida foi submetida ao processo de validação, onde foram avaliados os parâmetros: seletividade, especificidade, linearidade, faixa linear de trabalho, limites de detecção e quantificação, precisão, exatidão, recuperação e robustez, além da incerteza na medição. Os resultados demonstraram que o método proposto é adequado para quantificação das amostras do rio Paraíba do Sul, e pela sua aplicação foi constatada a presença de todos os poluentes estudados tanto na água bruta quanto na potável em pelo menos um dos três períodos de amostragem, sendo as maiores concentrações mensuradas nas águas brutas e no período seco. Estes resultados evidenciam que as atividades antrópicas na região influenciam a qualidade da água do recurso hídrico estudado, bem como a qualidade da água de distribuição.
\end{abstract}




\title{
DEVELOPMENT AND VALIDATION OF ANALYTICAL METHODOLOGY FOR DETERMINATION OF ENDOCRINE DISRUPTORS FROM ANTHROPIC ACTIVITIES IN WATERS AT REGION OF PARAíba do SUl RIVER, SP
}

\section{RENATA RODRIGUES DE SOUZA}

\begin{abstract}
The evaluation of six synthetics substances from industrials process and anthropogenic activities - diethyl phthalate, dibuthyl phthalate, nonylphenol, pentachlorophenol, bisphenol A and benzo[a]pyrene - which one can interfer negatively in normal function of the endocrine system from animals and humans (xenoestrogens), was carried out in this study in drinking water and raw water on four cities at region of Paraíba do Sul River. An analytical method with high selectivity and sensitivity, with determination by gas chromatography coupled to mass spectrometry detector (GC/MS), preceded of samples concentration through the SPE technique was used. Good analytical techniques are not enough to ensure quality and reliability of the generated data results. For this, the methodology was submitted to the validation process, where parameters evaluated were: selectivity, specificity, linearity, work range, detection and quantification limits, precision, accuracy, robustness, percentage of recovery and uncertainty in measurement. The validation results showed that proposed method is suitable to quantify Paraíba do Sul river samples, and by its application could observe presence of all studied pollutants in drinking and raw water in one of the three sampling periods at least, and the highest measured concentrations were in raw water at dry periods. These results evidence that the anthropic activities at region are influencing the water quality of the studied water resource, as well as the quality of water for public supply.
\end{abstract}




\section{SUMÁRIO}

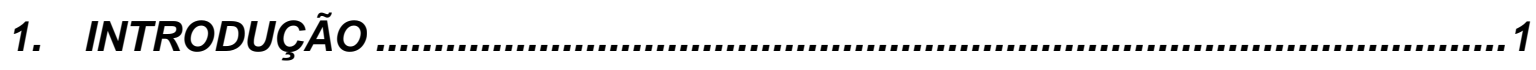

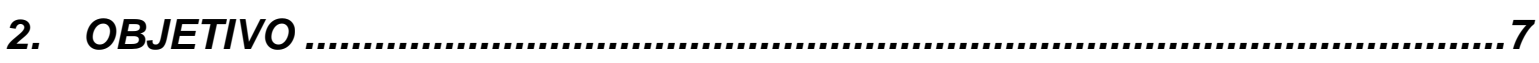

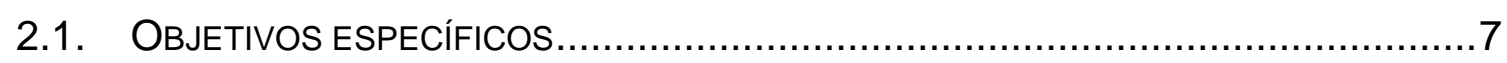

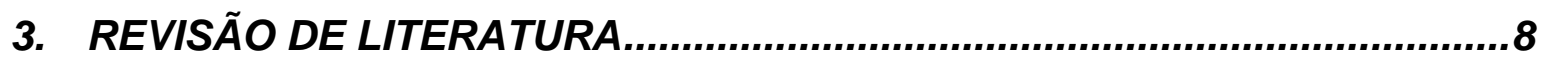

3.1. PROdUÇÃO dE SUBSTÂNCIAS QUÍMICAS PELA SOCIEDADE MODERNA $\ldots \ldots \ldots \ldots \ldots . . . . . . .8$

3.2. DISRUPTORES ENDÓCRINOS: HISTÓRICO E EVIDÊNCIAS DE DISFUNÇÃO ...........10

3.3. SISTEMA ENDÓCRINO E MODOS DE AÇÃO DOS INTERFERENTES HORMONAIS..... 15

3.4. CARACTERIZAÇÃO DOS COMPOSTOS DE INTERESSE.................................. 18

3.4.1. Ftalatos................................................................................. 20

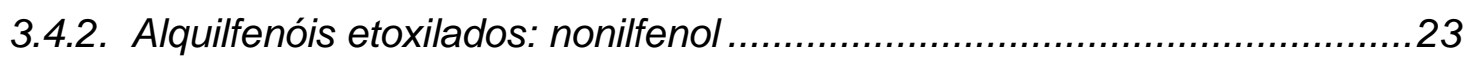

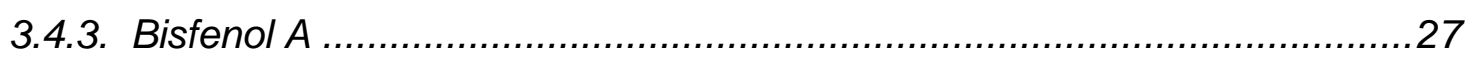

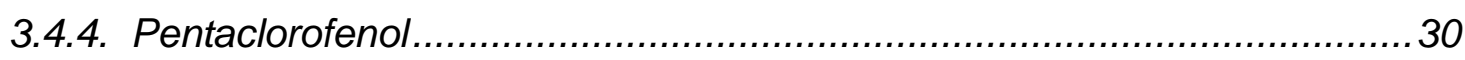

3.4.5. Hidrocarbonetos policíclicos aromáticos: benzo[a]pireno ........................ 33

3.5. LEGISLAÇÕES NACIONAIS E INTERNACIONAIS SOBRE DES EM ÁGUAS ...............36

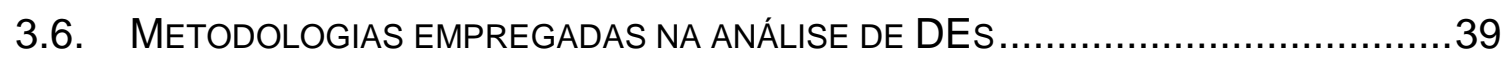

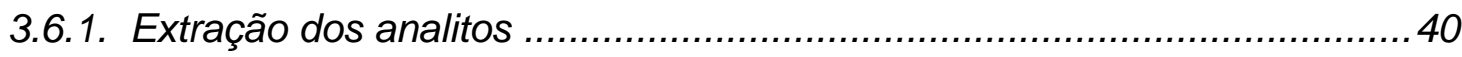

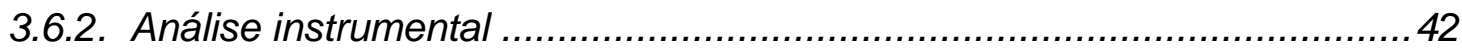

3.7. DETERMINAÇÃO DE XENOESTRÓGENOS EM AMOSTRAS AQUOSAS ...................48

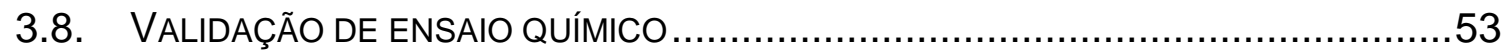

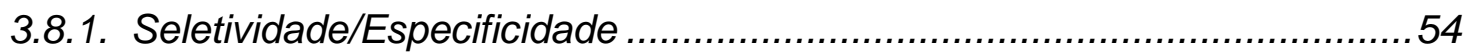

3.8.2. Linearidade e Faixa linear de trabalho ................................................. 54

3.8.3. Limites de detecção e quantificação ................................................. 57

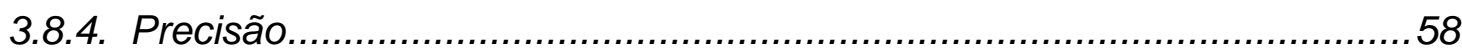

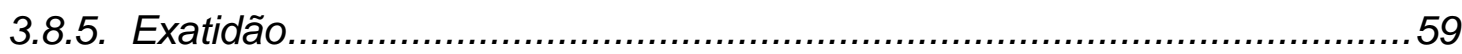

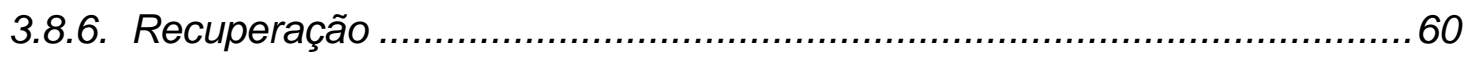

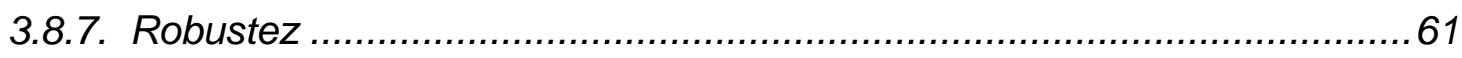

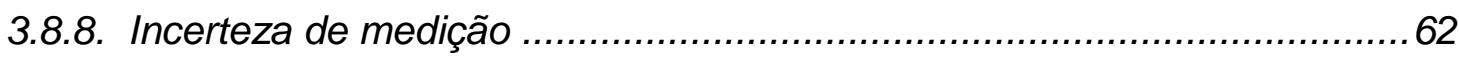

3.8.8.1. Diagrama de Causa e Efeito (Ishikawa ou Espinha de peixe) .........64 


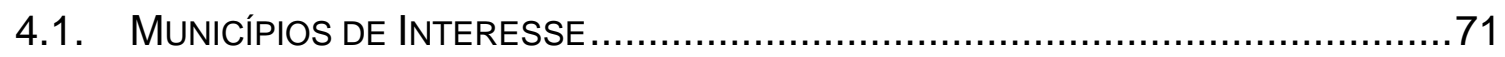

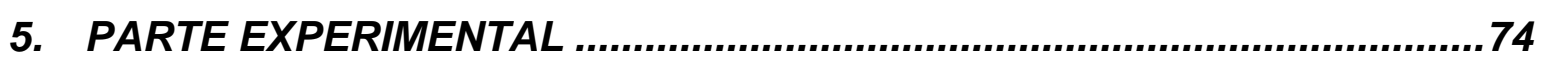

5.1. REAGENTES, MATERIAIS E EQUIPAMENTOS ........................................... 74

5.2. CONSIDERAÇÕES SOBRE CONTAMINAÇÃO ..................................................76

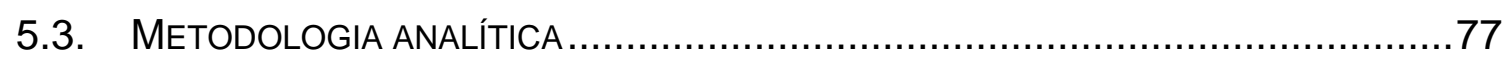

5.3.1. Estudos preliminares para extração dos DEs ….................................. 77

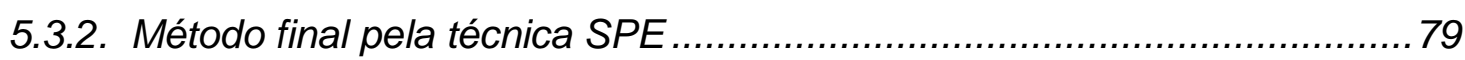

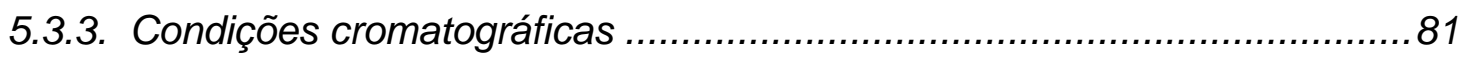

5.3.4. Quantificação das amostras por GC/MS.......................................... 82

5.4. AVALIAÇÃO DOS PARÂMETROS DE DESEMPENHO ANALÍTICO.............................83

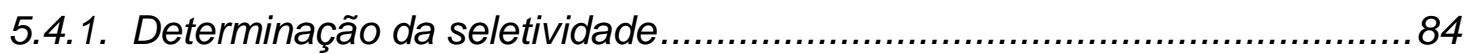

5.4.2. Determinação da linearidade e da faixa linear de trabalho .......................87

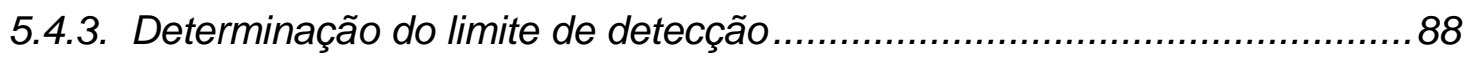

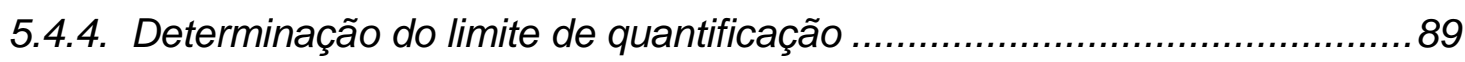

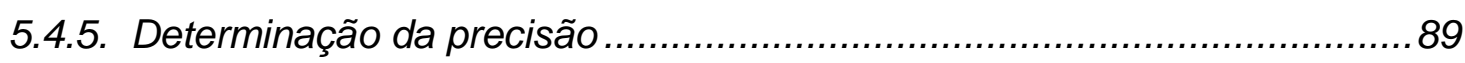

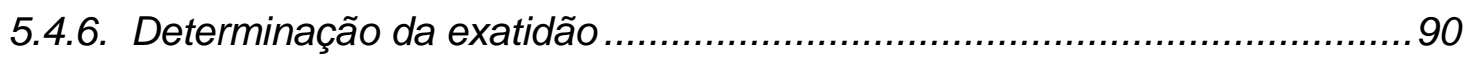

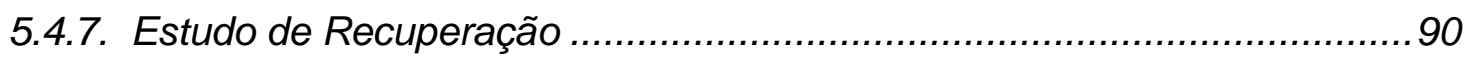

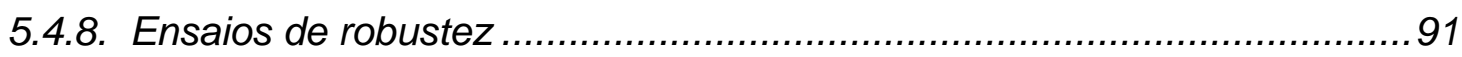

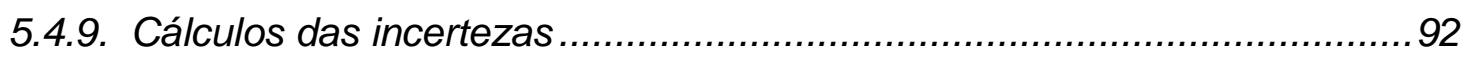

5.4.9.1. Incerteza associada à curva analítica .........................................92

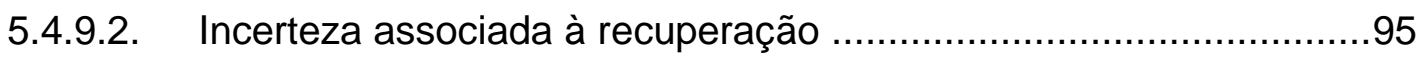

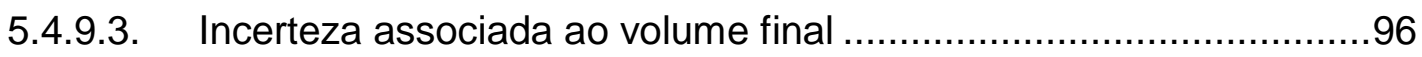

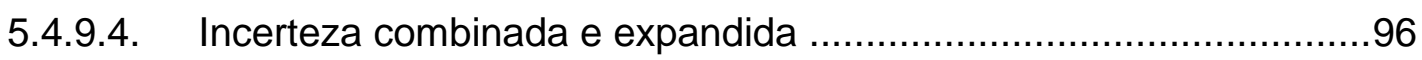

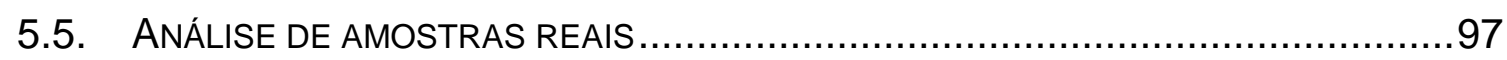

5.5.1. Coleta e preparação das amostras do rio Paraíba do Sul........................97

5.5.2. Outras aplicações da metodologia: avaliação de plastificantes em amostras de água mineral e mamadeira................................................ 99

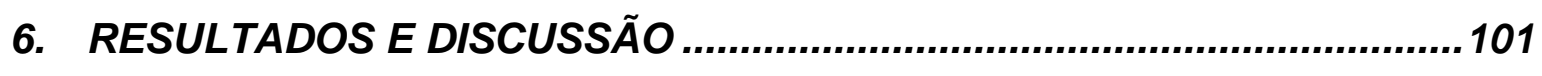

6.1. OtIMIZAÇÃO DA METODOLOGIA DE EXTRAÇÃO POR SPE ..............................101

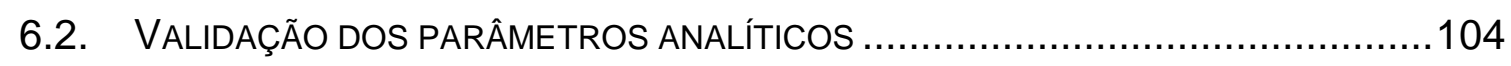

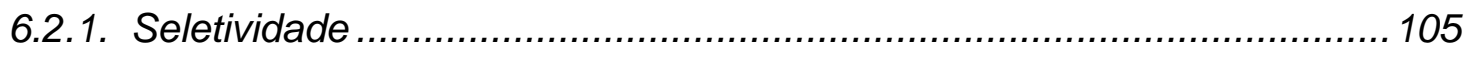

6.2.2. Linearidade e faixa linear de trabalho .................................................113

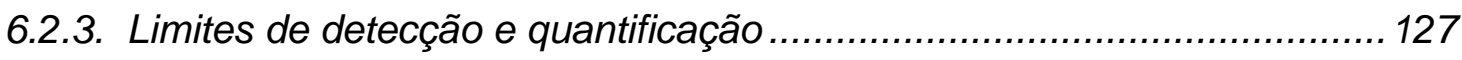




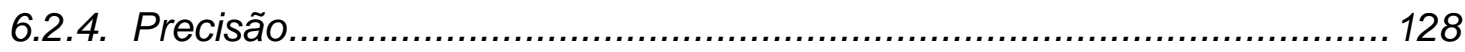

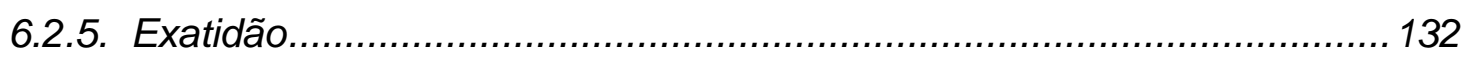

6.2.6. Estudos de recuperação ........................................................... 133

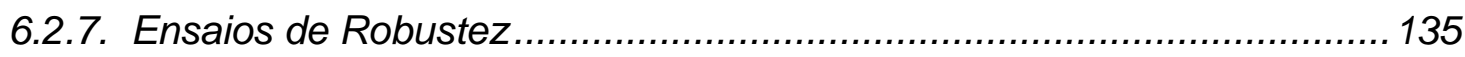

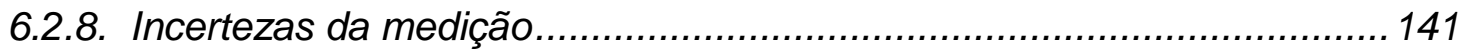

6.3. RESULTADO DOS BRANCOS .......................................................... 145

6.4. AvaliaçÃo dos XenOestrógenos nas ÁGUAS do RIO PARAíbA do SUL ......146

6.5. OUTRAS APLICAÇÕES DA METODOLOGIA ........................................... 153

6.5.1. Avaliação das amostras de água mineral .......................................... 153

6.5.2. Avaliação da resistência das mamadeiras ao aquecimento.................... 154

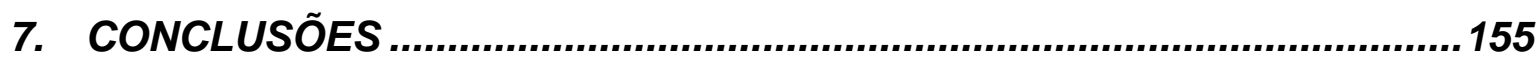

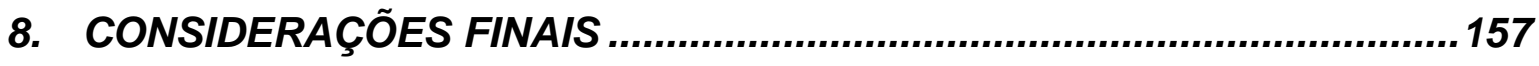

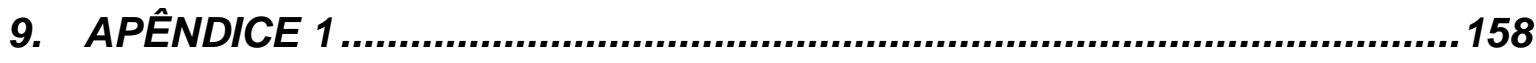

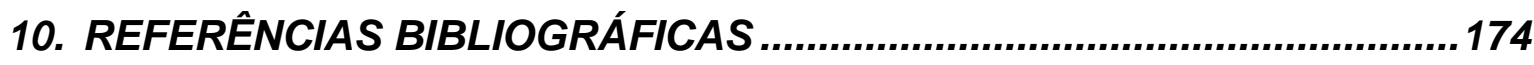




\section{LISTA DE TABELAS}

TABELA 1. Ações adotadas por entidades governamentais e não-governamentais sobre os disruptores endócrinos

TABELA 2. Concentrações máximas aceitáveis $\left(\mu g \cdot L^{-1}\right)$ em água potável (1) e água superficial (2) das legislações nacionais e internacionais

TABELA 3. Planejamento fatorial saturado para avaliação da estimativa do erro da distribuição dos efeitos utilizando o algoritmo de Dong (pequenos experimentos).

TABELA 4. Índices de coleta e tratamento de esgoto na região pertencente à bacia do Paraíba do Sul dos três municípios.

TABELA 5. Identificação dos seis padrões analíticos empregados no estudo ............... 75

TABELA 6. Testes de extração preliminares para definição da metodologia ................. 78

TABELA 7. Testes de extração para definição do método de extração ......................... 78

TABELA 8. Intervalo de monitoramento, tempos de retenção (TR) e relação massa/carga dos íons de cada composto monitorado no modo SIM ....... 82

TABELA 9. Concentrações das soluções de trabalhos dos seis compostos estudados 83

TABELA 10. Concentrações dos três níveis de fortificações ensaiadas para o estudo de recuperação.

TABELA 11. Parâmetros nominais e suas variações selecionadas para o ensaio de robustez

TABELA 12. Resultados da seletividade pela aplicação dos testes $F$ e $t$ para os compostos estudados, pela adição padrão somente nos solventes e na matriz de água tratada (AT). Tabela com os resultados dos valores calculados. Considerando $F_{\text {tabelado }}=4,28$ e $t_{\text {tabelado }}=2,179$.

TABELA 13. Resultados da seletividade pela aplicação dos testes $F$ e $t$ para os compostos estudados, pela adição padrão somente nos solventes e na matriz de água bruta $(A B)$. Tabela com os resultados dos valores calculados. Considerando $F_{\text {tabelado }}=4,28$ e $t_{\text {tabelado }}=2,179$.

TABELA 14. Valores de $t$ calculado obtidos para os testes de inclinação e paralelismo e do intercepto pela aplicação do teste t Student na matriz de água tratada, considerando os dois conjuntos de amostras com 7 graus de liberdade e $95 \%$ de confiança, onde 2,179 é o valor crítico....... 112

TABELA 15. Valores de $t$ calculado obtidos para os testes de inclinação e paralelismo e do intercepto pela aplicação do teste t Student na matriz de água bruta, considerando os dois conjuntos de amostra e 7 graus 
TABELA 16. Faixa de trabalho para cada composto, equação da reta e coeficiente de determinação $\left(r^{2}\right)$ obtidos pela adição padrão na matriz de água tratada (AT)

TABELA 17. Faixa de trabalho para cada composto, equação da reta e coeficiente de determinação $\left(r^{2}\right)$ obtidos pela adição padrão na matriz de água bruta $(A B)$

TABELA 18. Faixa de trabalho para cada composto, equação da reta e coeficiente de determinação $\left(r^{2}\right)$ obtidos pela adição padrão somente na solução de solventes

TABELA 19. Valores de $t$ calculado obtidos pelo teste t Student para a verificação do desvio da linearidade de cada ponto da curva para os seis compostos estudados na matriz de água tratada, onde $o$ valor de $t_{\text {tab }}=$ 2,365 considerando $7(n-1)$ graus de liberdade e 95\% de confiança.

TABELA 20. Valores de $t$ calculado obtidos pelo teste t Student para a verificação do desvio da linearidade de cada ponto da curva para os seis compostos estudados na matriz de água bruta, onde 0 valor de $t_{\text {tab }}=$ 2,365 considerando $7(n-1)$ graus de liberdade e 95\% de confiança.....

TABELA 21. Valores de $t$ calculado obtidos pelo teste t Student para a verificação do desvio da linearidade de cada ponto da curva para os seis compostos estudados no ensaio sem matriz, onde 0 valor de $t_{\text {tab }}=$ 2,365 considerando 7 (n-1) graus de liberdade e 95\% de confiança......

TABELA 22. Resultados resumidos da análise de variância (ANOVA) para os seis compostos estudados no ensaio com matriz de água tratada.

TABELA 23. Resultados resumidos da análise de variância (ANOVA) para os seis compostos estudados no ensaio com matriz de água bruta.

TABELA 24. Limite de detecção (LD) e limite de quantificação (LQ) para os seis compostos estudados na matriz de água tratada (AT) .

TABELA 25. Limite de detecção (LD) e limite de quantificação (LQ) para os seis compostos estudados na matriz de água bruta $(A B)$

TABELA 26. Limite de detecção (LD) e limite de quantificação (LQ) para os seis compostos estudados no ensaio sem matriz

TABELA 27. Coeficientes de variação (CV \%) para os compostos em três níveis de concentração no ensaio com matriz de água tratada.

TABELA 28. Coeficientes de variação (CV \%) para os compostos em três níveis de concentração no ensaio com matriz de água bruta.

TABELA 29. Valores do limite de repetitividade ( $r$ para os compostos em três níveis de concentração no ensaio com matriz de água tratada

TABELA 30. Valores do limite de repetitividade ( $r$ ) para os compostos em três níveis de concentração no ensaio com matriz de água bruta. 
TABELA 31. Valores do limite de reprodutibilidade (R) para os compostos em três níveis de concentração no ensaio com matriz de água tratada.

TABELA 32. Valores do limite de reprodutibilidade $(\mathrm{R})$ para os compostos em três níveis de concentração no ensaio com matriz de água bruta

TABELA 33. Resultados do índice z Score para os compostos estudados nos ensaios em matriz de água tratada (AT), água bruta e sem matriz

TABELA 34. Resultados dos estudos de recuperação na matriz de água tratada (AT) considerando três níveis de fortificação $(n=3)$

TABELA 35. Resultados dos estudos de recuperação na matriz de água bruta $(A B)$ considerando três níveis de fortificação $(n=3)$

TABELA 36. Incertezas expandidas para os xenoestrógenos estudados referentes ao ponto intermediário das curvas analíticas em água tratada (AT), considerando $\mathrm{k}=1,96$ e $95 \%$ de confiança

TABELA 37. Incertezas expandidas para os xenoestrógenos estudados referentes ao ponto intermediário das curvas analíticas em água bruta $(A B)$, considerando $\mathrm{k}=1,96$ e $95 \%$ de confiança

TABELA 38. Contribuição da incerteza de cada grandeza de entrada no cálculo do mensurando no ensaio em água tratada (AT), considerando o ponto médio do intervalo de concentração das curvas analíticas dos compostos estudados

TABELA 39. Contribuição da incerteza de cada grandeza de entrada no cálculo do mensurando no ensaio em água bruta $(A B)$, considerando o ponto médio do intervalo de concentração das curvas analíticas dos compostos estudados

TABELA 40. Resultados das análises da coleta de junho para as amostras de água tratada e água bruta dos quatro municípios da região do rio Paraíba do Sul

TABELA 41. Resultados das análises da coleta de setembro para as amostras de água tratada e água bruta dos quatro municípios da região do rio Paraíba do Sul....

TABELA 42. Resultados das análises da coleta de novembro para as amostras de água tratada e água bruta dos quatro municípios da região do rio Paraíba do Sul..... 


\section{LISTA DE FIGURAS}

FIGURA 1. Modos de interferência dos DEs no sistema endócrino. (a) resposta natural, (b) efeito agonista, (c) efeito antagonista

FIGURA 2. Estrutura química do dietilftalato e propriedades físico-químicas .............21

FIGURA 3. Estrutura química do dibutilftalato e propriedades físico-químicas ...........21

FIGURA 4. Estrutura química do nonilfenol e propriedades físico-químicas ...............24

FIGURA 5. Estrutura química do bisfenol A e propriedades físico-químicas ..............28

FIGURA 6. Estrutura química do pentaclorofenol e propriedades físico-químicas ...... 31

FIGURA 7. Estrutura química do benzo[a]pireno e propriedades físico-químicas....... 34

FIGURA 8. Esquema onde são esquematizadas as etapas da extração em fase

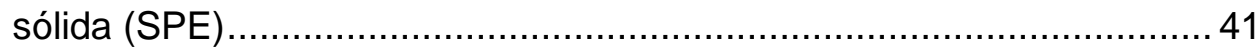

FIGURA 9. Etapas envolvidas no processo de estimativa de incerteza......................63

FIGURA 10. Diagrama de Causa e Efeito da metodologia desenvolvida para análise de xenoestrógenos em água.....

FIGURA 11. Unidades de Gerenciamento de Recursos Hídricos do estado de São Paulo

FIGURA 12. Área de abrangência da Bacia hidrográfica do rio Paraíba do Sul.

FIGURA 13. Divisão territorial dos municípios localizados no trecho paulista da bacia hidrográfica do rio Paraíba do Sul, em destaque os quatro municípios de interesse

FIGURA 14. Sistema de extração em fase sólida utilizado para concentração dos analitos, e bomba a vácuo .

FIGURA 15. Fluxograma das etapas para extração e análise dos analitos por SPEGC/MS.

FIGURA 16. Programação da temperatura definida no GC/MS

FIGURA 17. Balanço hídrico semanal do ano de 2010, e em destaque as datas das campanhas amostrais

FIGURA 18. Ponto de amostragem na ETA da cidade de Guararema

FIGURA 19. Coleta das amostras de água tratada (esq.) e bruta (dir.) em frascos de vidro âmbar na ETA de Guararema

FIGURA 20. Comparação das áreas dos picos cromatográficos dos seis composto estudados com a área dos picos da solução padrão mix.

FIGURA 21. Comparação das porcentagens de recuperação obtidas pelos testes de extração 6 a 11. As linhas vermelhas indicam o valor mínimo (70\%) e máximo (120\%) aceitos para análise de resíduos. 
FIGURA 22. Cromatograma da solução mix dos compostos estudados (DEP, dietilftalato; NP, nonilfenol; PCP, pentaclorofenol; DBP; dibutilftalato; $\mathrm{BPA}$, bisfenol $\mathrm{A} ; \mathrm{B}[\mathrm{a}] \mathrm{P}$, benzo[a]pireno) na matriz de água tratada referente ao segundo ponto da curva analítica obtido no modo SIM ...... 105

FIGURA 23. Cromatograma da solução mix dos compostos estudados (DEP, dietilftalato; NP, nonilfenol; PCP, pentaclorofenol; DBP; dibutilftalato; BPA, bisfenol $\mathrm{A}$; $\mathrm{B}[\mathrm{a}] \mathrm{P}$, benzo[a]pireno) na matriz de água bruta referente ao segundo ponto da curva analítica obtido no modo SIM ...... 105

FIGURA 24. Picos cromatográficos dos compostos estudados obtidos no modo SIM, em detalhe à esquerda os íons monitorado

FIGURA 25. Gráficos da seletividade representados pelas retas obtidas nos ensaios com água tratada, água bruta e sem matriz

FIGURA 26. Representação gráfica da linearidade para os seis xenoestrógenos estudados na matriz de água tratada.

FIGURA 27. Representação gráfica da linearidade para os seis xenoestrógenos estudados na matriz de água bruta

FIGURA 28. Representação gráfica da linearidade para os seis xenoestrógenos estudados no ensaio sem matriz

FIGURA 29. Gráficos dos resíduos absolutos (a) e normalizados (b) para os compostos dietilftalato e dibutilftalato no ensaio com matriz de água tratada (AT)

FIGURA 30. Gráficos dos resíduos absolutos (a) e normalizados (b) para os compostos nonilfenol, pentaclorofenol, bisfenol A e benzo[a]pireno no ensaio com matriz de água tratada (AT)

FIGURA 31. Gráficos dos resíduos absolutos (a) e normalizados (b) para os compostos dietilftalato, dibutilftalato, nonilfenol e pentaclorofenol no ensaio com matriz de água bruta $(A B)$

FIGURA 32. Gráficos dos resíduos absolutos (a) e normalizados (b) para os compostos bisfenol $A$ e benzo[a]pireno no ensaio com matriz de água bruta $(A B)$

FIGURA 33. Gráficos dos resíduos absolutos (a) e normalizados (b) para os compostos dietilftalato e dibutilftalato no ensaio sem matriz

FIGURA 34. Gráficos dos resíduos absolutos (a) e normalizados (b) para os compostos nonilfenol, pentaclorofenol, bisfenol A e benzo[a]pireno no ensaio sem matriz.

FIGURA 35. Gráficos da faixa de intervalo de confiança no ensaio sem matriz para os seis compostos estudados na faixa de trabalho considerada.

FIGURA 36. Representação gráfica do teste de verificação de significância dos efeitos no ensaio de robustez em água tratada (AT)

FIGURA 37. Gráficos de probabilidade normal (esquerda) e meia-normal (direita) do ensaio de robustez em água tratada (AT) para os compostos dietilftalato, dibutilftalato e nonilfenol. 
FIGURA 38. Gráficos de probabilidade normal (esquerda) e meia-normal (direita) do ensaio de robustez em água tratada (AT) para os compostos pentaclorofenol, bisfenol $A$ e benzo[a]pireno

FIGURA 39. Representação gráfica do teste de verificação de significância dos efeitos no ensaio de robustez em água bruta

FIGURA 40. Gráficos de probabilidade normal (esquerda) e meia-normal (direita) do ensaio de robustez em água bruta $(\mathrm{AB})$ para os compostos dietilftalato, dibutilftalato e nonilfenol

FIGURA 41. Gráficos de probabilidade normal (esquerda) e meia-normal (direita) do ensaio de robustez em água bruta $(A B)$ para os compostos pentaclorofenol, bisfenol A e benzo[a]pireno

FIGURA 42. Representações gráficas das incertezas individuais envolvidas na análise dos xenoestrógenos na matriz de água tratada (AT)

FIGURA 43. Representações gráficas das incertezas individuais envolvidas na análise dos xenoestrógenos na matriz de água bruta $(A B)$

FIGURA 44. Concentrações do composto dietilftalato nos três meses de coleta nas amostras de água tratada (a) e água bruta (b)

FIGURA 45. Concentrações dos compostos dibutilftalato e nonilfenol nas amostras de água tratada $(A T)$ e água bruta $(A B)$ nos municípios de Taubaté e São José dos Campos 


\section{LISTA DE ABREVIATURAS}

AGEVAP Agência da Bacia do Rio Paraíba do Sul

ANOVA Analysis of variance (Análise de variância)

ANVISA Agência Nacional de Vigilância Sanitária

APCI Atmospheric pressure chemical ionization (ionização química à pressão atmosférica)

APEs Alquilfenóis etoxilados

APPI Atmospheric pressure photo ionization (Fotoionização à pressão atmosférica)

B[a]P Benzo[a]pireno

BPA Bisfenol A

CAS Chemical Abstract Service

CEIVAP Comitê de Integração da Bacia Hidrográfica do Rio Paraíba do Sul

CETESB Companhia Ambiental do Estado de São Paulo

Cl Chemical ionization (Ionização química)

CIIAGRO Centro Integrado de Informações Agrometeorológicas

CONAMA Conselho Nacional do Meio Ambientes

DBP Dibutilftalato

DCM Diclorometano

DEP Dietilftalato

DEs Disruptores endócrinos

DES Dietilestilbestrol

DDT Diclorodifeniltricloroetano

DNA Ácido desoxirribonucléico

DPR Desvio padrão relativo

ECD Electron capture detector (Detector por captura de elétrons)

El Electron impact (Ionização por elétrons)

ETA Estação de Tratamento de Água

ETE Estação de Tratamento de Esgoto

EtOAc Acetato de Etila

ESI Electrospray ionization (Ionização por electrospray) 
FAB Fast atom bombardment (Ionização por átomos rápidos)

FID Flame ionization detector (Detector por ionização em chamas)

GC Gas chromatography (cromatografia gasosa)

GC/MS Gas chromatography with mass spectrometry (Cromatógrafo gasosa acoplado ao espectrômetro de massas)

HCB Hexaclorobenzeno

HCH Hexaclorociclohexano

HPA Hidrocarboneto policíclico aromático

HPLC High Performance Liquid Chromatography (Cromatografia de Alta Eficiência)

IBGE Instituto Brasileiro de Geografia e Estatística

ICH International Conference on Harmonization (Conferência Internacional em Harmonização)

INMETRO Instituto Nacional de Metrologia, Normalização e Qualidade Industrial

ISO International Organization for Standardization (Organização Internacional para Padronização)

IPCS International Programme on Chemical Safety (Programa Internacional de Segurança Química)

IUPAC International Union of Pure and Applied Chemistry (União Internacional de Química Pura e Aplicada)

LC Liquid chromatography (cromatografia líquida)

LD Limite de detecção

LC/MS Liquid chromatography with mass spectrometry (Cromatógrafo líquido acoplado ao espectrômetro de massas)

LME Limite de Migração Específico

LQ Limite de quantificação

MALDI Matrix-assisted laser dessorption ionization (Ionização por dessorção a laser assistida pela matriz)

ME margin of error (margem de erro)

$\mathrm{MeOH} \quad$ Metanol

MS

Mass spectrometry (espectrometria de massas)

NP Nonilfenol

NPEs Nonilfenóis etoxilados

OEDC Organization for Economic Co-operation and Development (Organização para Cooperação e Desenvolvimento Econômico)

OMS Organização Mundial de Saúde

OSPAR Oslo and Paris Commission (Comissão de Paris e Oslo) 
PBDEs Polibromos difenil éteres

PCBs Bifenilas policloradas

PCP Pentaclorofenol

PET Polietileno tereftalato

PNEC Predicted No Effect Concentrations (Concentração sem efeito previsível)

POPs Poluentes Orgâncios Persistentes

PVC Policloreto de vinila

REACH Registration, Evaluation, Authorisation and Restriction of Chemical substances

SABESP Companhia de saneamento Básico do Estado de São Paulo

SETAC Society of Environmental Toxicology and Chemistry (Sociedade de toxicologia Ambiental e Química)

SDME Single-drop microextraction (Microextração com gota única)

SIM Select ion monitoring (Monitoramento seletivo de íons)

SME Simultaneous margin of error (margem simultânea de erro)

SPE Solid phase extraction (extração em fase sólida)

SPME Solid-phase microextraction (microextração em fase sólida)

STP Substâncias Tóxicas Persistentes

TBT Tributilestanho

TOF Time-of-flight (Tempo de vôo)

TSP Thermo-spray ionization (Ionização por spray aquecido)

UGRHI Unidade de Gerenciamento de Recursos Hídricos

UKEA United Kingdom Environment Agency (Agência Ambiental do Reino Unido)

UNEP United Nations Environment Programme (Programa das Nações Unidas para o Meio Ambiente)

UPLC Ultra Performance Liquid Chromatography (Cromatografia Líquida de Ultra Eficiência)

USEPA United States Environmental Protection Agency (Agência de Proteção Ambiental dos Estados Unidos)

VMPs Valores máximos permissíveis

WWF World Wildlife Foundation (Fundo Mundial para a Natureza) 


\section{INTRODUÇÃO}

A produção comercial de substâncias químicas sintetizadas pelo Homem iniciou-se na década de 1920. Entretanto, foi após a Segunda Guerra Mundial, com o anseio por novas tecnologias e desenvolvimento industrial, que a produção, o uso e o lançamento de compostos orgânicos sintéticos no meio ambiente aumentaram drasticamente. Grande parte dessas substâncias foi produzida com 0 intuito de suprir a demanda da população por alimentos e melhorar a qualidade das culturas. Os defensivos agrícolas, como o HCB (hexaclorobenzeno), $\mathrm{HCH}$ (hexaclorociclohexano) e 0 DDT (diclorodifeniltricloroetano), foram usados em ampla escala nos anos que permearam esse período da história mundial (Colborn et al., 1993; Reys, 2001; El Shahawi et al., 2010).

Os avanços da química orgânica beneficiaram a espécie humana em diversos aspectos, principalmente em relação a sua qualidade de vida. Todavia, o descaso com a avaliação da segurança destas substâncias para a saúde do meio ambiente e dos seres humanos, trouxe problemas no âmbito ambiental que só foram conhecidos e discutidos nas últimas décadas, como a degradação dos recursos naturais, entre eles da água, na esfera local, regional e global.

A preocupação crescente com a disponibilidade dos recursos hídricos justifica-se pelo fato de a água desempenhar papel fundamental no desenvolvimento social e econômico da humanidade, além de ser um bem essencial à vida. Disponibilidade essa que é afetada não apenas pela escassez da água em algumas regiões, ou pelo aumento da demanda mundial, mas também pela depreciação de sua qualidade. Em função do crescimento desordenado das cidades e das atividades antrópicas no entorno das bacias hidrográficas, é notório o aumento da poluição das águas superficiais e subterrâneas (Dias e Barros, 2007; Tundisi, 2008; Rebouças, 2001). 
São diversos os agentes que podem impactar a qualidade dos corpos hídricos - matéria orgânica; nutrientes, como nitrogênio e fósforo, responsáveis pelo fenômeno da eutrofização em muitos mananciais; compostos inorgânicos, como os metais tóxicos; e compostos orgânicos, agrotóxicos e poluentes orgânicos persistentes (POPs), por exemplo, que oferecem riscos à saúde dos seres vivos. A poluição do ambiente aquático ocorre principalmente em virtude da urbanização, industrialização e expansão agrícola, podendo as fontes poluidoras serem classificadas em cargas pontuais, por descarga de efluentes domésticos e industriais ou por acidentes ambientais, ou cargas difusas, no caso de escoamento de áreas urbanas e rurais (Fernandes Neto e Ferreira, 2007; Santos et al., 2007; Tucci et al., 2001).

Apesar de nos últimos anos ser observado um aumento por parte das empresas de saneamento nos investimentos de redes coletoras de esgoto e estações de tratamento, do volume total de efluentes doméstico e industrial gerado pelos municípios brasileiros, apenas uma pequena parte é efetivamente tratada antes de ser descartada nos corpos receptores. Dessa forma, a falta de saneamento adequado é a principal fonte de poluição dos corpos d'água, e compromete um dos usos prioritários deste recurso, o abastecimento público, fazendo com que se busquem fontes de captação mais distantes e com que os tratamentos químicos aplicados para tornar a água potável sejam cada vez mais complexos e dispendiosos (Tucci, 2008; Diniz, 2006).

A introdução constante de uma ampla gama de contaminantes orgânicos e inorgânicos nos corpos hídricos, e os efeitos dessas substâncias sobre a saúde ambiental e pública, constitui atualmente o principal desafio do poder público para garantir a qualidade das águas superficiais e das destinadas ao consumo humano. A Resolução $n^{\circ} 357$, de 2005 , do Conselho Nacional do Meio Ambiente - CONAMA estabelece as diretrizes ambientais para o enquadramento e classificação dos corpos d'água e dispõe sobre os padrões de lançamento de efluentes. O controle e vigilância da qualidade da água para abastecimento da população, assim como os padrões de potabilidade, são definidos pela Portaria n 518 de 2004 do Ministério da Saúde (Fernandes Neto e Ferreira, 2007; Brasil, 2005a; Brasil, 2005b). 
Embora, as espécies químicas e os valores máximos permissíveis (VMPs) presentes na Portaria 518/04 tenham sido estabelecidos tendo como base as leis internacionais e as orientações da Organização Mundial da Saúde - OMS, alguns autores questionam a necessidade de avaliação e revisão da legislação vigente devido aos avanços do conhecimento científico e dos novos guias publicados pela OMS. O que corrobora para a necessidade de atualização da legislação nacional é o fato de que os processos convencionais de tratamento de água e esgoto não conseguem remover em sua totalidade substâncias prejudiciais aos organismos, como alguns compostos classificados como disruptores endócrinos, que podem estar presentes em nossas águas, mas não são abrangidos pelas leis vigentes (Fernandes Neto e Ferreira, 2007; Bila e Dezotti, 2007).

Substâncias naturais ou sintéticas com capacidade de alterar o funcionamento do sistema hormonal de animais e seres humanos mesmo quando presentes em concentrações traço ( $\mu \mathrm{g} \cdot \mathrm{L}^{-1}$ ou ng. $\mathrm{L}^{-1}$ ), os chamados disruptores endócrinos, têm recebido especial atenção nas últimas décadas por parte da comunidade científica, de órgãos governamentais e de outros atores da sociedade. A Agência de Proteção Ambiental dos Estados Unidos (United States Environmental Protection Agency, USEPA) define um composto disruptor endócrino como "um agente exógeno que interfere na síntese, secreção, transporte, metabolismo, ligação ou eliminação dos hormônios naturais do corpo, os quais são responsáveis pela manutenção da homeostase e regulação do processo de reprodução, desenvolvimento e/ou comportamento" (Lintelmann et al., 2003; Reis filho et al., 2006; USEPA, 1998).

O grupo de moléculas classificadas como disruptores endócrinos é altamente heterogêneo, e inclui substâncias naturais - hormônios femininos (estrógenos) e masculinos (andrógenos), ou ainda os fitoesteróides, e as substâncias sintéticas, que podem ter utilização agrícola (agrotóxicos), industrial, como matéria-prima ou subproduto (plastificantes, alquilfenóis, bifenilas, dioxinas, hidrocarbonetos policíclicos aromáticos - HPAs), ou farmacêutica (estrógenos sintéticos, antitérmicos, antibióticos, antiinflamatórios). Esses compostos estão presentes em grande quantidade nos bens de consumo da sociedade 
contemporânea, seja direta ou indiretamente, e a exposição humana a estes interferentes hormonais pode ocorrer por meio da ingestão de alimentos contaminados, consumo de água, vias respiratórias ou contato com o solo. Fetos e embriões também podem ser severamente afetados por estes agentes químicos, pois ao bioacumularem-se nos organismos das fêmeas alguns disruptores ultrapassam a barreira placentária ou são transferidos pelo leite materno (Bila e Dezotti, 2007; Diamanti-Kandarakis et al., 2009; Reys, 2001).

Por apresentarem estruturas químicas distintas, o comportamento destes compostos no meio ambiente também é divergente. Muitos dos produtos químicos industriais são considerados poluentes orgânicos persistentes (POPs), e por permanecerem no ambiente por grande período de tempo podem ser transportados por longas distâncias, o que faz com que sejam encontrados em todas as regiões do planeta, além de serem bioacumuláveis nos níveis tróficos em função da característica lipofílica. Outros compostos sofrem degradação ambiental facilmente ou são metabolizados pelo nosso organismo de forma rápida, como os estrógenos naturais ou fármacos, porém, a introdução destes disruptores no ambiente é contínua (Duarte, 2008; Damstra et al., 2002; Reis filho et al., 2006).

É crescente o número de publicações internacionais que têm como objetivo investigar a presença de disruptores endócrinos associados a atividades industriais, e que são foco deste estudo - ftalatos, alquifenóis, bisfenol A e HPAs, em amostras ambientais aquosas, como águas superficiais, de abastecimento e subterrâneas, águas marinhas e efluentes (Azevedo et al., 2001; Liu et al., 2004; Serôdio e Nogueira, 2006; Gibson et al., 2007; Rezaee et al., 2009; Sánchez-Avila et al., 2009). No Brasil, os estudos conduzidos sobre disruptores sintéticos datam do início da década, sendo que grande parte foram desenvolvidos na região sudeste do país (Loureiro, 2002; Leandro, 2006; Ghiselli, 2006; Raimundo, 2007; Gerolin 2008; Moreira et al., 2009; Sodré et al., 2010).

$\mathrm{Na}$ área de estudo abordada por esta pesquisa, a bacia hidrográfica do rio Paraíba do Sul, foram realizadas, até o momento, duas avaliações da qualidade das águas quanto à presença de compostos esteróides (Kuster et al., 
2009; Otomo, 2010). Todavia, o estudo realizado por Kuster et al. (2009) abrangeu a parte fluminense da bacia. Dessa forma a avaliação da qualidade da água superficial e de distribuição quanto à presença de disruptores endócrinos de origem industrial nos municípios de Guararema, São José dos Campos, Taubaté e Pindamonhangaba, pertencentes ao lado paulista da bacia do rio Paraíba do Sul, torna-se de extrema importância, pois permitirá conhecer os níveis de contaminação da referida região. Outro fator motivador desta pesquisa foi a parceria estabelecida entre o IPEN e a Companhia de Saneamento Básico do Estado de São Paulo (SABESP).

Compreendido entre os estados de Minas Gerais (37,5\%), São Paulo $(24,5 \%)$ e Rio de Janeiro (38\%), a bacia hidrográfica do Paraíba do Sul possui uma área de aproximadamente, $55.400 \mathrm{~km}^{2}$. Embora localizada em área de Mata Atlântica, a vegetação característica remanescente representa apenas $11 \%$ do total, sendo restrita a regiões elevadas e de relevo acidentado ou unidades de conservação. Grande parte desta devastação pode ser atribuída à ocupação humana. A agropecuária e a atividade industrial são as maiores fontes da economia, entretanto o maior setor consumidor de água é o agrícola. Em função do grande parque industrial (em 2002 eram 2500 empresas registradas na CETESB apenas na parte paulista da bacia), crescimento desordenado das cidades e falta de saneamento básico, é perceptível a deterioração da qualidade das águas do rio Paraíba do Sul e diminuição da sua disponibilidade hídrica (Gruben et al., 2002).

A análise de micropoluentes em amostras ambientais constitui um desafio pela complexidade das matrizes, baixas concentrações dos compostos alvo no ambiente, e necessidade de métodos cada vez mais sensíveis e precisos. Sendo assim, diversos métodos analíticos são utilizados para determinação dos disruptores em água. Dentre as técnicas de preparação de amostras, a extração em fase sólida (SPE, solid phase extraction) ganha destaque entre as demais pela rapidez, seletividade e bons níveis de recuperação. As técnicas de cromatografia gasosa (GC, gas chromatography) e cromatografia líquida (LC, liquid chromatography), usadas na determinação dos analitos, podem ser acopladas a diferentes detectores, entretanto, o detector por espectrometria de 
massas (MS, mass spectrometry) se sobrepõe por apresentar alta seletividade e sensibilidade (Petrovic et al., 2002; Richardson, 2009). Nesta pesquisa, utilizou-se um equipamento de cromatografia gasosa com detecção por espectrometria de massas, que continua sendo a técnica mais amplamente utilizada na análise dos xenoestrógenos investigados por não necessitarem da etapa de derivatização (Ying, 2007). Segundo Mansilha et al. (2010) a combinação das técnicas de SPE e GC/MS é tida como uma das mais eficientes para a separação, identificação e quantificação de disruptores endócrinos, mesmo na faixa de nanograma.

Porém não são suficientes apenas boas técnicas analíticas para garantir a qualidade dos dados gerados e a confiabilidade dos resultados. Visando atender as exigências de órgãos nacionais e internacionais o novo método deve passar pelo processo denominado de validação de ensaio químico. A validação busca demonstrar que a metodologia desenvolvida é adequada ao uso pretendido, além de assegurar a comparabilidade e rastreabilidade dos resultados. Apesar de não existir uma norma que padronize o processo de validação, no Brasil, as duas agências que regulamentam e fornecem guias para validar um ensaio são a ANVISA - Agência Nacional de Vigilância Sanitária e o INMETRO - Instituto Nacional de Metrologia, Normalização e Qualidade Industrial (Brito et al., 2009; Brasil, 2003; INMETRO, 2010).

É grande o volume de experimentos laboratoriais e cálculos estatísticos para demonstrar a qualidade das medidas instrumentais envolvidas na validação de um método analítico, portanto, neste estudo, que visou determinar seis disruptores endócrinos de origem industrial em amostra de água de municípios do Vale do Paraíba, utilizando a técnica de extração em fase sólida (SPE) seguida de determinação por cromatografia gasosa com detecção por espectrometria de massas (GC/MS), utilizou-se a planilha "Validação de Ensaios Químicos", desenvolvida por Furusawa (2007), a qual é baseada no documento DOQCGCRE-8 (INMETRO, 2003) como ferramenta estatística para a avaliação dos parâmetros de desempenho da metodologia proposta. 


\section{OBJETIVO}

Este estudo teve como foco desenvolver e validar metodologia analítica para determinação de compostos com ação disruptora endócrina provenientes de atividades antropogênicas em amostras de água bruta e água tratada da região da bacia hidrográfica do rio Paraíba do Sul.

\subsection{OBjetivos específicos}

- Desenvolver, adaptar e otimizar metodologia analítica para a extração e quantificação de 6 compostos orgânicos - dietilftalato, dibutilftalato, nonilfenol, bisfenol A, pentaclorofenol e benzo[a]pireno - utilizando a técnica de extração em fase sólida (SPE) e determinação por cromatografia gasosa acoplada à espectrometria de massas (GC/MS);

- Validar a metodologia desenvolvida, demonstrando a qualidade dos dados gerados;

- Aplicar a metodologia desenvolvida em amostras de água bruta e tratada provenientes de Estações de Tratamento de Água de quatro municípios do Vale do Paraíba paulista, a fim de identificar e quantificar as substâncias presentes. 


\section{REVISÃO DE LITERATURA}

\subsection{Produção de SUBSTÂNCIAS QUímiCAS PELA SOCIEDADE MOdERNA}

Embora a produção comercial de substâncias orgânicas sintetizadas pelo homem tenha iniciado no começo do século XX, a produção e a utilização de produtos químicos datam das primeiras civilizações humanas, e na atualidade, estão presentes em todos os campos de nossas vidas (El Shahawi et al., 2010; Ramlogan, 1997).

A Revolução Industrial, em meados de 1800, é dada como o marco entre o desenvolvimento humano e a degradação do meio ambiente. Juntamente com a evolução no processo produtivo ocorreu o crescimento populacional, com consequente aumento na demanda agrícola e nas áreas urbanas, e maior consumismo. Outro fato marcante para o aumento na introdução de compostos químicos artificiais no ambiente ocorreu após a Segunda Guerra Mundial, pelo desejo de impulsionar o desenvolvimento das indústrias, proteger a saúde pública e produzir mais e melhores culturas (Ramlogan, 1997; El Shahawi et al., 2010).

Segundo o programa REACH da União Européia (REACH, 2011), a produção de substâncias químicas aumentou de 1 milhão de toneladas nos anos de 1930 para 400 milhões de toneladas no início do século XXI. O REACH (Registration, Evaluation, Authorisation and Restriction of Chemical substances) é uma regulamentação da União Européia instituída em 2007, e que tem como objetivo promover a proteção da saúde humana e do meio ambiente, além de aumentar a inovação e a competitividade das indústrias européias. Mais de 100.000 substâncias são conhecidas na Europa, das quais entre 30 e 70 mil têm utilização diária (REACH, 2011; Schwarzenbach et al., 2006).

Na pesquisa realizada no início de 2011, a divisão da Sociedade Química Americana - Chemical Abstract Service (CAS) apresentava registradas 
quase 57 milhões de substâncias orgânicas e inorgânicas (CAS, 2011). Estima-se que desde a década de 1980, 6 mil novas formulações são criadas semanalmente, e que cerca de 3 mil substâncias químicas são adicionadas em alimentos, 700 podem ser encontradas na água potável e 400 já foram identificadas em tecidos humanos (Ramlogan, 1997).

É inquestionável a importância dos compostos químicos no desenvolvimento social e econômico da sociedade e na melhora do bem estar do ser humano. Todavia, o destino final dessas substâncias, quer sejam elas utilizadas na fabricação de bens de consumo, em alimentos ou como fármacos, são os compartimentos ambientais (solo, ar, água e sedimentos). Segundo Schwarzenbach e colaboradores (2006), cerca de 300 milhões de toneladas de produtos químicos sintéticos anualmente empregados na indústria e em produtos de consumo tem como parte de seus caminhos as águas naturais.

De acordo com Binetti et al. (2008), o estudo divulgado em 1982 pela Academia Nacional de Ciências mostrou que nos EUA apenas 22\% das substâncias químicas com alto volume de produção (produção maior que 1 milhão de toneladas/ano) tinham dados míninos de toxicidade avaliados (que incluem testes de toxicidade aguda e crônica, toxicidade sobre a reprodução e desenvolvimento, e mutagenicidade). Em 1998, apenas 7\% dos compostos produzidos ou importados em alta escala tinham dados toxicológicos completos, e para $43 \%$ deles, nenhuma informação estava disponível.

O relatório da Europeans Chemicals Bureau de 1999, apontou que na União Européia apenas 3\% das substâncias com produção superior a 1 milhão de toneladas por ano possuíam dados toxicológicos completos, incluindo ensaios toxicológicos de longa exposição, comportamento em vários compartimentos ambientais e toxicologia para mamíferos. 65\% apresentavam algum dado, porém menos do que as informações consideradas básicas, e que para $21 \%$ das substâncias não existia nenhum dado toxicológico (Binetti et al., 2008; Lyons et al., 2000). 


\subsection{DISRUPTORES ENDÓCRINOS: HISTÓRICO E EVIDÊNCIAS DE DISFUNÇÃO}

Disruptores endócrinos (DEs) são substâncias naturais ou artificiais, que podem interferir negativamente no funcionamento do sistema endócrino de animais e de seres humanos, alterando funções de desenvolvimento, reprodução, comportamento e homeostasia (equilíbrio interno) dos organismos. Existem muitas evidências de que estes compostos possam causar efeitos adversos na saúde humana, como aumento na incidência de câncer de mama, próstata e testículo, anomalias no sistema reprodutor, diminuição na contagem de espermatozóides, e disfunções tireoidianas. Em animais foi observado que a exposição ambiental dos organismos a alguns compostos químicos levou a problemas de reprodução e desenvolvimento em várias espécies de aves, peixes, répteis e mamíferos (CEC, 1999; Damstra et al., 2002; Lintelmann et al., 2003; Bila e Dezotti, 2007).

A Agência de Proteção Ambiental dos Estados Unidos (United States Environmental Protection Agency, USEPA) define um composto disruptor endócrino como "um agente exógeno que interfere na síntese, secreção, transporte, metabolismo, ligação ou eliminação dos hormônios naturais do corpo, os quais são responsáveis pela homeostase, reprodução, desenvolvimento e/ou comportamento". Já o Programa Internacional de Segurança Química (International Programme on Chemical Safety, IPCS), juntamente com o Canadá, o Japão, os Estados Unidos, a OEDC (Organization for Economic Co-operation and Development) e a União Européia, utiliza uma definição mais abrangente, e entende que um disruptor endócrino seja "uma substância ou uma mistura de substâncias exógenas que alteram uma ou várias funções do sistema endócrino e, conseqüentemente, causam efeitos adversos sobre a saúde de um organismo intacto, sua descendência, e/ou (sub) populações" (USEPA, 1998; CEC, 1999).

Embora o interesse da comunidade científica por esta importante questão ambiental tenha sido despertado há poucas décadas atrás, o conhecimento sobre a capacidade de substâncias naturais ou sintéticas de 
mimetizarem hormônios, e que hoje podem ser classificados como interferentes endócrinos, data do início do século XX (Bila e Dezotti, 2007; Matthiessen, 2003).

Em um dos estudos pioneiros, Allen e Doisy (1924), induziram à maturidade sexual ratas jovens por meio da injeção de "hormônio folicular" de porcas. No final de década de 1930, a atividade estrogênica de compostos que continham um anel fenantreno já era conhecida (Cook et al., 1933). Publicada em 1938, uma pesquisa investigou a estrutura e o potencial estrogênico de uma extensa lista de compostos. Os autores concluíram que mesmo não apresentando um núcleo fenantreno, compostos bifenólicos e alquilfenóis (como o bisfenol A e o nonilfenol) apresentavam uma fraca atividade estrogênica, porém, capaz de produzir efeitos em animais de laboratório (Dodds e Lawson, 1938; Sumpter, 1998).

Neste mesmo ano, o autor da pesquisa, Edward Charles Dodds e colaboradores, anunciaram a síntese de um hormônio sintético que mimetizava o estrógeno natural, o dietilestilbestrol, ou DES. Essa droga foi prescrita para quase 5 milhões de mulheres grávidas entre os anos de 1948 e 1971 em todo o mundo antes de seu uso ser banido em 1970. Inicialmente o DES foi indicado como um antiabortivo, mas seu uso foi ampliado para mulheres sem histórico de abortos ou partos prematuros, com a justificativa de que o químico sintético tornaria o bebê mais saudável (Colborn et al. 2002; Colborn et al. 1993).

Anos mais tarde, descobriu-se que as filhas nascidas de mulheres que tomaram o DES, aparentemente normais, sofriam de malformações no sistema reprodutor, redução da fertilidade, gestações anormais, desordens no sistema imunológico e algumas apresentavam um tipo raro de câncer vaginal. Apesar de não serem conclusivos, estudos científicos indicam que os meninos, cujas mães também utilizaram o DES, apresentam problemas de fertilidade e índices mais elevados de câncer testicular. Os efeitos colaterais do DES haviam sido preconizados em ensaios de laboratório realizados com ratos machos e fêmeas, entretanto, estes resultados só foram levados em conta anos mais tarde, quando as anomalias no sistema reprodutor foram evidenciadas em seres humanos que atingiam a puberdade (Bila e Dezotti, 2007; Birkett e Lester, 2003). 
No mesmo ano em que foi anunciada a síntese do DES, o químico suíço Paul Müller descobriu as propriedades de um pesticida poderoso, o DDT (diclorodifeniltricloroetano), o que Ihe rendeu o prêmio Nobel em 1948. O DDT é um inseticida muito persistente no meio ambiente e foi amplamente utilizado no período pós-guerra, entre os anos de 1950 e 1960. Concomitantemente ao seu uso, pesquisas mostraram os efeitos estrogênicos do DDT sobre mamíferos e pássaros. Em um estudo publicado em 1950, Burlington e Linderman, observaram que quando administrado DDT a galos jovens, estes apresentavam sinais de feminização, como diminuição dos testículos e não crescimento das cristas (Bila e Dezotti, 2007; Colborn et al., 2002).

Em 1962, o lançamento do livro "Primavera Silenciosa" de Rachel Carson chamou atenção sobre os riscos da utilização de pesticidas na agricultura em função dos danos causados por estes compostos na reprodução de aves. Nesta mesma obra relatou-se a ligação entre a contaminação do meio ambiente pelo composto DDT e a diminuição das populações de algumas espécies de animais. A aplicação deste inseticida foi proibida nos anos de 1970 em função das evidências de disfunção endócrina, como as anomalias nos sistemas reprodutores de jacarés em lagos da Flórida contaminados com DDT. Todavia, atualmente alguns países menos desenvolvidos ainda utilizam este pesticida para combater os vetores da malária (Birkett e Lester, 2003; Lintelmann et al., 2003).

Entre os anos de 1960 e 1990 vários trabalhos publicados deixavam claro que uma infinidade de substâncias químicas que estavam presentes no meio ambiente eram capazes de causar alterações no sistema hormonal de animais mesmo em concentrações muito reduzidas, como $\mu \mathrm{g} \cdot \mathrm{L}^{-1}$ ou ng. $\mathrm{L}^{-1}$.

Uma dessas substâncias é o tributilestanho (TBT), um agente biocida presente em tintas anti-inscrustantes de embarcações responsável pelo desenvolvimento de características masculinas, como desenvolvimento de pênis e canal deferente (imposex), em fêmeas de gastrópodes. Em algumas espécies os efeitos foram tão severos que houve redução na população ou até mesmo extinção da espécie. Ensaios laboratoriais demonstraram que concentrações de 5 ng. $\mathrm{L}^{-1}$ já são capazes de induzir o imposex em fêmeas adultas de caracóis 
marinhos, e apenas $1 \mathrm{ng} . \mathrm{L}^{-1}$ causa efeito nas formas juvenis (Gibbs et al., 1991; Goodhead e Tyler, 2009).

No final dos anos 1980 teve início a investigação sobre a feminização de peixes que habitavam os corpos receptores de efluentes no Reino Unido. Nessas espécies, normalmente unissexuais, foram observados caracteres de intersexualidade, como a produção de vitelogenina (VTG), uma proteína produzida pelas fêmeas, e que pode ser utilizada como biomarcador de exposição a agentes estrogênicos. Estudos posteriores mostraram evidências de que a indução à feminização dos peixes machos estava ocorrendo pela presença de estrógenos sintéticos e naturais nos efluentes, e que o fenômeno ocorria mesmo a grandes distâncias do ponto de descarga (Sumpter, 1998; Goodhead e Tyler, 2009).

Apesar de todos os relatos na literatura, o consenso sobre o problema dos disruptores endócrinos sobre a saúde dos animais e dos seres humanos ocorreu apenas em 1991, quando foi realizada a conferência de Wingspread (USA), sob coordenação de Theo Colborn e colaboradores. Neste encontro, que reuniu experientes pesquisadores de áreas distintas, foi sugerido pela primeira vez o termo "disruptores endócrinos". A conferência teve como proposta agrupar os resultados de pesquisas em diferentes áreas sobre a magnitude do problema dos disruptores endócrinos no meio ambiente, identificar as conclusões que podiam ser feitas com base nos estudos realizados até aquele momento, e estabelecer as pesquisas necessárias para esclarecer as incertezas remanescentes. O assunto tornou-se ainda mais público com a publicação da obra "O futuro roubado", de Theo Colborn, Dianne Dumanoski e John P. Myers, em 1996. (Matthiessen, 2003; Colborn et al. 2002).

Desde então, várias ações vêm sendo adotadas por órgãos governamentais e não governamentais, entre eles, a União Européia, a Agência Ambiental Americana (USEPA), o Programa Internacional de Segurança Química (International Programme on Chemical Safety, IPCS), a Organização Mundial da Saúde (OMS) e a Organização para Cooperação e Desenvolvimento Econômico (Organization for Economic Co-operation and Development, OECD) em relação à 
problemática dos disruptores endócrinos (Bila e Dezotti, 2007). Na TAB. 1 podem ser observadas algumas medidas adotadas, como a organização de workshops, formação de comitês e emissão de relatórios por estas agências.

TABELA 1. Ações adotadas por entidades governamentais e não-governamentais sobre os disruptores endócrinos.

\begin{tabular}{|c|c|c|}
\hline ANO & ORGANIZAÇÃo & Proposta \\
\hline 1992 & $\begin{array}{l}\text { WWF - World Wildlife } \\
\text { Fund }\end{array}$ & $\begin{array}{l}\text { Organizou a Conferência de Wingspread, } \\
\text { resultando na Declaração de Wingspread. }\end{array}$ \\
\hline 1994 & $\begin{array}{l}\text { Instituto Nacional de } \\
\text { Ciências Ambientais e da } \\
\text { Saúde (NIEHS/USA) }\end{array}$ & $\begin{array}{l}\text { Revisão sobre a origem, efeitos na biologia } \\
\text { celular e desenvolvimento, e implicações dos } \\
\text { estrógenos ambientais à saúde. }\end{array}$ \\
\hline 1995 & $\begin{array}{l}\text { Agência Ambiental } \\
\text { Federal Alemã }\end{array}$ & $\begin{array}{l}\text { Discussão sobre ocorrência e impacto dos } \\
\text { DEs, e riscos potenciais que podem causar } \\
\text { aos seres humanos e outros animais. }\end{array}$ \\
\hline 1995 & USEPA & $\begin{array}{l}\text { Seminário para avaliar os riscos à saúde e } \\
\text { efeitos ambientais dos DEs. }\end{array}$ \\
\hline 1995 & $\begin{array}{l}\text { Ministério do meio } \\
\text { ambiente e energia da } \\
\text { Dinamarca }\end{array}$ & $\begin{array}{l}\text { Avaliação dos efeitos de substâncias } \\
\text { estrogênicas no desenvolvimento e nas } \\
\text { funções do sistema reprodutivo masculino. }\end{array}$ \\
\hline 1995 & USEPA & $\begin{array}{l}\text { Seminário para avaliar as pesquisas } \\
\text { necessárias para avaliação de risco dos efeitos } \\
\text { dos disruptores endócrinos na saúde e meio } \\
\text { ambiente. }\end{array}$ \\
\hline 1996 & $\begin{array}{l}\text { Comissão da } \\
\text { Comunidade Européia }\end{array}$ & $\begin{array}{l}\text { Seminário europeu sobre os impactos dos DEs } \\
\text { na saúde dos animais e seres humanos. }\end{array}$ \\
\hline 1996 & $\begin{array}{l}\text { SETAC (Sociedade de } \\
\text { Toxicologia Ambiental e } \\
\text { Química) }\end{array}$ & $\begin{array}{l}\text { Seminário para avaliar os efeitos dos } \\
\text { disruptores endócrinos sobre os animais. }\end{array}$ \\
\hline 1996 & USEPA & $\begin{array}{l}\text { Seminário para desenvolvimento de estratégia } \\
\text { para avaliar o risco dos } D E \text { ao meio ambiente. }\end{array}$ \\
\hline 1997 & UNEP; USEPA & $\begin{array}{l}\text { Seminário Internacional sobre disruptores } \\
\text { endócrinos. }\end{array}$ \\
\hline 1997 & $\begin{array}{l}\text { Agência Ambiental } \\
\text { Federal Alemã }\end{array}$ & $\begin{array}{l}\text { Seminário sobre os efeitos dos DEs no } \\
\text { comportamento e desenvolvimento neural. }\end{array}$ \\
\hline 1997 & USEPA & $\begin{array}{l}\text { Relatório especial sobre análise e efeitos dos } \\
\text { DEs no meio ambiente. }\end{array}$ \\
\hline 1997 & OECD & $\begin{array}{l}\text { Crítica avaliação dos métodos existentes para } \\
\text { detecção de hormônios sexuais com potencial } \\
\text { ação disruptora. }\end{array}$ \\
\hline 1997 & $\begin{array}{c}\text { Associação Japonesa } \\
\text { das Indústrias Químicas }\end{array}$ & $\begin{array}{l}\text { Avaliação do estado de arte dos DEs no Japão } \\
\text { e pesquisas necessárias. }\end{array}$ \\
\hline 1998 & $\begin{array}{l}\text { Agência de Proteção } \\
\text { Ambiental Sueca }\end{array}$ & $\begin{array}{l}\text { Avaliação dos efeitos prejudiciais dos DEs } \\
\text { sobre a reprodução e desenvolvimento. }\end{array}$ \\
\hline
\end{tabular}


...continuação TABELA 1.

\begin{tabular}{|c|c|c|}
\hline 1999 & $\begin{array}{l}\text { Comissão da } \\
\text { Comunidade Européia }\end{array}$ & $\begin{array}{l}\text { ldentificação do problema dos DE, suas } \\
\text { causas, conseqüências e definição das } \\
\text { medidas adequadas para dar uma resposta ao } \\
\text { problema. }\end{array}$ \\
\hline 2000 & $\begin{array}{l}\text { Agência Ambiental e de } \\
\text { Saúde Canadense }\end{array}$ & $\begin{array}{l}\text { Seminário sobre substâncias disruptoras no } \\
\text { meio ambiente no Canadá. }\end{array}$ \\
\hline 2001 & $\begin{array}{l}\text { Agência Ambiental } \\
\text { Federal Alemã }\end{array}$ & Segundo seminário sobre o estado dos DEs. \\
\hline 2001 & $\begin{array}{l}\text { Comissão da } \\
\text { Comunidade Européia }\end{array}$ & $\begin{array}{l}\text { Primeiro relatório sobre o progresso dos } \\
\text { trabalhos da comunidade européia sobre os } \\
\text { DEs. }\end{array}$ \\
\hline 2002 & OECD & $\begin{array}{l}\text { Avaliação dos métodos de ensaios para as } \\
\text { substâncias estrogênicas. }\end{array}$ \\
\hline 2002 & OMS & $\begin{array}{l}\text { Avaliação global do estado da arte da ciência } \\
\text { dos DE. }\end{array}$ \\
\hline 2003 & IEH & $\begin{array}{lll}\text { Relatório de avaliação do } & \text { progresso } \\
\text { internacional da pesquisa dos DE. } & \\
\end{array}$ \\
\hline 2004 & $\begin{array}{l}\text { Comissão da } \\
\text { Comunidade Européia }\end{array}$ & $\begin{array}{l}\text { Segundo relatório sobre o progresso dos } \\
\text { trabalhos sobre os DE. }\end{array}$ \\
\hline
\end{tabular}

Fonte: Bila e Dezotti, 2007 e Damstra et al. 2002.

\subsection{SISTEMA ENDÓCRINO E MODOS DE AÇÃO DOS INTERFERENTES HORMONAIS}

Os organismos multicelulares necessitam de um mecanismo que integre e controle a funcionalidade das diferentes células, e este papel é exercido pelos sistemas nervoso e endócrino. Estes sistemas trabalham muitas vezes de forma coordenada, o primeiro recebe um estímulo, que pode ser externo ou interno, enquanto que o segundo formula uma resposta a este estímulo. Dessa forma, o sistema endócrino é responsável por processos vitais ao organismo, como velocidade das reações químicas, permeabilidade das membranas celulares, níveis de composição do sangue e pressão sanguínea, características sexuais primárias e secundárias, manutenção da homeostase, entre outros (Birkett e Lester, 2003; Guyton, 1997; Lintelmann et al., 2003).

O sistema hormonal é formado por um conjunto de glândulas endócrinas localizadas em diferentes partes do organismo e que apresentam como característica a capacidade de produzir ou secretar substâncias químicas 
denominadas de hormônios. As glândulas que compõem o sistema endócrino são: o hipotálamo, a hipófise (ou pituitária), a tireóide, as paratireóides, o timo (durante a infância), o pâncreas, as glândulas suprarrenais (ou adrenais) e as gônadas (testículos e ovários). A adrenalina, a insulina, os estrógenos e a testosterona são exemplos de hormônios produzidos por essas glândulas (Birkett e Lester, 2003).

Os hormônios são transportados pela corrente sanguínea e atuam como mensageiros sobre células específicas ou sobre todas as células. Todavia, apenas tecidos ou órgãos denominados de alvo responderão ao estímulo hormonal, uma vez que estes possuem receptores específicos. Em função da existência de milhares de sítios receptores (2.000 a 100.000 por célula) a resposta celular é ativada mesmo que o hormônio esteja presente em concentrações muito baixas, que normalmente variam de picograma $(\mathrm{pg})$ a micrograma $(\mu \mathrm{g})$ por mililitro de sangue. Dessa forma, este sistema torna-se extremamente sensível e preciso (Lintelmann et al., 2003; Guyton, 1997).

A ligação do hormônio ao seu receptor pode ocorrer de três formas, e varia conforme a composição química dos mesmos. No geral, hormônios peptídeos (proteínas ou derivados) têm seus receptores na membrana celular. Hormônios esteróides (derivados do colesterol) ligam-se a receptores protéicos localizados intracelularmente, no citoplasma, onde são transportados até o núcleo celular e atuam sobre a molécula de DNA. Os receptores para hormônios tireóideos (formados a partir do aminoácido tirosina) são encontrados no núcleo das células. Após ocorrer a ligação entre o hormônio e o receptor, conhecido como princípio de "chave-fechadura", os hormônios ativam os receptores e então uma resposta enzimática em cadeia é produzida (FIG. 1a). Esse processo fisiológico é controlado por complexos mecanismos de retroalimentação, conhecido como feedback, que podem ser negativos ou positivos. Em função destes mecanismos os níveis hormonais no plasma sanguíneo se mantêm adequados e dentro de limites muito precisos, sendo este controle exercido pelo sistema nervoso, especialmente pelo hipotálamo (Guyton, 1997; Lintelmann et al., 2003; Junqueira e Carneiro, 2004). 
Apesar da alta afinidade dos receptores pelos hormônios, as substâncias classificadas como DEs também podem ligar-se aos receptores celulares, e mesmo em baixas concentrações, alterar a resposta natural do corpo e gerar efeitos deletérios (Birkett e Lester, 2003). Segundo Damstra e colaboradores (2002), o fato de seres humanos ou animais serem expostos à compostos químicos disruptores não significa necessariamente que um distúrbio de ordem endocrinológica será desencadeado, uma vez que o nível e o tempo de exposição são fatores importantes. Entretanto, sabe-se que alterações no equilíbrio hormonal durante períodos críticos da vida, como início da fase embrionária, durante a gravidez e lactação podem levar a sérias consequências para o indivíduo ou para gerações futuras (Reis Filho et al., 2006; Kavlock et al., 1996).

Segundo Lintelmann e colaboradores (2003) os principais modos de ação dos DEs são como mimetizador e bloqueador dos hormônios endógenos. No primeiro caso, a substância exógena liga-se ao receptor celular, imitando o hormônio natural e é capaz de produzir uma resposta. A função biológica é afetada por haver uma superprodução na resposta ou por esta resposta ser produzida no momento errado. Neste caso, o efeito é denominado de agonista (FIG 1b). No efeito antagonista, a ligação entre o composto químico e o receptor não resultará em uma resposta diminuída ou em resposta alguma, estando o agente exógeno atuando como um bloqueador, uma vez que o hormônio natural não poderá interagir com o seu receptor (FIG 1c).

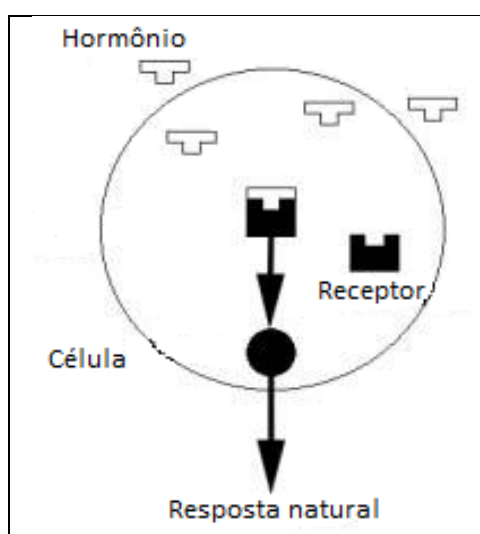

(a)

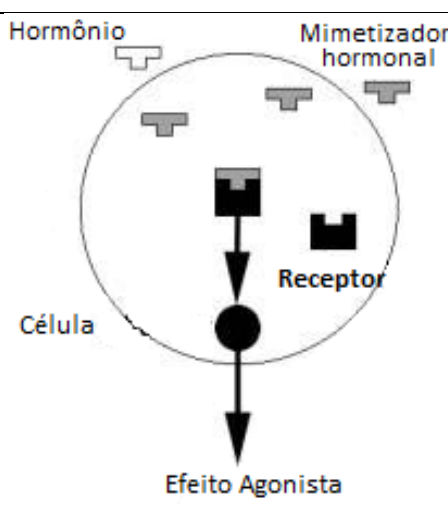

(b)

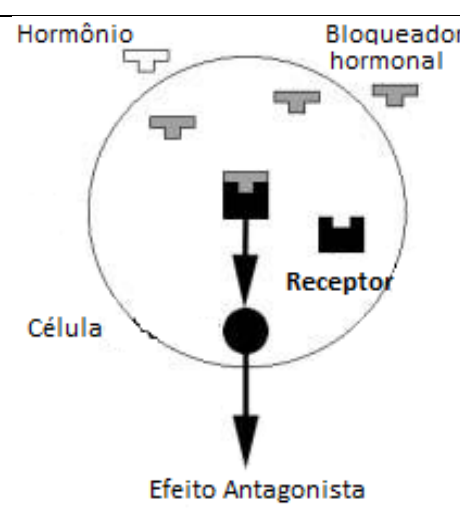

(c)

FIGURA 1. Modos de interferência dos DEs no sistema endócrino. (a) resposta natural, (b) efeito agonista, (c) efeito antagonista (Adaptado de Birkett e Lester, 2003). 
Todavia, mecanismos indiretos de disfunções também podem ser atribuídos aos interferentes hormonais, como alterações na produção, transporte, metabolismo e eliminação dos hormônios ou na ativação dos sítios receptores. É o que ocorre quando há inibição na produção de enzimas que controlam a síntese ou a degradação de hormônios esteróides, ocasionando alterações na concentração hormonal. Ou ainda, quando a quantidade de receptores celulares é afetada, para baixo, pela ligação da substância exógena ao receptor, ou para cima, quando o aumento na resposta leva a formação de mais receptores. Os modos de ação dos DEs são complexos e por isso não estão totalmente esclarecidos (Birkett e Lester, 2003; Goodhead e Tyler, 2009).

\subsection{CaracterizaçÃo dos compostos de interesse}

Muitos compostos com ação comprovada ou suspeita de disfunção endócrina são também classificados como micropoluentes orgânicos, substâncias tóxicas persistentes (STP) ou poluentes orgânicos persistentes (POPs). A relação de compostos hormonalmente ativos abrange um extenso número de substâncias que estão presentes nos bens de consumo da sociedade contemporânea, seja direta ou indiretamente, como, por exemplo, em alimentos, cosméticos, produtos de higiene pessoal, produtos de limpeza e brinquedos infantis (Ghiselli e Jardim, 2007; Birkett e Lester, 2003). Segundo Goodhead e Tyler (2009) o número de agentes DEs tem aumentado consideravelmente desde as primeiras evidências científicas em função da execução de ensaios in vitro e in vivo e de novos métodos de análise.

Agências ambientais de todo o mundo (Comissão da Comunidade Européia, USEPA, UKEA) elaboraram listas de substâncias potencialmente disruptoras endócrinas com base nas informações disponíveis na literatura (Birkett e Lester, 2003; Bila e Dezotti, 2007). Em 1999, a União Européia emitiu um relatório que visou identificar o problema dos disruptores endócrinos, assim como suas causas e conseqüências (CEC, 1999). A partir deste relatório iniciouse um estudo para a elaboração de uma lista de substâncias prioritárias. O estudo foi realizado entre os anos de 2000 e 2006, sendo dividido em três etapas. Ao 
final, um total de 575 substâncias foi investigado. Destas, 320 apresentaram evidências, ou potenciais evidências, para causar efeitos desreguladores. Outros 109 compostos não foram mantidos na lista de substâncias prioritárias, pois apresentaram dados insuficientes de disfunção endócrina ou porque havia poucas evidências científicas. 147 substâncias foram excluídas durante o processo de avaliação, por tratarem-se de misturas, registros duplos ou serem de relevância questionável (CEC, 2007).

De maneira simplificada, os DEs podem ser agrupados em duas classes de substâncias (CEC, 1999; Reys, 2001):

- Naturais: incluem os hormônios naturais femininos - estrógenos e progestógenos; e masculinos - andrógenos; e os hormônios vegetais fitoesteróides.

- Sintéticas: representadas pelos fármacos - hormônios sintéticos utilizados em contraceptivos, tratamentos de reposição hormonal ou drogas com aplicação veterinária; agrotóxicos - inseticidas, herbicidas, fungicidas e moluscicidas; e produtos industriais, como as matériasprimas - plastificantes e alquilfenóis, e subprodutos - dioxinas, bifenilas e hidrocarbonetos policíclicos aromáticos (HPAs).

Como pode ser observado, a maioria dos compostos que causam efeitos adversos no sistema endócrino de animais e de seres humanos são de origem antrópica. Essas substâncias são designadas de xenoestrógenos, substâncias sintetizadas pelo Homem (xenobióticos) que não apresentam estrutura esteróide, mas possuem mecanismo de ação similar aos estrogênios endógenos (Goloubkova e Spritzer, 2000).

Os seis compostos xenoestrógenos abordados por este estudo pertencem a quatro grupos de DEs - compostos orgânicos oxigenados (ftalatos e bisfenol A), alquilfenóis etoxilados (nonilfenol), pesticidas (pentaclorofenol) e hidrocarbonetos policíclicos aromáticos (benzo[a]pireno), estando todas as substâncias presentes nas listas de substâncias prioritárias de agências como a 
USEPA (United States Environmental Protection Agency), UKEA (United Kingdom Environment Agency), OSPAR (Oslo and Paris Commission), JEA (Japan Environment Agency) e WWF (World Wildlife Fund) (Birkett e Lester, 2003).

\subsubsection{Ftalatos}

Ésteres de ácido ftálico, conhecidos genericamente como ftalatos, são substâncias orgânicas derivadas do ácido 1,2-benzeno dicarboxílico utilizadas há mais de 40 anos. A estrutura consiste em um anel benzênico ligado a dois grupos éster. Comercialmente, os ftalatos são produzidos pelo processo de esterificação a partir do anidrido ftálico (obtido por oxidação do naftaleno) e de alcoóis. Dos milhares de ftalatos já sintetizados, menos de $1 \%$ tem aplicação conhecida e fabricação em escala comercial. Estima-se que a produção mundial de ftalatos seja de 4.300 .000 toneladas por ano, a qual vem sendo constante nos últimos 20 anos (Loureiro, 2002; Peijnenburg e Struijs, 2006).

Os ftalatos são substâncias líquidas, incolores e inodoras, utilizadas como aditivos para dar flexibilidade e maior durabilidade aos plásticos, especialmente ao cloreto de polivinila (PVC). Estão presentes em uma grande variedade de produtos e bens de consumo, incluindo cosméticos, produtos de cuidado pessoal, cápsulas para fármacos, material médico-hospitalar, brinquedos infantis, embalagens de alimentos, materiais de limpeza e construção, solventes e óleos lubrificantes (NRC, 2008; Alves et al., 2007).

Os ftalatos de baixo peso molecular compreendem as moléculas que possuem de um a quatro átomos de carbono na cadeia éster, estando incluídos neste grupo o dietilftalato (DEP) e o dibutilftalato (DBP), alvos deste estudo. Os ftalatos que apresentam cinco ou mais átomos de carbono na cadeia são considerados de alto peso molecular (NRC, 2008). Segundo Gómez-Henz e Aguilar-Caballos (2003) o dietilftalato e o dibutilftalato são principalmente utilizados em medicamentos, cosméticos (perfumes e esmaltes) e produtos de cuidado pessoais (xampus e loções). O DEP pode ainda ser utilizado como álcool desnaturante, e o DBP tem aplicação em tintas para impressoras e adesivos. 
Nas FIG. 2 e 3 estão representadas as estruturas químicas dos dois ftalatos de interesse para esta pesquisa, assim como suas propriedades físicoquímicas, que são uma importante ferramenta para o entendimento do comportamento e destino desses compostos no meio ambiente. Como pode ser observado o DEP apresenta maior solubilidade em água quando comparado ao DBP. O coeficiente de partição octanol/água $\left(\log \mathrm{K}_{\text {ow }}\right.$ ) indica a afinidade do composto pela fase orgânica ou aquosa e seu caráter lipofílico. Quanto maior o valor de $\mathrm{K}_{\mathrm{ow}}$ mais hidrofóbico é o composto, no caso dos ftalatos o aumento da cadeia alquil confere maior hidrofobicidade à molécula. Por meio do coeficiente de adsorção $\left(K_{o c}\right)$ pode-se determinar a adsorção da substância ao material em suspensão na água, sendo este valor crescente com o aumento do caráter apolar do composto. Para um melhor entendimento sobre a liberação da substância para a atmosfera, a pressão de vapor deve ser levada em consideração (Staples et al., 1997; Lintelmann et al., 2003).<smiles>CCOC(=O)c1ccccc1C(=O)OCC</smiles>

Dietilftalato (DEP)
Número CAS: 84-66-2

Peso molecular: 222,24 g. mol ${ }^{-1}$

Solubilidade em água $\left(a 25^{\circ} \mathrm{C}\right): 1100 \mathrm{mg} \cdot \mathrm{L}^{-1}$

$\log K_{\text {ow: }}: 2,38$

$K_{o c}: 79.400$ L. $^{-1}$

Pressão de vapor $\left(\right.$ a $\left.25^{\circ} \mathrm{C}\right): 1,33.10^{-4} \mathrm{kPa}$

FIGURA 2. Estrutura química do dietilftalato e propriedades físicoquímicas (Staples et al., 1997).

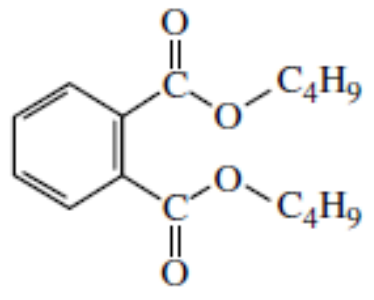

Dibultilftalto (DBP)
Número CAS: 84-74-2

Peso molecular: 278,34 g. $\mathrm{mol}^{-1}$

Solubilidade em água $\left(\right.$ a $\left.25^{\circ} \mathrm{C}\right): 11,2 \mathrm{mg} \cdot \mathrm{L}^{-1}$

$\log K_{\text {ow }}: 4,45$

$K_{o c}: 100.000$ L. $^{-1}$

Pressão de vapor $\left(\right.$ a $\left.25^{\circ} \mathrm{C}\right): 3,60.10^{-6} \mathrm{kPa}$

FIGURA 3. Estrutura química do dibutilftalato e propriedades físicoquímicas (Staples et al., 1997; Oehlmann et al., 2008). 
Por não serem ligados quimicamente à matriz polimérica, os ftalatos podem ser lixiviados ou migrarem para o meio ambiente durante o uso de materiais que os contenham, especialmente quando estes são expostos a altas temperaturas, ou ainda durante o processo de manufatura. Estes compostos são contaminantes ubíquos, sendo encontrados em amostras de água, solo, ar, alimentos e fluidos corporais (urina e líquido amniótico, por exemplo). Os ftalatos não são considerados persistentes, quando no ambiente podem ser degradados por vias abióticas e bióticas, sendo a última o mecanismo predominante. O tempo de biodegradação em estações de tratamento de esgoto (ETEs) está relacionado ao comprimento da cadeia alquil, porém para ftalatos de cadeia curta, como o DEP e o DBP, estima-se que 90\% são removidos em até 7 dias (NRC, 2008; Oehlmann et al., 2008; Gómez-Henz e Aguilar-Caballos, 2003).

As vias de exposição humana ao ftalatos são múltiplas em função do uso difundido desses compostos. A exposição pode ocorrer por ingestão, quando há migração de ftalatos da embalagem plástica para o alimento ou sucção de brinquedos confeccionados com o material; por inalação de partículas de aerossol; por absorção dérmica, resultante da utilização de produtos cosméticos e de higiene pessoal; ou ainda por via parenteral, no caso de procedimentos médicos. A contaminação pode ainda ocorrer pelo leite materno e migração do corpo da mãe para o bebê pela placenta. A meia-vida dos ftalatos no organismo é mensurada em horas, e ao serem metabolizados estes compostos são biotransformados em seus respectivos monoésteres, sendo os metabólitos eliminados principalmente na urina na forma livre ou conjugada como glucuronídeos (Alves et al., 2007; Diamanti-Kandarakis et al., 2009; NRC, 2008).

Efeitos de disfunção endócrina foram observados em ensaios in vivo para o DBP, DEP e outros ácidos ftálicos. Os ftalatos competem com o estrógeno natural 17ß-estradiol, ligando-se aos receptores estrogênicos e induzindo ou atenuando a resposta biológica (van Wezel, 2000; Gómez-Henz e AguilarCaballos, 2003). Segundo Birkett e Lester (2003), alguns ftalatos possuem uma atividade estrogênica de cerca de seis a sete ordens de magnitude menores quando comparado ao 17 $\beta$-estradiol, com o DBP apresentando maior potencial estrogênico do que o DEP. 
Um estudo realizado com mulheres indianas encontrou associação entre endometriose e altos níveis de di-(2-etil-hexil)-ftalato em amostras de plasma. Casos de câncer de mama em mulheres também foram relacionados à exposição de diferentes ftalatos, entre eles DEP e DBP. Efeitos mais severos estão relacionados à atividade antiandrogênica desses compostos. Má formação de tecidos dependentes de andrógenos foi observada em ratos, coelhos e outros mamíferos machos, resultando em órgãos reprodutivos subdesenvolvidos ou ausentes, criptorquidismo ${ }^{1}$, hipospadia ${ }^{2}$, diminuição da distância anogenital, decréscimo na produção de esperma e alterações na função das células de Leydig (células testiculares responsáveis pela produção do hormônio testosterona). Todos esses efeitos são característicos da síndrome dos ftalatos, e podem ser expressos em homens, sendo a hispospadia ${ }^{2}$ e o criptorquidismo ${ }^{1}$ os eventos mais comuns (Diamanti-Kandarakis et al.; 2009; Damstra et al., 2002; NRC, 2008).

\subsubsection{Alquilfenóis etoxilados: nonilfenol}

Os alquilfenóis etoxilados (APEs) pertencem à classe dos surfactantes não iônicos, sendo empregados em resinas fenólicas, aditivos plásticos, detergentes, emulsificantes, dispersantes, agentes solubilizadores, formulações de pesticidas, óleos lubrificantes, e até mesmo como espermicida em produtos contraceptivos, dentre outras aplicações industriais (85\%) e domésticas (15\%). Dados divergentes são encontrados na literatura quanto ao volume mundial produzido desses compostos, variando de 390 mil a 650 mil toneladas por ano. Deste montante, calcula-se que 80 a $90 \%$ sejam de nonilfenóis etoxilados (NPEs). (Lintelmann et al., 2003; Oliveira et al., 2007; Ying et al., 2002)

O nonilfenol (NP) é o APEs mais comum. Sua estrutura é constituída por um anel fenólico e uma cadeia de nove carbonos (FIG. 4). Este xenobiótico, cuja síntese ocorreu em 1940, é produzido pela alquilação de fenóis com uma mistura de isômeros do nonano, em presença de um catalisador ácido. O produto

\footnotetext{
${ }^{1}$ Durante a gestação não ocorre a descida dos testículos para a bolsa escrotal.

2 Malformação congênita, na qual a abertura do orifício uretral é formada em diferentes localidades da parte de baixo do pênis.
} 
final é uma mistura técnica de mais de 22 isômeros, substituídos predominantemente na posição para, como o 4-nonilfenol, e outros na posição orto, como o 2-nonilfenol. Em condições ambientais, trata-se de um líquido viscoso de cor clara, e imiscível em água. Há poucos usos do NP diretamente, exceto quando presente em uma mistura com diisobutilftalato na constituição de óleos lubrificantes. A maior parte (65\%) do NP sintetizado é utilizada na produção de NPEs, os quais tiveram sua aplicação referida anteriormente (USEPA, 2005; Oliveira et al., 2007; Soares et al., 2008).

Em 1993, Ahel e Giger publicaram dois estudos onde determinaram a solubilidade do NP e de outros alquilfenóis etoxilados em água (Ahel e Giger, 1993a) e o coeficiente de partição dessas substâncias entre a água e solventes orgânicos (Ahel e Giger, 1993b). Os resultados obtidos para o NP são apresentados na FIG. 4, juntamente com outros parâmetros físicos e químicos. A solubilidade em água aumenta em temperaturas mais elevadas e, a $25^{\circ} \mathrm{C}$, foi estimada em $6,35 \mathrm{mg} \cdot \mathrm{L}^{-1}$. O caráter hidrofóbico do NP é confirmado pelo valor de partição octanol/água ( $\log \mathrm{K}_{\mathrm{ow}}=4,48$ ), sendo a partição favorável ao material orgânico. A pressão de vapor indica que trata-se de um composto orgânico semivolátil (Soares et al., 2008).

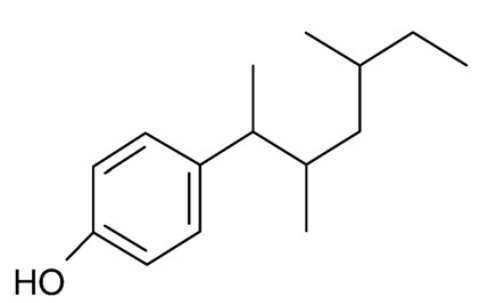

Nonilfenol (NP)

Número CAS: 84852-15-3

Peso molecular: 220,34 g.mol ${ }^{-1}$

Solubilidade em água $\left(\right.$ a $\left.25^{\circ} \mathrm{C}\right): 6,35 \mathrm{mg} \cdot \mathrm{L}^{-1}$

$\log K_{\text {ow: }}: 4,48$

$K_{o c}: 245.470$ L. $^{-1}$

Pressão de vapor $\left(a^{\circ} \mathrm{C}\right): 2,07 \times 10^{-5} \mathrm{kPa}$

FIGURA 4. Estrutura química do nonilfenol e propriedades físico-químicas (Ahel e Giger, 1993a; Ahel e Giger, 1993b; Soares et al., 2008; Ying et al, 2002).

Segundo Ying e colaboradores (2002) as vias de entrada dos alquilfenóis etoxilados no meio ambiente são principalmente a industrial, durante a manufatura, e a decorrente de esgotos não tratados ou efluentes de estações de tratamento de esgoto (ETEs), podendo ainda ser proveniente diretamente de aplicação de pesticidas. Todavia, a principal origem do NP no ambiente está 
relacionada à degradação de NPEs em ETEs que utilizam o tratamento biológico convencional. Estima-se que entre 30 e $35 \%$ dos NPEs são convertidos em NP e NPEs de cadeia curta, sendo estes compostos mais recalcitrantes e mais tóxicos em função da diminuição da cadeia etoxilada e aumento da lipofilicidade (Soares et al., 2008; Ahel et al., 1994a; Ahel et al., 1994b).

Por serem mais persistentes, quantidades consideráveis dessas substâncias podem ser encontradas em águas superficiais que recebem descarga de efluentes, mesmo após o tratamento. Em águas naturais, o comportamento do NP é afetado por processos físico-químicos (temperatura, $\mathrm{pH}$, luminosidade, matéria orgânica) e biológicos (Ahel et al., 1994b). Ahel e coautores (1994a) demonstraram que as concentrações de NP e NPEs em águas superficiais da Suíça sofrem variação nictemeral e sazonal, por influência da temperatura, fotodegradação e atividade biológica. De acordo com Soares e colaboradores (2008) as maiores concentrações do NP podem ser encontradas no verão onde as altas temperaturas e a maior atividade dos microrganismos favorecem a degradação de nonilfenóis etoxilados em nonilfenol.

A capacidade de compostos alquilfenóis etoxilados exibirem atividade estrogênica está vinculada ao posicionamento para do grupo fenólico $\mathrm{OH}$ e da cadeia alquil, significando que nem todos os isômeros de NP são disruptores endócrinos (Lintelmann et al., 2003; Soares et al., 2008). Como mencionado anteriormente, as primeiras evidências que alquilfenóis podiam mimetizar estrógenos ocorreram em 1938 (Dodds and Lawson, 1938), mas foi apenas em 1991 que Soto e outros pesquisadores (1991) descobriram acidentalmente que o nonilfenol, constituinte dos tubos de centrífuga utilizados nos experimentos, era capaz de induzir a proliferação de células de tumores de mama (MCF-7) e de aumentar o número de receptores para progesterona em células humanas sensíveis a estrógenos. Neste mesmo artigo, os autores descrevem os resultados do ensaio in vivo realizado em ratas adultas que tiveram os ovários removidos, onde doses de 20 e $50 \mathrm{mg}$ de nonilfenol levaram a um aumento significativo da atividade mitótica das células endometriais, comprovando a ação estrogênica deste composto. 
O NP pode exercer sua ação como estrogênico ou antiestrogênico, ou ainda como antiandrogênico, quando a interferência se dá no funcionamento normal dos hormônios masculinos andrógenos. O potencial deste composto em relação ao $17 \beta$-estradiol é variável em função do tipo de ensaio e do organismo teste, com médias de $0,3.10^{-4}$ e $2,3.10^{-3}$ ordens de magnitude menores quando comparado ao hormônio natural em ensaios in vitro e in vivo, respectivamente. Diversos estudos apontam os efeitos do NP em peixes, como a produção da proteína vitelogenina em machos, alterações histológicas nas gônadas e diminuição nos níveis de testosterona e redução da densidade populacional. Em ratos machos e fêmeas foram observadas anomalias no desenvolvimento do sistema reprodutivo tanto na geração exposta a este poluente como na geração seguinte (Soares et al., 2008; Müller et al., 1998a; Han et al., 2004).

Os seres humanos estão expostos ao NP principalmente pela utilização de produtos de limpeza, consumo de alimentos contaminados e ingestão de água (Oliveira et al., 2007; Ying et al., 2002). A farmacocinética deste composto foi estudada por Müller e colaboradores (1998b), e demonstrou que o NP sofre uma rápida distribuição no tecido adiposo após duas horas de administração oral, sendo apenas $11,5 \%$ eliminado na urina e nas fezes em até oito horas, indicando a possível ocorrência de outros metabólitos que não foram detectados pelo método. As pesquisas encontradas na literatura relatam a presença deste contaminante em diversas amostras biológicas (plasma sanguíneo, tecido adiposo, leite materno), sendo a urina a principal matriz utilizada (Mao et al., 2004; Calafat et al., 2005; Lopez-Espinosa et al., 2009).

Como resultado da preocupação do impacto dos NPEs sobre a saúde humana e da sua alta toxicidade aguda e crônica em animais aquáticos, o uso desses compostos em detergentes domésticos e industrial foi proibido em 2000 na União Européia (EC, 2002). E outros países como o Canadá e o Japão, estão substituindo o NP etoxilado por outros surfactantes, especialmente por álcool etoxilado (Soares et al., 2008). A legislação brasileira ainda não apresenta nenhuma restrição quanto ao uso dessas substâncias. 


\subsubsection{Bisfenol A}

Obtido pela combinação de duas moléculas de fenol com uma de acetona em pH ácido e altas temperaturas, o bisfenol A (BPA), cuja estrutura química pode ser vista na FIG. 5, foi sintetizado pela primeira vez em 1891. Entretanto, sua comercialização industrial ocorreu apenas em meados de 1950 quando E.C. Dodds anunciou a produção de resinas epóxi contendo BPA. Em 1957 a Bayer e a General Eletric descobriram outro uso para esta substância quando polimerizado o BPA dá origem a um plástico rígido, denominado policarbonato. Atualmente essas são as duas principais aplicações para o bisfenol $A$, e que fazem deste um dos compostos químicos de maior produção mundial, tendo sido prevista a produção de 5 milhões de toneladas para o ano de 2010 (Staples et al., 1998; Vogel, 2009; Ballesteros-Gómez et al., 2009).

Dentre os usos das resinas epóxi pode-se citar: revestimento de latas de alimentos, embalagens para fármaco, adesivos e selantes dentários. Os policarbonatos possuem mercado consumidor mais abrangente, sendo encontrados em produtos eletro-eletrônicos (celulares e peças para computadores), equipamentos automotivos, discos compactos (CDs e DVDs), embalagens para alimentos, como as garrafas plásticas para água, mamadeiras e equipamentos médicos e laboratoriais. As demais aplicações do BPA são principalmente na manufatura de outros tipos de resinas e a produção de cloreto de polivinila (PVC), porém juntos, esses usos não somam 5\% nos Estados Unidos (Goloubkova e Spritzer, 2000; Vogel, 2009; EC, 2003).

Em condições ambientais, o BPA é um sólido branco, comercializado na forma de pó ou cristais. Como pode ser observado na FIG. 5, a solubilidade em água é moderadamente alta. Os valores de partição entre octanol/água $\left(\log \mathrm{K}_{\mathrm{ow}}\right.$ ) e entre sólidos suspensos ( $\log \mathrm{K}_{\mathrm{oc}}$ ) indicam a tendência deste composto em ser adsorvido na matéria orgânica (EC, 2003; Lintelmann et al., 2003). Segundo Staples e coautores (1998) a aplicação de um modelo de distribuição sugere que $48 \%$ do BPA lançado no ambiente tem tendência de ligar-se ao solo e sedimento, enquanto $50 \%$ permaneceria na coluna d'água. Sua pressão de vapor é considerada baixa. 


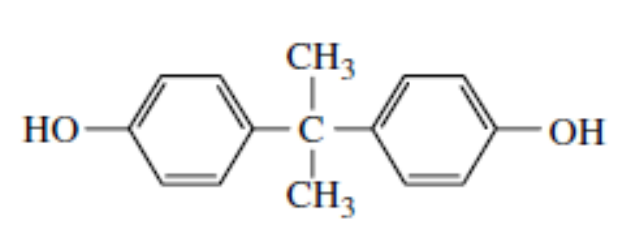

Bisfenol A (BPA)
Número CAS: 80-05-7

Peso molecular. 228,29 g. $\mathrm{mol}^{-1}$

Solubilidade em água $\left(\right.$ a $\left.25^{\circ} \mathrm{C}\right): 120 \mathrm{mg} \cdot \mathrm{L}^{-1}$

$\log K_{\text {ow: }}: 3,4$

$\log K_{o c}: 2,5-3,2$

Pressão de vapor $\left(\right.$ a $\left.25^{\circ} \mathrm{C}\right): 5,3 \times 10^{-9} \mathrm{kPa}$

FIGURA 5. Estrutura química do bisfenol $A$ e propriedades físico-químicas (EC, 2003; Staples et al., 1998).

Pelo grande volume produzido e pelo seu uso difundido em diversos produtos, a quantidade de BPA lançado no meio ambiente é considerável. As rotas de entrada fazem com que este composto seja encontrado no ar, água, sedimento e solo. As vias de contaminação podem ser pontuais (diretas), como em acidentes com derramamento da substância ou em descarga de efluentes de indústrias fabricantes, ou difusas (indiretas), pela lixiviação de produtos finais que o contenham (Lintelmann et al., 2003; Staples et al., 1998). Na revisão de Staples e colaboradores (1998), assim como no relatório da Comunidade Européia (2003) são descritos diversos ensaios de biodegradação que demonstraram que o BPA é biodegradável em grande parte dos testes laboratoriais, e que este composto é degradado em ETEs, com remoção superior a 90\% sob condições aeróbias, e em águas naturais com perda superior a $96 \%$ no período de 3 a 5 dias. 0 tempo de meia-vida no BPA é estimado em 4 dias.

Além dos compartimentos ambientais, o BPA pode ainda ser detectado na saliva, por escapar das resinas utilizadas em tratamentos dentários, ou em alimentos, pela migração de embalagens plásticas, em concentrações de até 139 $\mu \mathrm{g} \cdot \mathrm{g}^{-1}$ de alimento, ou liberação de revestimento de latas, onde as concentrações detectadas variaram de 0,004 a $0,023 \mu \mathrm{g} \cdot \mathrm{g}^{-1}$ de alimento. A USEPA estabeleceu em $50 \mu \mathrm{g} / \mathrm{kg}$ de peso corporal/dia como a dose de referência para exposição oral crônica de BPA. O Brasil, assim como todo Mercosul, fixou o limite de migração específico (LME) em $3 \mathrm{mg}$ de BPA por kilo de alimento, já a União Européia adotou o LME de 600 ng.g ${ }^{-1}$ (0,6 mg. $\mathrm{kg}^{-1}$ ) (Goloubkova e Spritzer, 2000; Brasil, 2003; Ballesteros-Gómez et al., 2009). 
Assim como no caso do nonilfenol, a capacidade do BPA em mimetizar o estradiol já era conhecida desde a década de 1930 (Dodds e Lawson, 1938), e foi "redescoberta" ocasionalmente por pesquisadores da Universidade de Stanford, que perceberam que a atividade estrogênica, inicialmente atribuída a uma levedura, era proveniente da água do meio de cultura autoclavada em frascos de policarbonato. Após isolarem e identificarem a substância se depararam com o bisfenol A (Krishnan et al., 1993). Em ensaios in vitro posteriores foi possível estabelecer que o BPA possui potencial estrogênico de $10^{-3}$ e $10^{-4}$ ordens de magnitude menores em relação ao estradiol. Este xenoestrógeno pode ligar-se aos receptores de estrógenos a ou $\beta$ e induzir uma resposta agonista (Lintelmann et al., 2003; Diamanti-Kandarakis et al.; 2009).

Em seu relatório publicado em 2003, a União Européia (EC, 2003) concluiu, com base em dois estudos in vivo com cobaias, que o BPA não é carcinogênico. Entretanto, no estudo conduzido em conjunto pela USEPA e pelo Instituto Nacional de Ciências Ambientais e da Saúde (NIEHS) é evidenciado que - BPA pode aumentar a susceptibilidade de carcinogênese em células da próstata. Outras desordens causadas por esta substância foram observadas em animais machos, e inclui aumento e desenvolvimento anormal da próstata e do canal uretral, diminuição na produção de esperma e nos níveis de testosterona (Diamanti-Kandarakis et al.; 2009; Mendiola et al., 2010). Em cobaias fêmeas há relatos de puberdade prematura avaliada por meio da abertura vaginal, inibição do desenvolvimento das glândulas mamárias, estimulação do tecido endometrial e aumento da susceptibilidade ao câncer de mama (Goloubkova e Spritzer, 2000; Diamanti-Kandarakis et al.; 2009).

A inalação e a absorção dérmica não contribuem de forma significativa para a exposição dos seres humanos ao BPA, sendo a ingestão de alimentos a principal rota de contaminação. Assim como os demais xenoestrógenos, o BPA é rapidamente absorvido pelo trato gastrointestinal (>95\%). A maior rota do bisfenol A é a biotransformação em bisfenol A-glucuronídeo, seguida da forma conjugada com sulfatos. Vários estudos relatam a presença de metabólitos de BPA em amostras de soro, plasma, sendo a urina a matriz mais indicada (Dekant e Völkel, 2008). Mendiola e coautores (2010) sugerem em sua pesquisa que a exposição 
aos níveis ambientais do BPA pode ser associada à diminuição nos níveis de testosterona livre em homens, mas os efeitos sobre as funções reprodutivas foram muito baixos. Correlação positiva entre o aumento na incidência de doenças cardiovasculares, anormalidades em enzimas hepáticas e diabetes, e altos níveis de BPA foi encontrada no estudo conduzido por Lang e colaboradores. A pesquisa foi realizada nos Estados Unidos e avaliou uma população de 1455 indivíduos com idades entre 18 e 74 anos (Lang et al., 2008).

\subsubsection{Pentaclorofenol}

Considerada uma substância tóxica persistente, o organoclorado pentaclorofenol (PCP) foi amplamente utilizado como preservante de madeira e biocida desde o início de sua produção comercial em 1936, sendo estimada em 50 mil toneladas a produção anual global. Todavia, em função de sua elevada toxicidade, a maioria de seus usos atualmente está proibida e obsoleta (Eisler, 2000; Seiler, 1991). O PCP é produzido pela cloração de fenóis em presença de catalisadores ou por hidrólise alcalina a partir do hexaclorobenzeno. Frequentemente, sua formulação é acompanhada de impurezas, que incluem outros clorofenóis, dioxinas e dibenzofuranos, e que podem apresentar toxicidade mais elevada do que a própria substância (IARC, 1991; IPCS, 1987).

Como mencionado anteriormente, sua principal aplicação comercial é no tratamento de madeiras com a finalidade de evitar a deterioração do tecido vegetal por fungos. Também pode ser utilizado como moluscicida, no combate aos vetores da esquistossomose; inseticida, no controle dos transmissores da elefantíase e cupins; herbicida, como desfolhante na pré-colheita ou dessecação do algodão; e bactericida devido sua forte atividade citotóxica, ainda há relatos de seu uso em sabonetes bactericidas, produtos de cuidados dentários, e como desinfetante doméstico e hospitalar. Em função de sua alta toxicidade, sua manufatura e utilização entraram em declínio em países desenvolvidos na década de 1980, contudo, pelo baixo custo e larga ação, muitos países não baniram ou restringiram esta substância (IARC, 1991; Seiler, 1991). 
Nos Estados Unidos, há um rigoroso controle quanto a seu uso, porém este ainda é permitido exclusivamente como preservante de madeira (USEPA, 2008). No Brasil, o uso agrícola, como pesticida, foi banido em 1985 pela Portaria n 329 do Ministério da Agricultura. Na década seguinte, em 1998, através de Portaria $n^{\circ} 11$ do Ministério da Saúde, a aplicação domissanitário e em campanhas de saúde pública também foi proibida. A última ação adotada em relação ao pentaclorofenol foi a proibição do uso de seus sais (pentaclorofenato de sódio) no tratamento de madeiras, o que ocorreu por meio da Resolução $n^{\circ}$ 164, de 2006, da Agência Nacional de Vigilância Sanitária - ANVISA (Brasil, 2006a; Brasil, 2006b).

Na FIG. 6 é apresentada a estrutura molecular do PCP, assim como suas propriedades físicas e químicas. Se livre de impurezas, trata-se de um sólido de cor branca, mas pode variar à coloração marrom se não estiver puro. É solúvel em solventes orgânicos polares, como etanol e acetona, mas praticamente insolúvel em água, o que pode ser comprovado pelo dado da FIG. 6. Entretanto, na forma de sal, o pentaclorofenato de sódio é solúvel em água. Diferentes valores de partição octanol/água ( $\log \mathrm{K}_{\text {ow }}$ ) são relatados em literatura, variando de 3,32 a 5,12. O coeficiente de adsorção de 3420 é mensurado em solo argiloso, e sua volatilidade é considerada moderada (Seiler, 1991; EPA, 2008).

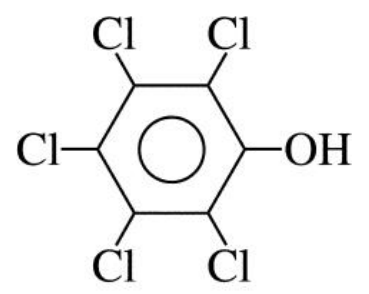

Pentaclorofenol (PCP)
Número CAS: 87-86-5

Peso molecular. 266,34 g.mol ${ }^{-1}$

Solubilidade em água $\left(\right.$ a $\left.20^{\circ} \mathrm{C}\right): 14 \mathrm{mg} \cdot \mathrm{L}^{-1}$

$\log K_{\text {ow }}: 3,32-5,12$

$\log K_{o c}: 3420$

Pressão de vapor $\left(\right.$ a $\left.25^{\circ} \mathrm{C}\right): 0,2 \times 10^{-5} \mathrm{kPa}$

FIGURA 6. Estrutura química do pentaclorofenol e propriedades físicoquímicas (IARC, 1991; Eisler, 2000; EPA, 2008).

O comportamento deste organoclorado no ambiente é fortemente dependente do $\mathrm{pH}$ do meio, sendo a volatilização e a adsorção os principais mecanismos de transporte e distribuição deste contaminante. Em determinados valores de $\mathrm{pH}$ e temperatura, tipos de solventes e madeira, $80 \%$ do 
pentaclorofenol pode ser evaporado de madeiras tratadas dentro do período de 12 meses, levando à contaminação de águas e solos. No ambiente aquático, elevadas concentrações de oxigênio dissolvido, maior incidência solar e pH mais altos favorecem a degradação do PCP, com tempos de meia vida variando de algumas horas a meses, variação esta que pode ser atribuída à aclimatação dos microrganismos e condições de aerobiose (USEPA, 2008; IPCS, 1987).

O pentaclorofenol é tóxico para mamíferos e aves, e sua toxicidade é estendida a organismos não-alvo, presentes no solo e na água. O PCP atua na dissociação da fosforilação oxidativa no interior celular, aumentando o metabolismo corporal. Em seu relatório, o IPCS (1987) relata a ação neuro, imuno e fetotóxica deste poluente, além de sua ação teratogênica. A OMS classifica este organoclorado na classe IB - altamente perigoso, e a União Européia na categoria 3 - altamente tóxico e irritante. Em relação à sua carcinogenicidade, recebe classificação 2B - possível carcinogênico para humanos pela IARC, e B2 provável carcinógeno humano pela USEPA (Brasil, 2006a; IARC, 1991).

Os seres humanos são expostos ao pentaclorofenol por atividades ocupacionais e ingestão de alimentos contaminados. A absorção pelas vias aéreas e consumo de água representam uma pequena parcela de contaminação por este poluente (Eisler, 2000). O PCP é rapidamente absorvido pelo organismo, acumulando-se principalmente nos rins e no fígado. Em estudos com animais, a substância mostrou baixo potencial de bioacumulação, sendo excretada na forma livre ou conjugada com ácidos glicurônicos, principalmente na urina (IPCS, 1987). Embora seu uso esteja restrito ou proibido em diversos países, este organoclorado pode ser detectado em amostras biológicas e ambientais em vários estudos (Gerhard et al., 1999; Zhou et al., 2007; Wilson et al., 2007).

Assim como outros pesticidas, o pentaclorofenol tem apresentado efeitos adversos sobre o sistema endócrino. As principais anomalias relatadas em literatura causadas pela exposição ao PCP referem-se a alterações nos hormônios tireoidianos. Ishihara e coautores (2003) demonstraram que vários compostos químicos sintéticos, entre eles o PCP, são capazes de alterar os níveis dos hormônios T3 e T4 no plasma sanguíneo e interferir na ligação entre os 
hormônios e seus receptores em humanos, aves, peixes e anfíbios. O aumento na infertilidade de mulheres expostas ao PCP foi relatado por Gerhard et al. (1999). Os autores encontraram relação positiva entre a concentração do pesticida em amostras de sangue de mulheres e a diminuição nos níveis dos hormônios progesterona e estradiol, e disfunções tireoidianas, concluindo que a exposição crônica ao PCP afeta o sistema endócrino em algum nível.

\subsubsection{Hidrocarbonetos policíclicos aromáticos: benzo[a]pireno}

Diferentemente dos demais xenoestrógenos abordados neste estudo, os hidrocarbonetos policíclicos aromáticos (HPAs) não são formados intencionalmente pelo homem e podem ter origem natural, embora em proporções míninas se comparada à origem antrópica. Considerados poluentes orgânicos persistentes (POPs), consistem em um amplo número de compostos formados por dois ou mais anéis aromáticos condensados. Por apresentarem importância ambiental e toxicológica, estão presentes em listas de poluentes prioritários de agências ambientais internacionais, como a dos EUA (USEPA), que listou 16 HPAs considerados alvo, e da União Européia, que inclui como prioritários seis hidrocarbonetos poliaromáticos (Birkett e Lester, 2003; Manoli e Samara,1999).

Como fontes naturais de HPAs podem-se citar os processos petrogênicos - incêndios florestais naturais, emissões vulcânicas e afloramentos de petróleo, e os biogênicos - quando há produção destes compostos por bactérias, algas e fungos. A origem antropogênica é significativamente mais relevante e ocorre por combustão incompleta de matéria orgânica. Processos industriais, como produção de alumínio e manufatura de coque, e aquecimento residenciais e industriais, especialmente a partir da queima do carvão, são classificados como fonte estacionária. Enquanto que emissões veiculares são consideradas como fontes móveis (Cavalcante et al., 2007; Birkett e Lester, 2003).

O benzo[a]pireno $(\mathrm{B}[\mathrm{a}] \mathrm{P})$ é um sólido cristalino que possui cinco anéis de benzeno fundidos (FIG. 7), sendo um dos HPAs dos mais estudados. Está presente em ambas as listas de hidrocarbonetos aromáticos prioritários, 
apresenta efeitos embriotóxicos e teratogênicos, além de ser cancerígeno (Froehner e Martins, 2008). Recebe classificação 2A - provável carcinogênico para humanos pela IARC, e B2 - provável carcinógeno humano pela USEPA (IARC, 2008; USEPA, 1995). A estrutura molecular deste contaminante e as características físico-químicas são apresentadas na FIG. 7.<smiles>c1ccc2c(c1)cc1ccc3cccc4ccc2c1c34</smiles>

Benzo[a]pireno $(B[a] P)$
Número CAS: 50-32-8

Peso molecular: 252,32 g.mol ${ }^{-1}$

Solubilidade em água (a $\left.20^{\circ} \mathrm{C}\right): 0,00162 \mathrm{mg} \cdot \mathrm{L}^{-1}$ $\log K_{\text {ow }}: 6,11$ $\log K_{o c}: 1.167$ Pressão de vapor $\left(a 5^{\circ} \mathrm{C}\right): 7,32 \times 10^{-10} \mathrm{kPa}$

FIGURA 7. Estrutura química do benzo[a]pireno e propriedades físicoquímicas (USEPA, 1996; Froehner e Martins, 2008).

O comportamento dos HPAs no meio ambiente está intrinsecamente relacionado ao número de anéis aromáticos. A solubilidade em água diminui com o aumento do número de anéis benzênicos, enquanto que, com a constante de partição octanol-água ocorre relação inversa. Dessa forma, o B[a]P apresenta menor solubilidade em água e maior hidrofobicidade em comparação a compostos com dois ou três anéis (naftaleno e acenaftileno, por exemplo). O valor de log $\mathrm{K}_{\mathrm{oc}}$ apresentado é a média mensurada pela USEPA (1996) e mostra pouca mobilidade dessa substância na fração orgânica do solo. A volatilidade dos HPAs é maior quanto menor o número de anéis, portanto, o $\mathrm{B}[\mathrm{a}] \mathrm{P}$ é pouco volátil (Pereira Neto et al., 2000; Froehner e Martins, 2008).

Por serem formados em processos de combustão e lançados para o ar, a atmosfera é a principal rota de entrada dos HPAs nos sistemas aquáticos e terrestres. A precipitação atmosférica pode ser subdividida em deposição seca e úmida de partículas e vapores. A contaminação dos corpos hídricos pode ainda ocorrer por runoff urbano e descarga de efluentes domésticos e industriais, especialmente os que não recebem tratamento. Pelos baixos valores de solubilidade em água e alta lipofilicidade, os HPAs têm tendência de se acumularem no solo ou no sedimento (Manoli e Samara, 1999). No estudo 
conduzido por Froehner e Martins (2008) foi investigada a distribuição do B[a]P nos compartimentos ambientais, utilizando um modelo matemático em três níveis de complexidade. Resumidamente, os resultados apontaram que quando lançado na atmosfera este HPA tem como principal destino o solo (acima de 90\%) e os sedimentos (variando entre 2 e $8 \%$ ), o meio aquoso e o ar retêm menos de $1 \%$. Porém, por poder ser bioacumulado nos organismos, a contaminação do ambiente aquático por HPAs não deve ser desprezada.

Pela ampla distribuição ambiental, os seres humanos são susceptíveis a contaminação por HPAs em áreas urbanas e rurais. As fontes de exposição incluem o ar contaminado, em regiões industrializadas ou com elevado tráfego de veículos, ou ambientes fechados onde há aquecimento ou fumaça de cigarros; ingestão de HPAs pela sua formação durante o preparo de alimentos; consumo de águas poluídas ou contato com o solo. Quando absorvidos diretamente da fase gasosa, são rapidamente metabolizados e excretados na urina e nas fezes (o $\mathrm{B}[\mathrm{a}] \mathrm{P}$, por exemplo, é eliminado em aproximadamente 1 hora), não sendo observada bioacumulação nos tecidos adiposos (Pereira Neto et al., 2000).

No início da década de 1930 já se sabia que alguns derivados de HPAs podiam atuar como hormônios em fêmeas que tiveram os ovários removidos (Cook et al., 1933). A hipótese de que a atividade carcinogênica de alguns hidrocarbonetos poliaromáticos poderia estar relacionada com a interferência no funcionamento normal do sistema endócrino foi levantada na década de 1960 por Yang et al. (1961). Alguns HPAs possuem estrutura similar aos estrógenos e apresentam atividade estrogênica na ordem de magnitude de $1,12.10^{-2}$ em ensaios in vitro, e de $4.10^{-5}$ em ensaios in vivo em relação ao estradiol. Podem exibir tanto respostas estrogênicas como anti-estrogênicas (Lintelmann et al., 2003; Santodonato, 1997). Vinggaard e coautores (2000) investigaram o efeito agonista ou antagonista de HPAs de 3 a 5 anéis aromáticos sobre receptores de andrógenos em um ensaio in vitro, e demonstraram que o $\mathrm{B}[\mathrm{a}] \mathrm{P}$ é o mais potente antiandrogênico dentre os HPAs avaliados. 


\subsection{LEGISLAÇõES NACIONAIS E INTERNACIONAIS SOBRE DES EM ÁGUAS}

A água potável pode ser uma via de entrada dos DEs no organismo humano se estes compostos estiverem presentes na água bruta e não forem removidos completamente durante o processo de tratamento da água ou se forem formados durante a etapa de desinfecção, formando subprodutos clorados e oxigenados, ou ainda pode ocorrer contaminação durante o armazenamento e distribuição da água. As implicações sobre a saúde humana da ingestão de água contendo DEs ainda são incertas, contudo vêm sendo investigadas (Birkett e Lester, 2003).

Nem todas as substâncias classificadas como disruptores endócrinos são contempladas nas regulamentações referentes à temática água, sejam elas nacionais ou internacionais. Muitos dos compostos incluídos nas legislações referentes à qualidade da água são pesticidas, uma vez que muitos são persistentes e ubíquos nesse compartimento do ambiente, porém, para a inclusão dessas substâncias não foi levado em consideração seus efeitos estrogênicos (Birkett e Lester, 2003). Entretanto, esforços vêm sendo realizados com o intuito de garantir a qualidade das águas superficiais e de consumo humano.

A política de qualidade da água para consumo dos EUA é dada pelo Safe Drinking Water Act (Lei da Água Potável Segura), que foi instituída em 1974 e passou por duas alterações em 1986 e 1996. Essa legislação estabelece o nível máximo dos contaminantes ( $\mathrm{MCL}$, maximum contaminant level), que representa a concentração mais alta do poluente que pode ser aceita na água potável, e a meta do nível máximo dos contaminantes (MCLG, maximum contaminant level goal), que embora não tenha força de lei, representa a concentração abaixo da qual não são previstos riscos para a saúde humana. Embora, na emenda de 1996 muitos compostos DEs tenham sido incluídos na lei americana, dos seis compostos abordados por este estudo, apenas o pentaclorofenol e o benzo[a]pireno são mencionados (USEPA, 2011a; USEPA, 2011b).

A União Européia possui inúmeras diretivas sobre qualidade das águas superficiais e de abastecimento. Sua iniciativa mais importante em relação à 
proteção das águas superficiais, subterrâneas, marinhas e de transição foi a publicação da Diretiva Quadro da Água (Water Framework Directive 2000/60/CE) em 2000. Dentre os objetivos dessa legislação está alcançar uma boa qualidade das águas de todos os países membros até 2015 (Duarte, 2008; EC, 2000). A revisão da legislação sobre água potável de 1980 (80/778/EEC) resultou na Diretiva 98/83/EC, publicada em 1998. Essa lei traz as concentrações máximas aceitas para compostos inorgânicos e orgânicos, mas diferentemente da legislação dos EUA é menos específica para alguns compostos, como no caso dos pesticidas, onde a concentração individual máxima admissível para qualquer pesticida é de $0,1 \mu \mathrm{g} \cdot \mathrm{L}^{-1}$, e a concentração da somatória dos agroquímicos não deve ultrapassar $0,5 \mu \mathrm{g} \cdot \mathrm{L}^{-1}$ na água potável (EC, 1998).

Dentre as legislações vigentes, o Canadá possui uma das mais restritivas para águas superficiais. Suas diretrizes para a qualidade da água potável foram publicadas em 1968, e desde estão vem sofrendo frequentes atualizações. Este país também mantém guias para a qualidade ambiental e a proteção da vida aquática, que incluem um extenso número de substâncias naturais e sintéticas (Canada, 1996; CCME, 2011).

No Brasil, as diretrizes ambientais para o enquadramento e classificação dos corpos de águas doces, salobras ou salinas, e os padrões de lançamento de efluentes são regulamentadas pelas Resoluções no 357 e 397, publicadas, respectivamente, em 2005 e 2008 pelo Conselho Nacional do Meio Ambiente CONAMA. Já o controle e vigilância da qualidade da água para abastecimento da população, assim como os padrões de potabilidade, são definidos pela Portaria $n^{\circ}$ 518 do Ministério da Saúde de 2004, uma republicação da Portaria MS 1.469 de 2000, já que poucas alterações foram realizadas (Brasil, 2005a; Brasil, 2008; Brasil, 2005b; Fernandes Neto e Ferreira, 2007).

Na TAB. 2 estão sintetizados os valores máximos permissíveis dos DEs investigados neste estudo e que são mencionados nas legislações em vigor, nacionais ou internacionais, para águas superficiais e de abastecimento público, assim como o valor de orientação fornecido pelo Guia de Qualidade de Água Potável da Organização Mundial da Saúde, publicado em 2008 (WHO, 2008). 
TABELA 2. Concentrações máximas aceitáveis $\left(\mu g \cdot L^{-1}\right)$ em água potável (1) e água superficial (2) das legislações nacionais e internacionais.

\begin{tabular}{|c|c|c|c|c|c|c|c|c|c|}
\hline \multirow[b]{3}{*}{ Composto } & \multicolumn{9}{|c|}{ VALORES MÁXIMOS PERMISSÍVEIS $\left(\mu \mathrm{g} \cdot \mathrm{L}^{-1}\right)$} \\
\hline & \multicolumn{2}{|c|}{ BRASIL } & \multicolumn{2}{|c|}{$\overline{E U A}$} & \multicolumn{2}{|c|}{$\overline{U E}$} & \multicolumn{2}{|c|}{ CANADÁ } & \multirow{2}{*}{$\frac{O M S}{1^{\text {ix }}}$} \\
\hline & $1^{i}$ & $2^{\mathrm{ii}}$ & $1^{\mathrm{iiii}}$ & $2^{\text {iv }}$ & $1^{v}$ & $2^{\mathrm{vi}}$ & $1^{\mathrm{vii}}$ & $2^{\text {viii }}$ & \\
\hline $\mathrm{B}[\mathrm{a}] \mathrm{P}$ & 0,7 & $0,018^{a} / 0,7^{b}$ & 0,2 & n.m. & 0,01 & 0,1 & 0,01 & 0,015 & 0,7 \\
\hline NP & n.m. & n.m. & n.m & $28^{d} / 6,6^{e}$ & n.m. & 2,0 & n.m. & 1,0 & n.m. \\
\hline PCP & 9,0 & $3,0^{\mathrm{a}}$ & 1,0 & $19^{d} / 15^{e}$ & $0,1^{f}$ & 1,0 & 60 & 0,5 & 9,0 \\
\hline Ftalatos & n.m. & n.m. & $6,0^{c}$ & n.m. & n.m. & n.m. & n.m. & $19^{g}$ & $8,0^{c}$ \\
\hline BPA & n.m. & n.m. & n.m. & n.m. & n.m. & n.m. & n.m. & n.m. & n.m. \\
\hline
\end{tabular}

Fontes:

$i=$ Portaria MS 518/2004 (Brasil, 2005b);

ii = Resolução CONAMA 357/2005 (Brasil, 2005a);

iii = Lei da Água Potável Segura (SDWA, Safe Drinking Water Act) (USEPA, 2011a);

iv = Recomendação Nacional dos Critérios de Qualidade da Água (USEPA, 2009);

$v=$ Diretiva 98/83/EC (EC, 1998);

$v i=$ Diretiva 2008/105/CE (EC, 2008);

vii = Orientações para Qualidade da Água Potável Canadense (Canada, 1996);

viii = Orientações para Qualidade Ambiental Canadense (CCME, 2011);

ix = Guia para Qualidade da Água Potável (WHO, 2008).

\section{Notas}

n.m. = não mencionado

$a=$ valor mais restritivo, referente à classe tipo 1 - águas destinadas ao abastecimento público após tratamento simplificado e criação de pescado;

$b=$ valor menos restritivo, referente à classe tipo 3 - águas destinadas ao abastecimento público após tratamento convencional ou avançado;

$c=$ referente ao composto di (2-etilhexil)ftalato;

$d$ = critério de concentração máxima (CMC) - concentração mais alta de uma substância à qual uma comunidade aquática pode ser exposta brevemente sem resultar em um efeito adverso (toxicidade aguda);

$e$ = critério de concentração contínua (CCC) - concentração mais alta de uma substância à qual uma comunidade aquática pode ser exposta indefinidamente sem resultar em um efeito adverso (toxicidade crônica);

$f=$ valor paramétrico para a concentração individual do pesticida. $A$ somatória de todos os agrotóxicos não deve ultrapassar $0,5 \mu g \cdot \mathrm{L}^{-1}$;

$g=$ referente ao composto dibutilftalato.

Como pode ser observado, apenas para o bisfenol A não existem, até o momento, valores regulamentados nas legislações selecionadas, tanto para águas superficiais quanto para as destinadas ao abastecimento público. Contudo, as concentrações sem efeito previsível (PNEC, Predicted No Effect Concentrations) para organismos aquáticos adotados, respectivamente, pela União Européia e Canadá para este composto são de $1,5 \mu \mathrm{g} \cdot \mathrm{L}^{-1}$ e $0,175 \mu \mathrm{g} \cdot \mathrm{L}^{-1}$ (USEPA, 2010). 


\subsection{Metodologias empregadas na ANÁlise de DES}

A qualidade de um método analítico está intrinsecamente relacionada à qualidade de suas etapas, nas quais estão inseridas as incertezas experimentais. Essas etapas incluem as técnicas de amostragem e de preparo das amostras, além da análise instrumental (Valente e Augusto, 2000). Normalmente o prétratamento da amostra se faz necessário em função da complexidade das matrizes ambientais e das baixas concentrações dos compostos alvo, além de visar a eliminação de interferentes, alcançar os limites de detecção e quantificação requeridos pela técnica empregada, e em última instância, compatibilizar a amostra bruta com o equipamento analítico (Nollet, 2006).

A coleta de amostras ambientais líquidas para análise de disruptores endócrinos normalmente é realizada em frascos de vidro âmbar, os quais são previamente limpos com água ultrapura e solventes orgânicos, como metanol ou acetona. Após a coleta, as amostras devem ser armazenadas a temperatura de $4^{\circ} \mathrm{C}$, e a extração deve ser realizada em até 48h (Ying, 2007). Todavia, os métodos desenvolvidos pela USEPA para análise de esteróides e hormônios (USEPA, 2007b) e de fármacos e produtos de cuidado pessoal (USEPA, 2007a) recomendam a extração em até 7 dias (preferencialmente dentro de 48h), e a análise dos extratos dentro de 40 dias. Para a preservação das amostras, formaldeído $(1 \%, v / v)$ ou ácido sulfúrico $(\mathrm{pH}<3)$ podem ser empregados (Ying, 2007). A USEPA (2007a, 2007b) recomenda adição de tiossulfato de sódio $\left(\mathrm{Na}_{2} \mathrm{~S}_{2} \mathrm{O}_{3}\right)$ em amostras onde há cloro residual para preservação dos analitos.

As etapas subsequentes à coleta normalmente incluem filtração da amostra através de membranas inertes, usualmente de 0,45 $\mu \mathrm{m}$ de diâmetro do poro, para remoção de sólidos em suspensão que poderiam comprometer a etapa posterior; ajuste do $\mathrm{pH}$ para $<4$, pois para compostos fenólicos, como o nonilfenol e o bisfenol, o pH ácido suprime a dissociação e previne a ionização dos analitos, aumentando a eficiência da extração; e a etapa final de isolamento e concentração dos analitos de interesse (Moreira, 2008; Ying, 2007). 


\subsubsection{Extração dos analitos}

Embora outros métodos venham sendo desenvolvidos nas últimas décadas, dentre as técnicas de extração e concentração de DEs em amostras aquosas, o emprego da extração em fase sólida (SPE) continua sendo a mais utilizada, sendo relatado na literatura o emprego de discos e mais comumente cartuchos (Ying, 2007; Richardson, 2010).

A SPE na forma de colunas empacotadas contendo sílica ligada como material adsorvente foi introduzida em 1977, e consiste em uma técnica de separação líquido-sólido baseada nos mecanismos de separação da cromatografia líquida de baixa pressão, onde se emprega uma coluna aberta, denominada de cartucho de extração, a qual contém a fase sólida, sendo esta correspondente à fase estacionária (Simpson, 2000; Lanças, 2004a).

Os analitos presentes na amostra são aprisionados no material adsorvente, e posteriormente removidos com uma pequena quantidade de solvente orgânico. A amostra pode ser percolada com auxílio de vácuo ou pressionada com uma seringa. Anteriormente à passagem da amostra pelo cartucho, este deve ser condicionado com um solvente apropriado. A etapa de lavagem (clean up) é usualmente requerida, e tem por objetivo eliminar os compostos interferentes presentes na amostra (Nollet, 2006; Lanças, 2004a). $\mathrm{Na}$ FIG. 8 é apresentado um esquema com as principais etapas envolvidas no processo de SPE. 


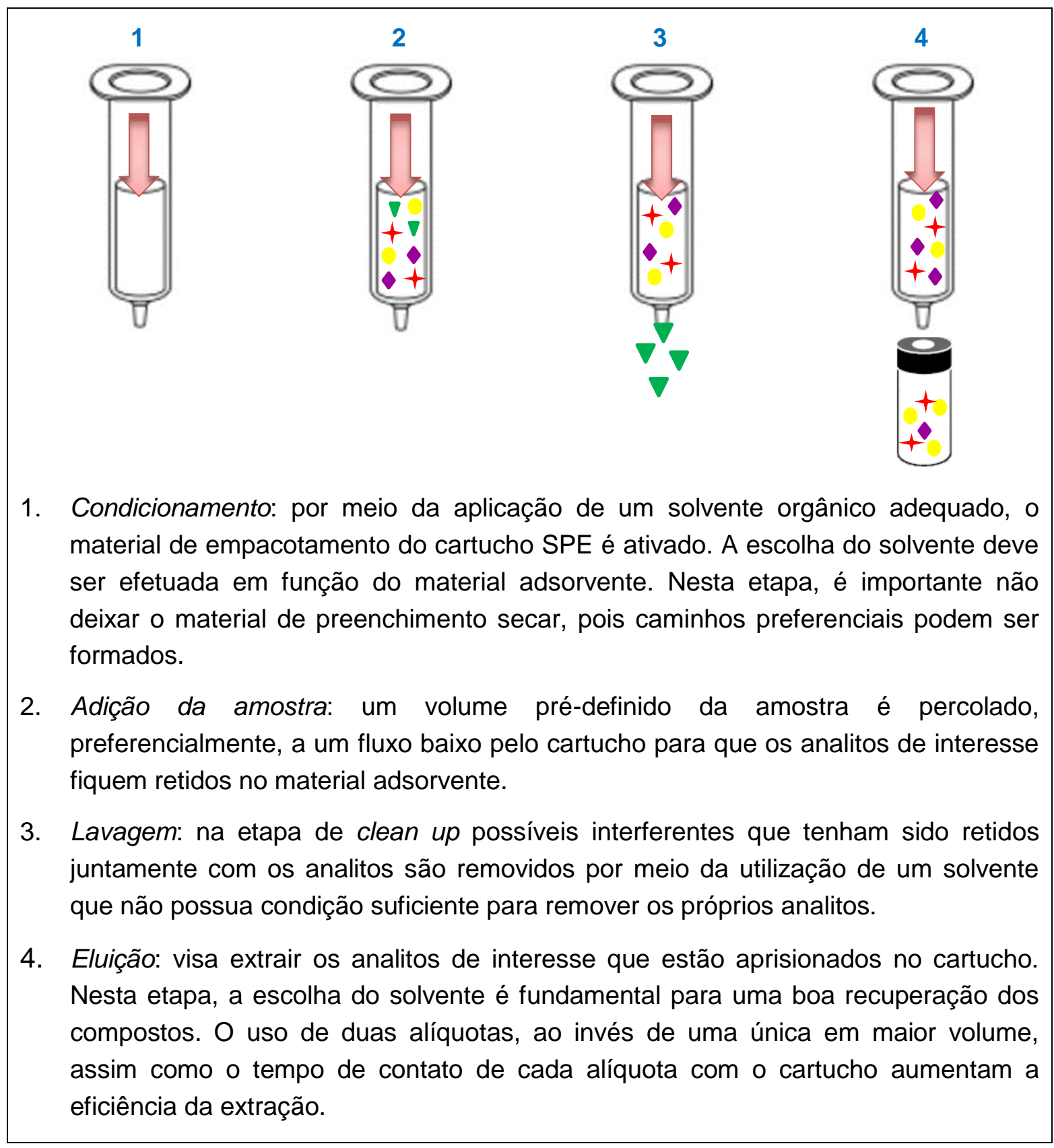

FIGURA 8. Esquema onde são esquematizadas as etapas da extração em fase sólida (SPE).

Diferentes formatos em SPE estão disponíveis no mercado, como cartuchos e discos. O cartucho consiste em um corpo de uma seringa plástica (usualmente de polipropileno), onde o material de empacotamento fica retido entre dois discos de polietileno. A fase estacionária empregada na SPE deve ser escolhida tendo como base as características dos analitos. $O$ grupo octadecilsilano $\left(\mathrm{C}_{18}\right)$ quimicamente ligado à sílica é um dos mais empregados. Possui caráter apolar, sendo denominada, portanto, de fase reversa, onde a fase 
estacionária (material adsorvente) é menos polar que a fase móvel, assim como na cromatografia clássica. Os mecanismos de separação observados na SPE $\mathrm{C}_{18}$ são adsorção e partição (Lanças, 2004a).

Para a análise de interferentes endócrinos a fase mais frequentemente utilizada é a $\mathrm{C}_{18}$, embora cartuchos poliméricos de carbono preto grafitizado e divinilbenzeno ou $\mathrm{N}$-vinilpirrolidona $\left(\mathrm{HBL}^{\mathrm{TM}}\right)$ também sejam relatados na literatura (Lopez de Alda et al., 2003; Ying, 2007). Uma das desvantagens do uso da SPE é a necessidade de grandes volumes de amostra, normalmente 500 ou $1.000 \mathrm{~mL}$, para a concentração.

A mais recente técnica de preparação das amostras consiste no desenvolvimento de adsorventes em duas fases, que possibilita a extração de analitos de diferentes grupos em uma única etapa. Outros métodos que não empregam solventes, como a microextração em fase sólida (SPME, solid-phase microextraction), a microextração com gota única (SDME, single-drop microextraction), extração sortiva em barra de agitação (stir bar sorptive extraction) e a microextração em fase líquida com fibra oca (hollow-fiber membrane microextraction) também são utilizadas, porém menos extensivamente (Lopez de Alda et al., 2003; Richardson, 2010).

\subsubsection{Análise instrumental}

Alguns autores destacam a utilização de técnicas cromatográficas (cromatografia líquida, LC e gasosa, GC) acopladas a sistemas de detecção de alta sensibilidade e especificidade, como a espectrometria de massas (MS ou MS/MS) ou espectrometria de massas de alta resolução (HRMS) como ferramentas analíticas para determinação dos DEs. Embora o uso da cromatografia líquida de alta eficiência, HPCL ou de ultra eficiência, UPLC acoplada ao espectrômetro de massas (LC/MS ou LC/MS/MS) tenha ganhado força nos últimos anos, a técnica de CG/MS tem sido a mais amplamente utilizada nas análises ambientais de DEs (Richardson, 2009; Petrovic et al., 2002). 
Mesmo sendo uma técnica mais antiga e com algumas limitações, muitos laboratórios empregam a cromatografia gasosa em suas análises em parte por causa da alta sensibilidade e vasta aplicabilidade, em parte por conta dos inúmeros métodos já estabelecidos e validados para diferentes compostos e matrizes. Segundo Mansilha et al. (2010) a combinação das técnicas de SPE e GC/MS é tida como uma das mais eficientes para a separação, identificação e quantificação de DEs, mesmo na faixa de nanograma.

\section{Cromatografia gasosa}

A cromatografia a gás é um método de separação no qual os componentes de uma mistura são distribuídos entre duas fases, a fase móvel, caracterizada pelo gás de arraste e a fase estacionária, presente como revestimento interno da coluna cromatográfica. Esta técnica de determinação de substâncias foi inicialmente descrita em 1944, porém, sua aplicação como um método de separação foi relatada apenas em 1952 por James e Martin. O avanço da técnica ocorreu com a adoção de colunas capilares de sílica fundida no final de década de 1970 (Niessen, 2001; Yuwono e Indrayanto, 2004).

Um equipamento de cromatografia gasosa é composto basicamente pelo gás de arraste, controlador da vazão e regulador de pressão, sistema de injeção de amostra, um forno de temperatura programável onde está localizada a coluna cromatográfica, sistema de detecção e um registrador dos dados (Yuwono e Indrayanto, 2004; Collins et al., 2006).

Hélio ou nitrogênio são os gases inertes mais frequentemente utilizados como fase móvel. O gás de arraste deve ser de alta pureza para não interferir na análise, além de não interagir com a fase estacionária e ser compatível com o detector, deve ser levado em consideração ainda sua disponibilidade e custo. A fase móvel na cromatografia gasosa é responsável por carregar a amostra, que foi previamente vaporizada no injetor, pela coluna (fase estacionária). A vaporização das substâncias que constituem a amostra é possível pela aplicação de temperaturas adequadas no injetor (Collins et al., 2006). 
A introdução da amostra no equipamento, usualmente denominada de injeção, é uma etapa crítica da análise. Uma pequena quantidade da amostra deve ser injetada rapidamente no início da coluna cromatográfica. Não deve haver degradação térmica dos analitos ou discriminação dos compostos por diferença de volatilidade. O volume de amostra necessário é variável em função do tipo de coluna (em colunas capilares menores volumes são injetados), das dimensões da coluna e da sensibilidade do detector. Em análises em nível traço, usualmente opta-se pelo modo splitless, onde todo o volume introduzido no equipamento é direcionado à coluna. No modo split, a amostra é dividida em alíquotas (por exemplo, 1:10 ou 1:100), onde apenas uma fração é introduzida na coluna cromatográfica (Niessen, 2001; Yuwono e Indrayanto, 2004).

A coluna cromatográfica, localizada no forno, tem temperatura controlada, e durante a análise pode permanecer constante ou ser aumentada linearmente. Com o acréscimo de temperatura, os componentes da amostra de maior ponto de ebulição ou maior afinidade pela fase estacionária são liberados posteriormente em relação aos demais, e atingem o sistema de detecção em diferentes tempos, dessa forma distintos tempos de retenção são obtidos. O gradiente de temperatura, ou seja, sua programação, é especialmente importante pois possibilita uma melhor separação dos analitos e um menor tempo de análise (Niessen, 2001; Collins et al., 2006).

A fase estacionária na cromatografia gasosa pode ser constituída por um sólido ou líquido, classificando a técnica em cromatografia gás-sólido ou gáslíquido. Na primeira, a fase estacionária é um sólido com grande área superficial, onde se observa a adsorção como mecanismo de separação. A cromatografia gás-sólido tem aplicação na análise de gases e substâncias apolares de baixa massa molar. A cromatografia gás-líquido corresponde a aproximadamente 95\% das aplicações, nesta, a fase estacionária é um líquido pouco volátil que é espalhado ou imobilizado em um suporte sólido inerte (colunas empacotadas) ou serve de revestimento como um fino filme na parede interna de colunas capilares. A separação baseia-se em mecanismos de partição das substâncias entre a fase líquida e a gasosa (Collins et al., 2006; Yuwono e Indrayanto, 2004). 
A coluna cromatográfica é um tubo longo constituído por um material que não deve interagir com a fase estacionária nem com os compostos da amostra, normalmente de vidro, aço inoxidável, alumínio, sílica fundida, entre outros materiais. As colunas podem ser classificadas em empacotadas (recheadas) ou capilares. As primeiras possuem diâmetro interno maior (1 a $4 \mathrm{~mm})$ em relação às capilares $(0,1$ a $0,75 \mathrm{~mm})$. Porém, as capilares ganham em comprimento, podendo chegar a 100 metros, enquanto as empacotadas variam de 2 a 10 metros (Collins et al., 2006; Yuwono e Indrayanto, 2004).

A cromatografia gasosa é uma técnica com alto poder de resolução, capaz de separar dezenas de substâncias em uma mesma análise, e pode alcançar baixos limites de quantificação, o que a torna uma excelente técnica quantitativa. Todavia, uma das desvantagens do uso da cromatografia gasosa é a necessidade da etapa de derivatização para compostos pouco voláteis ou que não são estáveis termicamente, aumentando o custo da análise e o tempo de preparação da amostra, além de poder ocorrer perda do analito pela manipulação adicional (Petrovic et al., 2002; Collins et al., 2006).

A cromatografia a gás não é uma técnica qualitativa eficiente, necessitando de outras técnicas de identificação. Dentre os detectores utilizados em equipamentos de GC pode-se citar os por ionização em chamas (flame ionization detector, FID), por condutividade térmica (thermal conductivity detector, TCD), por capturas de elétrons (electron capture detector, ECD) e o detector por espectrometria de massas (mass spectrometry, MS) (Collins et al., 2006; Johnstone e Herbert, 2002).

\section{Espectrometria de massas}

A espectrometria de massas surgiu no inicio do século XX (1912) quando o pesquisador J.J. Thomson construiu o primeiro espectrômetro de massas, entretanto, esta técnica se modificou rapidamente devido à invenção do analisador quadrupolar em 1953. Atualmente a espectrometria de massas é uma técnica microanalítica de grande importância por ser capaz de fornecer informações qualitativas e quantitativas de misturas orgânicas ou inorgânicas 
complexas, além de ser capaz de elucidar a estrutura dos constituintes de uma amostra (Vega-Bustillos et al., 2001).

O espectrômetro de massas possui três componentes principais: a fonte de íons, o analisador de massas (filtro de massas) e o sistema de aquisição dos dados (detector). O princípio da espectrometria de massas consiste na produção de íons na fase gasosa, que serão posteriormente separados e detectados de acordo com a relação massa-carga $(\mathrm{m} / \mathrm{z})$. Como resultado se obtém um gráfico da abundância relativa dos íons gerados em função da relação $\mathrm{m} / \mathrm{z}$. Com o uso desta técnica, alta seletividade pode ser obtida, o que é de extrema importância em análise quantitativa em níveis traço (Niessen, 2001).

Para que os íons (negativos ou positivos) possam ser gerados, diferentes estratégias de ionização são necessárias em função do tipo de amostra. Como exemplo das fontes de ionização utilizadas na espectrometria de massas, temos a ionização química à pressão atmosférica (atmospheric pressure chemical ionization, APCI), a fotoionização à pressão atmosférica (atmospheric pressure photo ionization, APPI), a ionização por spray aquecido (thermo-spray ionization, TSP); por electrospray (electrospray ionization, ESI), ionização por átomos rápidos (fast atom bombardment, $\mathrm{FAB}$ ), ionização por dessorção a laser assistida pela matriz (matrix-assisted laser dessorption ionization, MALDI), ionização química (chemical ionization, $\mathrm{Cl}$ ) e a ionização por elétrons (electron impact, El) (Moraci, 2008; McCullagh, 2011).

A ionização por elétrons é a mais antiga das técnicas de formação de íons. A amostra na forma gasosa entra na fonte de íons, e é submetida ao bombardeamento por elétrons liberados de um filamento aquecido com energia de colisão de normalmente $70 \mathrm{eV}$. Nesse processo, um elétron é arrancado da molécula gasosa, resultando em um íon com carga positiva. A ionização é realizada em um meio com alto vácuo (com pressão $<10^{-2} \mathrm{~Pa}$ ), evitando colisões intermoleculares. Em função da energia de colisão ser constante, os espectros de massas obtidos são altamente reprodutíveis, desta forma bibliotecas de espectros de massas podem ser utilizadas para auxiliar na identificação de uma substância (Vega-Bustillos et al., 2001; Niessen, 2001). 
Ao serem formados na fonte de ionização os íons são direcionados ao filtro de massas. A análise da relação $\mathrm{m} / \mathrm{z}$ no espectrômetro de massas pode ser realizada de diferentes formas. Podemos citar o analisador por setor magnético, de alta resolução, utilizado em análises isotópicas, e o analisador por tempo de vôo (time of flight, TOF), que também apresenta alta resolução e pode ser utilizado na análise de pequenas a macromoléculas. $O$ analisador quadrupolar é o mais comum, podendo ser do tipo linear (quadrupolo) ou de armadilha de íons (ion trap) (McCullagh, 2011; Niessen, 2001).

O filtro de massa quadrupolo consiste em quatro varetas paralelas, arranjadas em dois pares carregadas eletricamente com cargas opostas. Nestas varetas é aplicada uma voltagem contínua e uma voltagem alternada, sendo estas as responsáveis pela trajetória centralizada dos íons. Variando-se estas voltagens, somente os íons com uma determinada razão massa/carga $(\mathrm{m} / \mathrm{z})$ irão atravessar o filtro quadrupolo numa trajetória helicoidal e atingir o detector, enquanto os demais serão desviados da trajetória central. Os filtros quadrupolo possuem baixa resolução, todavia, podem ser colocados em uma configuração sequencial, denominado de triplo quadrupolo (McCullagh, 2011; Vega-Bustillos et al., 2001).

Dois tipos de detectores são utilizados na espectrometria de massas. $O$ Copo de Faraday (CF) é um sistema mais simples, onde os íons positivos que saem do analisador são chocados contra o corpo metálico do copo e são neutralizados por absorverem um elétron da estrutura metálica. A corrente gerada é detectada por um amperímetro. O detector empregado neste estudo foi o multiplicador de elétrons (ME). A multiplicação ocorre por meio da colisão dos íons positivos com a parede do detector que tem formato de cone. Ao se chocarem, há liberação de elétrons que serão direcionados ao final do cone em função de um gradiente negativo. Nesse processo uma cascata de elétrons é gerada, e a corrente elétrica provocada é proporcional a corrente de íons que entraram no inicio do detector. Os dados gerados serão registrados por um programa computacional resultando no espectro de massas (Vega-Bustillos et al., 2001). 
Os modos de aquisição de dados que podem ser obtidos na espectrometria de massas são por varredura dos íons em uma faixa pré-definida (SCAN) ou por monitoramente seletivo de íons (selective ion monitoring, SIM). No modo SCAN uma série contínua de espectros é adquirida durante a corrida cromatográfica, sendo indicado em análises qualitativas onde as substâncias presentes na amostra são desconhecidas. No modo SIM, apenas alguns íons específicos são detectados durante a análise, o que aumenta a sensibilidade da técnica em até 500 vezes. Desta forma, quando o objetivo é a quantificação, o modo SIM é a melhor alternativa (Niessen, 2001; Yuwono e Indrayanto, 2004).

\subsection{Determinação de XenOestrógenos em amostras aquosas}

Inúmeros são os trabalhos publicados nos últimos anos que investigam a presença de compostos químicos disruptores endócrinos sintéticos em matrizes ambientais, como águas superficiais e potáveis, efluentes brutos e tratados, e em menor quantidade em sedimentos e solos. Porém, é restrito o número de pesquisas onde a avaliação conjunta dos seis interferentes selecionados neste estudo é realizada, normalmente, o que se observa é a separação em grupos específicos dos compostos para a análise.

Em um dos estudos pioneiros para determinação de bisfenol $A$ em amostras de água, Olmo e colaboradores (1997) desenvolveram uma metodologia utilizando extração líquido-líquido e determinação por GC/MS. Os limites de detecção (LD) e quantificação (LQ) do método foram respectivamente mensurados em 0,6 e 2,2 $\mu \mathrm{g} \cdot \mathrm{L}^{-1}$. Talvez em função dos altos limites do método estabelecidos, o BPA ficou abaixo do LD na análise das amostras de água marinha e água subterrânea da Espanha.

A ocorrência de bisfenol $A$ e de isômeros de nonilfenol em águas superficiais de Portugal foram avaliadas por Azevedo et al. (2001). Empregando SPE para concentração de $200 \mathrm{~mL}$ de amostra e determinação por GC/MS, as autoras alcançaram limites de detecção de $0,01 \mu \mathrm{g} \cdot \mathrm{L}^{-1}$ para o NP e de $0,002 \mu \mathrm{g} \cdot \mathrm{L}^{-1}$ para o BPA. Nas 135 amostras analisadas as concentração dos xenoestrógenos 
variaram de $0,2 \mu \mathrm{g} \cdot \mathrm{L}^{-1}$ a $30 \mu \mathrm{g} \cdot \mathrm{L}^{-1}$ e de 0,2 a $4,0 \mu \mathrm{g} \cdot \mathrm{L}^{-1}$ para nonilfenol e bisfenol $\mathrm{A}$, respectivamente.

A pesquisa realizada por Loureiro (2002) visou determinar 16 ácidos ftálicos utilizando SPE $\mathrm{C}_{18}$ e GC/ECD em amostras de água superficial e de sedimento da baía de Guanabara, e de água tratada obtidas diretamente de residências de vários bairros das cidades do Rio de Janeiro e Niterói. Nas amostras de água de torneira, apenas o di(2-etilhexil)ftalato foi encontrado. Nas amostras de água superficial da região costeira, o DEP apresentou concentrações entre $<1 \mathrm{ng} \cdot \mathrm{L}^{-1}$ e $16,8 \mathrm{ng} \cdot \mathrm{L}^{-1}$, as concentrações para o DBP variaram de $1,66 \mathrm{ng} \cdot \mathrm{L}^{-1}$ e 37,9 ng.L'). O DEP não foi detectado nas amostras de sedimento, e as concentrações para o DBP estiveram entre $8,76 \mathrm{ng} \cdot \mathrm{g}^{-1}$ e $59,37 \mathrm{ng} \cdot \mathrm{g}^{-1}$ nos pontos de amostragem de sedimento superficial $(\leq 3 \mathrm{~cm})$.

A presença de ftalatos e bisfenol A e $\mathrm{F}$ foi investigada por Fromme et al. (2002) em amostras ambientais da Alemanha, que incluíram 116 amostras de águas superficiais, 34 amostras de efluente final de ETEs, 31 amostras de lodo das ETEs e 35 amostras de sedimento. As concentrações de BPA encontradas estiveram entre $0,5 \mathrm{ng} \cdot \mathrm{L}^{-1}$ e $410 \mathrm{ng} \cdot \mathrm{L}^{-1}$ nas amostras de água superficial, nos efluentes variaram de $18 \mathrm{ng} \cdot \mathrm{L}^{-1}$ a $702 \mathrm{ng} \cdot \mathrm{L}^{-1}$, e nas amostras de sedimento foram obtidas concentrações entre $0,01 \mathrm{mg} \cdot \mathrm{kg}^{-1}$ e $0,19 \mathrm{mg} \cdot \mathrm{kg}^{-1}$, os valores mais elevados foram detectados nos lodos das estações de tratamento, de $0,004 \mathrm{mg} \cdot \mathrm{kg}^{-1}$ a $1.363 \mathrm{mg} \cdot \mathrm{kg}^{-1}$. As concentrações de bisfenol $\mathrm{F}$ foram bem menores em todos os compartimentos. Dentre os ftalatos, o dibutilftalato foi detectado em todas as amostras, porém em concentrações inferiores ao di(2-etilhexil)ftalato.

Para determinação de dezesseis disruptores endócrinos e pesticidas, entre eles DBP e B[a]P, em amostras aquosas, Brossa e coautores (2003) desenvolveram e validaram uma metodologia analítica por SPE on line e GC/MS. Utilizando matrizes de água superficial (rio Ebro, Catalonia) os autores obtiveram limites de detecção de $8 \mathrm{ng} \cdot \mathrm{L}^{-1}$ e $36 \mathrm{ng} \cdot \mathrm{L}^{-1}$ para $\circ$ ftalato e 0 HPA, respectivamente. $O$ desvio padrão relativo (DPR) do método, sob condições de reprodutibilidade e de repetibilidade, para o DBP foi de 4 e $26 \%(n=3)$ e o 
coeficiente de determinação obtido foi de 0,992 . Para B[a]P o DPR nas mesmas condições do ensaio foi de $1 \%$, e em dias diferentes variou $9 \%(n=3), \circ r^{2}$ alcançado foi de 0,999. Os íons dos ftalatos (dibutil e dietilftalato) foram encontrados em todas as matrizes (água superficial, marinha e efluente).

Liu e colaboradores (2004) desenvolveram um método por SPE-GCMS, seguido de derivatização com BSTFA, para determinação de compostos esteróides e fenólicos em amostras de água e esgoto. Os autores obtiveram as melhores condições de extração quando utilizado o cartucho Oasis $\mathrm{HBL}^{\circledR} \mathrm{e}$ eluição com acetato de etila. A adição de $\mathrm{NaCl}$ promoveu recuperações melhores apenas para o 4-octilfenol e 4-nonilfenol. Já a presença de ácidos húmicos não mostrou influência significativa para o bisfenol $\mathrm{A}$, mas o aumento na concentração das substâncias húmicas diminuiu a recuperação do 4-nonilfenol. $O$ método foi aplicado na Inglaterra, em amostras de efluentes e de água à montante e à jusante do ponto de lançamento. As concentrações mais elevadas foram encontradas no efluente, variando de $<0,8 \mathrm{ng} \cdot \mathrm{L}^{-1}$ a $4 \mathrm{ng} \cdot \mathrm{L}^{-1}$ para o 4-nonilfenol, e entre $9 \mathrm{ng} \cdot \mathrm{L}^{-1}$ a $24 \mathrm{ng} \cdot \mathrm{L}^{-1}$ para o bisfenol $\mathrm{A}$. Nas amostras de água, as concentrações do 4-nonilfenol ficaram abaixo do $L D\left(<0,8 \mathrm{ng} \cdot \mathrm{L}^{-1}\right)$, e as do bisfenol A variaram entre $<\mathrm{LD}\left(5,3 \mathrm{ng} \cdot \mathrm{L}^{-1}\right)$ a $13 \mathrm{ng} \cdot \mathrm{L}^{-1}$.

Brossa et al. (2005) otimizaram metodologia analítica para determinação de HPAs, alquilfenóis, ftalatos e pesticidas empregando extração sortiva em barra de agitação com dessorção líquida e análise por CG/MS. Os autores também investigaram a interferência de diferentes amostras (água doce, marinha e efluente bruto e tratado) sobre o método, constatando pouco efeito das matrizes.

Ésteres de ftalatos foram determinados em amostras de água de torneira e água mineral de Portugal no estudo conduzido por Serôdio e Nogueira (2006) utilizando extração sortiva em barra de agitação e GC/MS. Para os compostos dietilftalato e dibutilftalato, respectivamente, as recuperações foram de 28,8 e 93,6\%, com coeficientes de determinação $\left(r^{2}\right)$ de 0,995 e 0,987, e limites de deteç̧ão alcançados de $15 \mathrm{ng} \cdot \mathrm{L}^{-1}$ e $40 \mathrm{ng} \cdot \mathrm{L}^{-1}$. O resultado encontrado para o DEP na amostra da água de torneira foi de $0,19 \mathrm{ng} \cdot \mathrm{L}^{-1}$ e de $0,04 \mathrm{ng} \cdot \mathrm{L}^{-1}$ na água 
mineral. O DBP apresentou as concentrações mais elevadas dentre todos os ftalatos em ambas as amostras, e foram de $0,52 \mathrm{ng} \cdot \mathrm{L}^{-1}$ na água tratada e de $0,35 \mathrm{ng} \cdot \mathrm{L}^{-1}$ na água engarrafada. Os autores discutem ainda a questão da contaminação por ftalatos, que foi mensurada entre $1 \mathrm{ng} \cdot \mathrm{L}^{-1} \mathrm{e} 15 \mathrm{ng} \cdot \mathrm{L}^{-1}$.

Empregando dois tipos de eluições após a concentração das amostras por SPE Oasis $\mathrm{HBL}^{\circledR}$, Gibson e coautores (2007) avaliaram a presença de ácidos farmacêuticos e disruptores endócrinos em amostras de efluente bruto e água subterrânea da Cidade do México. O método incluiu acidificação da amostra a pH 2, eluição com acetona para a fração rica em DEs, adição de piridina e BSTFA como derivatizantes e análise por GC/MS. As recuperações em níveis baixos e altos de adição padrão foram, respectivamente, de 94 e 101\% para PCP, 105 e 97\% para o BPA e de 108 e 109\% para 4-NP nas amostras de água. Na amostra de efluente, as recuperações foram significativamente menores, especialmente para o PCP - 32\% na fortificação baixa e $27 \%$ na fortificação alta. Tanto nas amostras de esgoto, quanto nas de água, o 4-NP apresentou as concentrações mais elevadas, de $22,4 \mathrm{ng} \cdot \mathrm{L}^{-1}$ e $8 \mathrm{ng} \cdot \mathrm{L}^{-1}$, respectivamente.

O estudo realizado por Zafra-Gómez e colaboradores (2008) teve como foco determinar nonilfenol, bisfenol $A$ e ftalatos em águas residuais urbanas da Espanha com determinação dos disruptores por LC/MS. Dopando a matriz com os analitos, os autores obtiveram valores de recuperação entre 96 e 103\%. BPA e DBP não foram detectados em nenhuma das seis amostras. NP foi encontrado em duas amostras, em concentrações de $0,12 \mu \mathrm{g} \cdot \mathrm{L}^{-1}$ e $0,15 \mu \mathrm{g} \cdot \mathrm{L}^{-1}$, e DEP esteve presente em maior frequência em concentrações entre $0,15 \mu \mathrm{g} \cdot \mathrm{L}^{-1}$ e $0,98 \mu \mathrm{g} \cdot \mathrm{L}^{-1}$.

Sánchez-Avila et al. (2009) investigaram a presença de 16 HPAs, 6 ftalatos, 7 bifenilas policloradas (PCBs), 8 polibromos difenil éteres (PBDEs), 4 alquilfenóis e bisfenol $A$ em amostras de efluente bruto e tratado de áreas urbanas e industriais da Espanha. A concentração de $50 \mathrm{~mL}$ das amostras nãofiltradas ocorreu por SPE, sendo a determinação dos analitos realizada por GC/MS. A média de concentração para o $B[a] P$ no esgoto bruto foi de $0,05 \mu \mathrm{g} \cdot \mathrm{L}^{-1}$, e no esgoto tratado ficou abaixo do $\operatorname{LD}\left(<0,003 \mu \mathrm{g} \cdot \mathrm{L}^{-1}\right)$. A contaminação por NP alcançou concentrações de $102 \mu \mathrm{g} \cdot \mathrm{L}^{-1}$ no efluente bruto e de $21,9 \mu \mathrm{g} \cdot \mathrm{L}^{-1}$ no esgoto 
tratado. Já o BPA apresentou concentrações entre $2,4 \mu \mathrm{g} \cdot \mathrm{L}^{-1}$ e $0,62 \mu \mathrm{g} \cdot \mathrm{L}^{-1}$ nas amostras de esgoto bruto e tratado, respectivamente. DEP e DBP foram mensurados em 50,7 $\mu \mathrm{g} \cdot \mathrm{L}^{-1}$ e $46,8 \mu \mathrm{g} \cdot \mathrm{L}^{-1}$ no efluente bruto. No efluente tratado, a concentração do DEP foi de $49,8 \mu \mathrm{g} \cdot \mathrm{L}^{-1}$, e para o DBP a concentração ficou abaixo do limite de detecção $\left(0,005 \mu \mathrm{g} \cdot \mathrm{L}^{-1}\right)$. Os autores ainda avaliaram a possível contaminação das águas subterrâneas da região, e constataram a presença de todos os cinco compostos acima mencionados, embora abaixo dos limites de detecção.

A presença de isômeros de nonilfenol e estrógenos nas águas destinadas ao abastecimento público de rios da região metropolitana de Belo Horizonte foi avaliada entre 2007 e 2008 por Moreira e colaboradores (2009). Utilizando SPE $\mathrm{C}_{18}$ e LC/MS os autores constataram a presença do NP em todas as amostras de água bruta em concentrações entre $0,044 \mu \mathrm{g} \cdot \mathrm{L}^{-1}$ e $1.918 \mu \mathrm{g} \cdot \mathrm{L}^{-1}$. A análise da água parcialmente tratada (antes da etapa de cloração) demonstrou que a eficiência na remoção do NP nas ETAs é altamente variável, com médias entre 33 e 39\%. Todavia, os autores sugerem cautela nesses resultados, uma vez que não foi respeitado o tempo de retenção hidráulica.

Sodré e coautores (2010) determinaram por LC/MS/MS, dentre outros compostos, bisfenol A e nonilfenol, em amostras de água superficial do rio Atibaia e de efluente bruto do Hospital Universitário de Campinas. Nonilfenol não foi encontrado nas amostras de água e esgoto. O BPA foi detectado em $100 \%$ das amostras, em concentrações entre $25 \mathrm{ng} \cdot \mathrm{L}^{-1}$ e $84 \mathrm{ng} \cdot \mathrm{L}^{-1}$ nas águas superficiais e de $2,5 \mathrm{ng} \cdot \mathrm{L}^{-1}$ na amostra de efluente.

A pesquisa de Diana e Dimitra (2011) investigou a contaminação de diferentes marcas de água mineral por BPA, NP e seis ftalatos (entre eles, DEP e DBP) utilizando extração líquido-líquido e determinação por GC/MS. As autoras analisaram as amostras imediatamente após a compra, e após 15 e 30 dias de estocagem sob condições ambientais (outdoor). BPA, NP, DEP e DBP foram encontradas nas amostras provenientes de garrafas PET (polietileno tereftalato) antes e depois de armazenadas ao sol, porém as concentrações após a exposição não mostrou diferenças estatisticamente significativas. Apenas a 
concentração de BPA da amostra da garrafa de policarbonato aumentou consideravelmente.

\subsection{VALIdAÇÃo de ENSAIO QUÍMICO}

Em química analítica, gerar dados inequívocos, isentos de erros e incertezas é uma tarefa difícil. Contudo, conhecendo-se as características de desempenho de um determinado método, torna-se possível garantir que as medições analíticas realizadas por esse método estejam próximas do valor verdadeiro desconhecido (Moraci, 2008; González e Herrador, 2007).

Para se entender as características de desempenho de um método, este deve passar por um conjunto de verificações que podem ser denominadas de validação de ensaio químico. O principal objetivo da validação é demonstrar que a metodologia aplicada é adequada para sua finalidade, além de conferir confiabilidade e rastreabilidade aos resultados (Mansilha et al., 2010; ICH, 1994).

Atualmente existe uma tendência mundial de que os laboratórios de análises padronizem suas práticas, assegurando um nível comum de qualidade e tornando possível a aceitação internacional de seus resultados. Apesar de não existir uma norma estabelecida para a validação de um ensaio analítico, agências internacionais, como a IUPAC (International Union of Pure and Applied Chemistry), a ICH (International Conference on Harmonization), e a ISO (International Organization for Standardization) definiram parâmetros, requerimentos, e em alguns casos, metodologias para a validação. Em nosso país, as agências credenciadoras que verificam a competência dos laboratórios de ensaios e fornecem diretrizes para o processo de validação são a ANVISA (Agência Nacional de Vigilância Sanitária), por meio da Resolução $\mathrm{n}^{\circ} 899$ de 2003, e o INMETRO (Instituto Nacional de Metrologia, Normalização e Qualidade Industrial), por meio do documento orientativo DOQ-CGCRE-008 (2003, 2007, 2010) (Mansilha et al., 2010; Ribani et al., 2004).

Neste estudo, para a realização dos cálculos estatísticos envolvidos no processo de validação foi utilizada a planilha eletrônica "Validação de Ensaios 
Químicos" desenvolvida por Furusawa (2007). O desenvolvimento dessa ferramenta teve como base o documento DOQ-CGCRE-008 do INMETRO, de 2003 e suas revisões de 2007 e 2010. Os parâmetros de desempenho do método avaliados foram: seletividade/especificidade, linearidade e faixa linear de trabalho, limites de detecção e quantificação, precisão, exatidão, recuperação e robustez, além da incerteza na medição.

\subsubsection{Seletividade/Especificidade}

Os parâmetros seletividade e especificidade estão relacionados ao evento da detecção dos analitos por uma determinada técnica analítica, e frequentemente, a definição desses termos gera algum conflito. Um método seletivo é aquele que produz resposta para vários compostos, mas que pode distinguir a resposta de um analito da de outros. A especificidade em um método é observada quando é produzida resposta para apenas uma substância de interesse. Como existem poucos métodos que geram resposta para apenas um composto, o termo seletividade é mais apropriado (INMETRO, 2003; Lanças, 2004b).

A seletividade deve ser o primeiro parâmetro a ser avaliado no desenvolvimento e validação de uma metodologia, e se esta não for assegurada, a linearidade, a exatidão e a precisão estarão comprometidas. Em técnicas de separação, como as cromatográficas, a seletividade assegura que o pico da resposta observada para uma substância seja exclusivamente do composto de interesse, e em matrizes complexas esta condição é altamente necessária. Os interferentes em uma amostra podem ser provenientes de outros ingredientes ativos, excipientes, impurezas, produtos de degradação, ou ainda, de outros compostos similares que possam estar presentes (Ribani et al., 2004).

\subsubsection{Linearidade e Faixa linear de trabalho}

Quando um método é capaz de fornecer resultados diretamente proporcionais à concentração do analito em questão na amostra, em uma dada 
faixa de concentração, diz-se que o mesmo é linear. A correlação entre o sinal analítico e a concentração da substância representada pela equação da reta é denominada de curva analítica. No gráfico da curva analítica, o eixo da abscissa (x) representa a concentração do analito, e o eixo da ordenada (y), o sinal analítico. Conhecendo-se a relação entre a resposta medida e a concentração da substância de interesse é possível realizar a quantificação de um analito em uma determinada amostra, cuja concentração era inicialmente desconhecida (Moraci, 2008; INMETRO, 2010).

A quantidade de pontos necessária para a confecção de uma curva analítica é variável em função da referência consultada, assim como o número de replicatas (Ribani et al., 2004; Thompson et al., 2002). Todavia, o INMETRO (2010) recomenda no mínimo cinco níveis de concentração, e um número de replicata em cada nível similar ao empregado na rotina do laboratório.

O modelo matemático de regressão linear, determinada pelo método dos mínimos quadrados, pode ser utilizado para estimar os coeficientes da curva analítica (Lanças, 2004b). A equação da reta obtida é descrita na equação 1.

$$
y=a x+b
$$

onde:

y = resposta medida, variável dependente;

x = concentração do analito, variável independente;

a = inclinação da curva analítica (coeficiente angular);

$\mathrm{b}=$ interseção da curva no eixo y (coeficiente linear).

O coeficiente de Pearson, também chamado de coeficiente de correlação (r), é um parâmetro que expressa a relação entre $x$ e $y$, e que permite avaliar a qualidade da curva analítica. Quanto mais próximo da unidade, ou seja, 1 ou -1, menor é a dispersão do conjunto de pontos e menor a incerteza dos coeficientes de regressão. Um coeficiente de correlação igual e 1 indica uma correlação positiva perfeita entre as duas variáveis, enquanto um $r=-1$, significa 
correlação perfeita negativa. Porém, na prática, dificilmente se obtém uma correlação perfeita entre as duas variáveis. Uma relação não linear é observada quando o coeficiente de correlação tender a zero (Leite, 2008; Otomo, 2010).

Da mesma forma, o quadrado do coeficiente de Pearson, denominado de coeficiente de determinação $\left(r^{2}\right)$, pode ser utilizado para estimar a qualidade da curva analítica obtida. $O r^{2}$ pode estar entre zero e 1, entretanto, quanto mais próximo de 1 , menor a dispersão dos valores da curva em relação aos valores esperados para um comportamento linear. O coeficiente de determinação indica a porcentagem de variação explicada ou o ajuste do modelo, por exemplo, se um modelo de regressão apresenta $r^{2}=0,90$, temos o nosso modelo com coeficiente de determinação igual a $90 \%$. Assim, quanto mais próximo de 1 estiver o $\mathrm{r}^{2}$, melhor é o ajuste do modelo (Otomo, 2010). O documento do INMETRO (2003) orienta um coeficiente de correlação acima de 0,90, enquanto a ANVISA (2003) recomenda como critério mínimo aceitável um $r=0,99$.

A análise de resíduos, por meio do teste $t$ (Student) pode ser aplicada para verificar a adequação dos pontos à reta linear, uma vez que desvios de linearidade são difíceis de serem detectados visualmente (INMETRO, 2003). A equação 10 , demonstrada no capítulo 5 , foi utilizada para a análise de resíduos neste estudo.

Como alternativa para a verificação da linearidade, o documento de do INMETRO (2010), sugere a realização da análise da variância (Analysis Of Variance, ANOVA). Esta ferramenta estatística faz uma análise pelos testes $\mathrm{F}$ de regressão e de ajuste. $O$ primeiro verifica a adequação do modelo de regressão adotado aos dados obtidos, com um determinado limite de confiança, enquanto que o segundo (teste $\mathrm{F}$ de ajuste), verifica o quanto esse modelo se ajusta ao conjunto de dados obtidos, com o mesmo limite de confiança. O teste ANOVA ainda faz uma avaliação da porcentagem de variação explicada e da porcentagem máxima de variação explicável (Otomo, 2010).

Em qualquer método instrumental, a faixa linear só é observada em um determinado intervalo de concentração, conhecido como faixa linear dinâmica. A 
faixa de trabalho a ser utilizada deve estar incluída nesta faixa linear abrangendo o intervalo de concentração no qual o método será aplicado, desde que a precisão e a exatidão sejam asseguradas. Sempre que possível, é interessante que a concentração mais esperada do analito na amostra esteja situada aproximadamente no centro da faixa de trabalho. O limite inferior desta faixa é determinado pelo limite de quantificação, já no limite superior a limitação é a resposta produzida pelo equipamento. A IUPAC recomenda que as concentrações da faixa de trabalho devam ser igualmente espaçadas e estar compreendidas na faixa de 0 a $150 \%$ ou de $50 \%$ a $150 \%$ do valor esperado, dependendo que qual for mais adequada (Ribani et al., 2004; Lanças, 2004b; INMETRO, 2003; Thompson et al., 2002).

\subsubsection{Limites de detecção e quantificação}

O limite de deteç̧ão (LD) pode ser entendido como a menor concentração do analito que pode ser distinguido do branco com um determinado limite de confiabilidade, por exemplo, $95 \%$ ou $99 \%$ de confiança (Thompson et al., 2002; INMETRO, 2003). Segundo Ribani e coautores (2004), o LD pode ser calculado pela relação sinal-ruído, onde as proporções 3:1 ou 2:1 são geralmente aceitas, ou pelos parâmetros da curva, onde o limite de detecção é estimado pela multiplicação de 3 vezes o desvio padrão da resposta (3s), dividido pelo coeficiente angular da reta ou inclinação.

O limite de quantificação (LQ) representa a menor quantidade do analito que pode ser quantificado com segurança, ou seja, com um nível aceitável de exatidão e precisão. Da mesma forma como o LD, o LQ pode ser calculado pela relação sinal-ruído, porém, utiliza-se a proporção 10:1. O limite de quantificação pode ainda ser mensurado pelo branco da amostra mais 5,6 ou 10 desvios padrão (Ribani et al., 2004; INMETRO, 2010).

Os limites de detecção e de quantificação, neste estudo, foram estimados pelas equações 11 e 12, apresentadas no capítulo 5 . 


\subsubsection{Precisão}

Por meio da precisão do método analítico avalia-se a dispersão de resultados entre ensaios independentes, repetidos em uma mesma amostra, amostras semelhantes ou padrões sob condições pré-estabelecidas. É usualmente expressa em termos de desvio padrão (DP) e desvio padrão relativo (DPR), também conhecido como coeficiente de variação (CV), como mostra a equação 2 (INMETRO, 2003; Thompson et al., 2002).

$$
\operatorname{DPR}(\%) \text { ou } C V(\%)=\left(\frac{s}{\bar{x}}\right) x 100
$$

onde:

$\mathrm{s}=$ desvio padrão das medições

$\overline{\mathrm{x}}=$ média aritmética das mesmas determinações

O valor aceitável do coeficiente de variação depende do nível de concentração analisada e da complexidade da matriz considerada. Horwitz e Albert (2006) mencionam um DRP aceitável de até $20 \%$ em análises de traço ou impurezas.

A precisão pode ser avaliada em termos de repetitividade, reprodutibilidade e precisão intermediária. Embora as condições da análise sejam distintas, os três níveis investigam a dispersão dos resultados em amostras medidas sequencialmente. Quanto menor a amplitude de variação das medidas, maior a precisão do método (Leite, 2008).

A repetitividade tem como finalidade avaliar se os resultados se repetem ou se distribuem aleatoriamente, nas mesmas condições de análise e em um curto intervalo de tempo. Essas condições são chamadas de condições de repetitividade, e incluem: mesmo procedimento, mesmo analista, mesmas condições do equipamento/instrumento e no mesmo laboratório (Leite, 2008; INMETRO, 2010). 
Quando a medição de uma mesma amostra ou padrão é realizada pelo próprio laboratório, utilizando o mesmo método, porém variando-se o analista, o equipamento e em tempos diferentes (dias, por exemplo), se está avaliando a precisão intermediária. Esta avaliação é mais representativa da variabilidade dos resultados fornecidos por um único laboratório, e garante que o mesmo procedimento fornecerá resultados iguais (INMETRO, 2010; Ribani et al., 2004).

Enquanto a repetitividade é estabelecida por ensaios intralaboratoriais, a reprodutibilidade refere-se à precisão interlaboratorial, e deve ser avaliada por estudos colaborativos, como em ensaios de proficiência. $\mathrm{Na}$ reprodutibilidade, embora se avalie a concordância entre os resultados de uma mesma amostra, as condições de análise são variadas, uma vez que o local, o instrumento e o analista são diferentes (Lanças, 2004b; Leite, 2008).

\subsubsection{Exatidão}

A exatidão representa o grau de concordância entre o valor mensurado em um ensaio e o valor de referência aceito como verdadeiro. Para se investigar a exatidão de um método podem ser utilizados materiais de referência certificados $(\mathrm{MRC})$, comparação entre métodos, ensaios de recuperação ou adição padrão (Ribani et al., 2004).

Os MRC, sempre que possível, devem ser utilizados no processo de validação de um método, pois são materiais rastreáveis fornecidos por instituições reconhecidas internacionalmente que acompanham um certificado com o valor de concentração de uma substância ou outra grandeza para cada parâmetro e a incerteza associada (INMETRO, 2010).

Na comparação entre métodos, a mesma amostra é analisada em replicatas utilizando-se o procedimento desenvolvido e um método de referência. O método da adição padrão é aplicável quando não é possível obter uma amostra livre da substância de interesse (INMETRO, 2003). O ensaio de recuperação é o mais usual e será detalhado no item 3.8.6. 
Os cálculos que podem ser utilizados para verificação da exatidão são: erro relativo e normalizado, teste de hipótese, índice z (z Score). Neste estudo, foi considerado o índice $z$, onde o cálculo é demonstrado na equação 15 do capítulo 5 dessa dissertação.

\subsubsection{Recuperação}

A recuperação consiste na proporção da quantidade da substância de interesse, presente ou adicionada à amostra, que o método consegue extrair e é possível quantificar. Na prática o estudo de recuperação é realizado por meio de spike, isto é, adicionando-se concentrações conhecidas do analito na amostra (Ribani et al., 2004; Thompson et al., 2002).

A limitação deste procedimento decorre do fato de que o analito adicionado normalmente não está na mesma forma que quando presente na amostra in natura, mas sim se apresentará em uma forma mais facilmente detectável, o que pode resultar em uma avaliação otimista da recuperação. Três níveis de concentração devem ser escolhidos para os ensaios de recuperação, e estes devem abranger a faixa de uso do método (INMETRO, 2010). Segundo Ribani et al. (2004), em análise de resíduos o intervalo de recuperação aceitável varia de 70 a $120 \%$, ou ainda, de 50 a $120 \%$ para amostras mais complexas. O cálculo da recuperação é realizado de acordo com a equação 3.

$$
R(\%)=\left(\frac{C_{1}-C_{2}}{C_{3}}\right) \times 100
$$

onde:

$\mathrm{C}_{1}=$ concentração determinada na amostra com adição do padrão;

$\mathrm{C}_{2}=$ concentração determinada na amostra sem adição do padrão;

$\mathrm{C}_{3}=$ concentração do padrão adicionado 


\subsubsection{Robustez}

A robustez avalia a capacidade do método em fornecer os mesmos resultados mesmo quando as condições experimentais sofrem pequenas variações. Quanto mais robusta for a metodologia, maior será a segurança em relação a sua precisão (Thompson et al., 2002; INMETRO, 2003).

Os parâmetros selecionados para verificar a sensibilidade do método devem ser escolhidos levando-se em consideração os que, possivelmente, tenham mais influência sobre os resultados. Dessa forma, em análises cromatográficas, por exemplo, pode-se avaliar a composição ou $\mathrm{pH}$ da fase móvel, gradiente de temperatura, diferentes marcar de colunas, natureza do gás de arraste, entre outros (Ribani et al., 2004).

Para determinação da robustez o INMETRO (2003) recomenda a execução do teste de Youden, onde é possível conhecer além da robustez do método, a influência de cada uma das variações no resultado final de forma ordenada. Neste estudo foi utilizado o Planejamento Fracionário Saturado, onde sete parâmetros são selecionados e agrupados em uma combinação fatorial, resultando em oito experimentos distintos. A combinação a ser ensaiada pode ser observada na TAB. 3. As letras maiúsculas indicam os valores nominais dos parâmetros, e as minúsculas, suas variações.

TABELA 3. Planejamento fatorial saturado para avaliação da estimativa do erro da distribuição dos efeitos utilizando 0 algoritmo de Dong (pequenos experimentos).

\begin{tabular}{|c|c|c|c|c|c|c|c|c|}
\hline \multirow{2}{*}{$\begin{array}{l}\text { Valor do } \\
\text { fator }\end{array}$} & \multicolumn{8}{|c|}{ Combinação ensaiada } \\
\hline & 1 & 2 & 3 & 4 & 5 & 6 & 7 & 8 \\
\hline A ou a & $A$ & $A$ & $A$ & $A$ & $\mathrm{a}$ & $\mathrm{a}$ & $a$ & $\mathrm{a}$ \\
\hline B ou b & $\mathrm{B}$ & $\mathrm{B}$ & $\mathrm{b}$ & $b$ & $\mathrm{~B}$ & B & $\mathrm{b}$ & $b$ \\
\hline C ou c & C & $\mathrm{c}$ & C & $\mathrm{c}$ & C & c & $\mathrm{C}$ & c \\
\hline D ou d & $\mathrm{D}$ & $\mathrm{D}$ & $d$ & $d$ & $d$ & $d$ & $\mathrm{D}$ & $\mathrm{D}$ \\
\hline E ou e & $E$ & e & $E$ & $\mathrm{e}$ & $\mathrm{e}$ & $E$ & e & $E$ \\
\hline F ou $f$ & $\mathrm{~F}$ & $f$ & $f$ & $\mathrm{~F}$ & $\mathrm{~F}$ & $f$ & $f$ & $\mathrm{~F}$ \\
\hline G ou g & $\mathrm{G}$ & $g$ & $g$ & $G$ & $g$ & G & $\mathrm{G}$ & $g$ \\
\hline Resultado & $s$ & $t$ & $u$ & $v$ & $w$ & $x$ & $y$ & $z$ \\
\hline
\end{tabular}

Fonte: INMETRO (2003). 


\subsubsection{Incerteza de medição}

A qualidade de um resultado emitido por uma metodologia analítica está intimamente relacionada às incertezas das medidas envolvidas no processo. Cada medida considerada possui uma incerteza associada, proveniente de erros originados em cada estágio da análise (Guia CITAC/EURACHEM, 2002).

A definição do termo incerteza de medição adotada pelo Guia EURACHEM (2002) é dada como "um parâmetro associado ao resultado de uma medição, que caracteriza a dispersão de valores que poderiam ser razoavelmente atribuídas ao mensurando". A declaração da incerteza nada mais é do que a estimativa (quantitativa) dos limites dentro dos quais os desvios do valor de um mensurando são previstos de se situar. Pode ser expressa como um desvio padrão ou um múltiplo deste (Guia CITAC/EURACHEM, 2002).

Uma grande variedade de fatores torna $\circ$ resultado da medição analítica possível de se desviar do valor verdadeiro. A medição analítica é denominada de mensurando, ou grandeza de saída, e pode ser entendido como $o$ objeto da medição, ou seja, o resultado que se pretende obter. Os fatores que constituem 0 mensurando são as grandezas de entrada (Guia CITAC/EURACHEM, 2002; INMETRO, 2010b).

As fontes de incerteza que atuam sobre as grandezas de entrada devem ser identificadas e a elas atribuídas um valor, sendo possível então quantificar a contribuição de cada uma, e após serem combinadas, obter-se um valor global que atue sobre o resultado. $\mathrm{Na}$ identificação das fontes de incerteza todas as etapas do processo devem ser avaliadas, como por exemplo, amostragem, armazenamento e preparação das amostras, calibração do instrumento, pureza de reagentes, efeito da amostra e do analista, entre outros (Guia CITAC/EURACHEM, 2002; Guia EURACHEM, 2002).

Dois métodos de avaliação das incertezas associadas a uma grandeza de entrada podem ser distinguidos. Para incertezas do Tipo $A$, a determinação ou análise estatística baseia-se em uma série de observações ou medidas. Neste 
caso, a incerteza padronizada é o desvio padrão experimental da média. No segundo método, para incertezas do Tipo B, a avaliação da incerteza padronizada é obtida por outros meios que não o desvio padrão, como por exemplo, certificados emitidos pelo fabricante, materiais de referência certificados, manuais técnicos, entre outros (INMETRO, 2010b; Leite, 2008).

Como mencionado anteriormente, para se obter a incerteza total do mensurando $(y)$, as fontes de incerteza devem ser trabalhadas individualmente, obtendo-se a contribuição de cada componente. Quando o componente de incerteza é expresso como um desvio padrão, o mesmo é denominado de Incerteza Padronizada, $u\left(x_{i}\right)$. A combinação de todos os componentes da incerteza resulta na Incerteza Combinada, $u_{c}(y)$, sendo esta um desvio padrão calculado pela raiz quadrada positiva da variância total. Porém, para se obter um intervalo, com alto nível de segurança, onde se acredite que esteja o valor do mensurando, é necessário a estimativa da Incerteza Expandida, U. Esta é calculada multiplicando-se a incerteza combinada, $u_{c}(y)$ por um fator de abrangência, $k$. $O$ valor de $k$ está relacionado ao nível de confiança que se deseja atribuir, por exemplo, para um nível de confiança de aproximadamente 95\%, k é igual a 2 (Guia EURACHEM, 2002).

No esquema da FIG. 9 estão representadas as etapas envolvidas na estimativa da incerteza de uma medição analítica.

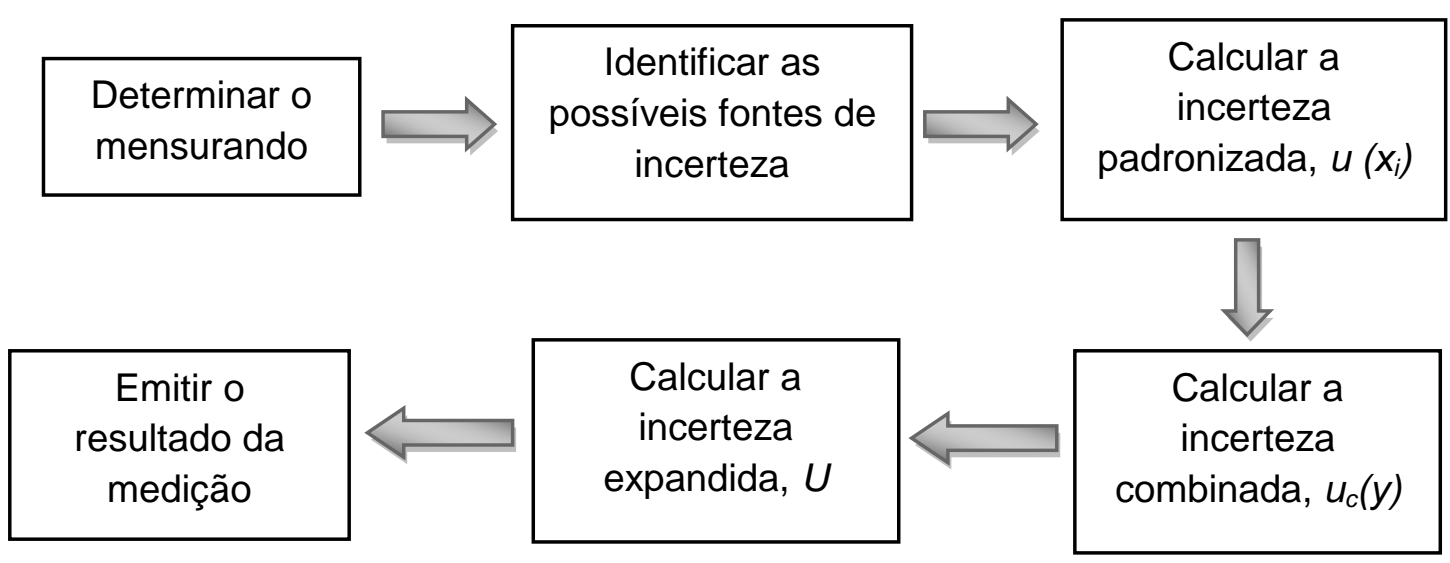

FIGURA 9. Etapas envolvidas no processo de estimativa de incerteza (adaptado de Leite, 2008). 


\subsubsection{Diagrama de Causa e Efeito (Ishikawa ou Espinha de peixe)}

A estruturação das fontes de incerteza em um diagrama, denominado de Diagrama de Causa e Efeito possibilita identificar, simplificar e agrupar todas as incertezas envolvidas no processo, evitando possíveis duplicações (Guia EURACHEM, 2002).

Na FIG. 10 é apresentado o Diagrama de Causa e Efeito para a metodologia desenvolvida para a análise dos xenoestrógenos em amostras de água bruta e potável. As principais fontes de incerteza identificadas foram as associadas à curva analítica, ao fator de recuperação e ao volume final do extrato. A cada uma destas fontes de incerteza principais estão relacionadas outras fontes de incerteza de entrada. As equações envolvidas na estimativa da incerteza são demonstradas no item 5.4 .9 do capítulo 5 desta dissertação. 


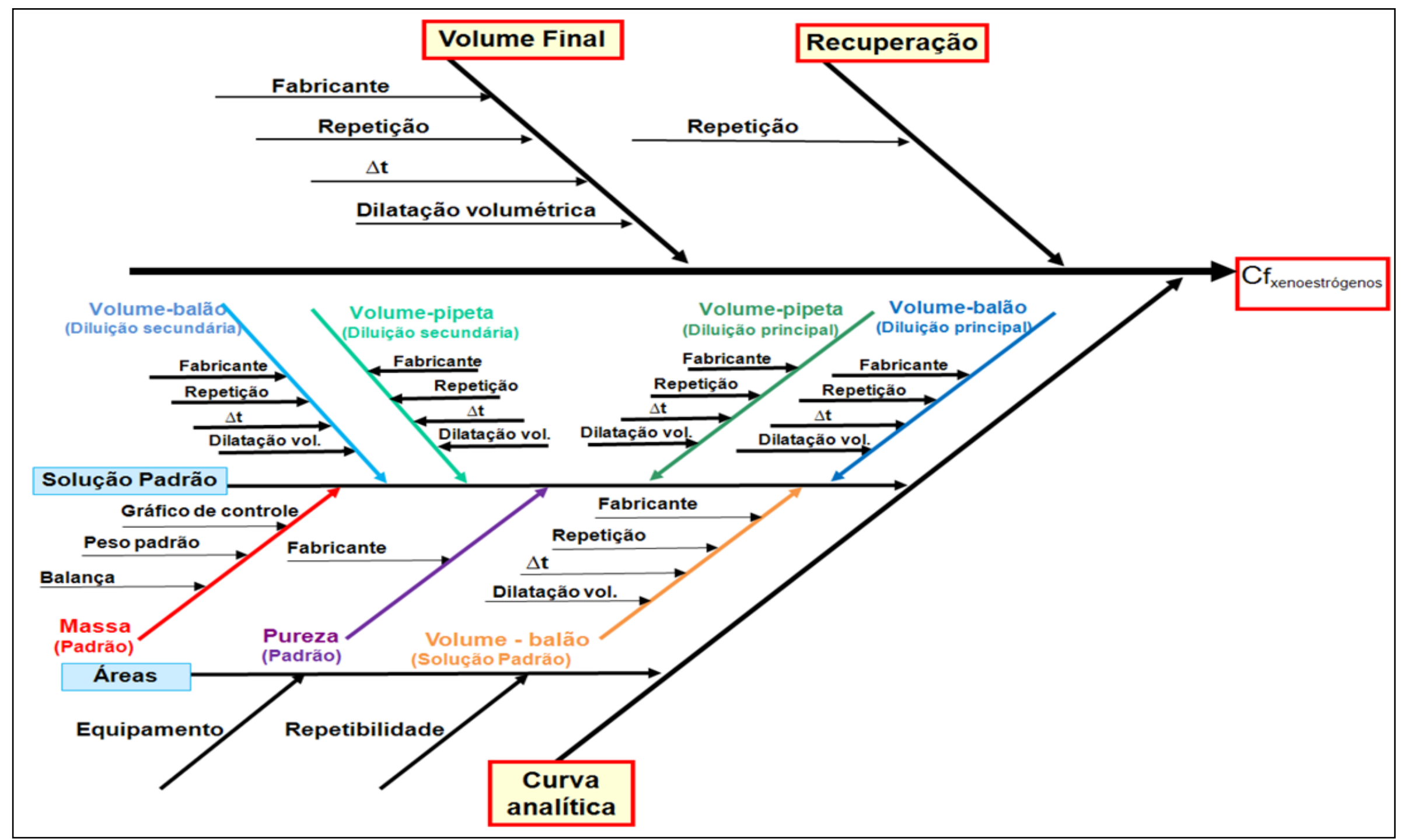

FIGURA 10. Diagrama de Causa e Efeito da metodologia desenvolvida para análise de xenoestrógenos em água. 


\section{4. ÁREA DE ESTUDO}

O Brasil é um dos países com maior disponibilidade de água doce do mundo. Nossos recursos hídricos superficiais representam $50 \%$ do total de recursos da América do Sul e $11 \%$ dos recursos mundiais. Entretanto, a distribuição da água pelo território brasileiro e durante o ano não é uniforme, como exemplo, temos grande volume de água na bacia Amazônica e as limitações de disponibilidade na região Nordeste (Tucci et al., 2001).

A criação da Lei 9.433 em 1997, mais conhecida como Lei das Águas, foi um importante agente para a gestão das águas brasileiras, uma vez que instituiu a Política Nacional dos Recursos Hídricos e criou o Sistema Nacional de Gerenciamento de Recursos Hídricos. A partir da aprovação desta lei, o país foi dividido em bacias hidrográficas, ou Unidades de Gerenciamento de Recursos Hídricos (UGRHI), que são administradas pelos Comitês das Bacias e pela Agência de Água (Porto e Porto, 2008).

O estado de São Paulo é composto por 22 Unidades de Gerenciamento de Recursos Hídricos e em sete regiões hidrográficas, como podem ser observadas na FIG 11. Segundo o relatório emitido pela Companhia Ambiental do Estado de São Paulo - CETESB (2010), a UGRHI 2 Paraíba do Sul está inserida em uma área industrializada, juntamente com as Unidades 5 (Piracicaba, Capivari, e Jundiaí), 6 (Alto Tietê), 7 (Baixada Santista) e 10 (Sorocaba/Médio Tietê).

A área onde foi realizado este estudo é a Bacia Hidrográfica do Paraíba do Sul (FIG. 12), localizada na região sudeste do país, com aproximadamente $55.400 \mathrm{~km}^{2}$, abrange os estados de São Paulo $(24,5 \%)$, na região denominada de Vale do Paraíba Paulista, quase metade do estado do Rio de Janeiro (38\%) e a zona da Mata Mineira, em Minas Gerais (37,5\%). Embora a Bacia Hidrográfica do Paraíba do Sul represente apenas $0,7 \%$ do território brasileiro e $6 \%$ da região 
sudeste, a mesma está localizada em uma das áreas mais industrializadas do Brasil, responsável por aproximadamente $12 \%$ do PIB do país. A bacia engloba um total de 184 municípios, dos quais 88 estão em Minas Gerais, 39 no estado de São Paulo e 57 no estado do Rio de Janeiro (Pereira, 2003; AGEVAP, 2009).

A gestão da Bacia Hidrográfica do Paraíba do Sul está sob a responsabilidade do Comitê de Integração da Bacia Hidrográfica do Rio Paraíba do Sul (CEIVAP) e da Agência da Bacia do Rio Paraíba do Sul (AGEVAP). No mapa da FIG. 12 são apresentados os limites desta bacia, assim como os Comitês que atuam na região. Como pode ser visto, a gestão do trecho paulista está sob controle do Comitê das Bacias Hidrográficas do Rio Paraíba do Sul (CBH-PS) ou "Comitê Paulista", o primeiro a ser implementado na área do Paraíba do Sul (Braga et al., 2008).

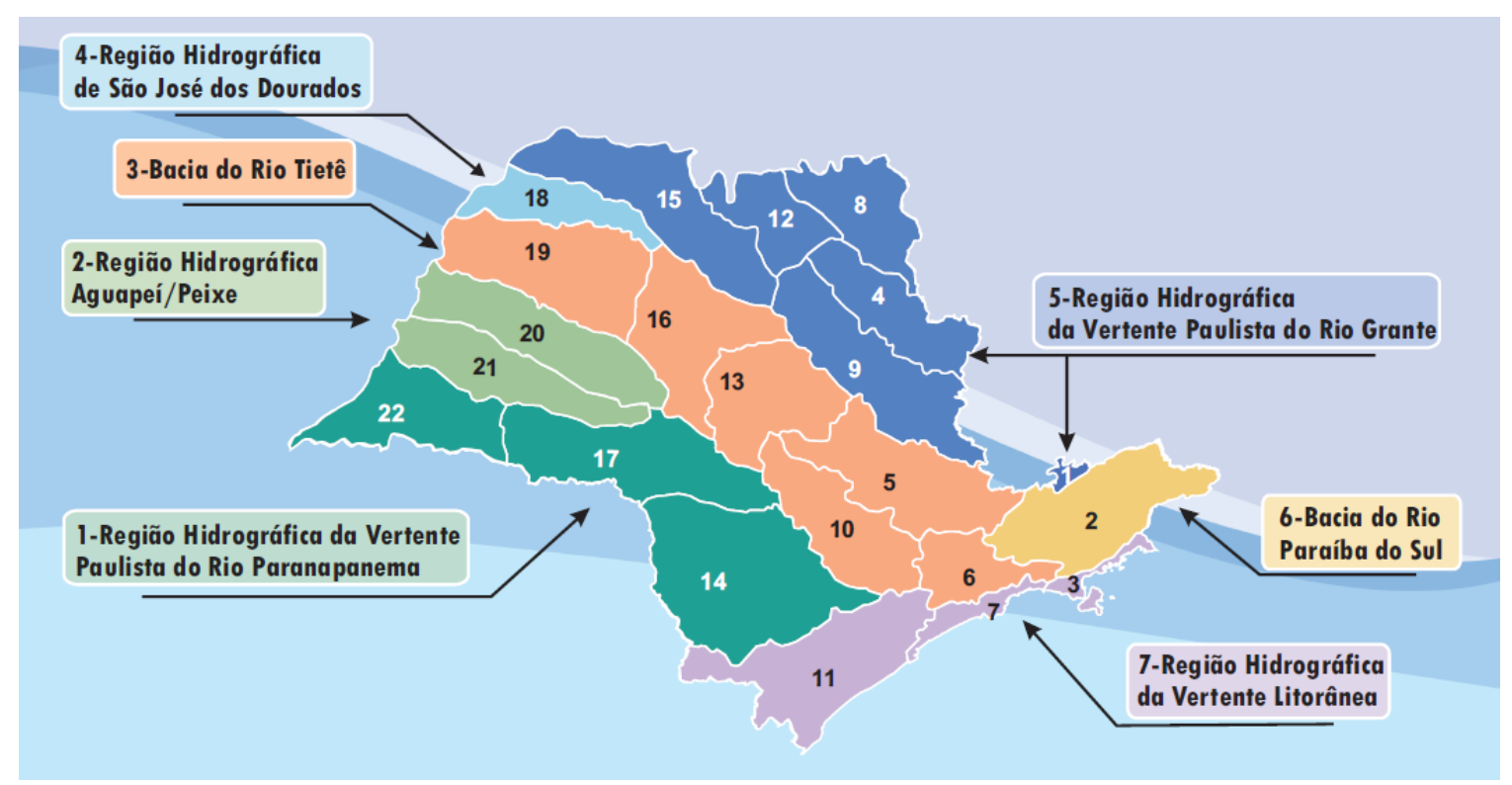

FIGURA 11. Unidades de Gerenciamento de Recursos Hídricos do estado de São Paulo (SIGRH, 2011). 


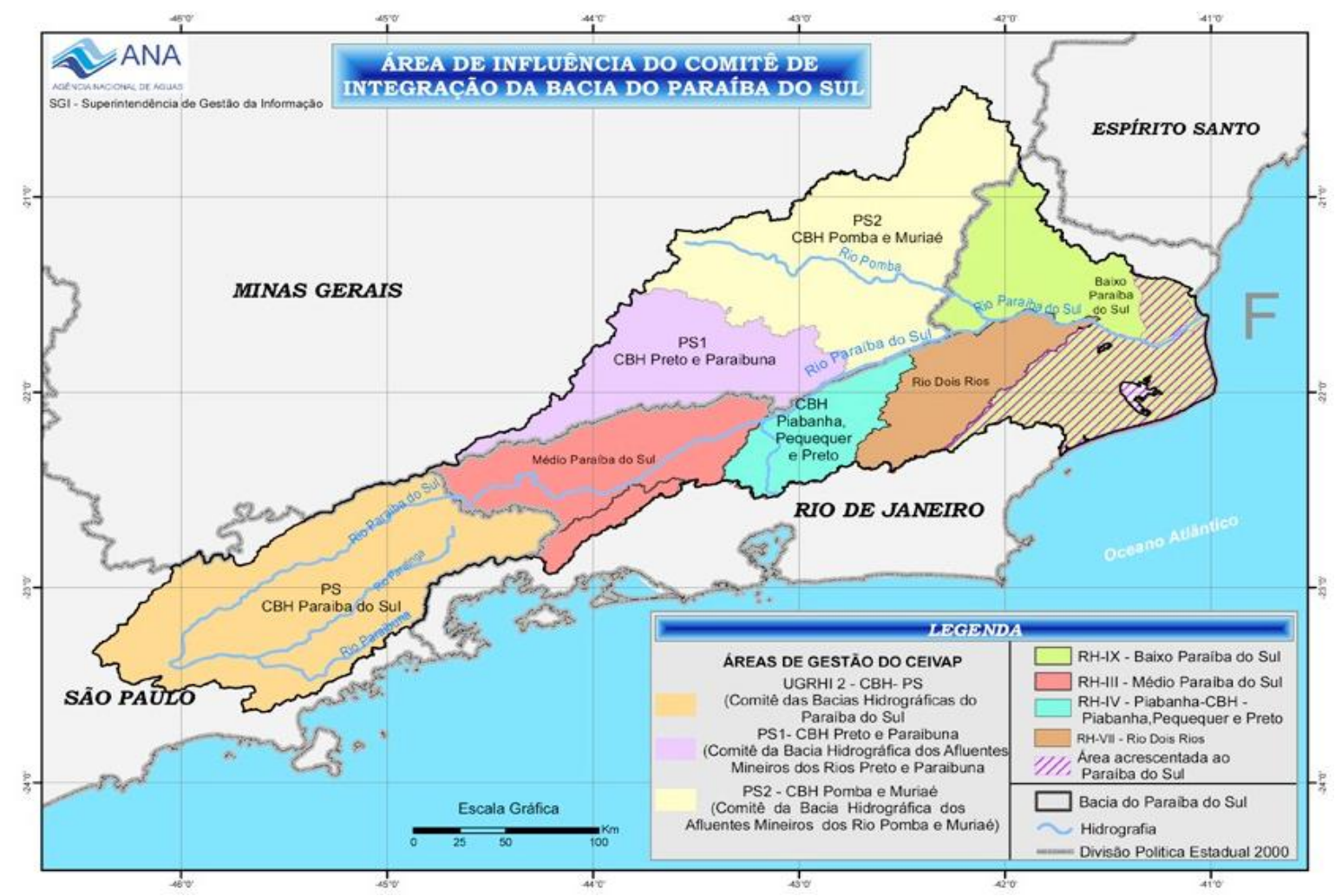

FIGURA 12. Área de abrangência da Bacia hidrográfica do rio Paraíba do Sul. (CEIVAP-AGEVAP, 2009).

O vale do rio Paraíba do Sul distribui-se na direção leste-oeste entre a Serra do Mar e da Mantiqueira, no bioma de Mata Atlântica, que originalmente se estendia por toda a costa brasileira, mas que em função do desmatamento, atualmente restringe-se somente a $11 \%$ da sua área total em regiões mais elevadas e de relevo acidentado. A região é uma das poucas áreas de relevo montanhoso do país, com colinas e montanhas de mais de 2.000 metros, onde o ponto culminante é o Pico das Agulhas Negras (com 2.787 metros), no Rio de Janeiro. O clima predominante é o quente e úmido, com variações causadas pela entrada de ventos marinhos e diferenças de altitude (Gruben et al., 2002; AGEVAP, 2009).

O rio Paraíba do Sul forma-se na cidade de Paraibuna (SP) pela junção dos rios Paraitinga e Paraibuna, percorrendo uma distância de $1.150 \mathrm{~km}$ até desaguar no oceano Atlântico, no norte fluminense. Os principais afluentes à direita são os rios Piraí, Piabanha e Dois Rios e, à margem esquerda tem-se os rios Paraibuna, Pomba e Muriaé. A bacia hidrográfica do Paraíba do Sul tem como limite ao norte a Serra da Mantiqueira e ao sul a Serra do Mar. A leste, a 
bacia confronta-se com a bacia do rio Itabapoana, e a oeste com a bacia do rio Tietê (AGEVAP, 2009; FCR, 2009).

Até meados do século XX a população da bacia do rio Paraíba do Sul era predominantemente rural, devido à ocupação inicial da bacia pelo ciclo do café. Porém, com a decadência do cultivo cafeeiro e de cana-de-açúcar e a instalação da Companhia Siderúrgica Nacional (CSN) em 1946, no trecho fluminense, iniciou-se um intenso processo de urbanização e de criação de gado. Atualmente, a pecuária ocupa aproximadamente $70 \%$ no território da bacia, a agricultura representa $27 \%$ da cobertura vegetal e $11 \%$ são de florestas nativas, encontradas especialmente na Serra dos Órgãos e nos parques nacionais da Serra da Bocaina e de Itatiaia (Gruben et al., 2002; CEIVAP e AGEVAP, 2009).

Como atividade do setor primário de maior importância econômica na região, encontra-se a criação de gado leiteiro em regime extensivo, embora ainda cultiva-se cana-de-açúcar e café e, em menor escala, a produção de eucaliptos e pinheiros. O setor industrial é altamente diversificado e conta com 7.000 estabelecimentos, desde indústrias metalúrgicas até empresas de papel e celulose. Apenas no trecho paulista, em 2002, haviam registradas na CETESB 2500 empresas, dentre as quais, 19 indústrias químicas, 26 metalúrgicas e siderúrgicas, 4 empresas de material elétrico e eletrônico, 1 petroquímica e 3 indústrias de papel e celulose. A parte mais crítica da bacia em função das atividades industriais é o trecho fluminense, porém a situação não é diferente no trecho mineiro (Marengo e Alves, 2005; Gruben et al., 2002).

Apesar de grande área da bacia do Paraíba do Sul ser ocupada pela atividade pecuária, esta está em último lugar quando se trata do consumo de água, em termos de volume de captação. A maior demanda do recurso hídrico ocorre pelo setor agrícola, principalmente para irrigação das culturas de arroz e cana-de-açúcar, em seguida tem-se o abastecimento público e a utilização pelas indústrias (Pereira, 2003; Gruben et al., 2002).

Segundo o censo demográfico de 2000, a bacia do Paraíba do Sul apresentava uma população de 5,5 milhões de habitantes, dos quais $89 \%$ viviam 
em áreas urbanas. Desta população, 2,4 milhões de pessoas residiam no lado fluminense da bacia, 1,3 milhões moravam em Minas Gerais e 1,8 milhões de pessoas estavam em São Paulo. Essas populações representam, respectivamente, $16 \%$ da população fluminense, $7 \%$ dos mineiros e apenas $5 \%$ dos paulistas (Pereira, 2003; CEIVAP e AGEVAP, 2009).

O potencial hídrico do rio Paraíba do Sul é aproveitado para a geração de energia elétrica, abastecimento público, uso industrial e agrícola, além de corpo receptor de efluentes. Seu potencial para pesca, lazer e turismo é pouco explorado, embora exista capacidade para desenvolvimento. Pela transposição das águas do Paraíba do Sul para o rio Guandu criou-se uma grande oferta hídrica para o abastecimento da Região Metropolitana do Rio de Janeiro e para a alimentação de hidroelétricas da região. Estima-se que aproximadamente 14,2 milhões de pessoas sejam abastecidas pelas águas da bacia do Paraíba do Sul, incluindo mais de 8 milhões de habitantes que estão situados fora dos limites da bacia (Pereira, 2003; CEIVAP e AGEVAP, 2009).

Segundo Paixão (2009), é alto o índice da população atendida pelo abastecimento de água na região do Paraíba do Sul. Embora a porcentagem varie entre os municípios, $94,6 \%$ das cidades paulistas inseridas na bacia contam com sistema de abastecimento de água. No trecho mineiro, 95\% da população dispõem deste serviço de saneamento, e no Rio de Janeiro o sistema cobre $88 \%$ dos habitantes.

O desenvolvimento descontrolado das atividades agropecuárias e urbano-industriais acarretou problemas ambientais no entorno na bacia, como a redução da floresta nativa pelo intenso desmatamento, a contaminação das águas por efluentes domésticos e industriais, a erosão das margens do rio Paraíba e de seus afluentes, e o esgotamento da capacidade produtiva dos solos da região. No momento, a escassez do recurso hídrico da bacia é um problema relacionado mais à qualidade das águas do que à quantidade disponível, embora em algumas regiões mais devastadas observa-se a diminuição da quantidade de água (Pereira, 2003; Marengo e Alves, 2005). 
Por tratar-se de uma área com alto índice de urbanização e industrialização, a bacia do rio Paraíba do Sul está sujeita à constante pressão devido às atividades antrópicas que comprometem a qualidade do recurso hídrico, principalmente, em função da descarga de efluentes domésticos e industriais. $O$ saneamento básico na região necessita de maiores investimentos nos três estados abrangidos pela bacia, uma vez que, os índices de coleta e tratamento de esgotos, diferentemente das taxas de abastecimento público, são reduzidos, como pode ser observado na TAB. 4.

TABELA 4. Índices de coleta e tratamento de esgoto na região pertencente à bacia do Paraíba do Sul dos três estados.

\begin{tabular}{cccc}
\hline & São Paulo & Minas Gerais & Rio de Janeiro \\
\hline Coleta de esgoto (\%) & 89,9 & 93,1 & 69,6 \\
Tratamento de esgoto (\%) & 32,3 & 12,0 & 7,6 \\
\hline
\end{tabular}

Fonte: Paixão, 2009.

Segundo a CETESB (2010) a porcentagem da população atendida pela coleta de esgotos na UGRHI 2 (Paraíba do Sul) é de 89\%, e o índice de tratamento chega a 48\%. Embora seja um percentual mais alto do que 0 mencionado por Paixão (2009), este ainda pode ser considerado baixo.

O volume de esgoto sanitário descartado no rio Paraíba do Sul é de aproximadamente um bilhão de litros por dia segundo o relatório da CEIVAP de 2008-2009. A carga poluidora orgânica é de aproximadamente 280 toneladas de DBO (demanda bioquímica de oxigênio) por dia, dos quais estima-se que $86 \%$ seja proveniente de efluentes domésticos e $14 \%$ de efluentes industriais (CEIVAP e AGEVAP, 2009).

\subsection{MunicíPIOS DE INTERESSE}

Para a realização desta pesquisa, foram coletadas amostras em quatro municípios localizados no trecho paulista da bacia hidrográfica do Paraíba do Sul: Guararema, São José dos Campos, Taubaté e Pindamonhangaba. A divisão territorial dos 39 municípios paulistas que pertencem à bacia, e as cidades escolhidas podem ser visualizadas na FIG. 13. 


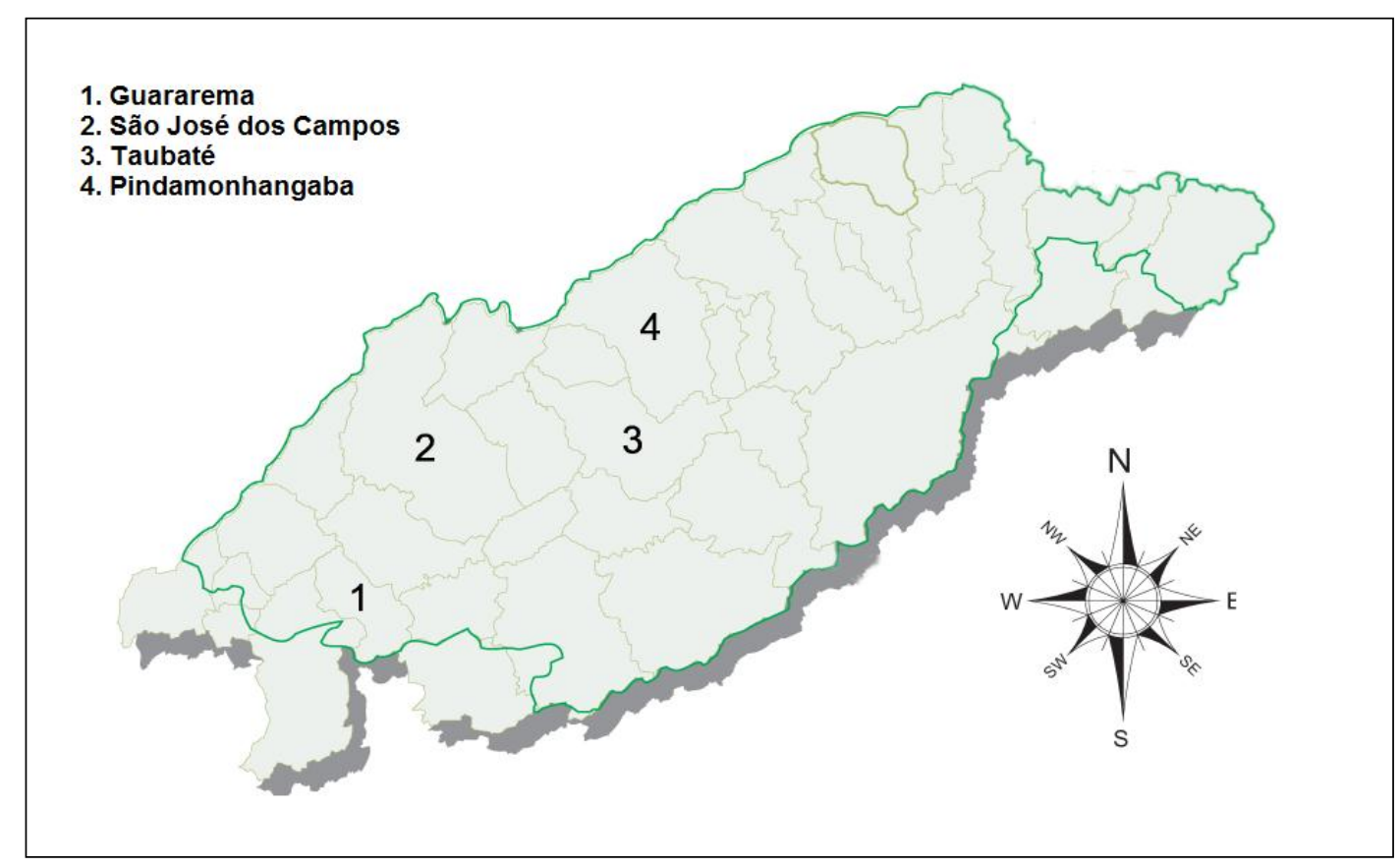

FIGURA 13. Divisão territorial dos municípios localizados no trecho paulista da bacia hidrográfica do rio Paraíba do Sul, em destaque os quatro municípios de interesse.

\section{GUARAREMA}

Dentre os quatro municípios que compõem a área de estudo, a cidade

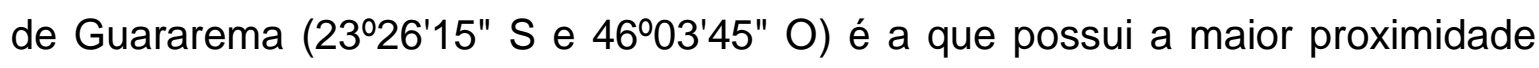
com a capital do estado, estando localizada a apenas $88 \mathrm{~km}$ de São Paulo. Com uma área de $270,5 \mathrm{~km}^{2}$, a pequena Guararema conta com uma população de 25.861 habitantes, dos quais $86 \%$ vivem na área urbana, segundo o censo demográfico de 2010. Na cidade, estavam instaladas no ano de 2008, 70 indústrias com 2.258 postos de trabalho. A coleta de esgoto no município atinge $70 \%$ das habitações. Deste percentual, 35\% recebem tratamento, e têm como corpo receptor o rio Paraíba do Sul (IBGE, 2010; FCR, 2009; CETESB, 2010).

\section{SÃO JOSÉ DOS CAMPOS}

Dos municípios paulistas com sede na bacia hidrográfica do Paraíba do

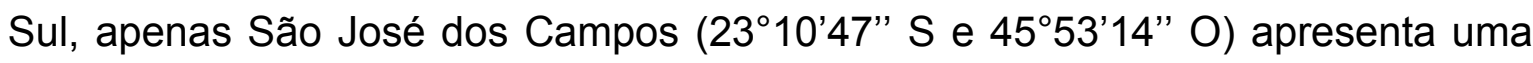
população superior a 500 mil habitantes, sendo o número de habitantes em 2010 de 627.544 pessoas, com 98\% residindo na zona urbana. A cidade possui território com $1.100 \mathrm{~km}^{2}$, e está localizada a $97 \mathrm{~km}$ da capital São Paulo (São José dos Campos, 2011; IBGE, 2010). 
Situada entre as maiores metrópoles do país, Rio de Janeiro e São Paulo, a cidade é a mais fortemente industrializada entre os municípios de interesse, com empresas de diferentes segmentos, desde o alimentício até o aeronáutico. Segundo FCR (2009), em 2008 haviam instaladas 827 indústrias em São José dos Campos, gerando mais de 53 mil empregos. O município coleta $88 \%$ do esgoto gerado, mas trata apenas $46 \%$, e é responsável pela maior carga remanescente de DBO entre os municípios que compõem a UGRHI 2, com $21.351 \mathrm{~kg} \mathrm{DBO} / \mathrm{dia}$. Os corpos receptores são os rios Paraíba, Cambuí, Peixe, Alambari e Pararangaba (CETESB, 2010).

\section{$\underline{\text { TAUBATÉ }}$}

Com um território de $625 \mathrm{~km}^{2}$, o município de Taubaté (2301'25" S e 4533'30" O) está localizado a 130 km de São Paulo, e possui uma população de 278.724 habitantes, com população rural de apenas 6 mil indivíduos ( $2 \%$ da população total). A cidade tinha registrado em 2008, 396 indústrias, e contava com 21.592 postos de trabalho. A atividade industrial representa $73 \%$ da economia local. A eficiência no saneamento básico em relação ao tratamento de esgoto é de $90 \%$, com $92 \%$ do efluente gerado coletado e totalmente tratado (Taubaté, 2011; FCR, 2009; IBGE, 2010; CETESB, 2010).

\section{PINDAMONHANGABA}

Localizada a $140 \mathrm{~km}$ da capital do estado, Pindamonhangaba

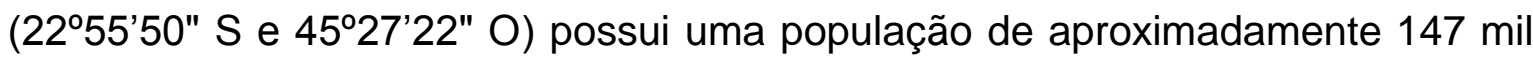
habitantes, com mais de $90 \%$ dos moradores residindo em zona urbana. A área territorial é de $731 \mathrm{~km}^{2}$. Com quase 12 mil postos de emprego distribuídos entre as 246 indústrias do município, a atividade industrial é o principal setor da economia. Assim como em Taubaté, a cidade de Pindamonhangaba trata 100\% do esgoto coletado, estando este serviço disponível em $93 \%$ das residências. $O$ efluente tratado tem como destino final as águas dos rios Paraíba, Una e Ribeirão Uruputuba (Pindamonhangaba, 2011; IBGE, 2010; FCR, 2009; CETESB, 2010). 


\section{PARTE EXPERIMENTAL}

Para alcançar o objetivo desta pesquisa, o de determinar compostos disruptores endócrinos de origem industrial em amostras de água utilizando as técnicas de SPE e GC/MS, a etapa experimental foi dividida em três fases. Na primeira, otimizou-se a análise cromatográfica e o procedimento para extração dos analitos, baseando-se nos dados disponíveis na literatura (Mol, 2000; Hernando, 2004; Moreira, 2008). Sequencialmente, os parâmetros da metodologia desenvolvida foram avaliados por meio da validação do método seguindo as orientações do INMETRO e da Eurachem. E na terceira etapa, as amostras provenientes do rio Paraíba do Sul foram analisadas, possibilitando a identificação e a quantificação dos compostos presentes.

\subsection{REAGENTES, MATERIAIS E EQUiPAMENTOS}

Para o desenvolvimento deste estudo foram empregados os reagentes metanol $(\mathrm{MeOH})$, acetato de etila (EtOAc), diclorometano (DCM) e acetona, todos de grau cromatográfico, de procedência J.T.Baker. O equipamento Elix 3, da Millipore foi utilizado para purificação da água por osmose reversa. $E$ a água ultrapura de baixa condutância (tipo 1) foi obtida após purificação pelo equipamento EasyPure, da Barnstead.

Uma solução de ácido nítrico p.a. e ácido sulfúrico p.a. $\left(\mathrm{HNO}_{3} / \mathrm{H}_{2} \mathrm{SO}_{4}\right.$ $1: 1, v / v)$, de procedência Merk, foi utilizada para descontaminação das vidrarias. Para acidificação das amostras, foi usada uma solução de ácido clorídrico $50 \%$ $\left(\mathrm{HCl} / \mathrm{H}_{2} \mathrm{O} 1: 1, \mathrm{v} / \mathrm{v}\right)$, também de procedência Merk. Utilizou-se ainda o reagente tiossulfato de sódio anidro $\left(\mathrm{Na}_{2} \mathrm{~S}_{2} \mathrm{O}_{3}\right)$, da J.T.Baker para eliminação de cloro livre, e gás nitrogênio comprimido 4.6 e 5.0 analítico, da White Martins, para secagem dos extratos. 
Os padrões analíticos dos compostos foram adquiridos da SigmaAldrich Co. A identificação dos seis analitos, assim como a pureza dos reagentes e a nomenclatura adotada pela IUPAC (International Union of Pure and Applied Chemistry) pode ser observada na TAB. 5.

TABELA 5. Identificação dos seis padrões analíticos empregados no estudo.

\begin{tabular}{ccccc}
\hline Composto & $\begin{array}{c}\text { Número } \\
\text { CAS }\end{array}$ & $\begin{array}{c}\text { Fórmula } \\
\text { molecular }\end{array}$ & Pureza & Nome IUPAC \\
\hline Dietilftalato & $84-66-2$ & $\mathrm{C}_{12} \mathrm{H}_{14} \mathrm{O}_{4}$ & $99,7 \%$ & dietil benzeno-1,2-dicarboxilato \\
Dibutilftalato & $84-74-2$ & $\mathrm{C}_{16} \mathrm{H}_{22} \mathrm{O}_{4}$ & $98,7 \%$ & dibutil benzeno-1,2-dicarboxilato \\
Nonilfenol & $84852-15-3$ & $\mathrm{C}_{15} \mathrm{H}_{24} \mathrm{O}$ & $92,5 \%$ & 4-nonilfenol (ramificado) \\
Pentaclorofenol & $87-86-5$ & $\mathrm{C}_{6} \mathrm{HCl}_{5} \mathrm{O}$ & $99,6 \%$ & pentaclorofenol \\
Bisfenol $A$ & $80-05-7$ & $\mathrm{C}_{15} \mathrm{H}_{16} \mathrm{O}_{2}$ & $99,1 \%$ & 2,2-bis(4-hidroxifenill)propano \\
Benzo[a]pireno & $50-32-8$ & $\mathrm{C}_{20} \mathrm{H}_{12}$ & $99 \%$ & benzo[a]pireno \\
\hline
\end{tabular}

Além dos equipamentos e materiais já mencionados, para execução do método utilizou-se:

- Cromatógrafo a gás - GC17A, acoplado ao detector de espectrometria de massas - QP 5000, ambos da marca Shimadzu; um microprocessador de dados equipado com o programa GC/MS Solution;

- Sistema de filtração a vácuo, marca Sartórius;

- Compressor/aspirador (Dia pump), modelo 089 cal, marca FANEM;

- Sistema de extração em fase sólida desenvolvido nos laboratórios do CQMA (FIG. 14);

- Balança analítica, modelo H16, marca Mettler, com cinco casas decimais e precisão na quarta casa;

- Centrífuga microprocessada de bancada, marca Nova Técnica;

- Forno micro-ondas, modelo ME900, marca Eletrolux.

Para preparo das amostras foram utilizados os seguintes materiais de consumo: 
- Vidraria básica de laboratório;

- Cartuchos de extração em fase sólida (SPE), de $6 \mathrm{~mL}$ preenchidos com 500 mg de octadecil $\left(\mathrm{C}_{18}\right)$, Supelclean ${ }^{\mathrm{TM}} \mathrm{ENVI}^{\mathrm{TM}}{ }^{\text {; }}$

- Membranas de nitrocelulose, de 0,45 $\mu \mathrm{m}$, Sartorius;

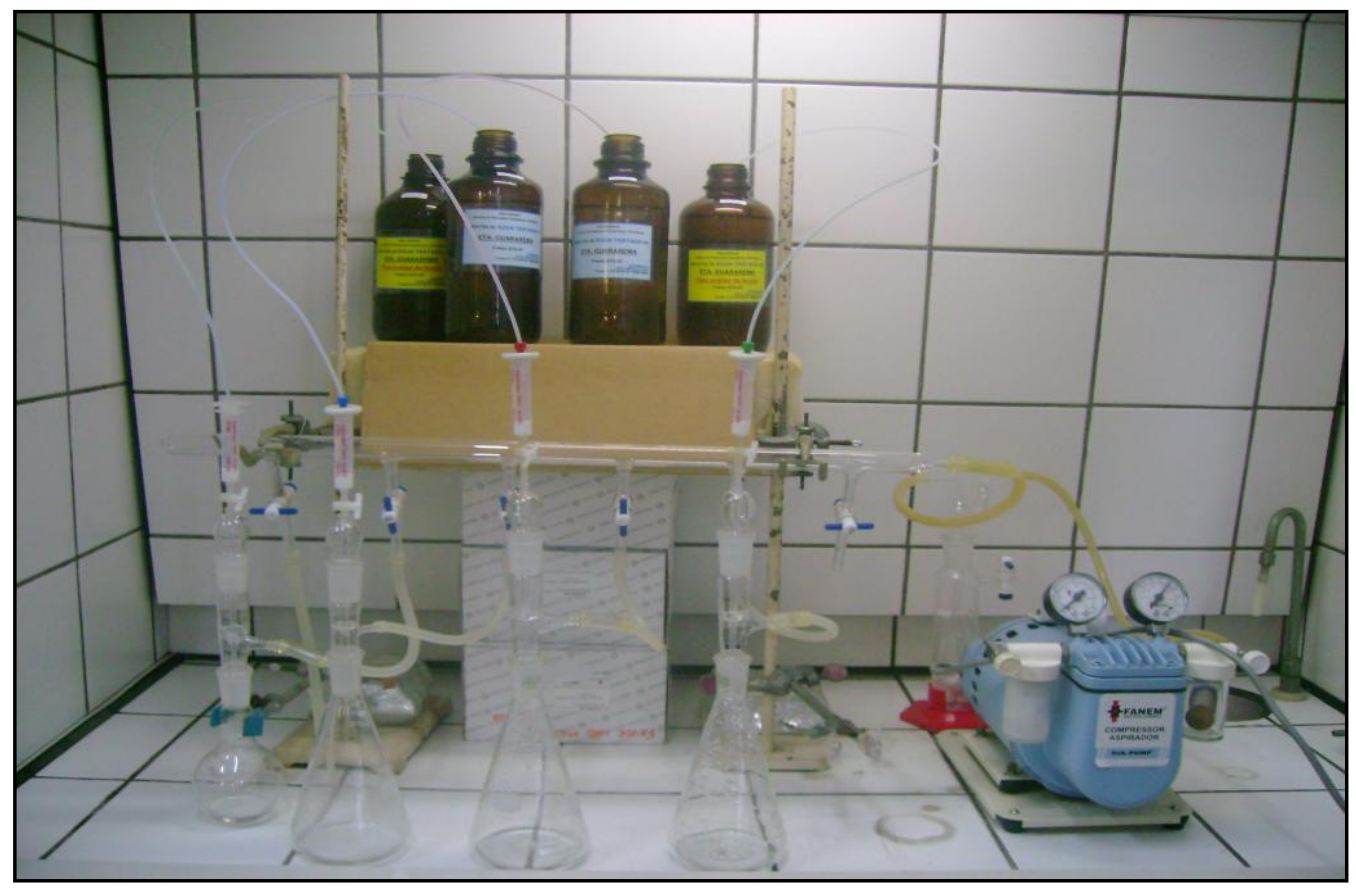

FIGURA 14. Sistema de extração em fase sólida utilizado para concentração dos analitos, e bomba a vácuo.

\subsection{CONSIDERAÇÕES SOBRE CONTAMINAÇÃO}

Uma das maiores dificuldades na análise de traços, em especial análise de plastificantes, é a contaminação das diversas matrizes por estes compostos, que se encontram disseminados no meio ambiente, além de serem encontrados em diversos materiais de laboratório. Com o intuito de evitar a contaminação, maior atenção foi dada a todo o processo, como por exemplo, evitando-se o uso e o contato com materiais plásticos.

Em relação à limpeza das vidrarias, após serem lavadas em água corrente e detergente, foram descontaminadas empregando-se a solução nitro sulfônica pelo período aproximado de 24h. Em seguida foram enxaguadas 10 
vezes com água tratada por osmose reversa e 10 vezes com água ultrapura (tipo 1). As vidrarias não volumétricas foram secas em forno microondas, e as que não poderiam ser aquecidas foram secas em temperatura ambiente, sempre protegidas. Papel alumínio foi utilizado para embalar as vidrarias limpas antes de serem armazenadas.

Ainda visando avaliar uma possível presença desses compostos, paralelamente ao procedimento de extração, na etapa de definição do método, validação ou análise das amostras, foram realizadas análises de brancos do equipamento por meio da injeção de solventes (EtOAc/MeOH) e brancos do processo de extração. Os resultados dos brancos são reportados no item 6.3 do capítulo 6.

\subsection{Metodologia analítica}

\subsubsection{Estudos preliminares para extração dos DEs}

Como não há uma metodologia padronizada para a análise dos disruptores endócrinos abordados por este estudo, inicialmente foi feito um levantamento bibliográfico dos métodos de extração utilizados. Poucos são os trabalhos que empregam a extração liquído-líquido para concentração dos analitos (Zafra et al., 2003; Jin et al., 2004). A extração empregando cartuchos de SPE é a técnica mais usual.

Dessa forma, inicialmente, foram selecionadas cinco metodologias para realização dos testes de extração (TAB. 6). Nesta primeira etapa, os testes qualitativos foram realizados utilizando dois tipos de cartuchos SPE, OASIS ${ }^{\circledR} H L B$ Cartridge da Waters (500 mg, $1 \mathrm{~mL})$ e Supelclean ${ }^{T M} E N V I^{T M}-\mathrm{C}_{18}(500 \mathrm{mg}, 6 \mathrm{~mL})$. A extração foi feita percolando-se $1 \mathrm{~L}$ de água de osmose reversa fortificada com a solução mix dos padrões. 
TABELA 6. Testes de extração preliminares para definição da metodologia.

\begin{tabular}{|c|c|c|c|c|c|}
\hline Teste & Cartucho & Condicionamento & $\mathrm{pH}$ & Eluição & Referência \\
\hline 1 & $\mathrm{ENVI}^{\mathrm{TM}}-\mathrm{C}_{18}$ & $\begin{array}{c}5 \mathrm{~mL} \mathrm{MeOH}+ \\
5 \mathrm{~mL} \mathrm{MeOH} / \mathrm{H}_{2} \mathrm{O} \\
(10: 90)\end{array}$ & 3 & $\begin{array}{c}5 \mathrm{~mL} \\
\mathrm{DCM} / \mathrm{MeOH} \\
(60: 40)\end{array}$ & $\begin{array}{l}\text { Otomo } \\
(2010)\end{array}$ \\
\hline 2 & $\begin{array}{l}\text { OASIS }^{\circledR} \\
\text { HLB }\end{array}$ & $\begin{array}{c}5 \mathrm{~mL} \mathrm{MeOH}+ \\
5 \mathrm{~mL} \mathrm{MeOH} / \mathrm{H}_{2} \mathrm{O} \\
(10: 90)\end{array}$ & 3 & $\begin{array}{c}5 \mathrm{~mL} \\
\mathrm{DCM} / \mathrm{MeOH} \\
(60: 40) \\
\end{array}$ & $\begin{array}{c}\text { Adaptado de } \\
\text { Otomo } \\
(2010) \\
\end{array}$ \\
\hline 3 & $E N V I^{\mathrm{TM}}-\mathrm{C}_{18}$ & $\begin{array}{c}5 \mathrm{~mL} \mathrm{EtOAc}+ \\
5 \mathrm{~mL} \mathrm{MeOH}+ \\
5 \mathrm{~mL} \mathrm{H}_{2} \mathrm{O}\end{array}$ & 3 & $\begin{array}{c}2 \times 3 \mathrm{~mL} \\
\text { EtOAc/MeOH } \\
(60: 40)\end{array}$ & $\begin{array}{c}\text { Adaptado de } \\
\text { Moreira } \\
(2008)\end{array}$ \\
\hline 4 & $\mathrm{ENVI}^{\mathrm{TM}}-\mathrm{C}_{18}$ & $\begin{array}{c}5 \mathrm{ml} \text { EtOAc + } \\
5 \mathrm{ml} \mathrm{MeOH} / \mathrm{H}_{2} \mathrm{O}(1: 1)\end{array}$ & neutro & $\begin{array}{c}2 \times 4 \mathrm{~mL} \\
\mathrm{EtOAc}\end{array}$ & $\begin{array}{c}\text { Adaptado de } \\
\text { Hernando } \\
(2004)\end{array}$ \\
\hline 5 & $E N V I^{\mathrm{TM}}-\mathrm{C}_{18}$ & $\begin{array}{c}5 \mathrm{ml} \text { EtOAc + } \\
6 \mathrm{ml} \mathrm{MeOH} / \mathrm{H}_{2} \mathrm{O}(1: 1)\end{array}$ & 3 & $\begin{array}{c}2 \times 4 \mathrm{~mL} \\
\mathrm{EtOAc}\end{array}$ & $\begin{array}{l}\text { Adaptado de } \\
\text { Mol (2000) }\end{array}$ \\
\hline
\end{tabular}

Após definição das melhores condições de extração dos compostos pelos testes qualitativos, foi realizada uma segunda bateria de ensaios quantitativos. Nesta etapa, os testes 1 e 3 foram selecionados por apresentarem os melhores resultados, portanto, todos os testes foram feitos com o cartucho Supelclean ${ }^{T M} E N V I^{T M}-\mathrm{C}_{18}$. Utilizou-se $0,5 \mathrm{~L}$ das amostras de água tratada para avaliação dos efeitos da matriz sobre a extração. Apenas as condições de $\mathrm{pH} \mathrm{e}$ clean up das extrações foram variadas conforme TAB. 7.

TABELA 7. Testes de extração para definição do método de extração.

\begin{tabular}{|c|c|c|c|c|c|}
\hline Teste & Cartucho & Condicionamento & $\mathrm{pH}$ & Lavagem & Eluição \\
\hline 6 & $E N V^{T M}-C_{18}$ & $\begin{array}{c}5 \mathrm{~mL} \mathrm{MeOH}+ \\
5 \mathrm{~mL} \mathrm{MeOH} / \mathrm{H}_{2} \mathrm{O} \\
(10: 90)\end{array}$ & 3 & - & $\begin{array}{c}5 \mathrm{~mL} \text { de } \\
\mathrm{DCM} / \mathrm{MeOH} \\
(60: 40)\end{array}$ \\
\hline 7 & $E N V I^{T M}-C_{18}$ & $\begin{array}{c}5 \mathrm{~mL} \mathrm{MeOH}+ \\
5 \mathrm{~mL} \mathrm{MeOH} / \mathrm{H}_{2} \mathrm{O} \\
(10: 90)\end{array}$ & 7 & $\begin{array}{c}5 \mathrm{~mL} \text { de } \\
\mathrm{MeOH} / \mathrm{H} 2 \mathrm{O} \\
(10: 90)\end{array}$ & $\begin{array}{c}5 \mathrm{~mL} \text { de } \\
\mathrm{DCM} / \mathrm{MeOH} \\
(60: 40)\end{array}$ \\
\hline 8 & $E N V I^{T M}-C_{18}$ & $\begin{array}{c}5 \mathrm{~mL} \text { EtOAc }+ \\
5 \mathrm{~mL} \mathrm{MeOH} / \mathrm{H}_{2} \mathrm{O} \\
(1: 1)\end{array}$ & 7 & $\begin{array}{c}5 \mathrm{~mL} \\
\mathrm{MeOH} / \mathrm{H} 2 \mathrm{O} \\
(10: 90)\end{array}$ & $\begin{array}{c}2 \times 3 \mathrm{~mL} \text { de } \\
\text { EtOAc/MeOH } \\
(60: 40)\end{array}$ \\
\hline 9 & $E N V^{T M}-C_{18}$ & $\begin{array}{c}5 \mathrm{~mL} \text { EtOAc }+ \\
5 \mathrm{~mL} \mathrm{MeOH} / \mathrm{H}_{2} \mathrm{O} \\
(1: 1)\end{array}$ & 3 & - & $\begin{array}{c}2 \times 3 \mathrm{~mL} \text { de } \\
\mathrm{EtOAc} / \mathrm{MeOH} \\
(60: 40)\end{array}$ \\
\hline
\end{tabular}


...continuação TABELA 7.

\begin{tabular}{|c|c|c|c|c|c|}
\hline 10 & $\mathrm{ENVI}^{\mathrm{TM}}-\mathrm{C}_{18}$ & $\begin{array}{c}5 \mathrm{~mL} \text { EtOAc }+ \\
5 \mathrm{~mL} \mathrm{MeOH} / \mathrm{H}_{2} \mathrm{O} \\
(1: 1)\end{array}$ & 3 & $\begin{array}{c}5 \mathrm{~mL} \\
\mathrm{MeOH} / \mathrm{H} 2 \mathrm{O} \\
(10: 90)\end{array}$ & $\begin{array}{c}2 \times 3 \mathrm{~mL} d e \\
\text { EtOAc/MeOH } \\
(60: 40)\end{array}$ \\
\hline 11 & $\mathrm{ENVI}^{\mathrm{TM}}-\mathrm{C}_{18}$ & $\begin{array}{c}5 \mathrm{~mL} \text { EtOAc }+ \\
5 \mathrm{~mL} \mathrm{MeOH} / \mathrm{H}_{2} \mathrm{O} \\
(1: 1)\end{array}$ & neutro & $\begin{array}{c}5 \mathrm{~mL} \\
\mathrm{MeOH} / \mathrm{H} 2 \mathrm{O} \\
(10: 90)\end{array}$ & $\begin{array}{c}2 \times 3 \mathrm{~mL} d e \\
\mathrm{EtOAc} / \mathrm{MeOH} \\
(60: 40)\end{array}$ \\
\hline
\end{tabular}

Os resultados que levaram à definição do método de extração por SPE são discutidos no item 6.1 do capítulo 6 .

\subsubsection{Método final pela técnica SPE}

No fluxograma da FIG. 15 são apresentadas as etapas para a extração e análise dos xenoestrógenos nas amostras ambientais. A metodologia final baseou-se no método proposto por Moreira (2008). Todavia, outros autores descrevem métodos semelhantes nesta etapa analítica (Mol, 2000; Hernando, 2004).

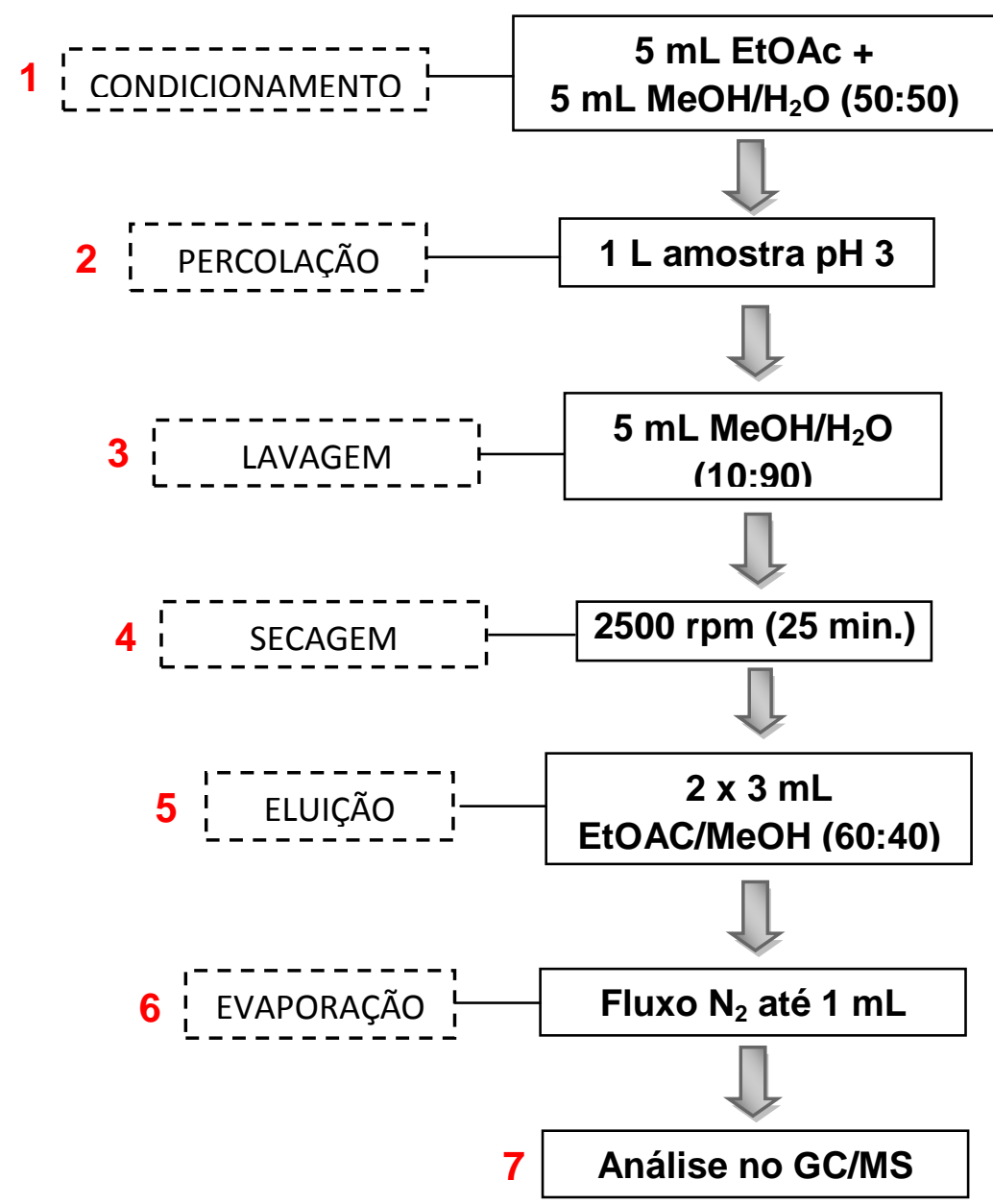

FIGURA 15. Fluxograma das etapas para extração e análise dos analitos por SPEGC/MS. 
1. Condicionamento: $\mathrm{O}$ cartucho de SPE $\mathrm{C}_{18}$ é condicionado com $5 \mathrm{~mL}$ de acetato de etila, seguido de $5 \mathrm{~mL}$ de metanol/ $\mathrm{H}_{2} \mathrm{O}$ ultrapura $(50: 50, \mathrm{v} / \mathrm{v})$, inicialmente por gravidade e depois a um fluxo de 1-2 mL. $\mathrm{min}^{-1}$. Ficando cada solução em contato com o material adsorvente para ativá-lo por cerca de 2 minutos.

2. Percolação da amostra: 0 volume de $1 \mathrm{~L}$ da amostra, que foi previamente filtrado a vácuo utilizando membranas $0,45 \mu \mathrm{m}$ e acidificada para $\mathrm{pH} 3 \mathrm{com}$ solução de ácido clorídrico, é percolada pelo cartucho a um fluxo de 5-6 mL. $\mathrm{min}^{-1}$;

3. Lavagem: sem deixar o cartucho secar, a etapa de clean up, para remoção de interferentes, é realizada com $5 \mathrm{~mL}$ de metanol $/ \mathrm{H}_{2} \mathrm{O}$ ultrapura $(10: 90, \mathrm{v} / \mathrm{v})$, também deixando a solução em contato por 2 minutos;

4. Secagem: para remoção completa da água, o cartucho é seco primeiramente por 10 minutos sob vácuo, em seguida é transferido para tubos de centrífuga, onde é centrifugado por 25 minutos, a uma rotação de 2.500 r.p.m. (rotações por minuto);

5. Eluição: a dessorção dos analitos é feita com $2 \times 3 \mathrm{~mL}$ de acetato de etila/metanol (60:40, v/v), a um fluxo de 1-2 $\mathrm{mL} \cdot \mathrm{min}^{-1}$, sendo o extrato recolhido em tubos de ensaio. Cada alíquota dos solventes é deixada em contato com o material de empacotamento do cartucho por 2 minutos.

6. Evaporação: com auxílio de uma pipeta automática, o extrato é transferido para balões volumétricos de $1 \mathrm{~mL}$, onde é concentrado sob fluxo suave de $\mathrm{N}_{2}$. Ao final da transferência, as paredes do tubo de ensaio são lavadas com aproximadamente $200 \mu \mathrm{L}$ da solução de EtOAc/MeOH, 60:40 para evitar a perda dos analitos;

7. Análise por GC/MS: o extrato é avolumado para $1 \mathrm{~mL}$ com a própria solução de eluição (EtOAc/MeOH, 60:40), e segue para a análise no cromatógrafo. Quando não foi possível realizar a análise cromatográfica no mesmo dia, o extrato, antes de ser avolumado, foi armazenado sob refrigeração pelo período máximo de 24 horas. 


\subsubsection{Condições cromatográficas}

Para se obter as melhores condições de análise dos disruptores endócrinos por cromatografia gasosa acoplada à espectrometria de massas (GC/MS), inicialmente foram realizadas injeções dos padrões individuais para a obtenção do tempo de retenção das substâncias e para a avaliação da sensibilidade do detector. Posteriormente, injeções de uma solução com todos os padrões (solução mix) foram realizadas variando-se o fluxo do gás de arraste, programação do forno, temperaturas do injetor e interface, e voltagem do detector.

Para a separação dos analitos, foi empregada a coluna capilar DB-5 (30 m x 0,25 mm d.i. x 0,25 $\mu \mathrm{m}$ da fase dimetilpolisiloxano). Após avaliação das melhores condições, as temperaturas do injetor e da interface GC/MS foram estabelecidas em $270^{\circ} \mathrm{C}$ e $290^{\circ} \mathrm{C}$, respectivamente. A programação da temperatura (FIG. 16) do forno teve inicio em $80^{\circ} \mathrm{C}$ e foi finalizada em $280^{\circ} \mathrm{C}$, com isotermas em $210^{\circ} \mathrm{C}$ e $280^{\circ} \mathrm{C}$. O tempo total da corrida cromatográfica foi de 24,35 minutos.

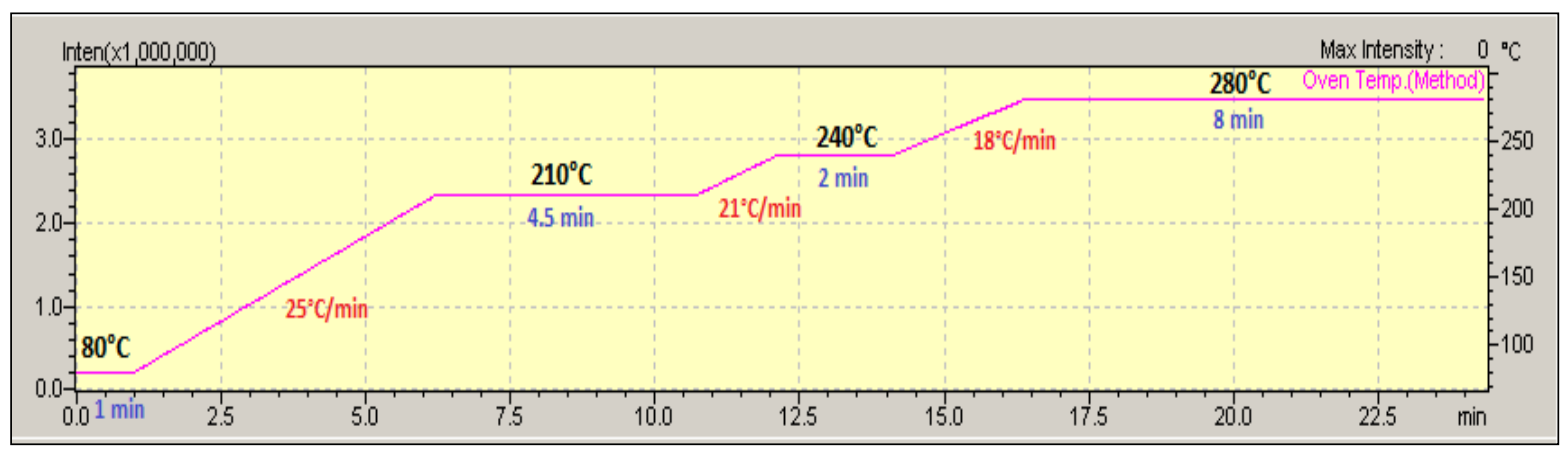

FIGURA 16. Programação da temperatura definida no GC/MS.

O volume de $1 \mu \mathrm{L}$ do extrato foi injetado manualmente no modo splitless, com fluxo de 1,6 mL. $\mathrm{min}^{-1}$ na coluna, e fluxo total de $28 \mathrm{~mL} \cdot \mathrm{min}^{-1}$, utilizando-se hélio como gás de arraste. A energia de ionização dos fragmentos foi de $70 \mathrm{eV}$. O modo de aquisição SCAN foi utilizado nas análises qualitativas, sendo o intervalo de varredura entre 70 e $350 \mathrm{~m} / \mathrm{z}$. O modo SIM (select ion monitoring) foi aplicado nas análises quantitativas. 


\subsubsection{Quantificação das amostras por GC/MS}

Como mencionado anteriormente, as análises quantitativas foram realizadas no modo SIM por meio de injeções em triplicata. Os tempos de retenção (TR) e os espectros de massas de cada composto foram conhecidos pelas injeções da mistura dos padrões analíticos. A seleção dos íons monitorados foi realizada com base na literatura e nos próprios espectros de massas. As relações massa/carga $(\mathrm{m} / \mathrm{z})$ características dos analitos, assim como o intervalo de monitoramento dos fragmentos e os tempos de retenção encontram-se na TAB. 8.

TABELA 8. Intervalo de monitoramento, tempos de retenção (TR) e relação massa/carga dos íons de cada composto monitorado no modo SIM.

\begin{tabular}{cccc}
\hline Composto & $\begin{array}{c}\text { Intervalo de tempo } \\
(\mathbf{m i n} .)\end{array}$ & TR (min.) & Íons monitorados $(\mathbf{m} / \mathbf{z})$ \\
\hline Dietilftalato & $5,00-7,10$ & 6,71 & $149^{*}, 176,177,221,222$ \\
Nonilfenol & $7,10-8,05$ & $7,08-$ & $107^{*}, 121,135,149,220$ \\
Pentaclorofenol & $8,05-8,70$ & 8,90 & \\
Dibutilftalato & $8,70-11,00$ & 9,83 & $149^{*}, 150,223,278,279$ \\
Bisfenol A & $11,00-16,00$ & 12,56 & $119,213^{*}, 214,228,229$ \\
Benzo[a]pireno & $16,00-24,00$ & 20,20 & $113,126,250,251,252^{*}$ \\
\hline
\end{tabular}

* Íons de maior intensidade

Como não há uma matriz de referência ou padrão interno adequado para os compostos estudados, para a quantificação dos analitos foi utilizado o método de superposição de matriz e padronização externa, onde as concentrações crescentes da solução mix dos padrões foram adicionadas às matrizes de água bruta e água tratada para confecção das curvas analíticas.

Para preparação dos padrões analíticos pesou-se individualmente $1 \mathrm{mg}$ dos compostos bisfenol A (BPA), pentaclorofenol (PCP) e benzo[a]pireno $(\mathrm{B}[\mathrm{a}] \mathrm{P})$ em balão volumétrico de $10 \mathrm{~mL}$ e diluiu-os em metanol, obtendo-se uma solução estoque de $100 \mu \mathrm{g} \cdot \mathrm{mL}^{-1}$. As soluções estoque dos padrões líquidos de dietilftlato (DEP), dibutilftalato (DBP) e nonilfenol (NP) foram preparadas em balão 
de $50 \mathrm{~mL}$ e diluídas em metanol. A partir desta solução estoque foi preparada uma solução intermediária também em metanol, com concentração de 1.000 $\mu \mathrm{g} \cdot \mathrm{mL}^{-1}$ do nonilfenol e de $500 \mu \mathrm{g} \cdot \mathrm{mL}^{-1}$ dos ftalatos.

A solução mix dos padrões estudados foi preparada em metanol a partir dos estoques individuais. As diluições das soluções de trabalho foram preparadas com a solução dos solventes $\mathrm{EtOAc/MeOH}(60: 40$, v/v) por ser a solução de eluição e por haver diferença na resposta do detector em relação às injeções somente em metanol. Todas as soluções foram armazenadas ao abrigo de luz e sob refrigeração. Pela sensibilidade do detector ser distinta para cada composto, as concentrações de trabalho utilizadas para confecção das curvas analíticas e para os ensaios de validação foram de ordem de grandeza diferentes, como pode ser visto na TAB. 9.

TABELA 9. Concentrações das soluções de trabalhos dos seis compostos estudados.

\begin{tabular}{|c|c|c|c|c|c|c|}
\hline & DEP & DBP & NP & PCP & BPA & $\mathrm{B}[\mathrm{a}] \mathrm{P}$ \\
\hline \multirow{8}{*}{ 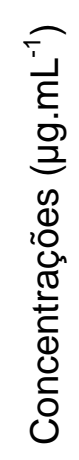 } & 0,025 & 0,025 & 0,050 & 0,100 & 0,100 & 0,100 \\
\hline & 0,050 & 0,050 & 0,100 & 0,200 & 0,200 & 0,200 \\
\hline & 0,100 & 0,100 & 0,200 & 0,400 & 0,400 & 0,400 \\
\hline & 0,200 & 0,200 & 0,400 & 0,800 & 0,800 & 0,800 \\
\hline & 0,350 & 0,350 & 0,700 & 1,400 & 1,400 & 1,400 \\
\hline & 0,550 & 0,550 & 1,100 & 2,200 & 2,200 & 2,200 \\
\hline & 0,750 & 0,750 & 1,500 & 3,000 & 3,000 & 3,000 \\
\hline & 1,000 & 1,000 & 2,000 & 4,000 & 4,000 & 4,000 \\
\hline
\end{tabular}

\subsection{AVALIAÇÃo dos PaRÂmetros de deSEMPENHO ANALÍtico}

Após definição das melhores condições de extração e análise dos compostos, foram realizados os ensaios para validação da metodologia. Da mesma maneira que na obtenção das curvas analíticas, por não haver uma matriz de referência, para avaliação da seletividade, especificidade, faixa de trabalho e linearidade, limites de detecção e quantificação, precisão e exatidão, também foi utilizada uma matriz semelhante à amostra. Mais especificamente, foram realizados ensaios nas próprias amostras de água tratada e bruta. 
Para realização dos ensaios nas matrizes, foram feitas quatro extrações, conforme procedimento descrito no item 5.3.2, com amostras de água bruta ou água tratada provenientes da cidade de Guararema por ser a amostra que apresentou menor contaminação pelos poluentes e ser a mais rica em ácidos orgânicos que poderiam comprometer o desempenho do método. O eluato de cada extração foi recolhido em conjunto, totalizando $24 \mathrm{~mL}$, este volume foi dividido em nove alíquotas de aproximadamente 2,5 mL. Em oito alíquotas foram adicionados volumes conhecidos da solução padrão mix, compondo os oito níveis de concentrações apresentados na TAB. 9. A alíquota sem adição de padrão foi utilizada como branco da matriz.

Além dos ensaios realizados nas duas matrizes (água bruta e tratada), foi também preparado um conjunto de soluções com as mesmas oito concentrações (TAB. 9) sem a matriz, isto é, somente na solução de solvente EtOAc/MeOH (60:40, v/v). As injeções de cada nível de concentração nos ensaios com e sem matriz foram realizadas com sete replicatas para obtenção das áreas dos picos cromatográficos.

Como mencionado, para análise dos resultados e aplicação dos cálculos estatísticos foi utilizada e planilha "Validação de Ensaios Químicos" desenvolvida por Furusawa (2007), e que é baseada nas orientações do INMETRO (2003, 2007, 2010).

\subsubsection{Determinação da seletividade}

A seletividade da metodologia foi avaliada inicialmente por comparação visual dos cromatogramas obtidos pelas injeções das oito soluções padrão com e sem matriz, observando-se a separação dos seis compostos estudados e também o comportamento das curvas analíticas pela sobreposição das retas.

Posteriormente, foram aplicados cálculos estatísticos a partir das áreas das replicatas. Os testes estatísticos utilizados foram: teste F (Snedecor) de homogeneidade das variâncias, teste t (Student) de significância da diferenças 
das médias, teste de inclinação e paralelismo e teste do intercepto, também pelo t Student.

Para o cálculo do teste $F$ utilizou-se a variância das áreas das replicatas dos dois grupos de soluções contendo os padrões de acordo com a equação 4. Os valores obtidos são denominados de $F_{\text {calculado }}$ e são comparados a

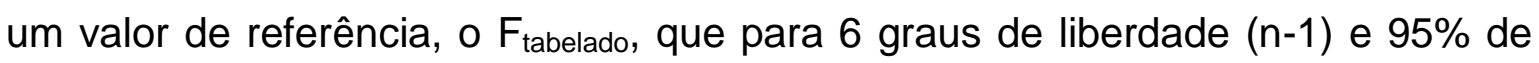
confiança é igual a 4,28.

$$
F=\frac{s_{1}^{2}}{s_{2}^{2}}
$$

onde:

$s_{1}^{2}=$ maior variância (ensaios com a matriz);

$s_{2}^{2}=$ menor variância (ensaios sem a matriz).

Caso o teste $F$ seja significante, ou seja, os valores de $F_{\text {calculado sejam }}$

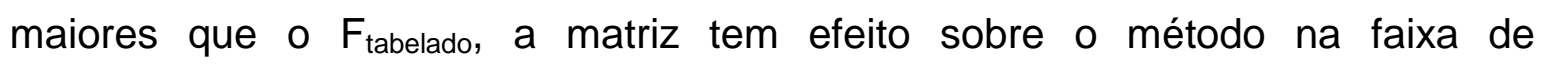
concentração considerada, então o teste $\mathrm{t}$ Student de comparação das médias deve ser efetuado pela equações 5 .

$$
t_{\text {calculado }}=\frac{\left|\overline{x_{1}}-\overline{x_{2}}\right|}{\sqrt{\frac{s_{1}^{2}}{n_{1}}+\frac{s_{2}^{2}}{n_{2}}}}
$$

Para o cálculo do número de graus de liberdade deve-se seguir a equação 6. 


$$
v=\frac{\left(\frac{s_{1}^{2}}{n_{1}}+\frac{s_{2}^{2}}{n_{2}}\right)^{2}}{\frac{\left(\frac{s_{1}^{2}}{n_{1}}\right)^{2}}{n_{1}+1}+\frac{\left(\frac{s_{2}^{2}}{n_{2}}\right)^{2}}{n_{2}+1}}-2
$$

Nas equações 5 e 6 considera-se:

$\overline{\mathrm{X}}_{1}$ e $\overline{\mathrm{X}}_{2}=$ média das replicatas nas soluções com e sem a matriz, no mesmo nível de concentração;

$S_{1}^{2}$ e $S_{2}^{2}=$ variância das replicatas nas soluções com e sem a matriz, respectivamente;

$n_{1}$ e $n_{2}=$ tamanho do conjunto de soluções com e sem a matriz, respectivamente.

Da mesma forma que no teste $F$, no teste $t o$ valor de $t_{\text {calculado }}$ é comparado ao valor crítico $t_{12,95 \%}=2,179$, onde para valores de $t_{\text {cal }}>t_{\text {tab }}$ há diferença na média dos dois conjuntos de soluções e a matriz interfere estatisticamente sobre o resultado do método.

Ainda pela aplicação do teste t Student foi avaliada a inclinação e o paralelismo, e o intercepto das retas com e sem as matrizes. $O$ teste de inclinação e paralelismo foi calculado de acordo com a equação 7 , e o teste de intercepto seguiu a equação 8 .

$$
t=\frac{b_{1}-b_{2}}{\bar{S}_{x y} \sqrt{\frac{1}{\sum\left(x_{1 i}-\bar{x}\right)^{2}}+\frac{1}{\sum\left(x_{2 i}-\bar{x}\right)^{2}}}}
$$

onde:

$b_{1}=$ coeficiente linear da equação da reta do ensaio com matriz;

$b_{2}=$ coeficiente linear da equação da rela do ensaio sem matriz; 


$$
t=\frac{a_{1}-a_{2}}{\bar{S}_{x y} \sqrt{\frac{1}{n 1}+\frac{\bar{x}_{1}^{2}}{\sum\left(x_{1 i}-\bar{x}_{1}\right)^{2}}+\frac{1}{n 2}+\frac{\bar{x}_{2}^{2}}{\sum\left(x_{2 i}-\bar{x}_{2}\right)^{2}}}}
$$

onde:

$a_{1}=$ coeficiente angular da equação da reta do ensaio com matriz;

$a_{2}=$ coeficiente angular da equação da rela do ensaio sem matriz.

Os valores de $\bar{S}_{x y}$ das equações 7 e 8 devem ser calculado pela equação 9.

$$
\bar{S}_{x y}=\sqrt{\frac{\left(n_{1}-2\right) S_{y 1 x 1}^{2}+\left(n_{2}-2\right) S_{y 2 x 2}^{2}}{n_{1}+n_{2}-4}}
$$

onde:

$s^{2}=$ variância do conjunto de soluções com e sem matriz;

$n_{1}$ e $n_{2}=$ tamanhos do conjunto de amostras com e sem matriz.

\subsubsection{Determinação da linearidade e da faixa linear de trabalho}

Para composição da faixa de trabalho foram consideradas as oito concentrações demonstradas na TAB. 9, em seguida foram obtidas as retas de cada conjunto de soluções (matrizes água bruta e tratada e sem matriz) seguindo a equação 1 do item 3.8.2 e avaliou-se o coeficiente de determinação $\left(r^{2}\right)$.

A análise dos resíduos pelo teste t Student e pelos gráficos dos resíduos também foi realizada para avaliação da linearidade. Pelo teste dos resíduos é possível verificar se o ponto considerado desvia da linearidade da reta, e é calculado pela equação 10 . 


$$
t_{\text {calculado }}=\frac{\text { resíduo }}{\left(\frac{s_{r}}{\sqrt{n}}\right)}
$$

onde:

resíduo $=\left|x_{\text {medido }}-x_{\text {calculado }}\right|$

$\mathrm{s}_{\mathrm{r}}=$ desvio padrão dos resíduos

$\mathrm{n}$ = tamanho da amostra (número de pontos)

$O$ valor de $t_{\text {calculado }}$ é comparado ao valor de $t_{\text {tabelado. Nesta dissertação, }}$ considerou-se 7 graus de liberdade (n-1) e 95\% de confiança, portanto, o valor de t unilateral comparado ao $\mathrm{t}_{\text {calculado }}$ é igual a 2,365.

Foram considerados também os gráficos de distribuição espacial dos resíduos absolutos pela concentração e pela probabilidade normalizada de cada resíduo para avaliação de valores discrepantes (outliers). Ainda para avaliação da linearidade foram considerados os testes $F$ de regressão e de ajuste pelos cálculos da tabela ANOVA.

\subsubsection{Determinação do limite de detecção}

O limite de detecção (LD) do método foi calculado para cada matriz e somente da solução de solventes considerando-se o desvio padrão das sete replicatas da menor concentração dos analitos e a equação 11.

$$
L D=t_{(n-1, n-\alpha)} \cdot(s)
$$

onde:

$t_{(n-1, n-\alpha)}=$ valor de $t$ Student considerando $95 \%$ de confiança e $6(n-1)$ graus de liberdade

$\mathrm{S}=$ desvio padrão das replicatas 


\subsubsection{Determinação do limite de quantificação}

Os limites de quantificação (LQ) nas amostras de água tratada e água bruta foram calculados pela média dos brancos das matrizes mais cinco vezes o desvio padrão dessas determinações, conforme a equação 12.

Assim como na solução de solventes, quando o branco da matriz não apresentou valor de área suficiente para aplicação do cálculo, foram consideradas as médias da menor concentração do analito.

$$
L Q=\bar{X}+5 s
$$

onde:

$\overline{\mathrm{X}}=$ média das replicatas do branco da matriz ou da concentração do menor ponto da curva analítica;

$\mathrm{s}=$ desvio padrão das mesmas replicatas.

\subsubsection{Determinação da precisão}

A precisão do método foi avaliada por meio da repetitividade e da reprodutibilidade, para tanto foram consideradas as áreas das sete replicatas de diferentes concentrações, pelo mesmo analista, procedimento e equipamento, no mesmo dia ou em dias distintos.

Para o cálculo dos limites de repetitividade e reprodutibilidade foram utilizadas as equações 13 e 14, respectivamente.

$$
\begin{aligned}
& r=2,8 \cdot S_{r} \\
& R=2,8 \cdot \sqrt{S_{R}^{2}}
\end{aligned}
$$

onde:

$\mathrm{S}_{\mathrm{r}}=$ desvio padrão das replicatas utilizadas no ensaio da repetitividade;

$S_{R}^{2}=$ variância das replicatas utilizadas no ensaio de reprodutibilidade. 
A precisão foi determinada também pelo desvio padrão relativo (DPR) das medições, conforme a equação 2 do item 3.8.4.

\subsubsection{Determinação da exatidão}

Neste trabalho, a exatidão da metodologia foi avaliada utilizando-se a tabela ANOVA, materiais de referência certificados (ensaios de recuperação), e aplicação do índice z Score a partir dos resultados obtidos.

O teste z Score foi calculado pela equação 15. Para valores de $|z|<2$ o resultado é satisfatório, caso o $|z|$ esteja entre 2 e 3 , o resultado é questionável, e para $|z|>3$, o resultado é insatisfatório.

$$
Z=\frac{\left(X_{l a b}-X_{v}\right)}{s}
$$

onde:

$\mathrm{X}_{\mathrm{lab}}=$ valor obtido experimentalmente ou média dos valores;

$\mathrm{X}_{\mathrm{v}}=$ valor aceito como verdadeiro (valor certificado do $\mathrm{MRC}$ ).

\subsubsection{Estudo de Recuperação}

Para avaliação da recuperação do método, assim como em todo ensaio de validação, foram utilizadas amostras de água tratada e bruta coletadas no município de Guararema.

No ensaio, $500 \mathrm{~mL}$ de amostra foram fortificadas com volumes conhecidos da solução mix dos seis padrões analíticos em três níveis de concentração, conforme TAB. 10, e em seguida extraídas pelo procedimento descrito no item 5.3.2. 
TABELA 10. Concentrações dos três níveis de fortificações ensaiadas para o estudo de recuperação.

\begin{tabular}{ccccccc}
\hline \multirow{2}{*}{$\begin{array}{c}\text { Concentração } \\
\left(\mu \mathrm{g} \cdot \mathrm{L}^{-1}\right)\end{array}$} & DEP & DBP & NP & PCP & BPA & B[a]P \\
\cline { 2 - 7 } baixa & 0,075 & 0,075 & 0,150 & 0,315 & 0,300 & 0,300 \\
média & 0,400 & 0,400 & 0,800 & 1,680 & 1,600 & 1,600 \\
alta & 1,000 & 1,000 & 2,00 & 4,200 & 4,000 & 4,000 \\
\hline
\end{tabular}

\subsubsection{Ensaios de robustez}

A robustez do método foi avaliada utilizando-se os cálculos da planilha elaborada por Furusawa (2007), que segue a metodologia proposta por Vander Heyden et al. (2001), onde a robustez é avaliada pelo planejamento fatorial de 7 variáveis combinadas em 8 experimentos distintos (planejamento fracionário saturado).

Na TAB. 11 são apresentados os parâmetros selecionados para o ensaio de robustez. Os ensaios foram realizados nas duas matrizes, onde as mesmas foram fortificadas com a adição de concentrações conhecidas da solução mix dos seis padrões analíticos. Os 8 experimentos (para cada matriz) foram executados seguindo-se as combinações resultantes da tabela de "combinações ensaiadas" do INMETRO (2003) e que é demonstrada na TAB. 3 do item 3.8.7.

TABELA 11. Parâmetros nominais e suas variações selecionadas para o ensaio de robustez.

\begin{tabular}{c|cc}
\hline Parâmetro & Nominal & Variação \\
\hline pH da amostra & 3 & original \\
Proporção da mistura extratora & $60 \mathrm{EtOAc} \mathrm{:} \mathrm{40} \mathrm{MeOH}$ & $40 \mathrm{EtOAc} \mathrm{:} \mathrm{60} \mathrm{MeOH}$ \\
Volume solvente para eluição & $2 \times 3 \mathrm{~mL}$ & $4 \mathrm{~mL}$ \\
Temperatura do injetor & $270^{\circ} \mathrm{C}$ & $280^{\circ} \mathrm{C}$ \\
Temperatura da interface & $290^{\circ} \mathrm{C}$ & $280^{\circ} \mathrm{C}$ \\
Fluxo da coluna & $1,6 \mathrm{~mL} / \mathrm{min}$ & $1,8 \mathrm{~mL} / \mathrm{min}$ \\
Voltagem do detector & $2,5 \mathrm{kV}$ & $2,3 \mathrm{kV}$ \\
\hline
\end{tabular}




\subsubsection{Cálculos das incertezas}

Como demonstrado no diagrama de Causa e Efeito da FIG. 10 do item 3.8.8.1, as três principais fontes de incerteza identificadas na análise dos xenoestrógenos nas amostras de água foram as associadas à curva analítica, ao fator de recuperação e ao volume final do extrato.

As incertezas combinadas foram calculadas a partir das incertezas individuais das grandezas de entrada para cada uma das fontes identificadas. Para combinar as diferentes unidades de medida, foram calculados os coeficientes de sensibilidade, ci, fatores de conversão de unidades de medida, os quais são utilizados para converter a incerteza padrão de cada variável, u(xi), para a mesma unidade de medida de Y. O produto entre a incerteza padrão, u(xi), e seu respectivo coeficiente de sensibilidade, ci, dá origem a contribuição de incerteza, ui(y), que corresponde a uma medida de dispersão equivalente a um desvio padrão, com a mesma unidade de medida do mensurando. Os coeficientes de sensibilidade são calculados através das derivadas parciais de $\mathrm{Y}$ em relação a cada variável $X$.

\subsubsection{Incerteza associada à curva analítica}

São várias as fontes de incerteza que atuam sobre a curva analítica. Neste trabalho, para o cálculo das incertezas associadas à curva analítica consideraram-se as incertezas vinculadas à preparação da solução padrão, às diluições das soluções de trabalho e às áreas obtidas como resposta do equipamento.

Incerteza associada à solução padrão

Para os padrões analíticos sólidos (pentaclorofenol, bisfenol A e benzo[a]pireno) as incertezas envolvidas no cálculo da incerteza da solução padrão foram as da massa, da pureza do padrão e do volume do balão.

A incerteza da balança, do peso padrão e de repetitividade foram

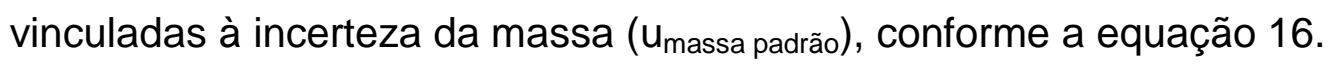




$$
u_{\text {massa padrão }}=\sqrt{\left(u_{\text {repe }}\right)^{2}+\left(u_{\text {peso padrão }}\right)^{2}+\left(u_{\text {calib.balança }}\right)^{2}}
$$

Para a estimativa da incerteza da pureza do padrão analítico foi considerada a pureza declarada pelo fabricante dividida pela raiz de 3 (distribuição retangular).

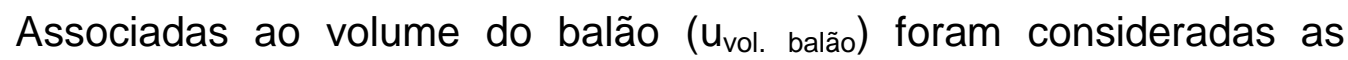
incertezas vinculadas à informação do fabricante, repetições, variação de temperatura e coeficiente de dilatação do vidro, de acordo com a equação 17.

$$
u_{\text {vol.balão }}=\sqrt{\left(u_{\text {repe }}\right)^{2}+\left(u_{\text {fabricante }}\right)^{2}+\left(u_{\Delta t}\right)^{2}+\left(u_{\text {coef.dilatação }}\right)^{2}}
$$

O valor da incerteza relacionada à dilatação do vidro, comparada às demais, é tão insignificante $(<0,04 \%)$ que pode ser desprezada no cálculo.

A incerteza combinada da preparação da solução padrão ( $u_{\mathrm{C}}$ (sol.padrão) foi calculada pela equação 18 .

$$
u_{C(\text { sol.padrão })}=\sqrt{\left(u_{\text {massapadrão }}\right)^{2}+\left(u_{\text {purezapadrão }}\right)^{2}+\left(u_{\text {vol.balão }}\right)^{2}}
$$

Para os padrões analíticos líquidos (dietilftalato, dibutilftalato e nonilfenol) foram consideradas as incertezas referentes à pureza do padrão e ao volume do balão. A equação 19 foi utilizada no cálculo da incerteza combinada associada à solução padrão para estes compostos. Para o cálculo da incerteza do volume do balão foi considerada a equação 17.

$$
u_{C(\text { sol.padrão })}=\sqrt{\left(u_{\text {pureza padrão }}\right)^{2}+\left(u_{\text {vol.baläo }}\right)^{2}}
$$

\section{$\underline{\text { Incerteza associada à preparação das soluções de trabalho }}$}

As fontes de incerteza envolvidas no cálculo das incertezas associadas à preparação das soluções de trabalho são o volume dos balões a os volumes pipetados. Para ambas as fontes de incerteza é necessário considerar as 
informações dos fabricantes, repetições, variações de temperatura e coeficiente de dilatação. Os cálculos seguiram a equação 17.

As incertezas de cada uma das diluições são consideradas no cálculo da incerteza combinada da preparação das soluções de trabalho, conforme a equação 20.

$$
u_{C(\text { sol.trab. })}=C_{\text {sol.trab. }} \sqrt{\left(\frac{u\left(V_{\text {sol.estoque }}\right)}{V_{\text {sol.estoque }}}\right)^{2}+\left(\frac{u\left(V_{10}\right)}{V_{10}}\right)^{2}+\left(\frac{u\left(C_{\text {sol.estoque }}\right)}{C_{\text {sol.estoque }}}\right)^{2}} \text { (eq. 20) }
$$

onde:

$\mathrm{C}_{\text {sol.trab. }}=$ concentração da solução mista de trabalho;

$\mathrm{uV}_{\text {sol.estoque }}=$ incerteza do volume pipetado da solução estoque individual para preparação da solução mista;

$\mathrm{V}_{\text {sol.estoque }}=$ volume pipetado da solução estoque individual para preparação da solução mista;

$\mathrm{uV}_{10}$ = incerteza do volume final da solução mista de trabalho;

$\mathrm{V}_{10}=$ volume final da solução mista de trabalho;

$\mathrm{uC}_{\text {sol.estoque }}=$ incerteza da solução estoque de cada composto;

$\mathrm{C}_{\text {sol.estoque }}=$ concentração da solução estoque de cada composto.

As concentrações das soluções de trabalho foram obtidas pela equação 21.

$$
C_{\text {sol.trab }}=C_{\text {sol.estoque }} \cdot \frac{V_{\text {estoque }}}{V_{10}}
$$

$\underline{\text { Incerteza associada à resposta do equipamento (área) }}$

Para o cálculo da incerteza vinculada à área obtida como resposta do equipamento de GC/MS foram consideradas as incertezas da repetitividade e do equipamento, neste caso, considerou-se a resolução do equipamento.

Seguindo-se a equação 22 , obteve-se a incerteza para a repetitividade (urepe) das injeções no GC/MS. 


$$
u_{\text {repe }}=\frac{s}{\sqrt{n}}
$$

onde:

$\mathrm{S}=$ desvio padrão das medições;

$\mathrm{n}=$ número de injeções realizadas.

A incerteza do equipamento (U uequip.) foi calculada dividindo-se a resolução do GC/MS a meia altura base do pico cromatográfico por raiz de 3 (distribuição retangular).

A incerteza combinada da resposta do equipamento foi obtida pela equação 23.

$$
u_{C(\text { área })}=\sqrt{\left(u_{\text {repe }}\right)^{2}+\left(u_{\text {equip. }}\right)^{2}}
$$

\subsubsection{Incerteza associada à recuperação}

A incerteza combinada relacionada à recuperação $\left(\mathrm{U}_{\mathrm{C}(\mathrm{rec})}\right)$ dos analitos foi calculada pela equação 24 .

$$
u_{C(\text { rec })}=R \sqrt{\left(\frac{u\left(C_{\text {real }}\right)}{C_{\text {real }}}\right)^{2}+\left(\frac{u\left(C_{\text {obtida }}\right)}{C_{\text {obtida }}}\right)^{2}}
$$

onde:

$\mathrm{R}=$ valor da recuperação;

$\mathrm{u}\left(\mathrm{C}_{\text {real }}\right)$ = incerteza da solução padrão adicionada;

$\mathrm{C}_{\text {real }}=$ concentração real adicionada;

$\mathrm{u}\left(\mathrm{C}_{\text {obtida }}\right)$ = incerteza da concentração obtida;

$\mathrm{C}_{\text {obtida }}=$ concentração obtida.

A incerteza da solução padrão adicionada, $u\left(C_{\text {real }}\right)$, é calculada pela equação 20 , enquanto que a incerteza da concentração obtida, $u\left(C_{\text {obtida}}\right)$, é calculada de acordo com a equação 25. 


$$
u_{\text {Cobtida }}=\frac{s_{r e c}}{\sqrt{n}}
$$

onde:

$\mathrm{S}_{\mathrm{rec}}=$ desvio padrão dos ensaios de recuperação;

$\mathrm{n}=$ número de ensaios de recuperação.

\subsubsection{Incerteza associada ao volume final}

As incertezas consideradas no volume final da amostras são as vinculadas ao balão volumétrico de $1 \mathrm{~mL}$, ou seja, às referentes às informações do fabricante, variações de temperatura e ao coeficiente de dilatação térmica, conforme a equação 26.

$$
u_{C(V F)}=\sqrt{\left(u_{\text {fabricante }}\right)^{2}+\left(u_{\text {repe }}\right)^{2}+\left(u_{\Delta t}\right)^{2}+\left(u_{\text {coef.dilatação }}\right)^{2}}
$$

\subsubsection{Incerteza combinada e expandida}

A equação 27 expressa a incerteza combinada de todas as fontes de incertezas envolvidas na concentração dos xenoestrógenos nas amostras de água tratada e água bruta, onde foram consideradas as incertezas da curva analítica ( $\left.u_{\text {curva }}\right)$, da recuperação $\left(u_{r e c}\right)$ e do volume final $\left(u_{V F}\right)$.

$$
u\left(C_{\text {xeno }}\right)=C_{\text {xeno }} \sqrt{\left(\frac{u\left(C_{x}\right)}{C_{x}}\right)^{2}+\left(\frac{u\left(V_{f}\right)}{V_{f}}\right)^{2}+\left(\frac{u\left(V_{\text {amostra }}\right)}{V_{\text {amostra }}}\right)^{2}+\left(\frac{u(R)}{R}\right)^{2}}
$$

Para o cálculo da incerteza expandida multiplicou-se a incerteza combinada pelo fator de abrangência $k$, de acordo com a equação 28 . Neste estudo considerou-se $\mathrm{k}=1,96$, ou seja, com um nível de confiança de $95 \%$.

$$
u_{E(\text { xenoestrógnos })}=u_{C(\text { xenoestrágnos })} \cdot k
$$




\subsection{ANÁLISE de AMOSTRAS REAIS}

\subsubsection{Coleta e preparação das amostras do rio Paraíba do Sul}

Para avaliação da qualidade das águas do rio Paraíba do Sul foram feitas três coletas que abrangeram períodos de seca e chuva, sendo realizadas no início dos meses de junho, setembro e novembro de 2010.

Na FIG. 17 são demonstrados os dados de balanço hídrico semanal de dois dos quatro municípios que compõem a área de estudo, Taubaté e Pindamonhangaba, no ano de 2010 segundo dados do Centro Integrado de Informações Agrometeorológicas (CIIAGRO, 2010).

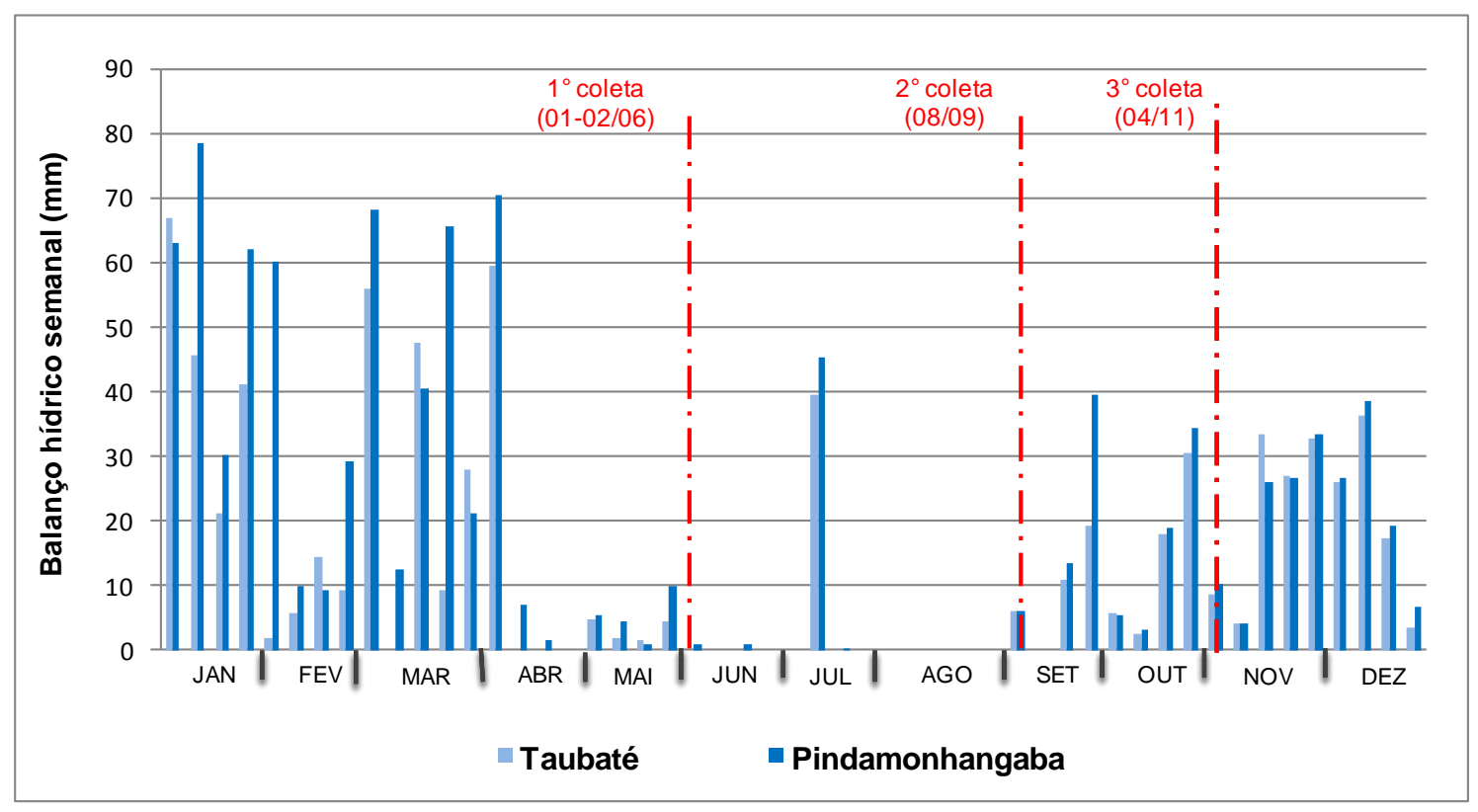

FIGURA 17. Balanço hídrico semanal do ano de 2010, e em destaque as datas das campanhas amostrais (CIIAGRO, 2010).

As amostras de água bruta e tratada foram coletadas diretamente nas Estações de Tratamento de Água (ETA) da Companhia de Saneamento Básico do Estado de São Paulo - SABESP nos municípios de Guararema, São José dos Campos, Taubaté e Pindamonhangaba. Na FIG. 18 pode ser observado o local de amostragem do rio Paraíba do Sul na cidade de Guararema. 

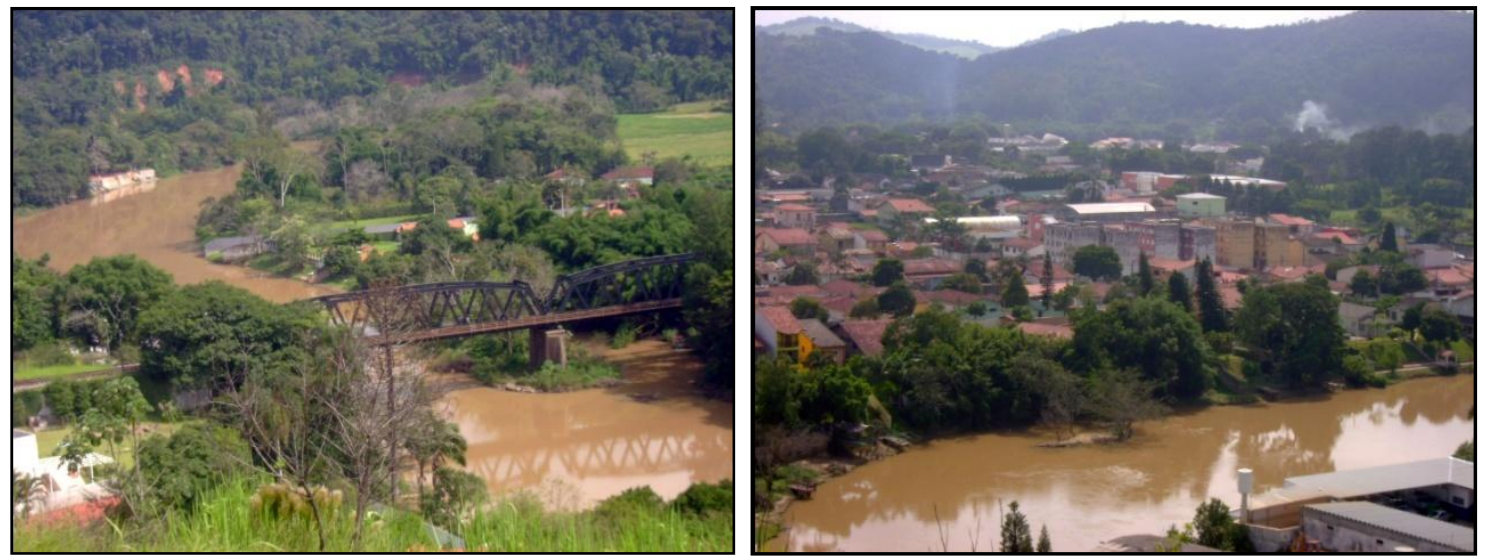

FIGURA 18. Ponto de amostragem na ETA da cidade de Guararema.

Seguindo o Guia de coleta da CETESB (1987), as amostras foram coletadas e armazenadas em frascos de vidro âmbar de $1 \mathrm{~L}$ previamente descontaminados (FIG. 19). Imediatamente após a coleta, os frascos foram colocados em caixas de isopor com gelo (temperatura aproximada de $4^{\circ} \mathrm{C}$ ) e transportados até o laboratório do Centro de Química e Meio Ambiente do Ipen para a análise.
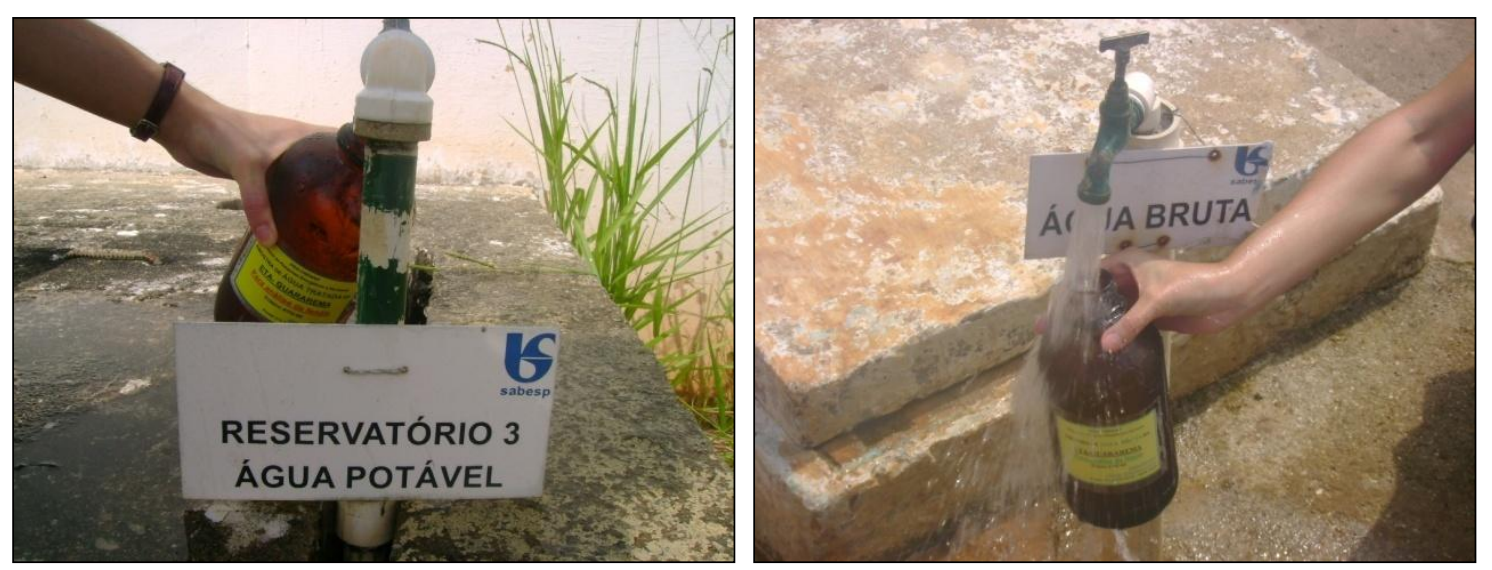

FIGURA 19. Coleta das amostras de água tratada (esquerda) e bruta (direita) em frascos de vidro âmbar na ETA de Guararema.

Em laboratório, adicionou-se $500 \mathrm{mg}$ de tiossulfato de sódio $\left(\mathrm{Na}_{2} \mathrm{~S}_{2} \mathrm{O}_{3}\right)$ às amostras de água tratada a fim de eliminar o cloro presente e preservar os compostos fenólicos. A remoção de partículas em suspensão ocorreu com a filtração das amostras por membranas de nitrocelulose de 0,45 $\mu \mathrm{m}$ em sistema de filtração a vácuo. Após esta etapa, as amostras foram acidificadas para pH 3 com solução de ácido clorídrico $50 \%\left(\mathrm{HCl} / \mathrm{H}_{2} \mathrm{O} 1: 1, \mathrm{v} / \mathrm{v}\right)$ e extraídas seguindo o 
procedimento descrito no item 5.3.2 ou armazenadas em geladeira, também a $4^{\circ} \mathrm{C}$, pelo período máximo de 7 dias, em conformidade com os métodos da USEPA (2007a, 2007b).

\subsubsection{Outras aplicações da metodologia: avaliação de plastificantes em amostras de água mineral e mamadeira}

No decorrer do desenvolvimento desta pesquisa, percebeu-se que muitos estudos publicados investigavam a contaminação de amostras de água mineral por ftalatos, bisfenol A e nonilfenol (Casajuana e Lacote, 2003; Li et al., 2010; Diana e Dimitra, 2011), e outros avaliavam a migração do bisfenol $A$ de mamadeiras, as quais são fabricadas com o plástico policarbonato (Li et al., 2010; Nam et al., 2010).

Dessa forma, após a metodologia estar definida e validada, a mesma foi aplicada em amostras de água mineral antes e depois de estocadas para avaliar a liberação de plastificantes durante 0 armazenamento. Também foi investigada a presença e liberação de BPA de uma mamadeira nova e quando submetida a ciclos de aquecimento em forno micro-ondas.

As amostras de água mineral em garrafas PET (polietileno tereftalato) foram adquiridas diretamente no posto de venda. Uma amostra foi imediatamente extraída após a compra (intervalo da data de envase e análise de 15 dias) e a outra foi armazenada em condições ambientais, porém protegida da luminosidade direta, sendo analisada após 60 dias da data de envase. Para extração, as amostras foram avolumadas para $1 \mathrm{~L}$, acidificadas para $\mathrm{pH} 3 \mathrm{com}$ solução de ácido clorídrico $50 \%\left(\mathrm{HCl} / \mathrm{H}_{2} \mathrm{O} 1: 1, \mathrm{v} / \mathrm{v}\right)$ e extraídas seguindo o procedimento do item 5.3.2.

A mamadeira de policarbonato foi adquirida no posto de venda, assim como as amostras de água mineral. Embora os fabricantes não recomendem o aquecimento da mamadeira em micro-ondas por poder haver gradiente de temperatura no líquido aquecido e queimadura na criança, muitas mães fazem 
uso desta facilidade. Para avaliação da migração de BPA em diferentes temperaturas e após o uso, foram preparadas três amostras:

$\checkmark$ Para compor a primeira amostra, $250 \mathrm{~mL}$ de água ultrapura (tipo 1) foram aquecidos na mamadeira por 1 minuto em forno micro-ondas em potência alta, onde a temperatura chegou a cerca de $55^{\circ} \mathrm{C}$. Esse procedimento foi realizado quatro vezes para se obter o volume de $1 \mathrm{~L}$ de amostra para concentração e análise;

$\checkmark$ Nos quatro aquecimentos que se seguiram, a mamadeira, com $250 \mathrm{~mL}$ de água ultrapura (tipo 1), foi aquecida por 2 minutos e 30 segundos em forno micro-ondas também em potência alta, chegando à temperatura aproximada de $90^{\circ} \mathrm{C}$;

$\checkmark$ A terceira amostra foi composta após 60 ciclos de aquecimento, para avaliar se depois de utilizações sucessivas poderia haver liberação do BPA. Então foram coletadas 4 alíquotas de $250 \mathrm{~mL}$ aquecidas também por 2 minutos e 30 segundos em forno micro-ondas e em potência máxima.

As amostras foram resfriadas em temperatura ambiente, em seguida foram acidificadas para pH 3 com solução de ácido clorídrico $50 \%\left(\mathrm{HCl} / \mathrm{H}_{2} \mathrm{O} 1: 1\right.$, $\mathrm{v} / \mathrm{v}$ ) e extraídas seguindo o procedimento descrita no item 5.3.2. 


\section{RESULTADOS E DISCUSSÃO}

\subsection{OTIMIZAÇÃO dA METOdOLOGIA DE EXTRAÇÃo POR SPE}

A extração e a concentração dos compostos disruptores endócrinos das matrizes aquosas foram realizadas empregando-se a técnica de extração em fase sólida (SPE), de acordo com o método final descrito no item 5.3.2.

Para definição da metodologia, vários parâmetros da extração dos xenoestrógenos foram avaliados: tipo de cartucho - OASIS HBL (1 mL da Waters) ou ENVI $\mathrm{C}_{18}(6 \mathrm{~mL})$ da Supelclean, solvente para condicionamento do cartucho, etapa de lavagem (clean up), pH da amostra e solvente de eluição, de acordo com o descrito no item 5.3.1.

$\mathrm{Na}$ primeira etapa dos ensaios foram feitos testes qualitativos utilizando-se água ultrapura fortificada com a mistura dos padrões analíticos, apenas por comparação, uma vez que não havia sido preparada uma curva analítica para quantificação. Dessa forma, as injeções dos testes foram realizadas no modo SCAN do equipamento de GC/MS, e os cromatogramas obtidos comparados com o cromatograma da solução mix dos seis padrões na mesma concentração adicionada à amostra anteriormente à extração. Os resultados obtidos são apresentados na FIG 20.

Os melhores resultados foram alcançados quando foi utilizado o cartucho preenchido com $\mathrm{C}_{18}$, o que pode estar relacionado ao volume do cartucho, de $6 \mathrm{~mL}$ de capacidade contra apenas $1 \mathrm{~mL}$ do cartucho OASIS HBL. Os testes 2 e 5, descritos na TAB. 6 do capítulo 5, apresentaram recuperações muito elevadas para todos os compostos, enquanto que aplicando-se o teste 4 foi obtida uma recuperação satisfatória apenas para o composto dietilftalato. 


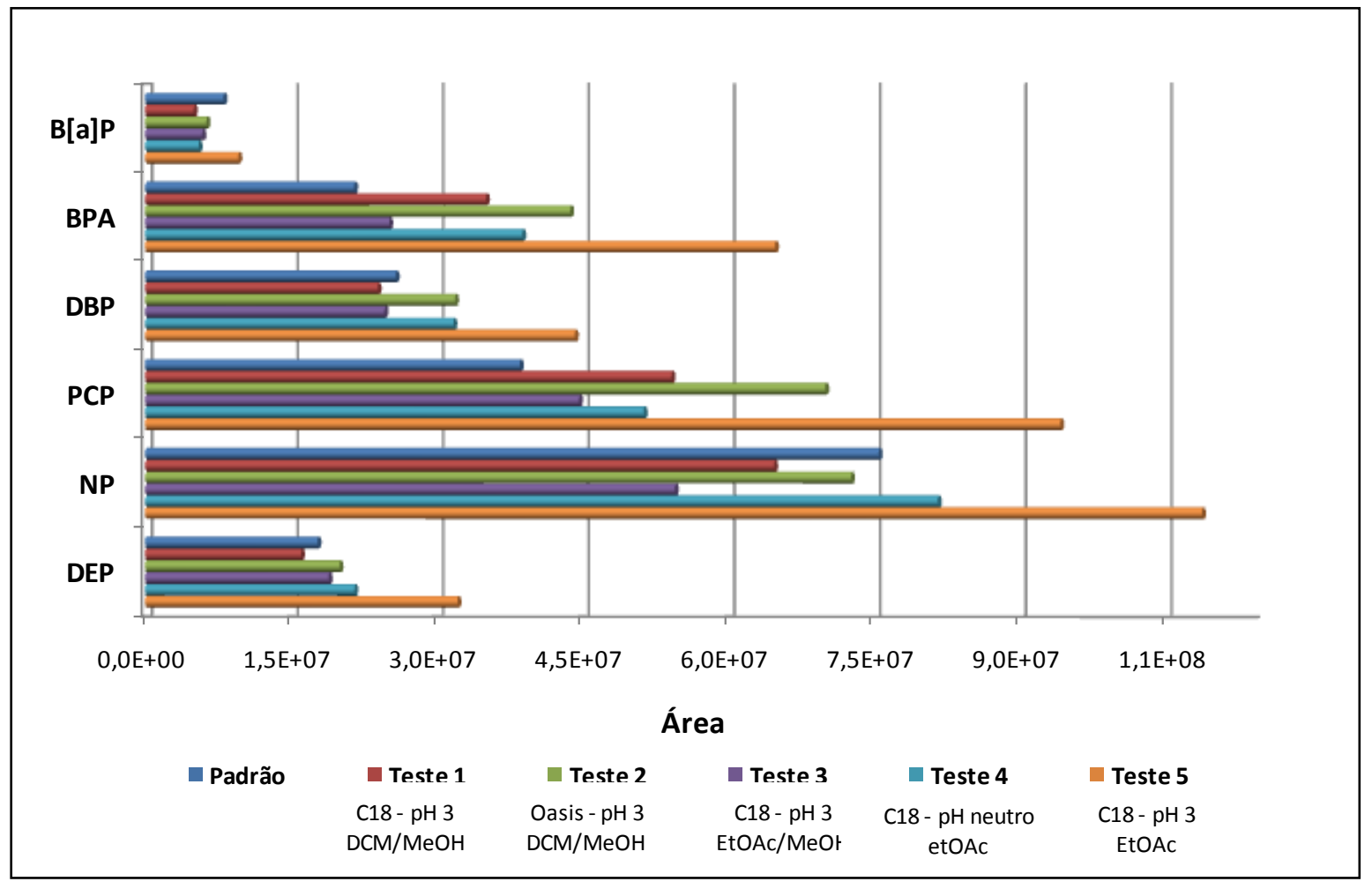

FIGURA 20. Comparação das áreas dos picos cromatográficos dos seis composto estudados com a área dos picos da solução padrão mix.

Os testes 1 e 3 foram os que apresentaram os melhores resultados para a extração simultânea dos 6 compostos. Nestes ensaios, utilizaram-se cartuchos $\mathrm{C}_{18}$, amostras com $\mathrm{pH}$ ácido $(\mathrm{pH} 3)$ e eluição com $5 \mathrm{~mL}$ de $\mathrm{DCM} / \mathrm{MeOH}$ $(60: 40)$ e $2 \times 3 \mathrm{~mL}$ de $\mathrm{EtOAc} / \mathrm{MeOH}$ (60:40), respectivamente. Dessa forma, estes testes foram escolhidos para os testes qualitativos.

Após obtenção das curvas analíticas, foram realizados novos ensaios para definição da metodologia de extração. Como mencionado anteriormente, nesta etapa utilizou-se amostra de água tratada provenientes dos pontos de amostragem para avaliação da interferência da matriz. Os parâmetros modificados foram $\mathrm{o} \mathrm{pH}$ da amostra e a lavagem do cartucho SPE após a percolação da amostra. O tipo de cartucho, assim como seu condicionamento e eluição dos analitos foi mantido conforme os testes 1 e 3. 
Como pode ser observado na FIG. 21 os resultados de recuperação obtidos para os testes 6 a 11 (descritos na TAB. 7 do item 5.3.1) variaram significativamente para todos os compostos.

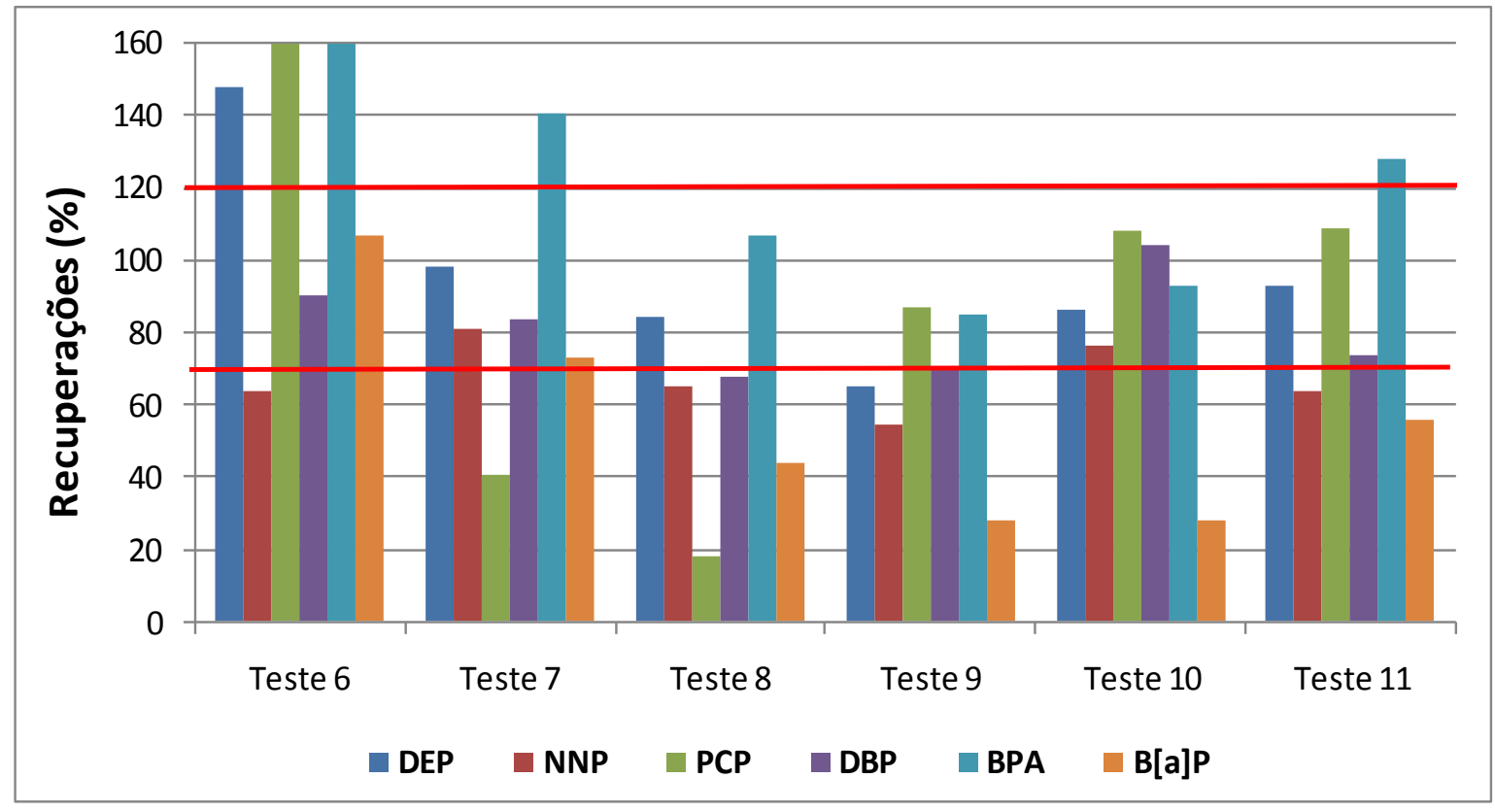

FIGURA 21. Comparação das porcentagens de recuperação obtidas pelos testes de extração 6 a 11. As linhas vermelhas indicam o valor mínimo (70\%) e máximo (120\%) aceitos para análise de resíduos.

O teste 6 , onde não foi realizada a etapa de lavagem do cartucho e se empregou a solução $\mathrm{DCM} / \mathrm{MeOH}(60: 40$, v/v) para eluição dos analitos, foi o que apresentou as maiores porcentagens de recuperação para quatro dos seis compostos, todavia, essas recuperações ficaram acima dos $120 \%$ para o dietilftalato (DEP), pentaclorofenol (PCP) e bisfenol A (BPA), evidenciando a interferência da matriz nas determinações.

Quando mantida a eluição com $\mathrm{DCM} / \mathrm{MeOH}(60: 40, \mathrm{v} / \mathrm{v})$, porém realizando-se a lavagem do cartucho (Teste 7), obteve-se bons valores de recuperação para os ftalatos, assim como para o nonilfenol (NP) e o benzo[a]pireno (B[a]P). Entretanto, para o BPA a recuperação foi elevada (140\%), e baixa para o PCP (40\%), também evidenciando a interferência da matriz.

No teste 8 a recuperação foi satisfatória apenas para os compostos DEP e BPA. Este ensaio apresentou a menor recuperação para o PCP (18\%), o 
que pode estar relacionado ao $\mathrm{pH}$ neutro da amostra, já que neste testes, assim como no teste 7 , o $\mathrm{pH}$ foi ajustado para 7.

Os testes 9, 10 e 11 foram os que resultaram em melhores recuperações dos analitos. Apesar da baixa recuperação do $\mathrm{B}[\mathrm{a}] \mathrm{P}$ no ensaio 10 , este método foi escolhido por apresentar porcentagens de recuperação entre 70 e $120 \%$ para os outros cinco compostos avaliados.

A metodologia definida permite a concentração de 1000 vezes a amostra (volume inicial de $1 \mathrm{~L}$ de amostra resultando em $1 \mathrm{~mL}$ do extrato), assegurando que os limites do equipamento serão alcançados, além de ser similar a maioria dos métodos de extração de DEs por SPE, onde a amostra é acidificada para pH = 3 (Otomo, 2010; Yu, 2007; Mol, 2000). Porém, neste método proposto um menor volume de solventes é empregado tanto no condicionamento do cartucho, quanto na eluição dos analitos quando comparado a outras metodologias (Moreira, 2008; Hernando, 2004).

\subsection{VALIDAÇÃO dOS PARÂMETROS ANALítICOS}

Como mencionado no item 5.4 desta dissertação, para validação da metodologia foram utilizadas nove alíquotas do extrato das amostras de Guararema, sendo oito fortificadas com a mistura dos padrões analíticos e um adotado como branco das matrizes. Pela análise desses brancos foi possível detectar todos os seis compostos nas amostras de água tratada e quatro compostos (exceto pentaclorofenol e benzo[a]pireno) nas amostras de água bruta. Dessa forma, para uma correta avaliação dos parâmetros estudados, estes resultados, mesmo em baixas concentrações, foram desconsiderados de cada fração fortificada anteriormente à aplicação dos cálculos estatísticos para avaliação de todos os parâmetros. 


\subsubsection{Seletividade}

A seletividade da metodologia foi primeiramente avaliada pela análise cromatográfica da solução mix dos seis padrões analíticos no método cromatográfico definido. Inicialmente a solução foi preparada somente na mistura de solventes (EtOAc:MeOH 60:40, v/v) e posteriormente nas matrizes de água tratada (AT) e água bruta (AB). Nas FIG. 22 e 23 são demonstrados como exemplos os cromatogramas obtidos para os compostos estudados nas duas matrizes referente ao segundo ponto das curvas analíticas, cujas concentrações estão entre $0,05 \mu \mathrm{g} \cdot \mathrm{mL}^{-1}$ e $0,2 \mu \mathrm{g} \cdot \mathrm{mL}^{-1}$.

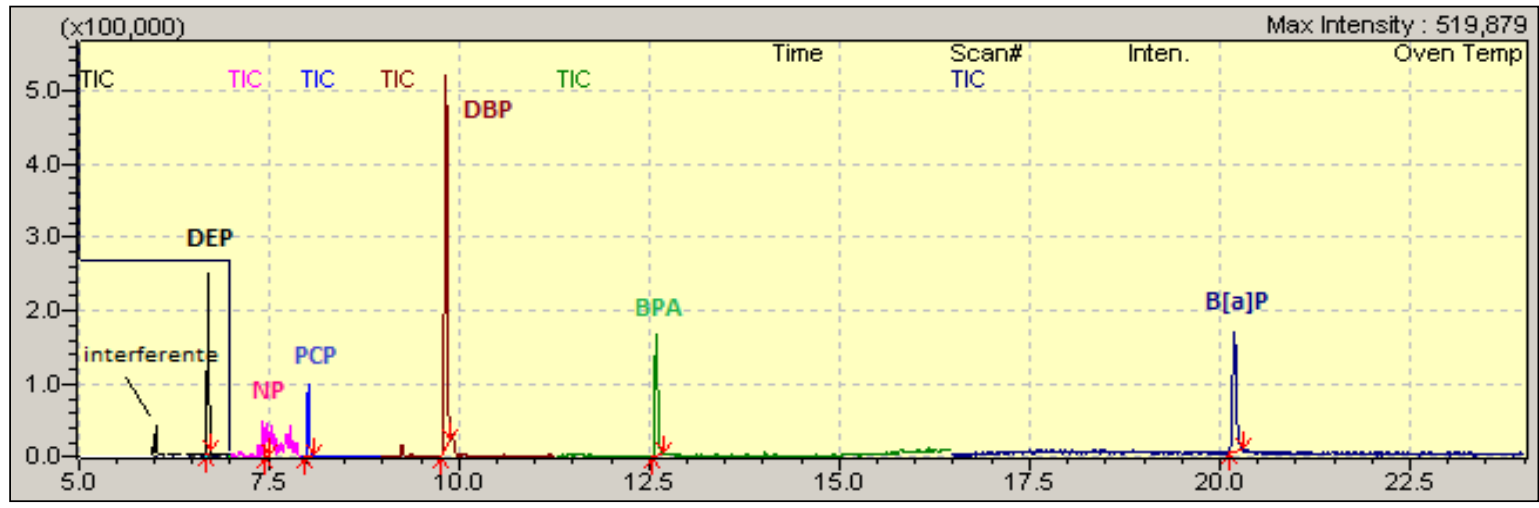

FIGURA 22. Cromatograma da solução mix dos compostos estudados (DEP, dietilftalato; NP, nonilfenol; PCP, pentaclorofenol; DBP; dibutilftalato; BPA, bisfenol A; $\mathrm{B}[\mathrm{a}] \mathrm{P}$, benzo[a]pireno) na matriz de água tratada referente ao segundo ponto da curva analítica obtido no modo SIM.

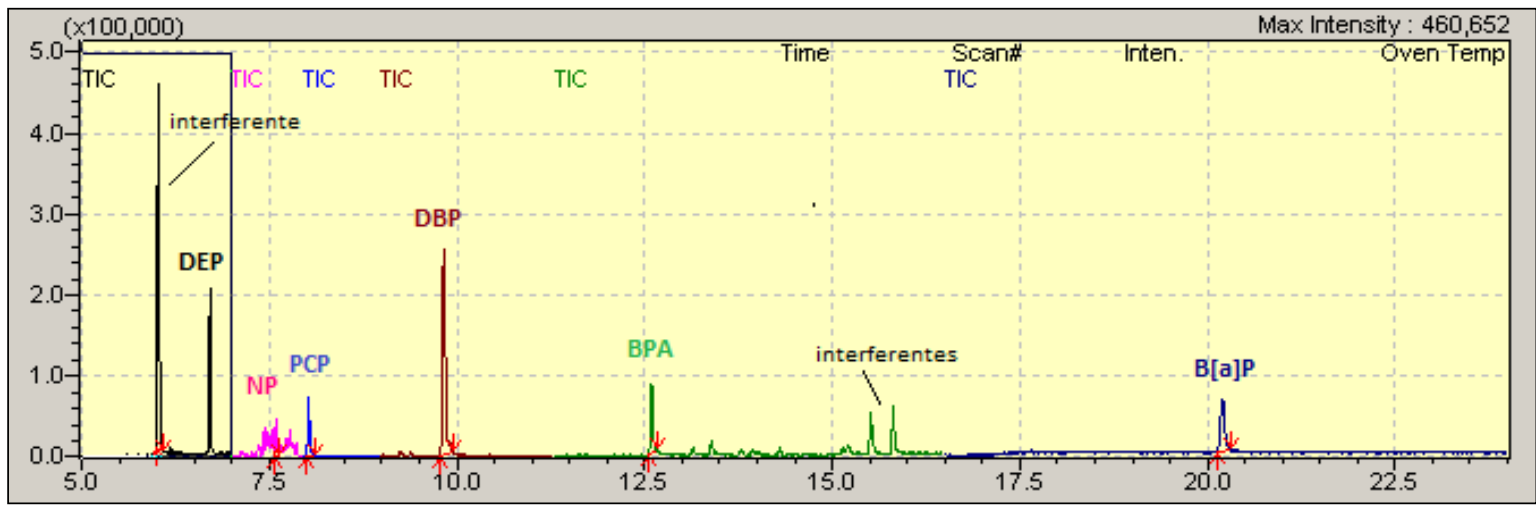

FIGURA 23. Cromatograma da solução mix dos compostos estudados (DEP, dietilftalato; NP, nonilfenol; PCP, pentaclorofenol; DBP; dibutilftalato; BPA, bisfenol A; $\mathrm{B}[\mathrm{a}] \mathrm{P}$, benzo[a]pireno) na matriz de água bruta referente ao segundo ponto da curva analítica obtido no modo SIM. 
Como pode ser observado nas FIG. 22 e 23, apesar de estarem nas mesmas concentrações e na mesma escala de intensidade do equipamento, um maior sinal analítico é obtido para todos os compostos na matriz de água tratada, evidenciando as matrizes interferem de forma diferente na determinação dos compostos estudados. Nota-se ainda que os outros compostos presentes nas matrizes não interferem na corrida cromatográfica, no modo SIM.

$\mathrm{Na}$ FIG. 24 são apresentados os picos cromatográficos dos xenoestrógenos na matriz de água tratada, cujas concentrações referem-se ao segundo ponto das curvas analíticas, demonstrando a boa resolução dos picos, assim como a ótima separação dos analitos durante a análise.

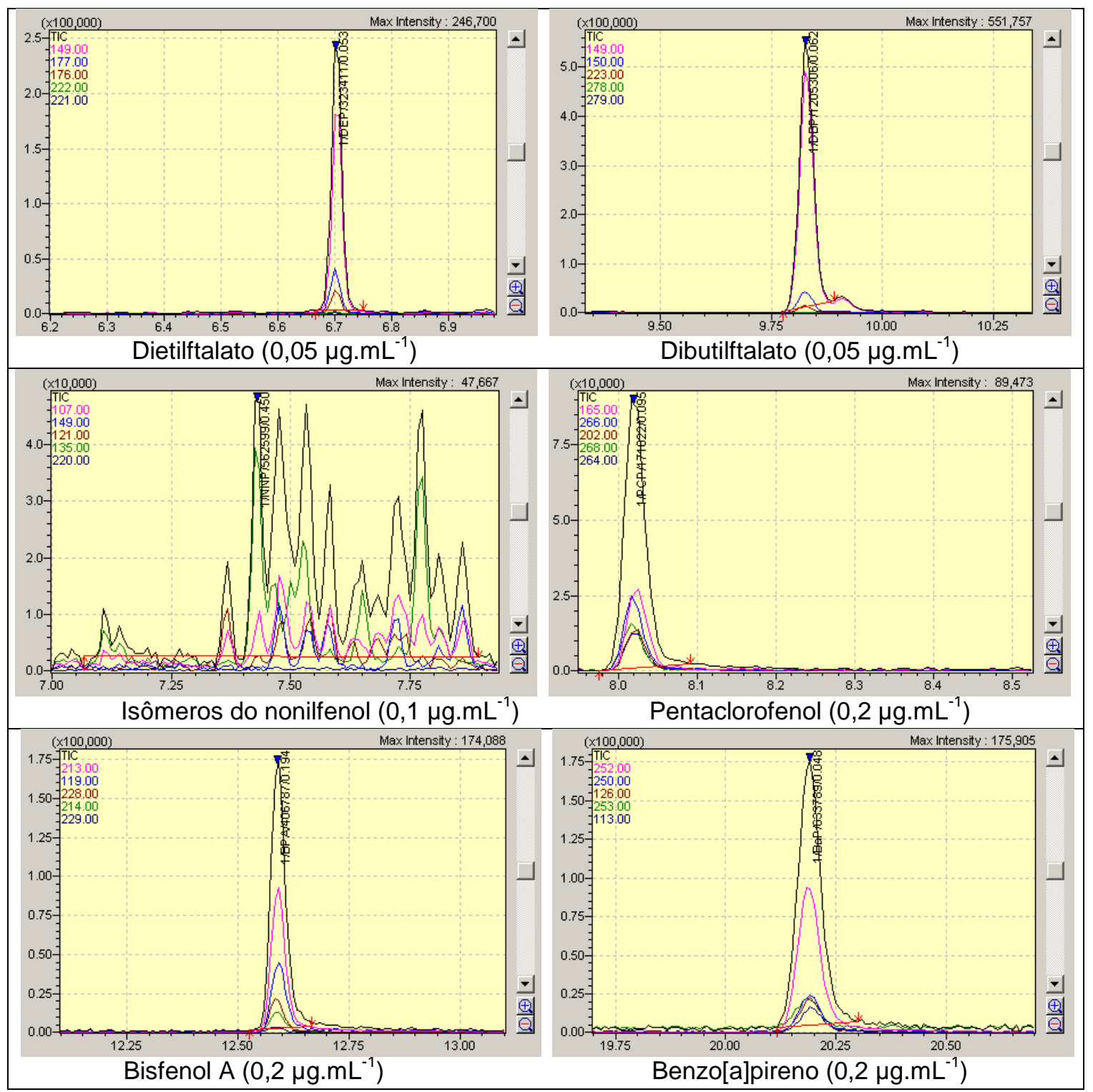

FIGURA 24. Picos cromatográficos dos compostos estudados obtidos no modo SIM, em detalhe à esquerda os íons monitorados. 
O efeito das matrizes sobre o método foi avaliado pelos testes estatísticos F - Snedecor e t - Student, que tiveram suas equações descritas no item 5.4.1 do capítulo 5 desta dissertação. Pela aplicação do teste F (Snedecor) foi analisada a homogeneidade das variâncias nas medidas de adição padrão nas soluções sem matriz (somente nos solventes $\mathrm{EtOAc/MeOH)} \mathrm{e} \mathrm{nas} \mathrm{matrizes} \mathrm{de}$ água tratada e água bruta, considerando sete replicatas $(n=7)$ e $95 \%$ de confiança. O teste de significância das diferenças das médias, ou teste t Student, também foi aplicado nos dois grupos de soluções (com e sem matriz).

Nas TAB. 12 e 13 são apresentados os dados das variâncias $\left(s^{2}\right)$ obtidos nos ensaios sem matriz e com matriz, assim como os resultados dos testes $\mathrm{F}$ e t nas matrizes de água tratada e água bruta, respectivamente, onde os valores calculados foram comparados aos valores tabelados $F_{(6,6,95 \%)}=4,28 \mathrm{e}$ $t_{(12,95 \%)}=2,179$.

TABELA 12. Resultados da seletividade pela aplicação dos testes $F$ e $t$ para os compostos estudados, pela adição padrão somente nos solventes e na matriz de água tratada (AT). Tabela com os resultados dos valores calculados. Considerando $F_{\text {tabelado }}=4,28$ e $t_{\text {tabelado }}=2,179$.

\begin{tabular}{|c|c|c|c|c|c|c|c|c|c|}
\hline \multicolumn{10}{|c|}{ Dietilftalato - Concentração ng.mL ${ }^{-1}$} \\
\hline & [ ] & 25 & 50 & 100 & 200 & 350 & 550 & 750 & 1000 \\
\hline $\begin{array}{c}\text { SEM } \\
\text { matriz }\end{array}$ & $s^{2}$ & $1,67 \mathrm{E}+07$ & $1,76 \mathrm{E}+07$ & $1,91 \mathrm{E}+08$ & $9,66 \mathrm{E}+08$ & $2,26 \mathrm{E}+09$ & $1,25 \mathrm{E}+10$ & $5,68 \mathrm{E}+09$ & $2,24 \mathrm{E}+10$ \\
\hline \multirow{3}{*}{$\begin{array}{c}\text { Matriz } \\
\text { AT }\end{array}$} & $s^{2}$ & $4,17 E+08$ & $2,94 \mathrm{E}+08$ & $1,70 \mathrm{E}+09$ & $1,64 \mathrm{E}+09$ & $1,51 \mathrm{E}+10$ & $1,15 \mathrm{E}+10$ & $2,01 E+10$ & $2,01 E+10$ \\
\hline & $\mathbf{F}_{\text {calc }}$ & 25,00 & 16,67 & 8,88 & 1,70 & 6,70 & 0,92 & 3,54 & 0,90 \\
\hline & $t_{\text {calc }}$ & 2,99 & 10,22 & 2,80 & 19,35 & 6,67 & 18,74 & 14,91 & 19,57 \\
\hline \multicolumn{10}{|c|}{ Dibutilftalato - Concentração ng.mL $\mathrm{m}^{-1}$} \\
\hline & [ ] & 25 & 50 & 100 & 200 & 350 & 550 & 750 & 1000 \\
\hline $\begin{array}{c}\text { SEM } \\
\text { matriz }\end{array}$ & $s^{2}$ & $4,09 \mathrm{E}+07$ & $2,46 \mathrm{E}+07$ & $2,91 \mathrm{E}+08$ & $1,19 \mathrm{E}+09$ & $2,67 \mathrm{E}+09$ & $3,35 \mathrm{E}+10$ & $1,39 \mathrm{E}+10$ & $4,08 \mathrm{E}+10$ \\
\hline \multirow{3}{*}{$\begin{array}{c}\text { Matriz } \\
\text { AT }\end{array}$} & $s^{2}$ & $7,96 \mathrm{E}+09$ & $2,42 E+09$ & $1,38 \mathrm{E}+10$ & $2,73 E+09$ & $5,57 \mathrm{E}+10$ & $1,72 E+10$ & $9,30 \mathrm{E}+10$ & $3,85 E+10$ \\
\hline & $F_{\text {calc }}$ & 194,66 & 98,32 & 47,60 & 2,29 & 20,84 & 0,51 & 6,70 & 0,94 \\
\hline & $\mathbf{t}_{\text {calc }}$ & 4,20 & 18,47 & 7,68 & 39,27 & 12,35 & 26,10 & 15,21 & 25,52 \\
\hline
\end{tabular}


...continuação TABELA 12.

\begin{tabular}{|c|c|c|c|c|c|c|c|c|c|}
\hline \multicolumn{10}{|c|}{ Nonilfenol - Concentração ng.mL ${ }^{-1}$} \\
\hline & [ ] & 50 & 100 & 200 & 400 & 700 & 1100 & 1500 & 2000 \\
\hline $\begin{array}{c}\text { SEM } \\
\text { matriz }\end{array}$ & $s^{2}$ & $2,90 \mathrm{E}+07$ & $2,56 \mathrm{E}+08$ & $5,78 \mathrm{E}+08$ & $2,03 E+09$ & $1,01 \mathrm{E}+10$ & $3,19 \mathrm{E}+10$ & $3,29 \mathrm{E}+10$ & $7,10 \mathrm{E}+10$ \\
\hline \multirow{3}{*}{$\begin{array}{c}\text { Matriz } \\
\text { AT }\end{array}$} & $s^{2}$ & $8,61 \mathrm{E}+08$ & $1,19 \mathrm{E}+09$ & $7,92 \mathrm{E}+09$ & $4,76 \mathrm{E}+09$ & $1,00 \mathrm{E}+11$ & $6,39 E+10$ & $1,83 \mathrm{E}+11$ & $1,94 \mathrm{E}+11$ \\
\hline & $\mathbf{F}_{\text {calc }}$ & 29,67 & 4,65 & 13,71 & 2,35 & 9,94 & 2,00 & 5,56 & 2,73 \\
\hline & $t_{\text {calc }}$ & 10,15 & 16,03 & 9,96 & 37,58 & 12,99 & 33,26 & 22,75 & 31,38 \\
\hline \multicolumn{10}{|c|}{ Pentaclorofenol - Concentração ng.mL ${ }^{-1}$} \\
\hline & [ ] & 100 & 200 & 400 & 800 & 1400 & 2200 & 3000 & 4000 \\
\hline \multirow{2}{*}{$\begin{array}{c}\text { SEM } \\
\text { matriz }\end{array}$} & $s^{2}$ & $4,05 \mathrm{E}+07$ & $1,40 \mathrm{E}+08$ & $1,42 \mathrm{E}+08$ & $6,37 \mathrm{E}+08$ & $1,56 \mathrm{E}+09$ & $5,33 E+09$ & $5,60 \mathrm{E}+09$ & $1,66 \mathrm{E}+10$ \\
\hline & $\mathrm{s}^{2}$ & $2,42 \mathrm{E}+08$ & $4,04 \mathrm{E}+08$ & $2,25 \mathrm{E}+09$ & $7,86 \mathrm{E}+09$ & $3,23 E+10$ & $2,62 \mathrm{E}+10$ & $9,07 \mathrm{E}+10$ & $6,53 \mathrm{E}+10$ \\
\hline \multirow{2}{*}{$\begin{array}{c}\text { Matriz } \\
\text { AT }\end{array}$} & $\mathbf{F}_{\text {calc }}$ & 5,97 & 2,88 & 15,78 & 12,33 & 20,65 & 4,91 & 16,18 & 3,94 \\
\hline & $t_{\text {calc }}$ & 5,13 & 3,31 & 16,73 & 8,52 & 14,00 & 10,21 & 20,20 & 10,53 \\
\hline \multicolumn{10}{|c|}{ Bisfenol A - Concentração ng. $\mathrm{mL}^{-1}$} \\
\hline & [ ] & 100 & 200 & 400 & 800 & 1400 & 2200 & 3000 & 4000 \\
\hline $\begin{array}{c}\text { SEM } \\
\text { matriz }\end{array}$ & $s^{2}$ & $2,52 \mathrm{E}+06$ & $3,10 \mathrm{E}+07$ & $1,56 \mathrm{E}+08$ & $5,50 \mathrm{E}+08$ & $5,69 \mathrm{E}+09$ & $2,17 E+10$ & $3,18 \mathrm{E}+10$ & $1,17 \mathrm{E}+11$ \\
\hline \multirow{3}{*}{$\begin{array}{l}\text { Matriz } \\
\text { AT }\end{array}$} & $s^{2}$ & $5,78 \mathrm{E}+08$ & $2,13 \mathrm{E}+09$ & $6,63 \mathrm{E}+09$ & $3,13 \mathrm{E}+10$ & $9,49 \mathrm{E}+10$ & $1,10 \mathrm{E}+11$ & $1,49 \mathrm{E}+11$ & $2,87 \mathrm{E}+11$ \\
\hline & $\mathbf{F}_{\text {calc }}$ & 229,10 & 68,75 & 42,47 & 56,89 & 16,66 & 5,04 & 4,71 & 2,46 \\
\hline & $t_{\text {calc }}$ & 11,15 & 15,79 & 11,72 & 18,65 & 11,23 & 27,50 & 13,30 & 16,73 \\
\hline \multicolumn{10}{|c|}{ Benzo[a]pireno - Concentração $\mathrm{ng} \cdot \mathrm{mL}^{-1}$} \\
\hline & [ ] & 100 & 200 & 400 & 800 & 1400 & 2200 & 3000 & 4000 \\
\hline $\begin{array}{c}\text { SEM } \\
\text { matriz }\end{array}$ & $s^{2}$ & $2,64 \mathrm{E}+07$ & $2,13 \mathrm{E}+08$ & $9,01 \mathrm{E}+08$ & $1,53 \mathrm{E}+09$ & $3,31 \mathrm{E}+10$ & $1,40 \mathrm{E}+11$ & $1,25 \mathrm{E}+11$ & $4,48 \mathrm{E}+11$ \\
\hline \multirow{3}{*}{$\begin{array}{l}\text { Matriz } \\
\text { AT }\end{array}$} & $s^{2}$ & 1,67E+09 & $4,70 \mathrm{E}+09$ & $6,70 \mathrm{E}+09$ & $4,94 \mathrm{E}+10$ & $1,23 \mathrm{E}+11$ & $3,77 \mathrm{E}+10$ & $7,60 \mathrm{E}+10$ & $1,29 \mathrm{E}+11$ \\
\hline & $\mathbf{F}_{\text {calc }}$ & 63,41 & 22,07 & 7,44 & 32,27 & 3,72 & 0,27 & 0,61 & 0,29 \\
\hline & $t_{\text {calc }}$ & 16,14 & 17,93 & 19,14 & 15,67 & 0,02 & 11,81 & 15,49 & 8,02 \\
\hline
\end{tabular}

TABELA 13. Resultados da seletividade pela aplicação dos testes $F$ e $t$ para os compostos estudados, pela adição padrão somente nos solventes e na matriz de água bruta (AB). Tabela com os resultados dos valores calculados. Considerando $F_{\text {tabelado }}=4,28$ e $t_{\text {tabelado }}=2,179$.

\begin{tabular}{cccccccccc}
\hline \multicolumn{10}{c}{ Dietilftalato - Concentração $\mathbf{n g} \cdot \mathbf{m L}^{-1}$} \\
\hline & {[]} & 25 & 50 & 100 & 200 & 350 & 550 & 750 & 1000 \\
\hline SEM & $s^{2}$ & $1,67 \mathrm{E}+07$ & $1,76 \mathrm{E}+07$ & $1,91 \mathrm{E}+08$ & $9,66 \mathrm{E}+08$ & $2,26 \mathrm{E}+09$ & $1,25 \mathrm{E}+10$ & $5,68 \mathrm{E}+09$ & $2,24 \mathrm{E}+10$ \\
\hline \multirow{2}{*}{ Matriz } & $\mathrm{s}^{2}$ & $5,19 \mathrm{E}+07$ & $1,26 \mathrm{E}+08$ & $5,50 \mathrm{E}+08$ & $5,67 \mathrm{E}+08$ & $8,59 \mathrm{E}+09$ & $1,75 \mathrm{E}+10$ & $7,93 \mathrm{E}+10$ & $6,36 \mathrm{E}+10$ \\
\cline { 2 - 10 } $\mathrm{AB}$ & $\mathbf{F}_{\text {calc }}$ & $\mathbf{3 , 1 1}$ & $\mathbf{7 , 1 7}$ & $\mathbf{2 , 8 8}$ & $\mathbf{0 , 5 9}$ & $\mathbf{3 , 8 0}$ & $\mathbf{1 , 4 0}$ & $\mathbf{1 3 , 9 5}$ & $\mathbf{2 , 8 5}$ \\
& $\mathbf{t}_{\text {calc }}$ & $\mathbf{5 , 5 9}$ & $\mathbf{8 , 5 6}$ & $\mathbf{0 , 6 6}$ & $\mathbf{1 6 , 5 4}$ & $\mathbf{4 , 2 9}$ & $\mathbf{9 , 3 4}$ & $\mathbf{2 , 4 5}$ & $\mathbf{6 , 9 1}$ \\
\hline
\end{tabular}


...continuação TABELA 13.

\begin{tabular}{|c|c|c|c|c|c|c|c|c|c|}
\hline \multicolumn{10}{|c|}{ Dibutilftalato - Concentração ng.mL ${ }^{-1}$} \\
\hline & [ ] & 25 & 50 & 100 & 200 & 350 & 550 & 750 & 1000 \\
\hline $\begin{array}{c}\text { SEM } \\
\text { matriz }\end{array}$ & $s^{2}$ & $4,09 \mathrm{E}+07$ & $2,46 \mathrm{E}+07$ & $2,91 \mathrm{E}+08$ & 1,19E+09 & $2,67 \mathrm{E}+09$ & $3,35 E+10$ & $1,39 E+10$ & $4,08 \mathrm{E}+10$ \\
\hline \multirow{3}{*}{$\begin{array}{c}\text { Matriz } \\
\text { AB }\end{array}$} & $s^{2}$ & $3,79 \mathrm{E}+08$ & $3,79 \mathrm{E}+08$ & $2,26 \mathrm{E}+09$ & $8,28 \mathrm{E}+08$ & $5,06 \mathrm{E}+10$ & $8,62 \mathrm{E}+10$ & $2,90 \mathrm{E}+11$ & $1,78 \mathrm{E}+11$ \\
\hline & $\mathbf{F}_{\text {calc }}$ & 9,28 & 15,42 & 7,78 & 0,70 & 18,94 & 2,57 & 20,85 & 4,37 \\
\hline & $t_{\text {calc }}$ & 5,49 & 19,38 & 8,35 & 28,36 & 6,61 & 9,34 & 3,82 & 7,48 \\
\hline \multicolumn{10}{|c|}{ Nonilfenol - Concentração ng.mL ${ }^{-1}$} \\
\hline & [ ] & 50 & 100 & 200 & 400 & 700 & 1100 & 1500 & 2000 \\
\hline $\begin{array}{c}\text { SEM } \\
\text { matriz }\end{array}$ & $s^{2}$ & $2,90 \mathrm{E}+07$ & $2,56 \mathrm{E}+08$ & $5,78 \mathrm{E}+08$ & $2,03 E+09$ & $1,01 \mathrm{E}+10$ & $3,19 \mathrm{E}+10$ & $3,29 E+10$ & $7,10 \mathrm{E}+10$ \\
\hline \multirow{3}{*}{$\begin{array}{c}\text { Matriz } \\
\text { AB }\end{array}$} & $s^{2}$ & $1,11 \mathrm{E}+09$ & $4,32 \mathrm{E}+08$ & $4,56 \mathrm{E}+09$ & $2,94 \mathrm{E}+09$ & $5,45 \mathrm{E}+10$ & $1,51 \mathrm{E}+11$ & $3,86 \mathrm{E}+11$ & $5,33 E+11$ \\
\hline & $\mathbf{F}_{\text {calc }}$ & 38,22 & 1,68 & 7,89 & 1,45 & 5,40 & 4,73 & 11,73 & 7,51 \\
\hline & $t_{\text {calc }}$ & 3,83 & 11,49 & 3,19 & 22,56 & 6,53 & 11,44 & 6,95 & 10,71 \\
\hline \multicolumn{10}{|c|}{ Pentaclorofenol - Concentração ng.mL ${ }^{-1}$} \\
\hline & [ ] & 100 & 200 & 400 & 800 & 1400 & 2200 & 3000 & 4000 \\
\hline $\begin{array}{c}\text { SEM } \\
\text { matriz }\end{array}$ & $s^{2}$ & $4,05 \mathrm{E}+07$ & $1,40 \mathrm{E}+08$ & $1,42 \mathrm{E}+08$ & $6,37 \mathrm{E}+08$ & $1,56 \mathrm{E}+09$ & $5,33 E+09$ & $5,60 \mathrm{E}+09$ & $1,66 \mathrm{E}+10$ \\
\hline \multirow{3}{*}{$\begin{array}{c}\text { Matriz } \\
\text { AB }\end{array}$} & $s^{2}$ & $1,62 \mathrm{E}+07$ & $1,24 \mathrm{E}+08$ & $4,65 \mathrm{E}+08$ & $2,97 \mathrm{E}+09$ & $2,59 E+10$ & $7,85 \mathrm{E}+09$ & $1,35 \mathrm{E}+10$ & $2,28 \mathrm{E}+11$ \\
\hline & $\mathbf{F}_{\text {calc }}$ & 0,40 & 0,88 & 3,26 & 4,66 & 16,61 & 1,47 & 2,41 & 13,77 \\
\hline & $t_{\text {calc }}$ & 6,61 & 6,39 & 14,60 & 5,42 & 11,04 & 8,27 & 18,69 & 2,18 \\
\hline \multicolumn{10}{|c|}{ Bisfenol A - Concentração ng.mL ${ }^{-1}$} \\
\hline & [ ] & 100 & 200 & 400 & 800 & 1400 & 2200 & 3000 & 4000 \\
\hline $\begin{array}{c}\text { SEM } \\
\text { matriz }\end{array}$ & $s^{2}$ & $2,52 \mathrm{E}+06$ & $3,10 \mathrm{E}+07$ & $1,56 \mathrm{E}+08$ & $5,50 \mathrm{E}+08$ & $5,69 \mathrm{E}+09$ & $2,17 \mathrm{E}+10$ & $3,18 \mathrm{E}+10$ & $1,17 \mathrm{E}+11$ \\
\hline \multirow{3}{*}{$\begin{array}{c}\text { Matriz } \\
\text { AB }\end{array}$} & $s^{2}$ & $1,14 \mathrm{E}+08$ & $5,82 \mathrm{E}+08$ & $3,95 \mathrm{E}+09$ & $1,28 \mathrm{E}+09$ & $4,47 \mathrm{E}+10$ & $1,40 \mathrm{E}+11$ & $4,49 \mathrm{E}+11$ & $5,11 \mathrm{E}+11$ \\
\hline & $\mathbf{F}_{\text {calc }}$ & 45,21 & 18,78 & 25,33 & 2,33 & 7,85 & 6,46 & 14,14 & 4,38 \\
\hline & $t_{\text {calc }}$ & 4,94 & 7,95 & 1,37 & 21,14 & 0,20 & 6,96 & 0,66 & 4,11 \\
\hline \multicolumn{10}{|c|}{ Benzo[a]pireno - Concentração ng.mL ${ }^{-1}$} \\
\hline & [ ] & 100 & 200 & 400 & 800 & 1400 & 2200 & 3000 & 4000 \\
\hline $\begin{array}{l}\text { SEM } \\
\text { matriz }\end{array}$ & $s^{2}$ & $2,64 \mathrm{E}+07$ & $2,13 \mathrm{E}+08$ & $9,01 \mathrm{E}+08$ & 1,53E+09 & $3,31 E+10$ & $1,40 \mathrm{E}+11$ & $1,25 \mathrm{E}+11$ & $4,48 \mathrm{E}+11$ \\
\hline \multirow{3}{*}{$\begin{array}{c}\text { Matriz } \\
\text { AB }\end{array}$} & $s^{2}$ & $4,22 \mathrm{E}+07$ & $5,89 E+08$ & $2,21 \mathrm{E}+09$ & $3,45 E+09$ & $2,16 \mathrm{E}+10$ & $7,66 \mathrm{E}+10$ & $3,36 \mathrm{E}+11$ & $3,60 \mathrm{E}+11$ \\
\hline & $F_{\text {calc }}$ & 1,60 & 2,76 & 2,46 & 2,25 & 0,65 & 0,55 & 2,68 & 0,80 \\
\hline & $t_{\text {calc }}$ & 16,25 & 7,93 & 6,37 & 10,20 & 22,00 & 13,03 & 21,38 & 18,20 \\
\hline
\end{tabular}


Para que a matriz não apresente efeito sobre a precisão do método, em ambos os testes estatísticos os valores calculados devem ser menores que os valores tabelados. Como se observa nas TAB. 11 e 12 os valores de $\mathrm{F}$ calculados foram superiores ao valor crítico ( $F=4,28$ com 6 graus de liberdade e 95\% de confiança) para praticamente todos os compostos nas oito concentrações consideradas, e em ambas as matrizes, evidenciando que as matrizes interferem no ensaio. Apenas para o composto benzo[a]pireno na amostra de água bruta, os

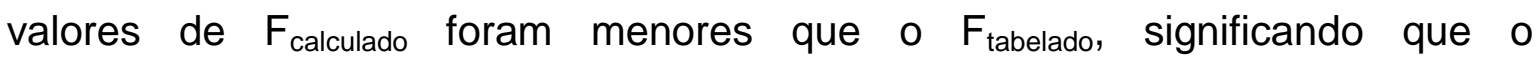
comportamento desse composto nesta matriz é semelhante ao comportamento do mesmo em uma solução somente de solventes. Fato este também observado por Brito (2009).

Assim como no teste $F$, nas duas matrizes consideradas e em quase todas as concentrações avaliadas os valores de $t$ calculados foram maiores que 0 tabelado ( $\mathrm{t}=2,179 \mathrm{com} 12$ graus de liberdade e 95\% de confiança). Estes resultados comprovam que, estatisticamente, as matrizes têm efeito sobre a precisão do método. Portanto, para a quantificação dos analitos deve ser utilizada uma curva analítica preparada na própria amostra, ou em matriz semelhante, uma vez que existirá diferença nos resultados obtidos frente a uma curva preparada somente na solução de solventes.

As representações gráficas da seletividade são demonstradas na FIG. 25, onde se observa comportamento semelhante dos compostos nas diferentes matrizes, com maior inclinação da reta para água tratada, seguida da reta para água bruta e menor inclinação da reta para o ensaio sem matriz. A exceção foi o benzo[a]pireno que apresentou inclinação da reta na matriz de água bruta menor do que a inclinação da reta somente em solvente, com estas se cruzando no ponto referente à concentração de $1,4 \mu \mathrm{g} \cdot \mathrm{mL}^{-1}$. 

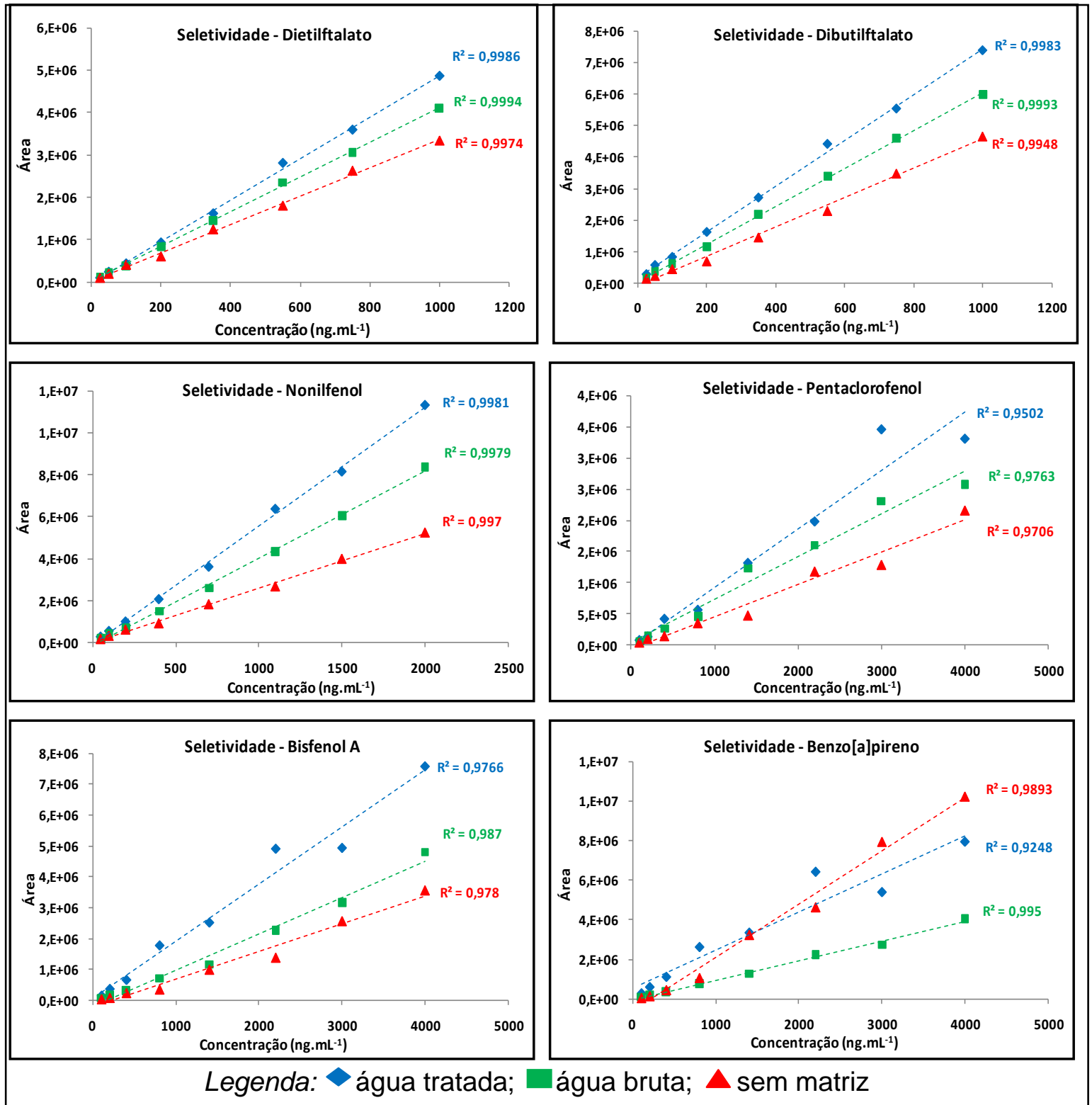

FIGURA 25. Gráficos da seletividade representados pelas retas obtidas nos ensaios com água tratada, água bruta e sem matriz

Pela aplicação dos testes de inclinação e paralelismo e do teste de intercepto é possível comprovar estatisticamente o comportamento das retas visualizado na FIG. 25. Para esses cálculos é utilizado o teste t de Student conforme as equações 7 e 8 apresentadas no item 5.4.1, onde os valores calculados são comparados ao valor de $t$ tabelado. Na TAB. 14 são apresentados os resultados obtidos no ensaio com água tratada, e na TAB. 15 os resultados com a matriz de água bruta. 
TABELA 14. Valores de t calculado obtidos para os testes de inclinação e paralelismo e do intercepto pela aplicação do teste $\mathrm{t}$ Student na matriz de água tratada, considerando os dois conjuntos de amostras com 7 graus de liberdade e $95 \%$ de confiança, onde $\mathbf{2 , 1 7 9}$ é o valor crítico.

\begin{tabular}{ccc}
\hline \multicolumn{3}{c}{$\mathbf{t}_{\text {calculado }}-$ Matriz AT } \\
\hline COMPOSTO & $\begin{array}{c}\text { TESTE DE INCLINAÇÃO E } \\
\text { PARALELISMO }\end{array}$ & TESTE DO INTERCEPTO \\
\hline Dietilftalato & 47,49 & 1,67 \\
Dibutilftalato & 67,71 & 13,04 \\
Nonilfenol & 95,54 & 3,47 \\
Pentaclorofenol & 30,84 & 2,02 \\
Bisfenol A & 51,81 & 6,71 \\
Benzo[a]pireno & 32,48 & 24,29 \\
\hline
\end{tabular}

TABELA 15. Valores de t calculado obtidos para os testes de inclinação e paralelismo e do intercepto pela aplicação do teste t Student na matriz de água bruta, considerando os dois conjuntos de amostra e 7 graus de liberdade e 95\% de confiança, onde 2,179 é o valor crítico.

\begin{tabular}{ccc}
\hline \multicolumn{3}{c}{$\mathbf{t}_{\text {calculado }}-$ Matriz AB } \\
\hline COMPOSTO & $\begin{array}{c}\text { TESTE DE INCLINAÇÃO E } \\
\text { PARALELISMO }\end{array}$ & TESTE DO INTERCEPTO \\
\hline Dietilftalato & 24,54 & 0,02 \\
Dibutilftalato & 37,19 & 6,96 \\
Nonilfenol & 53,74 & 4,16 \\
Pentaclorofenol & 13,83 & 4,15 \\
Bisfenol A & 17,51 & 0,23 \\
Benzo[a]pireno & 79,46 & 13,20 \\
\hline
\end{tabular}

Para que as retas tenham inclinações e interceptos estatisticamente iguais o valor de t calculado deve ser menor que o valor de t crítico $=2,179$ ( $n=8$, 7 graus de liberdade e 95\% de confiança). Como se observa nas TAB. 14 e 15, todos os compostos, e nas duas matrizes avaliadas, apresentaram inclinações diferentes em relação às retas preparadas em solvente, uma vez que obteve-se $t_{\text {calculado }}>t_{\text {tabelado }}$.

O teste do intercepto demonstrou que apenas o dietilftalato apresenta intersecção do eixo y estatisticamente igual na água tratada e na água bruta 
quando comparado à reta obtida na curva analítica sem matriz, com valores de $\mathrm{t}$ calculado de 1,67 e 0,02 nos ensaios de AT e AB, respectivamente. Para o pentaclorofenol os interceptos das curvas com a matriz de água tratada e sem a

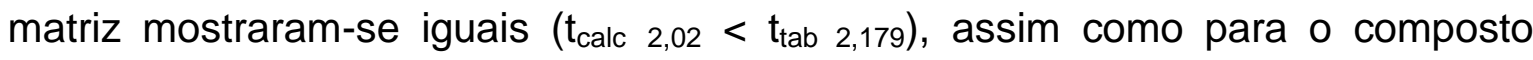
bisfenol $A$ no ensaio com água bruta ( $t_{\text {calc }} 0,23<t_{\text {tab } 2,179}$ ).

\subsubsection{Linearidade e faixa linear de trabalho}

A linearidade do método foi avaliada pelas curvas analíticas, considerando-se o coeficiente de determinação $\left(r^{2}\right)$ obtido pela regressão linear de cada composto nos três ensaios, avaliou-se ainda a análise de resíduos pelo teste $\mathrm{t}$ de Student e o gráficos dos resíduos.

Nas TAB. 16 a 18 são apresentados os intervalos lineares para cada um dos compostos estudados, assim como a equação das retas e os coeficientes de determinação $\left(r^{2}\right)$ obtidos nos ensaios com matriz e sem matriz. As representações gráficas das curvas analíticas para cada um dos compostos nos ensaios com água tratada, água bruta e somente nos solventes podem ser visualizadas nas FIG. 26 a 28. 
TABELA 16. Faixa de trabalho para cada composto, equação da reta e coeficiente de determinação $\left(r^{2}\right)$ obtidos pela adição padrão na matriz de água tratada (AT).

\begin{tabular}{cccc}
\hline \multirow{2}{*}{ COMPOSTO } & $\begin{array}{c}\text { INTERVALO LINEAR } \\
\left(\mu \mathrm{g} \cdot \mathrm{mL}^{-1}\right)\end{array}$ & \multicolumn{2}{c}{ ADIÇÃO NA MATRIZ AT } \\
\cline { 3 - 4 } & $0,025-1,00$ & $\mathrm{y}=4923,1 \mathrm{x}+97209$ & 0,999 \\
\hline Dietilftalato & $0,025-1,00$ & $\mathrm{y}=7 \mathrm{E}+06 \mathrm{x}+842041$ & 0,999 \\
Dibutilftalato & $0,050-2,00$ & $\mathrm{y}=6 \mathrm{E}+06 \mathrm{x}-27558$ & 0,999 \\
Nonilfenol & $0,100-4,00$ & $\mathrm{y}=807046 \mathrm{x}+48236$ & 0,999 \\
Pentaclorofenol & $0,100-3,00$ & $\mathrm{y}=2 \mathrm{E}+06 \mathrm{x}+94946$ & 0,999 \\
Bisfenol $A$ & $0,100-3,00$ & $\mathrm{y}=2 \mathrm{E}+06 \mathrm{x}+256743$ & 0,999 \\
Benzo[a]pireno & & &
\end{tabular}
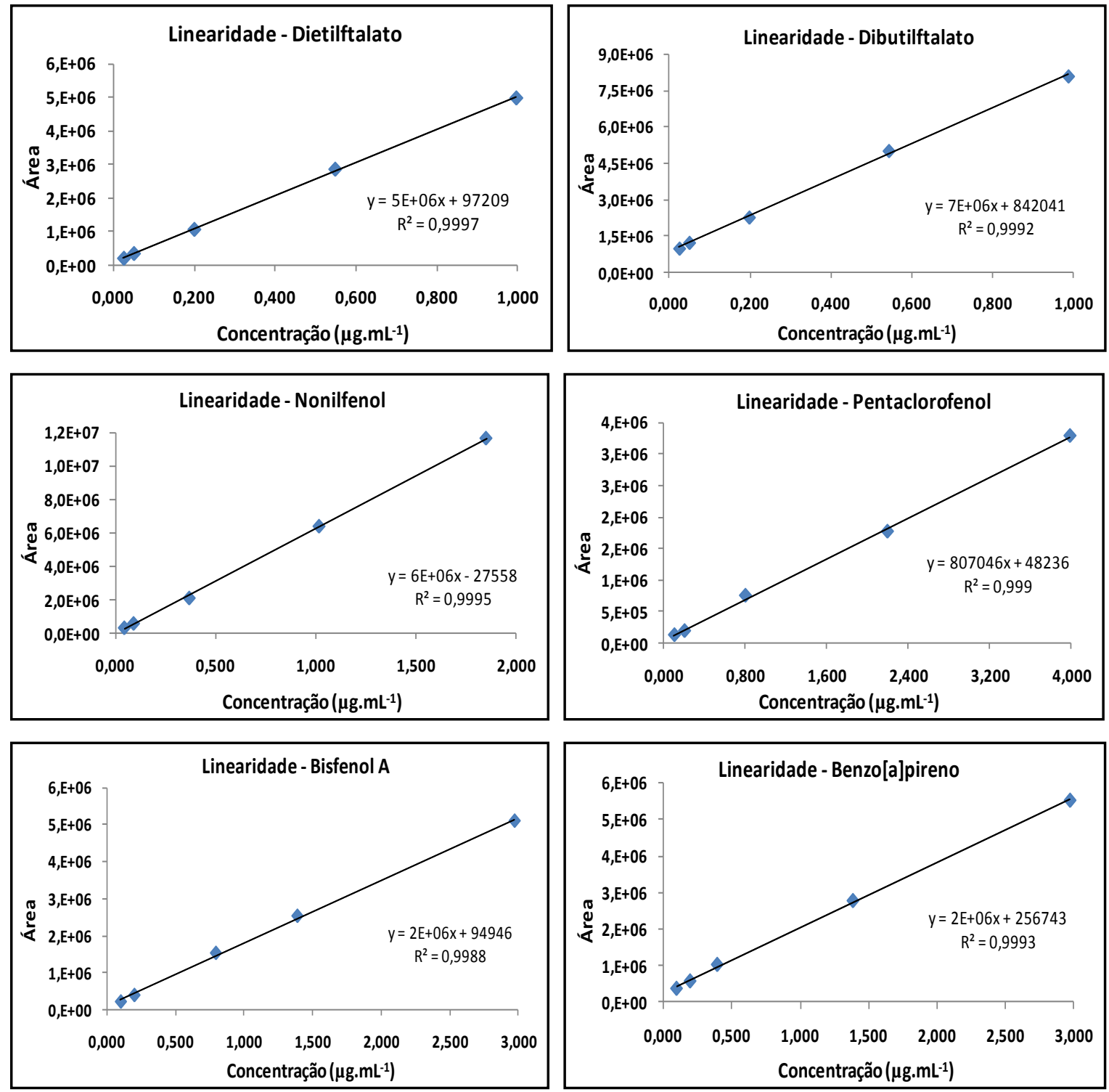

FIGURA 26. Representação gráfica da linearidade para os seis xenoestrógenos estudados na matriz de água tratada. 
TABELA 17. Faixa de trabalho para cada composto, equação da reta e coeficiente de determinação $\left(r^{2}\right)$ obtidos pela adição padrão na matriz de água bruta $(A B)$.

\begin{tabular}{cccc}
\hline \multirow{2}{*}{ Composto } & $\begin{array}{c}\text { INTERVALO LINEAR } \\
\left(\mu \mathrm{g} \cdot \mathrm{mL}^{-1}\right)\end{array}$ & \multicolumn{2}{c}{ ADIÇÃO NA MATRIz AB } \\
\cline { 3 - 4 } & $0,025-1,00$ & $\mathrm{y}=4 \mathrm{E}+06 \mathrm{x}+32889$ & 0,999 \\
\hline Dietilftalato & $0,025-1,00$ & $\mathrm{y}=6 \mathrm{E}+06 \mathrm{x}+228363$ & 0,999 \\
Dibutilftalato & $0,050-2,00$ & $\mathrm{y}=5 \mathrm{E}+06 \mathrm{x}+10617$ & 0,999 \\
Nonilfenol & $0,100-4,00$ & $\mathrm{y}=629515 \mathrm{x}+29077$ & 0,999 \\
Pentaclorofenol & $0,100-3,00$ & $\mathrm{y}=921985 \mathrm{x}-2179,2$ & 0,999 \\
Bisfenol $A$ & $0,100-3,00$ & $\mathrm{y}=777057 \mathrm{x}+42376$ & 0,999 \\
Benzo[a]pireno & & &
\end{tabular}
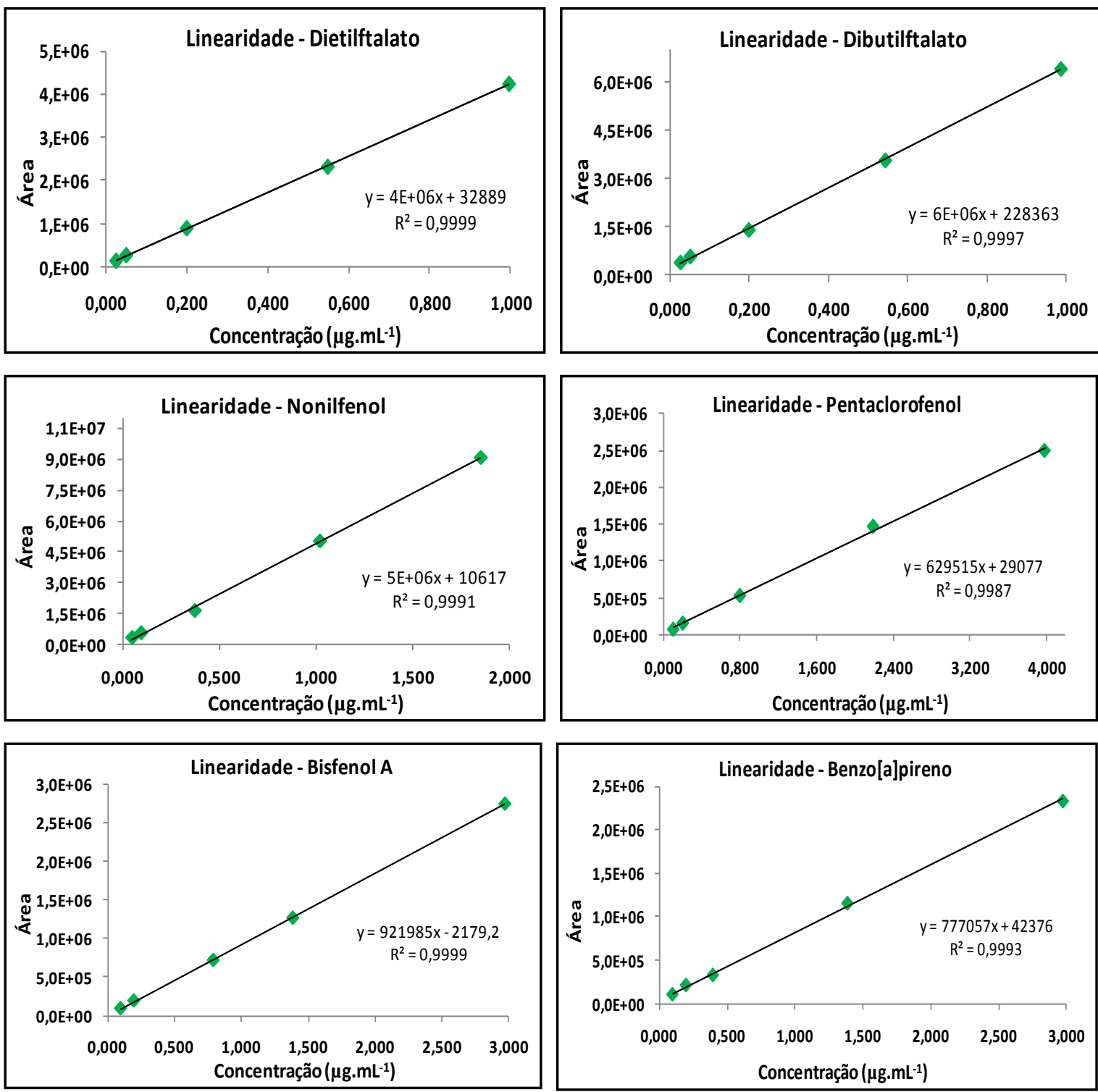

FIGURA 27. Representação gráfica da linearidade para os seis xenoestrógenos estudados na matriz de água bruta. 
TABELA 18. Faixa de trabalho para cada composto, equação da reta e coeficiente de determinação $\left(r^{2}\right)$ obtidos pela adição padrão somente na solução de solventes

\begin{tabular}{cccc}
\hline \multirow{2}{*}{ COMPOSTO } & $\begin{array}{c}\text { INTERVALO LINEAR } \\
\left(\mu \mathrm{g} \cdot \mathrm{mL}^{-1}\right)\end{array}$ & \multicolumn{2}{c}{ ADIÇÃO NOS SolvenTES } \\
\cline { 3 - 4 } & $0,025-1,00$ & $\mathrm{y}=3 \mathrm{E}+06 \mathrm{x}-11134$ & 0,999 \\
\hline Dietilftalato & $0,025-1,00$ & $\mathrm{y}=5 \mathrm{E}+06 \mathrm{x}-88238$ & 0,996 \\
Dibutilftalato & $0,050-2,00$ & $\mathrm{y}=3 \mathrm{E}+06 \mathrm{x}-24167$ & 0,998 \\
Nonilfenol & $0,100-4,00$ & $\mathrm{y}=575892 \mathrm{x}-31253$ & 0,999 \\
Pentaclorofenol & $0,100-3,00$ & $\mathrm{y}=919465 \mathrm{x}-168056$ & 0,985 \\
Bisfenol $A$ & $0,100-3,00$ & $\mathrm{y}=3 \mathrm{E}+06 \mathrm{x}-572640$ & 0,989 \\
Benzo[a]pireno & & &
\end{tabular}
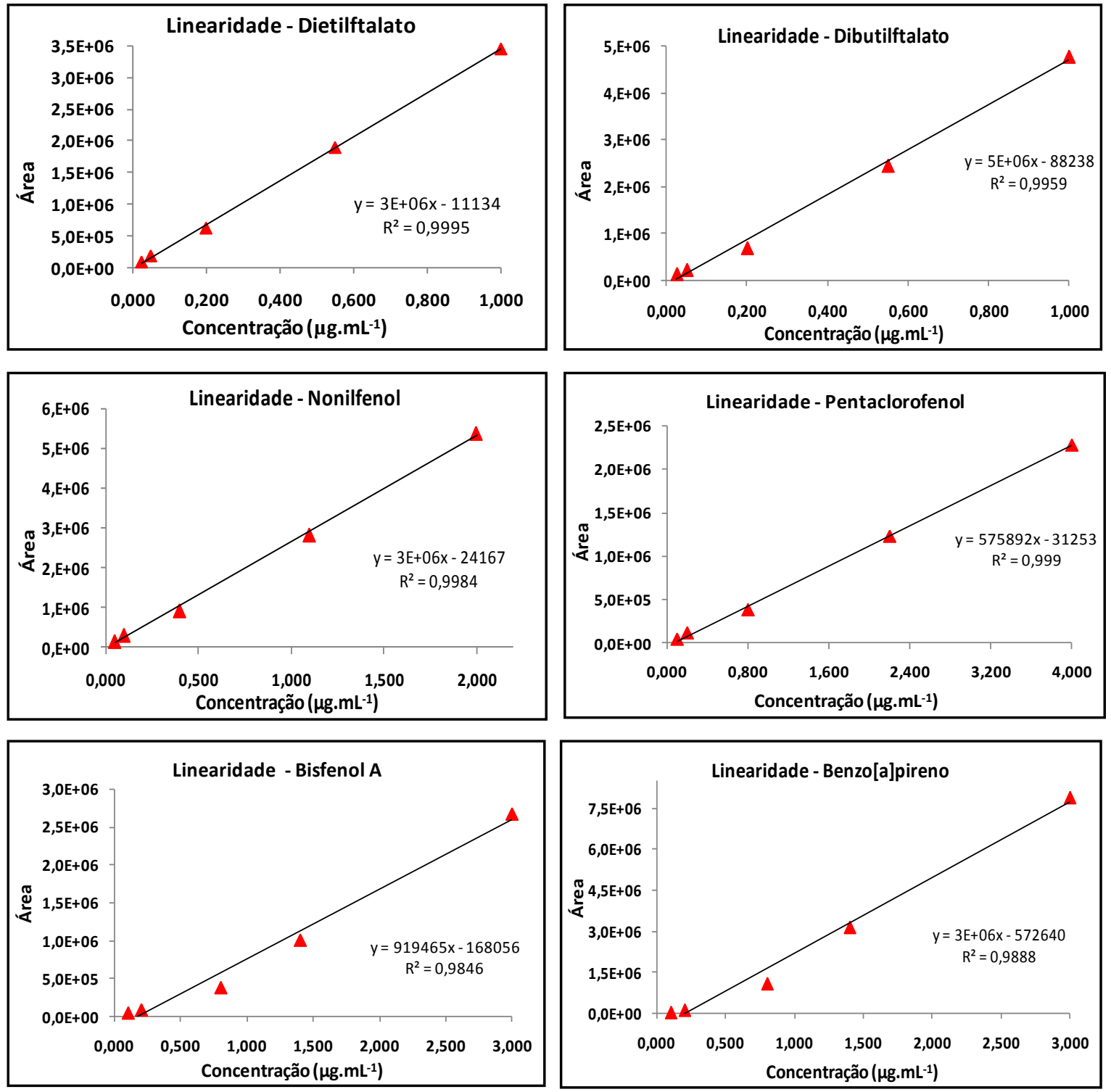

FIGURA 28. Representação gráfica da linearidade para os seis xenoestrógenos estudados no ensaio sem matriz. 
Como pode ser observado nas TAB. 16 a 18 e FIG. 26 a 28 anteriormente mencionadas, nas faixas de concentração avaliadas as retas obtidas demonstraram-se lineares, com coeficientes de determinação acima de 0,99 nas matrizes de água tratada e água bruta.

A diferença entre o valor medido e o valor calculado (análise dos resíduos) foi realizada pelo teste t de Student, conforme equação 10 do item 5.4.2, onde os valores de $t$ calculados acima do valor crítico $t_{(8,95 \%)}=2,365$ indicam que o ponto não pode ser considerado como pertencente à reta de regressão. Os resultados obtidos para t calculado nos ensaios com e sem matriz são apresentados nas TAB. 18 a 20.

TABELA 19. Valores de $t$ calculado obtidos pelo teste $t$ Student para a verificação do desvio da linearidade de cada ponto da curva para os seis compostos estudados na matriz de água tratada, onde 0 valor de $t_{\text {tab }}=2,365$ considerando 7 graus de liberdade (n-1) e 95\% de confiança.

\begin{tabular}{|c|c|c|c|c|c|c|c|c|c|}
\hline \multirow{2}{*}{ DIETILFTALATO } & $\mathrm{ng} \cdot \mathrm{mL}^{-1}$ & 25 & 50 & 100 & 200 & 350 & 550 & 750 & 1000 \\
\hline & $t_{\text {calc }}$ & 0,202 & 0,651 & 0,617 & 0,357 & 3,634 & 5,711 & 3,014 & 0,344 \\
\hline \multirow{2}{*}{ DIBUTILFTALATO } & $\mathrm{ng} \cdot \mathrm{mL}^{-1}$ & 25 & 50 & 100 & 200 & 350 & 550 & 750 & 1000 \\
\hline & $t_{\text {calc }}$ & 0,732 & 0,959 & 1,260 & 0,388 & 1,818 & 6,031 & 3,622 & 0,055 \\
\hline \multirow{2}{*}{ NONILFENOL } & $\mathrm{ng} \cdot \mathrm{mL}^{-1}$ & 50 & 100 & 200 & 400 & 700 & 1100 & 1500 & 2000 \\
\hline & $t_{\text {calc }}$ & 1,156 & 1,058 & 0,338 & 0,398 & 3,996 & 4,496 & 3,740 & 1,763 \\
\hline \multirow{2}{*}{ PENTACLOROFENOL } & $\mathrm{ng} \cdot \mathrm{mL}^{-1}$ & 100 & 200 & 400 & 800 & 1400 & 2200 & 3000 & 4000 \\
\hline & $t_{\text {calc }}$ & 0,345 & 0,634 & 0,374 & 0,987 & 1,031 & 1,747 & 6,032 & 3,723 \\
\hline \multirow{2}{*}{ BISFENOL A } & $\mathrm{ng} \cdot \mathrm{mL}^{-1}$ & 100 & 200 & 400 & 800 & 1400 & 2200 & 3000 & 4000 \\
\hline & $t_{\text {calc }}$ & 0,214 & 0,039 & 0,692 & 0,682 & 1,570 & 5,537 & 4,593 & 0,889 \\
\hline \multirow{2}{*}{ BENZO[A]PIRENO } & $\mathrm{ng} \cdot \mathrm{mL}^{-1}$ & 100 & 200 & 400 & 800 & 1400 & 2200 & 3000 & 4000 \\
\hline & $t_{\text {calc }}$ & 1,353 & 0,922 & 0,632 & 1,267 & 0,247 & 6,191 & 3,504 & 0,801 \\
\hline
\end{tabular}


TABELA 20. Valores de $t$ calculado obtidos pelo teste t Student para a verificação do desvio da linearidade de cada ponto da curva para os seis compostos estudados na matriz de água bruta, onde 0 valor de $t_{\text {tab }}=2,365$ considerando 7 graus de liberdade (n-1) e 95\% de confiança.

\begin{tabular}{|c|c|c|c|c|c|c|c|c|c|}
\hline \multirow{2}{*}{ DIETILFTALATO } & $\mathrm{ng} \cdot \mathrm{mL}^{-1}$ & 25 & 50 & 100 & 200 & 350 & 550 & 750 & 1000 \\
\hline & $t_{\text {calc }}$ & 0,165 & 0,293 & 0,713 & 0,638 & 1,569 & 5,064 & 4,981 & 1,433 \\
\hline \multirow{2}{*}{ DIBUTILFTALATO } & $\mathrm{ng} \cdot \mathrm{mL}^{-1}$ & 25 & 50 & 100 & 200 & 350 & 550 & 750 & 1000 \\
\hline & $t_{\text {calc }}$ & 0,064 & 1,043 & 0,392 & 0,895 & 1,922 & 5,316 & 4,509 & 1,295 \\
\hline \multirow{2}{*}{ NONILFENOL } & $\mathrm{ng} \cdot \mathrm{mL}^{-1}$ & 50 & 100 & 200 & 400 & 700 & 1100 & 1500 & 2000 \\
\hline & $t_{\text {calc }}$ & 1,451 & 1,631 & 0,045 & 0,009 & 4,066 & 1,616 & 4,325 & 3,658 \\
\hline \multirow{2}{*}{ PENTACLOROFENOL } & $\mathrm{ng} \cdot \mathrm{mL}^{-1}$ & 100 & 200 & 400 & 800 & 1400 & 2200 & 3000 & 4000 \\
\hline & $t_{\text {calc }}$ & 0,922 & 0,687 & 0,611 & 2,200 & 4,373 & 0,123 & 3,856 & 3,932 \\
\hline \multirow{2}{*}{ BISFENOL A } & $\mathrm{ng} \cdot \mathrm{mL}^{-1}$ & 100 & 200 & 400 & 800 & 1400 & 2200 & 3000 & 4000 \\
\hline & $t_{\text {calc }}$ & 1,475 & 1,328 & 0,316 & 0,015 & 3,756 & 1,313 & 4,582 & 3,891 \\
\hline \multirow{2}{*}{ BENZO[A]PIRENO } & $\mathrm{ng} \cdot \mathrm{mL}^{-1}$ & 100 & 200 & 400 & 800 & 1400 & 2200 & 3000 & 4000 \\
\hline & $t_{\text {calc }}$ & 0,334 & 0,715 & 0,462 & 0,656 & 1,737 & 3,200 & 5,701 & 2,995 \\
\hline
\end{tabular}

TABELA 21. Valores de $t$ calculado obtidos pelo teste $t$ Student para a verificação do desvio da linearidade de cada ponto da curva para os seis compostos estudados no ensaio sem matriz, onde o valor de $t_{t a b}=2,365$ considerando 7 graus de liberdade (n-1) e 95\% de confiança.

\begin{tabular}{cccccccccc}
\hline \multirow{2}{*}{ Dietilftalato } & $\mathrm{ng} \cdot \mathrm{mL}^{-1}$ & 25 & 50 & 100 & 200 & 350 & 550 & 750 & 1000 \\
& $\mathbf{t}_{\text {calc }}$ & $\mathbf{0 , 1 0 3}$ & $\mathbf{0 , 4 7 3}$ & $\mathbf{2 , 7 4 0}$ & $\mathbf{4 , 0 6 9}$ & $\mathbf{1 , 0 8 1}$ & $\mathbf{2 , 7 4 8}$ & $\mathbf{3 , 9 0 0}$ & $\mathbf{1 , 2 7 3}$ \\
\hline \multirow{2}{*}{ Dibutilftalato } & $\mathrm{ng} \cdot \mathrm{mL}^{-1}$ & 25 & 50 & 100 & 200 & 350 & 550 & 750 & 1000 \\
& $\mathbf{t}_{\text {calc }}$ & $\mathbf{2 , 6 0 2}$ & $\mathbf{1 , 9 2 7}$ & $\mathbf{1 , 5 9 1}$ & $\mathbf{3 , 4 7 0}$ & $\mathbf{2 , 4 0 8}$ & $\mathbf{4 , 0 0 8}$ & $\mathbf{1 , 3 7 9}$ & $\mathbf{2 , 3 8 6}$ \\
\hline \hline \multirow{2}{*}{ Nonilfenol } & $\mathrm{ng} \cdot \mathrm{mL}^{-1}$ & 50 & 100 & 200 & 400 & 700 & 1100 & 1500 & 2000 \\
& $\mathbf{t}_{\text {calc }}$ & $\mathbf{1 , 0 2 4}$ & $\mathbf{1 , 7 5 0}$ & $\mathbf{2 , 8 0 8}$ & $\mathbf{3 , 2 6 0}$ & $\mathbf{1 , 3 8 9}$ & $\mathbf{4 , 6 2 9}$ & $\mathbf{1 , 6 2 4}$ & $\mathbf{2 , 0 7 2}$ \\
\hline \hline \multirow{2}{*}{ Pentaclorofenol } & $\mathrm{ng} \cdot \mathrm{mL}^{-1}$ & 100 & 200 & 400 & 800 & 1400 & 2200 & 3000 & 4000 \\
& $\mathbf{t}_{\text {calc }}$ & $\mathbf{1 , 2 8 5}$ & $\mathbf{1 , 4 6 1}$ & $\mathbf{0 , 0 3 2}$ & $\mathbf{0 , 0 2 5}$ & $\mathbf{3 , 7 8 5}$ & $\mathbf{2 , 5 1 1}$ & $\mathbf{5 , 0 4 7}$ & $\mathbf{3 , 6 3 2}$ \\
\hline \hline \multirow{2}{*}{ Bisfenol A } & $\mathrm{ng} \cdot \mathrm{mL}^{-1}$ & 100 & 200 & 400 & 800 & 1400 & 2200 & 3000 & 4000 \\
& $\mathbf{t}_{\text {calc }}$ & $\mathbf{2 , 3 6 4}$ & $\mathbf{1 , 6 7 7}$ & $\mathbf{1 , 3 4 4}$ & $\mathbf{2 , 2 9 3}$ & $\mathbf{1 , 5 1 6}$ & $\mathbf{5 , 5 6 0}$ & $\mathbf{0 , 8 5 3}$ & $\mathbf{3 , 1 3 0}$ \\
\hline \hline \multirow{2}{*}{ Benzo[a]pireno } & $\mathrm{ng} \cdot \mathrm{mL}^{-1}$ & 100 & 200 & 400 & 800 & 1400 & 2200 & 3000 & $\mathbf{4 0 0 0}$ \\
& $\mathbf{t}_{\text {calc }}$ & $\mathbf{2 , 6 8 6}$ & $\mathbf{1 , 4 8 5}$ & $\mathbf{0 , 0 5 9}$ & $\mathbf{3 , 2 1 4}$ & $\mathbf{0 , 1 9 4}$ & $\mathbf{4 , 4 5 8}$ & $\mathbf{2 , 9 0 4}$ & $\mathbf{0 , 8 4 9}$ \\
\hline
\end{tabular}


Os resultados apresentados nas TAB. 19 a 21 demonstram que vários pontos estão acima do valor crítico de 2,365, significando que os mesmos não poderiam ser considerados como pertencentes à reta de regressão da curva analítica. Nota-se ainda que o comportamento foi similar nos ensaios com matriz, onde nos pontos de concentrações mais elevadas os valores ficaram acima do especificado. Porém avaliando-se cada resultado individualmente, observa-se que alguns estão muito próximos do valor ideal, sendo possível considerar que estes pontos podem ser utilizados na quantificação dos analitos. Convém citar que os dados não foram tratados para se obter um melhor resultado, pois o intuito deste processo de validação é estabelecer o uso do método em condições básicas. Além disso, a recomendação do INMETRO (2003) é de que o coeficiente de correlação linear ( $r$ ) seja >0,90 para realizar-se a quantificação, condição esta que foi atingida, tendo todos os compostos nas duas matrizes valores de $r^{2}>0,99$.

A linearidade foi avaliada também pelos gráficos de resíduos. Nas FIG. 29 a 34 são apresentados os gráficos de distribuição espacial dos resíduos absolutos em função das concentrações e a distribuição dos resíduos em função da probabilidade normalizada nos ensaios com as amostras de água tratada, água bruta e somente nos solventes, respectivamente.
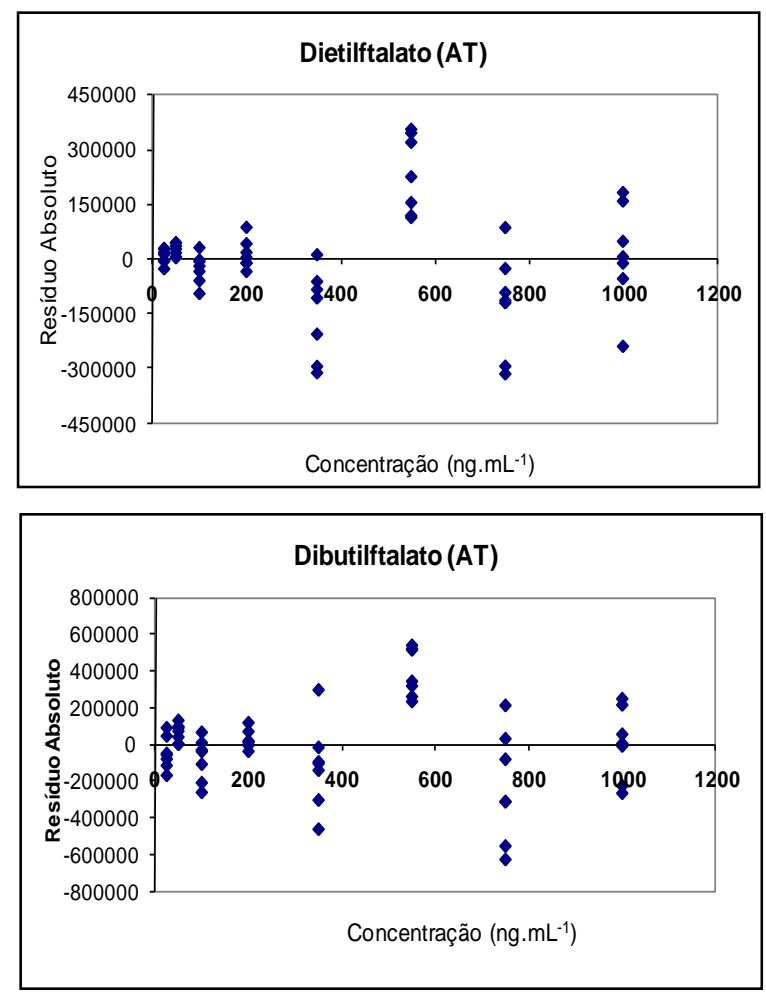

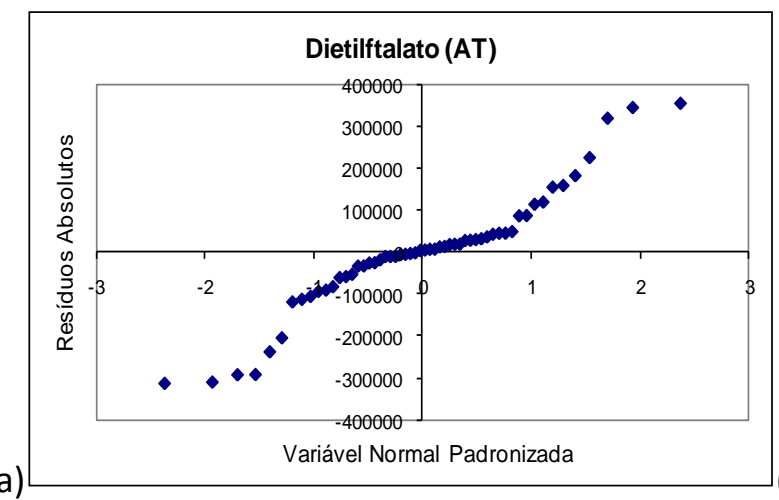

(b)

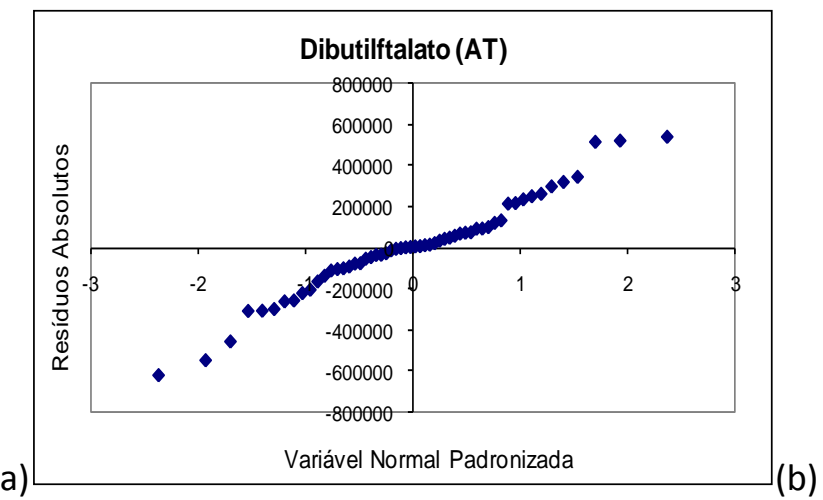

FIGURA 29. Gráficos dos resíduos absolutos (a) e normalizados (b) para os compostos dietilftalato e dibutilftalato no ensaio com matriz de água tratada (AT). 

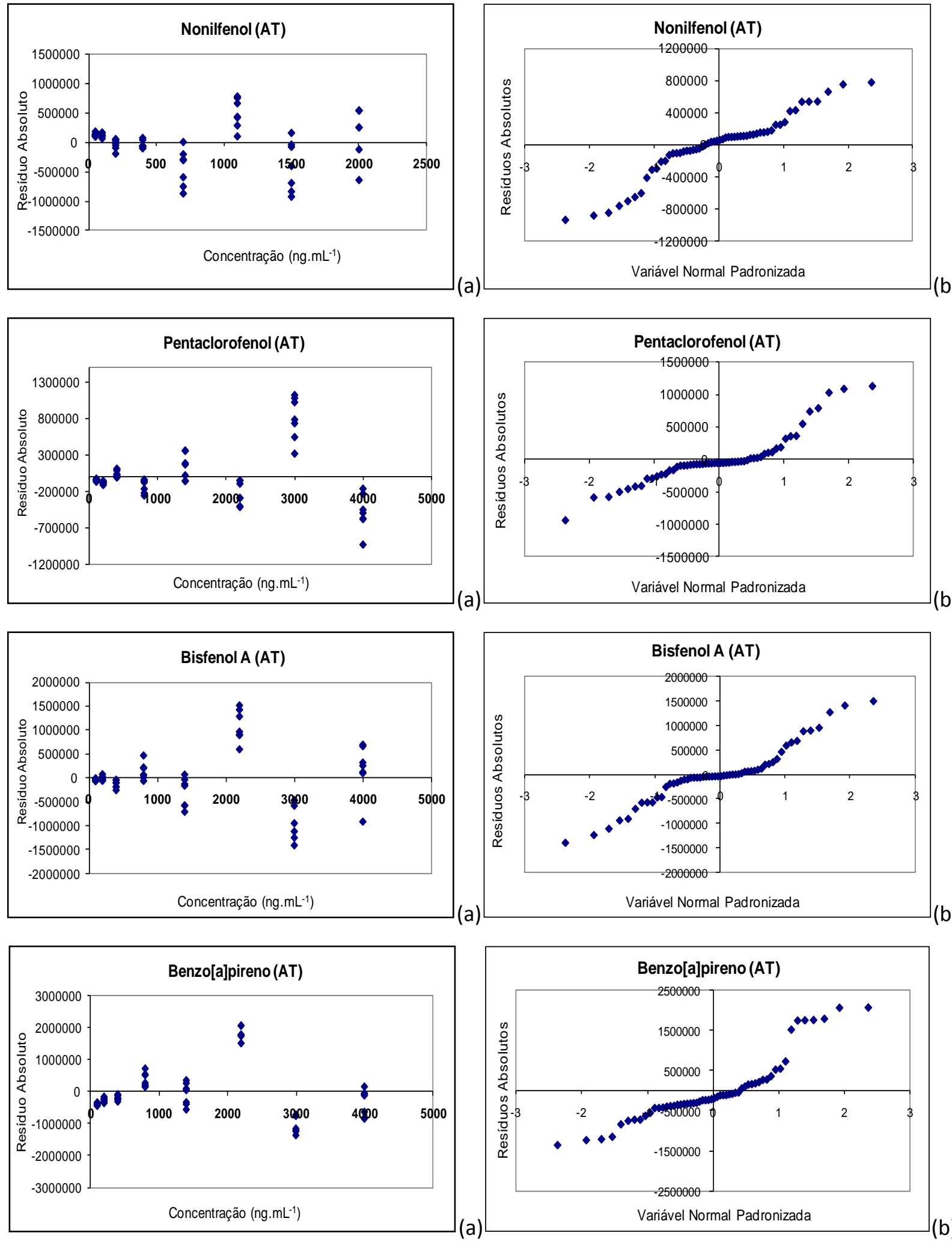

FIGURA 30. Gráficos dos resíduos absolutos (a) e normalizados (b) para os compostos nonilfenol, pentaclorofenol, bisfenol A e benzo[a]pireno no ensaio com matriz de água tratada (AT). 

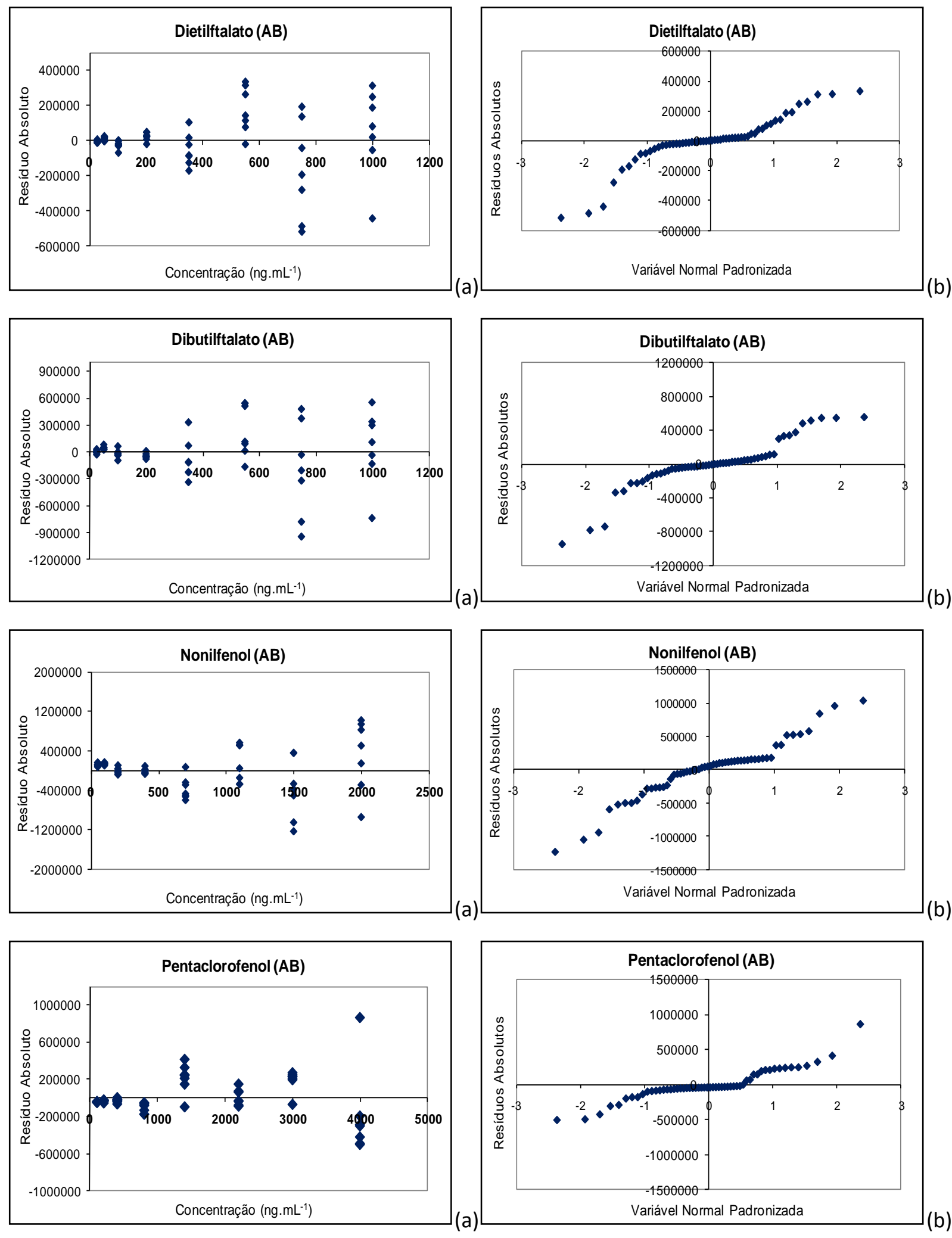

FIGURA 31. Gráficos dos resíduos absolutos (a) e normalizados (b) para os compostos dietilftalato, dibutilftalato, nonilfenol e pentaclorofenol no ensaio com matriz de água bruta $(A B)$. 

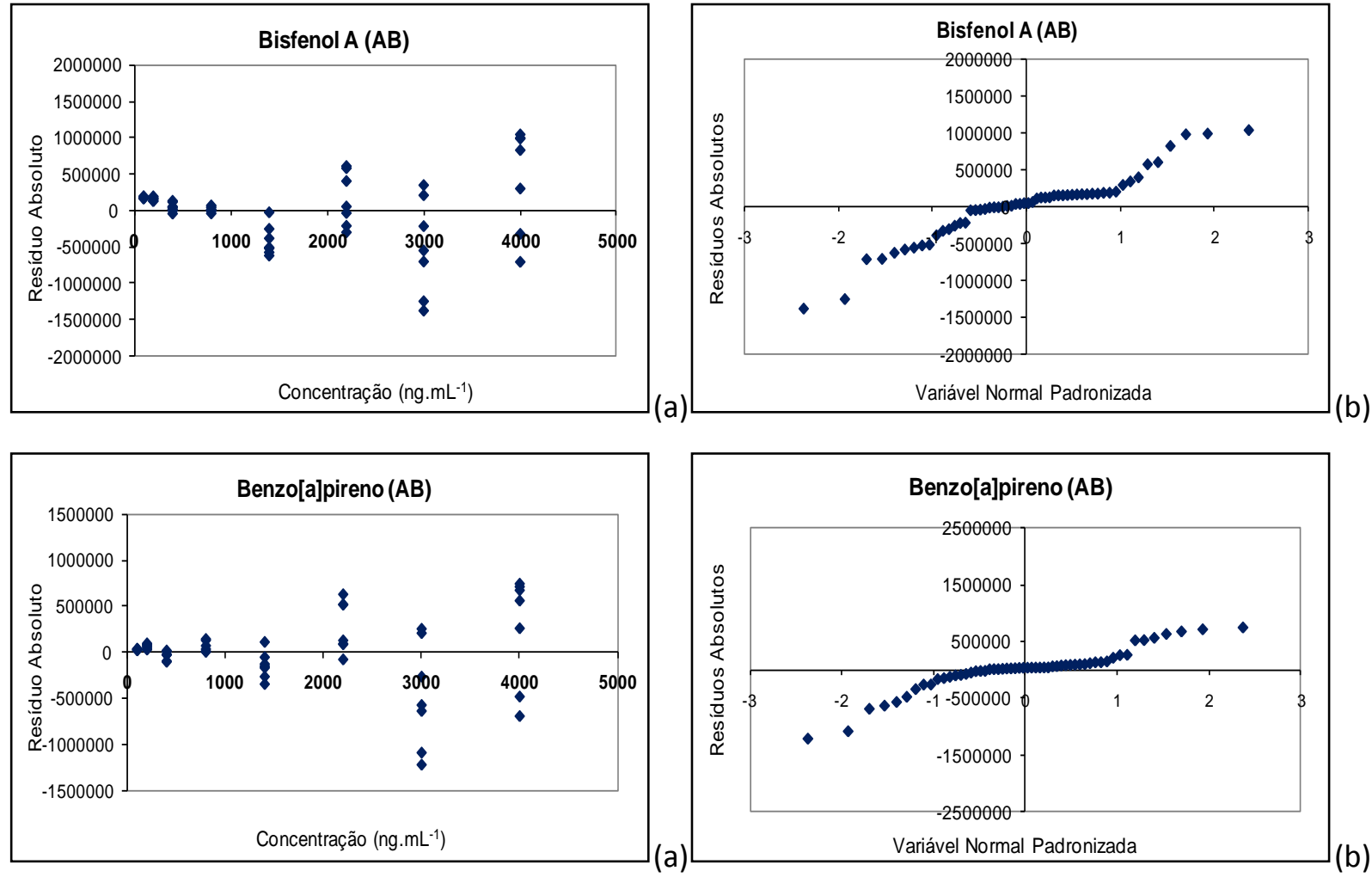

FIGURA 32. Gráficos dos resíduos absolutos (a) e normalizados (b) para os compostos bisfenol $A$ e benzo[a]pireno no ensaio com matriz de água bruta $(A B)$.
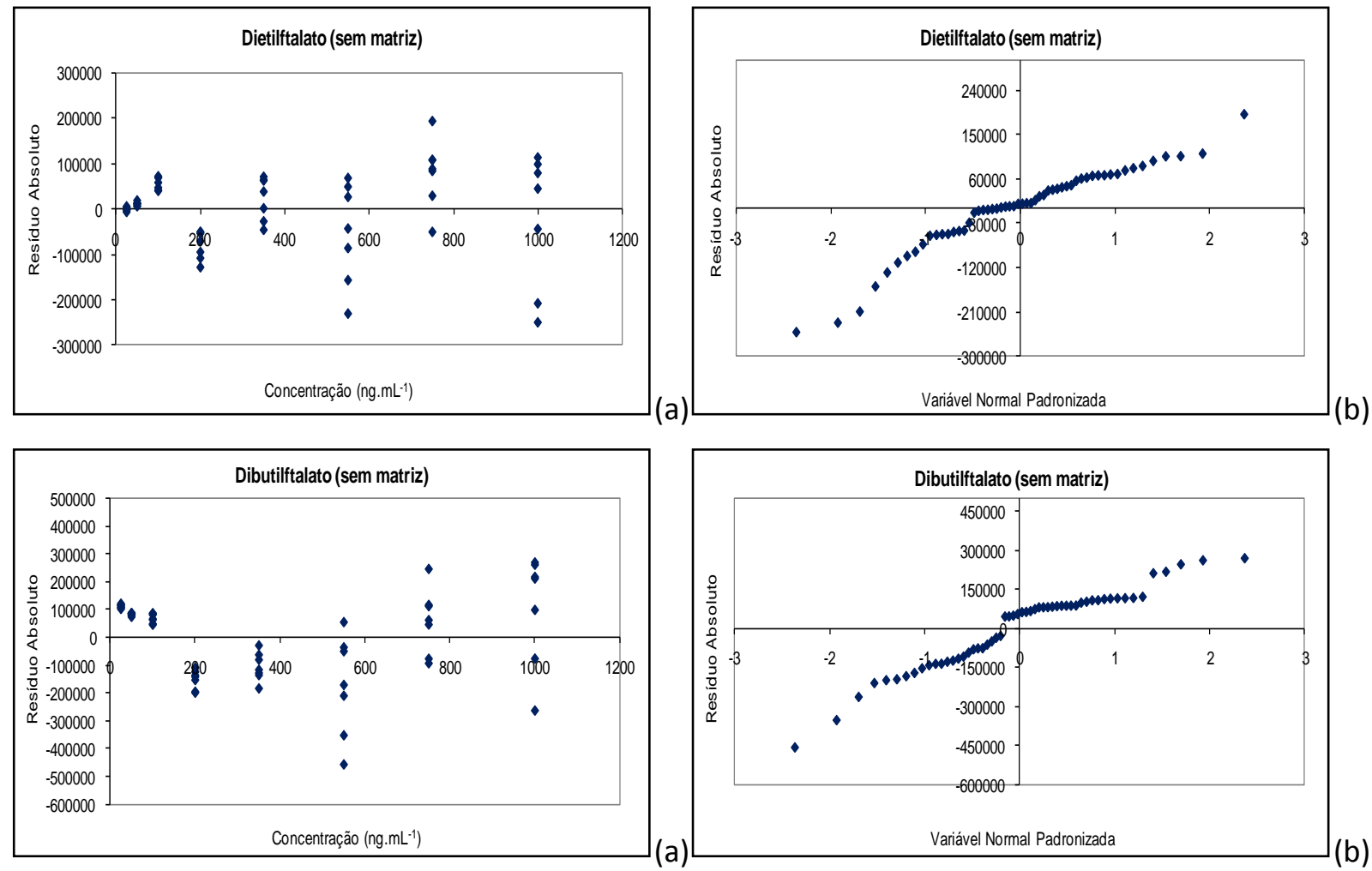

FIGURA 33. Gráficos dos resíduos absolutos (a) e normalizados (b) para os compostos dietilftalato e dibutilftalato no ensaio sem matriz. 

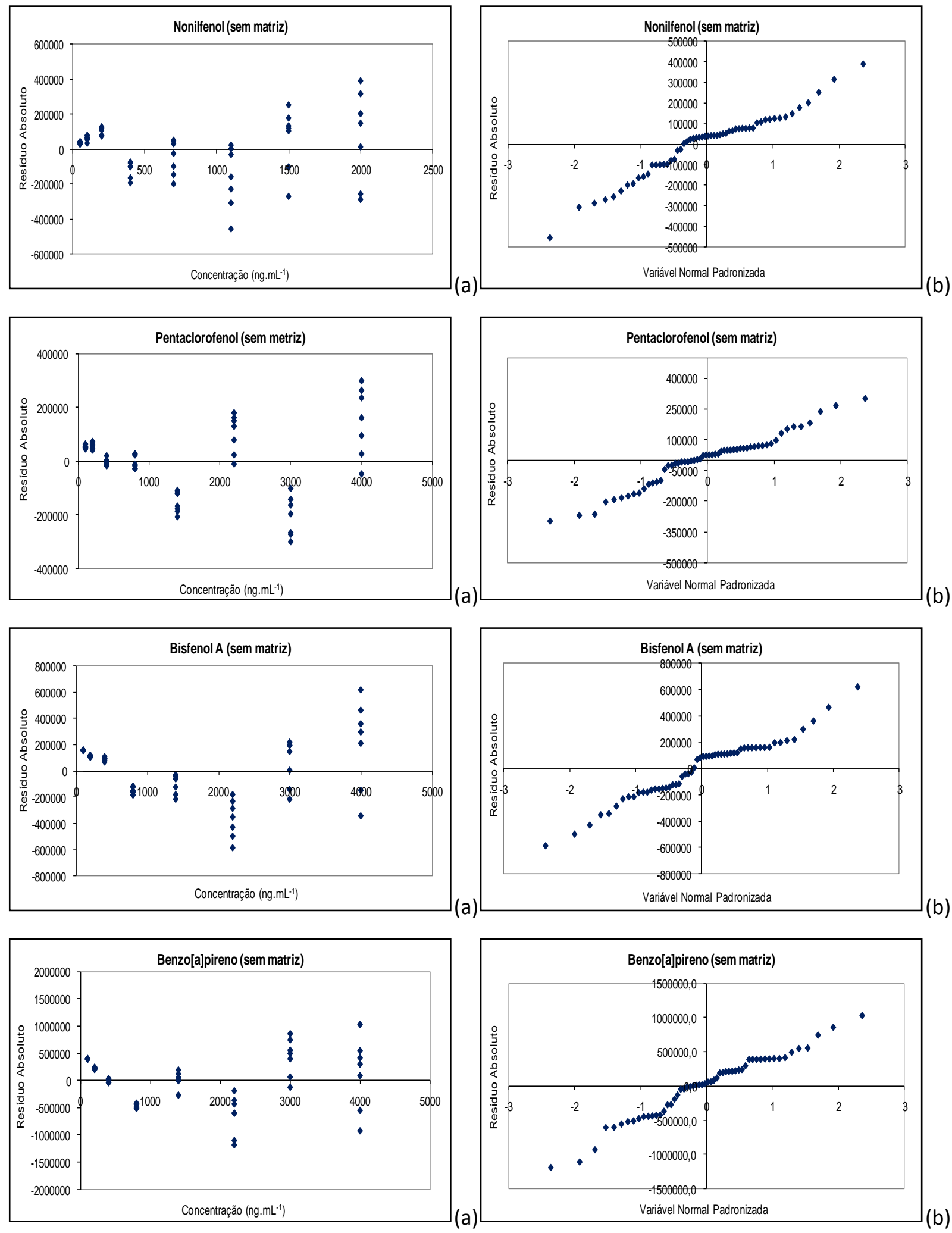

FIGURA 34. Gráficos dos resíduos absolutos (a) e normalizados (b) para os compostos nonilfenol, pentaclorofenol, bisfenol A e benzo[a]pireno no ensaio sem matriz. 
Quando se observam os gráficos da distribuição dos resíduos absolutos versus a concentração (FIG. 29 a 34a) é possível perceber uma maior flutuação entre as replicatas, seja positiva ou negativa, nas concentrações mais altas. No entanto, quando se analisam os gráficos dos resíduos pela probabilidade normal (FIG. 29 a 34b) nota-se que a maioria dos pontos está distribuída no intervalo de probabilidade de -2 a +2 , ou seja, dentro de \pm 2 desvios padrão, com 95\% de confiança. Observa-se ainda, que a distribuição se aproxima de uma reta, sem grandes tendências que depreciem o comportamento linear.

Por meio da análise de variâncias (tabela ANOVA) calcula-se a porcentagem de variação explicada e a porcentagem máxima de variação explicável $\left(r^{2}\right)$. A partir do teste $F$ de regressão verificar-se se o modelo de regressão adotado é significativo, ou seja, se o modelo linear, representado pela equação da reta, se ajusta ao conjunto de dados obtidos com $95 \%$ de confiança. Enquanto o teste $\mathrm{F}$ de ajuste analisa o quanto esse modelo se ajusta ao conjunto de dados obtidos, considerando o mesmo limite de confiança. Os resultados simplificados destes testes nas matrizes de água tratada e bruta são expressos nas TAB. 22 e 23.

TABELA 22. Resultados resumidos da análise de variância (ANOVA) para os seis compostos estudados no ensaio com matriz de água tratada.

\begin{tabular}{|c|c|c|c|c|}
\hline \multirow{3}{*}{ COMPOSTO } & \multicolumn{2}{|c|}{$\mathrm{F}_{\text {CALCULADO }}$ na MATRIZ AT } & \multirow{3}{*}{$\begin{array}{c}\% \text { DE } \\
\text { VARIAÇÃO } \\
\text { EXPLICADA }\end{array}$} & \multirow{3}{*}{$\begin{array}{l}\text { \% MÁXIMA DE } \\
\text { VARIAÇÃO } \\
\text { EXPLICÁVEL }\end{array}$} \\
\hline & REGRESSÃO & AJUSTE & & \\
\hline & $F_{\operatorname{tab}(2,13,95 \%)}=3,81$ & $F_{\operatorname{tab}(5,8,95 \%)}=3,69$ & & \\
\hline Dietilftalato & 1056,22 & 4,87 & 99,4 & 99,9 \\
\hline Dibutilftalato & 896,73 & 4,18 & 99,3 & 99,8 \\
\hline Nonilfenol & 820,57 & 5,30 & 99,2 & 99,8 \\
\hline Pentaclorofenol & 73,06 & 12,31 & 91,8 & 99,1 \\
\hline Bisfenol A & 126,61 & 9,43 & 95,1 & 99,3 \\
\hline Benzo[a]pireno & 68,60 & 41,75 & 91,4 & 99,7 \\
\hline
\end{tabular}


TABELA 23. Resultados resumidos da análise de variância (ANOVA) para os seis compostos estudados no ensaio com matriz de água bruta.

\begin{tabular}{|c|c|c|c|c|}
\hline \multirow{3}{*}{ COMPOSTO } & \multicolumn{2}{|c|}{$F_{\text {CALCULADO }}$ na MATRIZ AB } & \multirow{3}{*}{$\begin{array}{c}\% \text { DE } \\
\text { VARIAÇÃO } \\
\text { EXPLICADA }\end{array}$} & \multirow{3}{*}{$\begin{array}{l}\text { \% MÁXIMA DE } \\
\text { VARIAÇÃO } \\
\text { EXPLICÁVEL }\end{array}$} \\
\hline & REGRESSÃO & AJUSTE & & \\
\hline & $F_{\operatorname{tab}(2,13,95 \%)}=3,81$ & $F_{\text {tab }(5,8,95 \%)}=3,69$ & & \\
\hline Dietilftalato & 553,63 & 1,15 & 98,8 & 99,3 \\
\hline Dibutilftalato & 432,98 & 0,58 & 98,5 & 98,9 \\
\hline Nonilfenol & 334,62 & 0,99 & 98,1 & 98,8 \\
\hline Pentaclorofenol & 277,63 & 4,70 & 97,7 & 99,4 \\
\hline Bisfenol A & 79,57 & 1,52 & 92,5 & 96,1 \\
\hline Benzo[a]pireno & 90,94 & 1,34 & 93,3 & 96,4 \\
\hline
\end{tabular}

Os resultados obtidos pelo teste de regressão, tanto na matriz de água tratada quanto na água bruta, demonstram que a regressão aplicada é significativa, ou seja, que a equação da reta é adequada para os pares de pontos considerados, uma vez que os valores de $\mathrm{F}$ calculados foram superiores ao valor de $F$ tabelado $\left(F_{\text {tab }}=3,81\right)$.

Quando considerados os resultados do teste de ajuste, observa-se que houve falta de ajuste no ensaio com água tratada para todos os compostos, com valores de $t_{\text {calculado }}>t_{\text {tabelado }}\left(t_{\text {tab }}=3,39\right.$ ), significando que há dispersão entre os pontos ou que, apesar da equação da reta ser adequada, existem pontos fora. Todavia, no ensaio com a amostra de água bruta, apenas o composto pentaclorofenol apresentou valor calculado acima do tabelado, indicando que nesta matriz não é observada falta de ajuste para os demais analitos.

Pela avaliação das porcentagens de variação é possível constatar que as porcentagens de variação explicadas estão próximas às porcentagens máximas explicáveis, com valores acima de $90 \%$ para todos os compostos em ambas as matrizes, evidenciando que as variações foram explicadas satisfatoriamente pelos modelos lineares adotados e que os mesmos se ajustam ao conjunto de dados. Sendo possível dessa forma estabelecer que a falta de ajuste observada na matriz de água tradada não é significativa. 
Nos gráficos da FIG. 35 são apresentadas as faixas de intervalos de confiança para cada composto nas faixas de trabalho consideradas. Dentro desta faixa, os resultados são estatisticamente aceitáveis. Como pode ser observado para os compostos dietilftalato, dibutilftalato e nonilfenol o intervalo de confiança é estreito em praticamente toda a faixa de trabalho. Para os demais compostos, perde-se um pouco a confiança no resultado tanto no limite inferior quanto superior da curva analítica, devendo-se, portanto estabelecer uma curva mais próxima a esses limites quando for necessária a quantificação nesses intervalos.
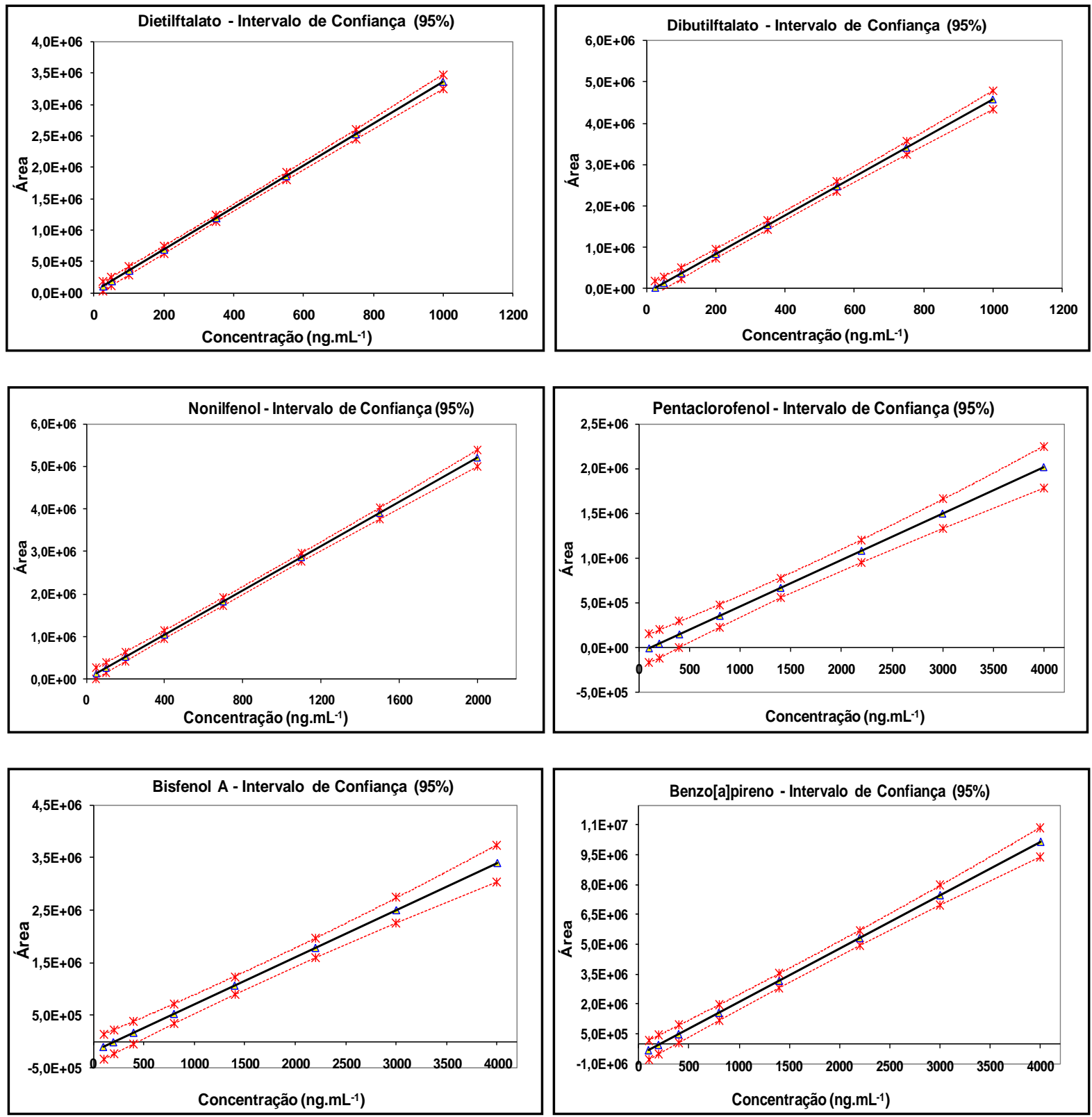

FIGURA 35. Gráficos da faixa de intervalo de confiança no ensaio sem matriz para os seis compostos estudados na faixa de trabalho considerada. 


\subsubsection{Limites de detecção e quantificação}

O limite de detecção (LD) da metodologia foi determinado pelo desvio padrão das replicatas $(n=7)$ da menor concentração dos analitos (definida após diluições sucessivas da solução dos padrões dos seis compostos em estudo) adicionadas às matrizes e somente nos solventes ( $\mathrm{EtOAc/MeOH,} \mathrm{60:40),}$ conforme a equação 11 descrita no item 5.4.3 desta dissertação.

Para determinação do limite de quantificação (LQ) utilizou-se o branco das amostras de água tratada e água bruta. Quando a matriz não apresentou sinal analítico para um determinado composto, ou no caso do branco de solventes (ensaio sem matriz), foram utilizadas as médias das replicatas $(n=7)$ da menor concentração do analito para definição de tal parâmetro, seguindo a equação 12 do capítulo 5 desta dissertação.

Nas TAB. 24 a 26 são apresentados os limites de detecção (LD) e de quantificação (LQ) do método, considerando $1 \mathrm{~L}$ de amostra concentrada mil vezes. Em função da sensibilidade do equipamento ser diferente para cada composto e variar também para cada matriz, os limites alcançados são distintos.

TABELA 24. Limite de detecção (LD) e limite de quantificação (LQ) para os seis compostos estudados na matriz de água tratada (AT).

\begin{tabular}{ccc}
\hline \multirow{2}{*}{ Composto } & \multicolumn{2}{c}{ LIMITES DO MÉTODo - MATRIz AT } \\
\cline { 2 - 3 } & LD $\left(\mu \mathrm{g} \cdot \mathrm{L}^{-1}\right)$ & $\mathrm{LQ}\left(\mu \mathrm{g} \cdot \mathrm{L}^{-1}\right)$ \\
\hline Dietilftalato & 0,007 & 0,023 \\
Dibutilftalato & 0,010 & 0,034 \\
Nonilfenol & 0,012 & 0,032 \\
Pentaclorofenol & 0,015 & 0,053 \\
Bisfenol A & 0,029 & 0,044 \\
Benzo[a]pireno & 0,050 & 0,082 \\
\hline
\end{tabular}


TABELA 25. Limite de detecção (LD) e limite de quantificação (LQ) para os seis compostos estudados na matriz de água bruta $(A B)$.

\begin{tabular}{ccc}
\hline \multirow{2}{*}{ Composto } & \multicolumn{2}{c}{ LIMITES Do MÉTODo - MATRIZ AB } \\
\cline { 2 - 3 } & $\mathrm{LD}\left(\mu \mathrm{g} \cdot \mathrm{L}^{-1}\right)$ & $\mathrm{LQ}\left(\mu \mathrm{g} \cdot \mathrm{L}^{-1}\right)$ \\
\hline Dietilftalato & 0,004 & 0,010 \\
Dibutilftalato & 0,008 & 0,050 \\
Nonilfenol & 0,020 & 0,060 \\
Pentaclorofenol & 0,013 & 0,114 \\
Bisfenol A & 0,026 & 0,158 \\
Benzo[a]pireno & 0,016 & 0,165 \\
\hline
\end{tabular}

TABELA 26. Limite de detecção (LD) e limite de quantificação (LQ) para os seis compostos estudados no ensaio sem matriz.

\begin{tabular}{ccc}
\hline \multirow{2}{*}{ Composto } & \multicolumn{2}{c}{ LIMITES Do MÉTODo - SEM MATRIZ } \\
\cline { 2 - 3 } & $\mathrm{LD}\left(\mu \mathrm{g} \cdot \mathrm{L}^{-1}\right)$ & $\mathrm{LQ}\left(\mu \mathrm{g} \cdot \mathrm{L}^{-1}\right)$ \\
\hline Dietilftalato & 0,003 & 0,033 \\
Nonilfenol & 0,005 & 0,064 \\
Pentaclorofenol & 0,014 & 0,166 \\
Dibutilftalato & 0,003 & 0,049 \\
Bisfenol A & 0,005 & 0,191 \\
Benzo[a]pireno & 0,005 & 0,189 \\
\hline
\end{tabular}

\subsubsection{Precisão}

A precisão da metodologia foi avaliada pelo coeficiente de variação (CV) e pelos limites de repetitividade ( $r$ ) e de reprodutibilidade $(R)$.

Nas TAB. 27 e 28 são expressos os coeficientes de variação (CV) de sete replicatas para os compostos estudados, em três níveis de concentrações, nos ensaios com as matrizes de água tratada e bruta. O CV ou desvio padrão relativo (DPR) das replicatas em todas as análises foram inferiores a $20 \%$, porcentagem de referência para análise de traços ou impurezas (Horwitz e Albert, 2006), como pode ser observado nas tabelas citadas. 
TABELA 27. Coeficientes de variação (CV \%) para os compostos em três níveis de concentração no ensaio com matriz de água tratada.

\begin{tabular}{ccccc}
\hline \multirow{2}{*}{ DietilfTALATO } & $\mu \mathrm{g} \cdot \mathrm{mL}^{-1}$ & 0,050 & 0,200 & 0,550 \\
\cline { 2 - 5 } & $\mathbf{C V}(\%)$ & $\mathbf{6 , 6 7}$ & $\mathbf{4 , 1 6}$ & $\mathbf{3 , 7 0}$ \\
\hline \hline \multirow{2}{*}{ DiBUtILFTALATO } & $\mu \mathrm{g} \cdot \mathrm{mL}^{-1}$ & 0,050 & 0,200 & 0,550 \\
\cline { 2 - 5 } & $\mathbf{C V}(\%)$ & $\mathbf{1 2 , 0 7}$ & $\mathbf{3 , 5 9}$ & $\mathbf{3 , 0 1}$ \\
\hline \multirow{2}{*}{ NONILFENOL } & $\mu \mathrm{g} \cdot \mathrm{mL}^{-1}$ & 0,050 & 0,200 & 0,700 \\
\cline { 2 - 5 } & $\mathbf{C V ~ ( \% )}$ & $\mathbf{4 , 9 7}$ & $\mathbf{5 , 4 0}$ & $\mathbf{8 , 0 7}$ \\
\hline \hline \multirow{2}{*}{ PENTACLOROFENOL } & $\mu \mathrm{g} \cdot \mathrm{mL}^{-1}$ & 0,200 & 0,800 & 2,200 \\
\cline { 2 - 5 } & $\mathbf{C V ~ ( \% )}$ & $\mathbf{1 2 , 0 1}$ & $\mathbf{1 1 , 0 0}$ & $\mathbf{8 , 0 5}$ \\
\hline \hline \multirow{2}{*}{ BISFENOL A } & $\mu \mathrm{g} \cdot \mathrm{mL}^{-1}$ & 0,200 & 0,800 & 2,200 \\
\cline { 2 - 5 } & $\mathbf{C V ~ ( \% )}$ & $\mathbf{1 0 , 8 2}$ & $\mathbf{1 0 , 8 5}$ & $\mathbf{6 , 4 0}$ \\
\hline \hline \multirow{2}{*}{ BENZO[A]PIRENO } & $\mu \mathrm{g} \cdot \mathrm{mL}^{-1}$ & 0,200 & 0,800 & 2,200 \\
\cline { 2 - 5 } & $\mathbf{C V ~ ( \% )}$ & $\mathbf{1 1 , 5 8}$ & $\mathbf{1 0 , 2 6}$ & $\mathbf{3 , 0 9}$ \\
\hline
\end{tabular}

TABELA 28. Coeficientes de variação (CV \%) para os compostos em três níveis de concentração no ensaio com matriz de água bruta.

\begin{tabular}{|c|c|c|c|c|}
\hline \multirow{2}{*}{ DIETILFTALATO } & $\mu \mathrm{g} \cdot \mathrm{mL}^{-1}$ & 0,050 & 0,200 & 0,550 \\
\hline & CV (\%) & 4,79 & 2,79 & 5,47 \\
\hline \multirow{2}{*}{ DIBUTILFTALATO } & $\mu \mathrm{g} \cdot \mathrm{mL}^{-1}$ & 0,050 & 0,200 & 0,550 \\
\hline & CV (\%) & 5,04 & 2,43 & 8,32 \\
\hline \multirow{2}{*}{ NONILFENOL } & $\mu \mathrm{g} \cdot \mathrm{mL}^{-1}$ & 0,050 & 0,200 & 0,700 \\
\hline & CV (\%) & 9,70 & 8,25 & 9,33 \\
\hline \multirow{2}{*}{ PENTACLOROFENOL } & $\mu \mathrm{g} \cdot \mathrm{mL}^{-1}$ & 0,200 & 0,800 & 2,200 \\
\hline & CV (\%) & 7,51 & 11,28 & 5,72 \\
\hline \multirow{2}{*}{ BISFENOL A } & $\mu \mathrm{g} \cdot \mathrm{mL}^{-1}$ & 0,200 & 0,800 & 2,200 \\
\hline & CV (\%) & 8,31 & 4,32 & 11,45 \\
\hline \multirow{2}{*}{ BENZO[A]PIRENO } & $\mu \mathrm{g} \cdot \mathrm{mL}^{-1}$ & 0,200 & 0,800 & 2,200 \\
\hline & CV (\%) & 9,49 & 7,15 & 9,81 \\
\hline
\end{tabular}

A repetitividade foi avaliada pelo limite de repetitividade ( $r$ ), cuja equação foi demonstrada no item 5.4 .5 do capítulo 5. Foram considerados três níveis de concentrações e sete replicatas de cada ensaio, as quais foram analisadas sob as mesmas condições (mesmo dia, equipamento e analista). As concentrações consideradas, as médias dos desvios padrão entre as replicatas e os resultados obtidos para as duas matrizes são apresentados nas TAB. 29 e 30. 
TABELA 29. Valores do limite de repetitividade ( $r$ ) para os compostos em três níveis de concentração no ensaio com matriz de água tratada.

\begin{tabular}{|c|c|c|c|c|}
\hline \multirow{3}{*}{ DIETILFTALATO } & $\mu \mathrm{g} \cdot \mathrm{mL}^{-1}$ & 0,050 & 0,200 & 0,550 \\
\hline & $\bar{S}$ replicatas & 0,003 & 0,008 & 0,021 \\
\hline & $r$ & 0,010 & 0,023 & 0,060 \\
\hline \multirow{3}{*}{ DIBUTILFTALATO } & $\mu \mathrm{g} \cdot \mathrm{mL}^{-1}$ & 0,050 & 0,200 & 0,550 \\
\hline & $\bar{S}$ replicatas & 0,007 & 0,007 & 0,019 \\
\hline & $r$ & 0,020 & 0,021 & 0,052 \\
\hline \multirow{3}{*}{ NONILFENOL } & $\mu \mathrm{g} \cdot \mathrm{mL}^{-1}$ & 0,050 & 0,200 & 0,700 \\
\hline & $\bar{S}$ replicatas & 0,005 & 0,015 & 0,053 \\
\hline & $r$ & 0,013 & 0,025 & 0,117 \\
\hline \multirow{3}{*}{ PENTACLOROFENOL } & $\mu \mathrm{g} \cdot \mathrm{mL}^{-1}$ & 0,200 & 0,800 & 2,200 \\
\hline & $\bar{S}$ replicatas & 0,023 & 0,102 & 0,186 \\
\hline & $r$ & 0,064 & 0,284 & 0,520 \\
\hline \multirow{3}{*}{ BISFENOL A } & $\mu \mathrm{g} \cdot \mathrm{mL}^{-1}$ & 0,200 & 0,800 & 2,200 \\
\hline & $\bar{S}$ replicatas & 0,023 & 0,088 & 0,165 \\
\hline & $r$ & 0,065 & 0,248 & 0,463 \\
\hline \multirow{3}{*}{ BENZO[A]PIRENO } & $\mu \mathrm{g} \cdot \mathrm{mL}^{-1}$ & 0,200 & 0,800 & 2,200 \\
\hline & $\bar{S}$ replicatas & 0,034 & 0,111 & 0,097 \\
\hline & $\mathbf{r}$ & 0,096 & 0,311 & 0,272 \\
\hline
\end{tabular}

TABELA 30. Valores do limite de repetitividade ( $r$ ) para os compostos em três níveis de concentração no ensaio com matriz de água bruta.

\begin{tabular}{|c|c|c|c|c|}
\hline & $\mu \mathrm{g} \cdot \mathrm{mL}^{-1}$ & 0,050 & 0,200 & 0,550 \\
\hline \multirow[t]{2}{*}{ DIETILFTALATO } & $\bar{S}$ replicatas & 0,003 & 0,006 & 0,033 \\
\hline & $\bar{r}$ & 0,008 & 0,017 & 0,093 \\
\hline \multirow{3}{*}{ DIBUTILFTALATO } & $\mu \mathrm{g} \cdot \mathrm{mL}^{-1}$ & 0,050 & 0,200 & 0,550 \\
\hline & $\bar{S}$ replicatas & 0,003 & 0,005 & 0,049 \\
\hline & $r$ & 0,009 & 0,013 & 0,137 \\
\hline \multirow{3}{*}{ NONILFENOL } & $\mu \mathrm{g} \cdot \mathrm{mL}^{-1}$ & 0,050 & 0,200 & 0,700 \\
\hline & $\bar{S}$ replicatas & 0,008 & 0,017 & 0,058 \\
\hline & $r$ & 0,023 & 0,047 & 0,163 \\
\hline \multirow{3}{*}{ PENTACLOROFENOL } & $\mu \mathrm{g} \cdot \mathrm{mL}^{-1}$ & 0,200 & 0,800 & 2,200 \\
\hline & $\bar{S}$ replicatas & 0,015 & 0,074 & 0,120 \\
\hline & $r$ & 0,042 & 0,206 & 0,335 \\
\hline \multirow{3}{*}{ BISFENOL A } & $\mu \mathrm{g} \cdot \mathrm{mL}^{-1}$ & 0,200 & 0,800 & 2,200 \\
\hline & $\bar{S}$ replicatas & 0,024 & 0,036 & 0,375 \\
\hline & $r$ & 0,068 & 0,100 & 1,049 \\
\hline \multirow{3}{*}{ BENZO[A]PIRENO } & $\mu \mathrm{g} \cdot \mathrm{mL}^{-1}$ & 0,200 & 0,800 & 2,200 \\
\hline & $\bar{S}$ replicatas & 0,025 & 0,060 & 0,284 \\
\hline & $\mathbf{r}$ & 0,069 & 0,169 & 0,796 \\
\hline
\end{tabular}


Ainda para avaliação da precisão, considerou-se a reprodutibilidade do método por meio do cálculo do limite de reprodutibilidade $(R)$ conforme a equação 14 apresentada no item 5.4.5. Foram realizadas análises em setuplicata da solução mista dos padrões nas duas matrizes e nos três níveis de concentrações, entretanto, em dias diferentes. As TAB. 31 e 32 mostram os resultados obtidos, assim como os três níveis de concentração considerados e as médias dos desvios padrão entre as replicatas.

TABELA 31. Valores do limite de reprodutibilidade $(R)$ para os compostos em três níveis de concentração no ensaio com matriz de água tratada.

\begin{tabular}{|c|c|c|c|c|}
\hline & $\mu \mathrm{g} \cdot \mathrm{mL}^{-1}$ & 0,050 & 0,200 & 0,550 \\
\hline \multirow[t]{3}{*}{ DIETILFTALATO } & $\bar{S}$ replicatas & 0,002 & 0,003 & 0,016 \\
\hline & $\mathbf{R}$ & 0,005 & 0,009 & 0,044 \\
\hline & $\mu \mathrm{g} \cdot \mathrm{mL}^{-1}$ & 0,050 & 0,200 & 0,550 \\
\hline \multirow[t]{3}{*}{ DIBUTILFTALATO } & $\bar{S}$ replicatas & 0,004 & 0,002 & 0,014 \\
\hline & $\mathbf{R}$ & 0,011 & 0,007 & 0,039 \\
\hline & $\mu \mathrm{g} \cdot \mathrm{mL}^{-1}$ & 0,050 & 0,200 & 0,700 \\
\hline \multirow[t]{3}{*}{ NONILFENOL } & $\bar{S}$ replicatas & 0,002 & 0,007 & 0,029 \\
\hline & $\mathbf{R}$ & 0,005 & 0,020 & 0,081 \\
\hline & $\mu \mathrm{g} \cdot \mathrm{mL}^{-1}$ & 0,200 & 0,800 & 2,200 \\
\hline \multirow[t]{3}{*}{ PENTACLOROFENOL } & $\bar{S}$ replicatas & 0,015 & 0,072 & 0,117 \\
\hline & $\mathbf{R}$ & 0,043 & 0,201 & 0,328 \\
\hline & $\mu \mathrm{g} \cdot \mathrm{mL}^{-1}$ & 0,200 & 0,800 & 2,200 \\
\hline \multirow[t]{3}{*}{ BISFENOL A } & $\bar{S}$ replicatas & 0,015 & 0,057 & 0,116 \\
\hline & $\mathbf{R}$ & 0,042 & 0,160 & 0,324 \\
\hline & $\mu \mathrm{g} \cdot \mathrm{mL}^{-1}$ & 0,200 & 0,800 & 2,200 \\
\hline \multirow[t]{2}{*}{ BENZO[A]PIRENO } & $\bar{S}$ replicatas & 0,024 & 0,077 & 0,058 \\
\hline & $\mathbf{R}$ & 0,067 & 0,216 & 0,163 \\
\hline
\end{tabular}

TABELA 32. Valores do limite de reprodutibilidade $(R)$ para os compostos em três níveis de concentração no ensaio com matriz de água bruta.

\begin{tabular}{lcccc}
\hline \multirow{3}{*}{ DIETILFTALATO } & $\mu \mathrm{g} \cdot \mathrm{mL}^{-1}$ & 0,050 & 0,200 & 0,550 \\
\cline { 2 - 5 } & $\bar{S}$ replicatas & 0,001 & 0,002 & 0,015 \\
\cline { 2 - 5 } & $\mathbf{R}$ & $\mathbf{0 , 0 0 3}$ & $\mathbf{0 , 0 0 5}$ & $\mathbf{0 , 0 4 1}$ \\
\hline \multirow{3}{*}{ DIBUTILFTALATO } & $\mu \mathrm{g} \cdot \mathrm{mL}^{-1}$ & 0,050 & 0,200 & 0,550 \\
\cline { 2 - 5 } & $\bar{S}$ replicatas & 0,001 & 0,001 & 0,020 \\
\cline { 2 - 5 } & $\mathbf{R}$ & $\mathbf{0 , 0 0 4}$ & $\mathbf{0 , 0 0 3}$ & $\mathbf{0 , 0 5 5}$ \\
\hline
\end{tabular}




\begin{tabular}{ccccc}
...continuação TABELA 32. & \multicolumn{3}{l}{} \\
\hline \multirow{3}{*}{ NONILFENOL } & $\mu \mathrm{gg} \cdot \mathrm{mL}^{-1}$ & 0,050 & 0,200 & 0,700 \\
\cline { 2 - 5 } & $\bar{S}$ replicatas & 0,006 & 0,007 & 0,034 \\
\cline { 2 - 5 } & $\mathbf{R}$ & $\mathbf{0 , 0 1 6}$ & $\mathbf{0 , 0 2 0}$ & $\mathbf{0 , 1 0 3}$ \\
\hline \multirow{3}{*}{ PENTACLOROFENOL } & $\overline{\mu g} \cdot \mathrm{mL}^{-1}$ & 0,200 & 0,800 & 2,200 \\
\cline { 2 - 5 } & $\bar{S}$ replicatas & 0,009 & 0,023 & 0,090 \\
\cline { 2 - 5 } & $\mathbf{R}$ & $\mathbf{0 , 0 2 5}$ & $\mathbf{0 , 0 8 0}$ & $\mathbf{0 , 2 5 3}$ \\
\hline \multirow{3}{*}{ BISFENOL A } & $\overline{\mu g} \cdot \mathrm{mL}^{-1}$ & 0,200 & 0,800 & 2,200 \\
& $\bar{S}$ replicatas & 0,018 & 0,013 & 0,175 \\
\cline { 2 - 5 } & $\mathbf{R}$ & $\mathbf{0 , 0 5 0}$ & $\mathbf{0 , 0 3 7}$ & $\mathbf{0 , 4 9 1}$ \\
\hline \multirow{3}{*}{ BENZO[A]PIRENO } & $\overline{\mu g} \cdot \mathrm{mL}^{-1}$ & 0,200 & 0,800 & 2,200 \\
\cline { 2 - 5 } & $\bar{S}$ replicatas & 0,017 & 0,020 & 0,118 \\
\cline { 2 - 5 } & $\mathbf{R}$ & $\mathbf{0 , 0 4 7}$ & $\mathbf{0 , 0 5 7}$ & $\mathbf{0 , 3 2 9}$
\end{tabular}

Para que a metodologia apresente repetitividade e reprodutibilidade os valores de $r$ e $\mathrm{R}$ devem ser superiores à diferença entre as replicatas (Chiu et al., 2009). Como pode ser observado nas TAB. 29 a 32, os resultados apresentados foram bem inferiores às concentrações consideradas e os limites para repetibilidade $(r)$ e reprodutibilidade $(R)$ estão acima das médias do desvio padrão das replicatas. Além disso, para os três níveis de concentração avaliados, as diferenças absolutas entre os resultados das replicatas do ensaio obtidos sob condições de repetibilidade e reprodutibilidade foram inferiores aos valores de $r$ e $\mathrm{R}$, demonstrando a precisão do método (ISO,1998).

\subsubsection{Exatidão}

Diferentes ferramentas podem ser utilizadas para avaliação da exatidão de um método analítico. Entre elas, a tabela ANOVA, cujos resultados foram descritos nas TAB. 22 e 23 deste capítulo, o teste z Score e os ensaios de recuperação, utilizando materiais de referência certificados.

Para aplicação do z Score foram consideradas as replicatas dos ensaios com e sem matriz, e a equação 15 apresentada no item 5.4.6. Para que a metodologia seja considerada exata, os valores de $|z|$ devem ser inferiores a 2 , caso o $|z|$ esteja entre 2 e 3 , o resultado é questionável, e para $|z|>3$, o resultado é insatisfatório. 
Como pode ser observado na TAB. 33 o índice z resultou em valores < 2, evidenciando que os resultados são satisfatórios e o método tem exatidão na faixa de concentração considerada tanto nos ensaios com as matrizes de água tratada e água bruta, como no ensaio somente na solução de solventes.

TABELA 33. Resultados do z Score para os compostos estudados nos ensaios em matriz de água tratada (AT) e água bruta $(A B)$.

\begin{tabular}{cccc}
\hline \multirow{2}{*}{ Composto } & $\begin{array}{c}\text { ConcentraçÃo } \\
\left(\mu \mathrm{g} \cdot \mathrm{mL}^{-1}\right)\end{array}$ & \multicolumn{2}{c}{ z Score } \\
\cline { 3 - 4 } & 0,025 & 0,14 & 1,81 \\
\hline Dietilftalato & 0,100 & 0,63 & 0,34 \\
Dibutilftalato & 0,200 & 1,23 & 0,27 \\
Nonilfenol & 0,200 & 1,43 & 1,36 \\
Pentaclorofenol & 0,400 & 0,27 & 0,08 \\
Bisfenol A & 0,200 & 0,24 & 1,81 \\
Benzo[a]pireno & & &
\end{tabular}

\subsubsection{Estudos de recuperação}

A eficiência da metodologia proposta foi avaliada por meio dos ensaios de recuperação nas duas matrizes, para tanto foram utilizadas amostras provenientes da cidade de Guararema, por ter apresentado os menores índices de contaminação pelos xenoestrógenos nas amostragens anteriores e por ser a mais rica em ácidos orgânicos.

O ensaio de recuperação foi realizado de acordo com o descrito no item 5.4.7 desta dissertação. A análise dessas amostras demonstrou que tanto a água tratada quanto a água bruta apresentavam contaminação por alguns dos compostos estudados. As concentrações desses analitos foram descontadas de cada ensaio de recuperação para não superestimar a eficiência do método.

A porcentagem de recuperação foi calculada pela equação 3 apresentada do item 3.8.6 desta dissertação. Os três níveis de fortificação baixo, médio e alto, foram estabelecidos tendo como base o intervalo linear das curvas analíticas. 
Como pode ser observado nas TAB. 34 e 35 as porcentagens de recuperação variaram, exceto para o benzo[a]pireno, de $63 \%$ a $111 \%$ na matriz de água tratada, e na água bruta estiveram entre 70\% e 120\%, demonstrando que para os demais compostos os valores de recuperação estão dentro da faixa recomendada pela literatura, de 70 a 120\% para análise de resíduos, ou de 50 a $120 \%$ para amostras complexas (Ribani et al., 2004).

Porcentagens de recuperação acima de $100 \%$ podem ser explicadas pela influência da matriz sobre o ensaio, especialmente quando se tratam de matrizes complexas, como as ambientais. A variação dos resultados deve-se ao fato dos analitos pertencerem a classes químicas distintas e apresentarem comportamentos diferentes quando presentes nas amostras em estudo.

O HPA benzo[a]pireno é o que sofre maior influência das matrizes, ou ainda por ser um composto formado por anéis benzenos fundidos, os solventes escolhidos nessa metodologia ( $\mathrm{EtOAc/MeOH,} \mathrm{60:40)} \mathrm{não} \mathrm{foram} \mathrm{capazes} \mathrm{de} \mathrm{extrair}$ com eficiência este analito das amostras. Utilizando acetona como co-solvente e eluição com a mistura THF/Acet (50:50, v/v), Brito (2009) alcançou recuperação média de $70 \%$ para este HPA.

TABELA 34. Resultados dos estudos de recuperação na matriz de água tratada (AT) considerando três níveis de fortificação $(n=3)$.

\begin{tabular}{ccccccc}
\hline \multirow{2}{*}{ Composto } & \multicolumn{7}{c}{ RECUPERAÇõES - MATRIz AT } \\
\cline { 2 - 7 } & $\begin{array}{c}\text { Nível baixo } \\
\left(\mu \mathrm{g} . \mathrm{L}^{-1}\right)\end{array}$ & $\begin{array}{c}\text { Rec } \\
(\%)\end{array}$ & $\begin{array}{c}\text { Nível médio } \\
\left(\mu g . \mathrm{L}^{-1}\right)\end{array}$ & $\begin{array}{c}\text { Rec } \\
(\%)\end{array}$ & $\begin{array}{c}\text { Nível alto } \\
\left(\mu \mathrm{g} . \mathrm{L}^{-1}\right)\end{array}$ & $\begin{array}{c}\text { Rec } \\
(\%)\end{array}$ \\
\hline Dietilftalato & 0,075 & $\mathbf{1 0 5}$ & 0,40 & $\mathbf{7 6}$ & 1,00 & $\mathbf{8 2}$ \\
Dibutilftalato & 0,075 & $\mathbf{8 7}$ & 0,40 & $\mathbf{7 2}$ & 1,00 & $\mathbf{9 4}$ \\
Nonilfenol & 0,150 & $\mathbf{1 1 1}$ & 0,80 & $\mathbf{7 2}$ & 2,00 & $\mathbf{8 3}$ \\
Pentaclorofenol & 0,315 & $\mathbf{7 2}$ & 1,68 & $\mathbf{8 8}$ & 4,20 & $\mathbf{9 5}$ \\
Bisfenol A & 0,300 & $\mathbf{1 0 5}$ & 1,60 & $\mathbf{6 3}$ & 4,00 & $\mathbf{8 0}$ \\
Benzo[a]pireno & 0,300 & $\mathbf{5 9}$ & 1,60 & $\mathbf{2 3}$ & 4,00 & $\mathbf{2 8}$ \\
\hline
\end{tabular}


TABELA 35. Resultados dos estudos de recuperação na matriz de água bruta $(A B)$ considerando três níveis de fortificação $(n=3)$.

\begin{tabular}{ccccccc}
\hline \multirow{2}{*}{ Composto } & \multicolumn{7}{c}{ ReCUPERAÇões - MATRIz AB } \\
\cline { 2 - 7 } & $\begin{array}{c}\text { Nível baixo } \\
\left(\mu \mathrm{g} . \mathrm{L}^{-1}\right)\end{array}$ & $\begin{array}{c}\text { Rec } \\
(\%)\end{array}$ & $\begin{array}{c}\text { Nível médio } \\
\left(\mu \mathrm{g} \cdot \mathrm{L}^{-1}\right)\end{array}$ & $\begin{array}{c}\text { Rec } \\
(\%)\end{array}$ & $\begin{array}{c}\text { Nível alto } \\
\left(\mu \mathrm{g} \cdot \mathrm{L}^{-1}\right)\end{array}$ & $\begin{array}{c}\text { Rec } \\
(\%)\end{array}$ \\
\hline Dietilftalato & 0,075 & $\mathbf{1 0 2}$ & 0,40 & $\mathbf{1 0 7}$ & 1,00 & $\mathbf{8 4}$ \\
Dibutilftalato & 0,075 & $\mathbf{9 5}$ & 0,40 & $\mathbf{8 1}$ & 1,00 & $\mathbf{7 0}$ \\
Nonilfenol & 0,150 & $\mathbf{1 1 5}$ & 0,80 & $\mathbf{7 2}$ & 2,00 & $\mathbf{9 2}$ \\
Pentaclorofenol & 0,315 & $\mathbf{1 1 1}$ & 1,68 & $\mathbf{1 0 8}$ & 4,20 & $\mathbf{7 9}$ \\
Bisfenol A & 0,300 & $\mathbf{9 5}$ & 1,60 & $\mathbf{1 2 0}$ & 4,00 & $\mathbf{8 3}$ \\
Benzo[a]pireno & 0,300 & $\mathbf{3 3}$ & 1,60 & $\mathbf{4 2}$ & 4,00 & $\mathbf{2 5}$ \\
\hline
\end{tabular}

\subsubsection{Ensaios de Robustez}

Com o intuito de verificar a sensibilidade do método frente a pequenas variações, os parâmetros selecionados na TAB. 10 do capítulo 5 foram ordenados em 8 experimentos diferentes seguindo o planejamento fatorial saturado que é apresentado na TAB. 3 do capítulo 3 dessa dissertação.

Os resultados obtidos podem ser melhor entendidos por meio das representações gráficas, onde é possível avaliar se o método é robusto para as alterações nos parâmetros escolhidos, se os efeitos são ou não significativos, assim como ordenar a influência das variações nos resultados finais.

Nas FIG. 36 e 39 são apresentados os gráficos dos efeitos para os seis compostos estudados nas matrizes de água tratada e bruta, onde é possível avaliar se o parâmetro selecionado influencia positiva ou negativamente o ensaio. Os gráficos de probabilidade normal e de rankit (meia-normal) podem ser visualizados nas FIG. 37 e 38 e FIG. 40 e 41, também para os ensaios em água tratada e água bruta. Nestes gráficos cada ponto representa um parâmetro escolhido, e para que a metodologia seja considerada robusta os mesmo devem estar baixo da margem de erro mais crítica (ME, margin of error), se o resultado estiver entre a ME e a SME (simultaneous margin of error) pode ocorrer um falso negativo. 
Como pode ser observado na FIG. 36, para todos os compostos na matriz de AT o fator de maior influência positiva foi a voltagem do detector, todavia este parâmetro ficou abaixo da ME nos gráficos de rankit (FIG. 38 e 39), e alterando-se a voltagem do detector de 2,5 Kv para 2,3 Kv obteve-se um menor sinal analítico, o que corroborou para manter o valor nominal deste fator. $O$ aumento no fluxo da coluna de 1,6 para 1,8 $\mathrm{mL} \cdot \mathrm{min}^{-1}$, assim como as alterações na temperatura do injetor e da interface, mostraram influenciar negativamente o método para todos os compostos. A proporção da mistura extratora demonstrou efeito positivo apenas para o pentaclorofenol. $\mathrm{O} \mathrm{pH}$ da amostra mostrou melhorar significativamente a extração dos compostos BPA, B[a]P e PCP.
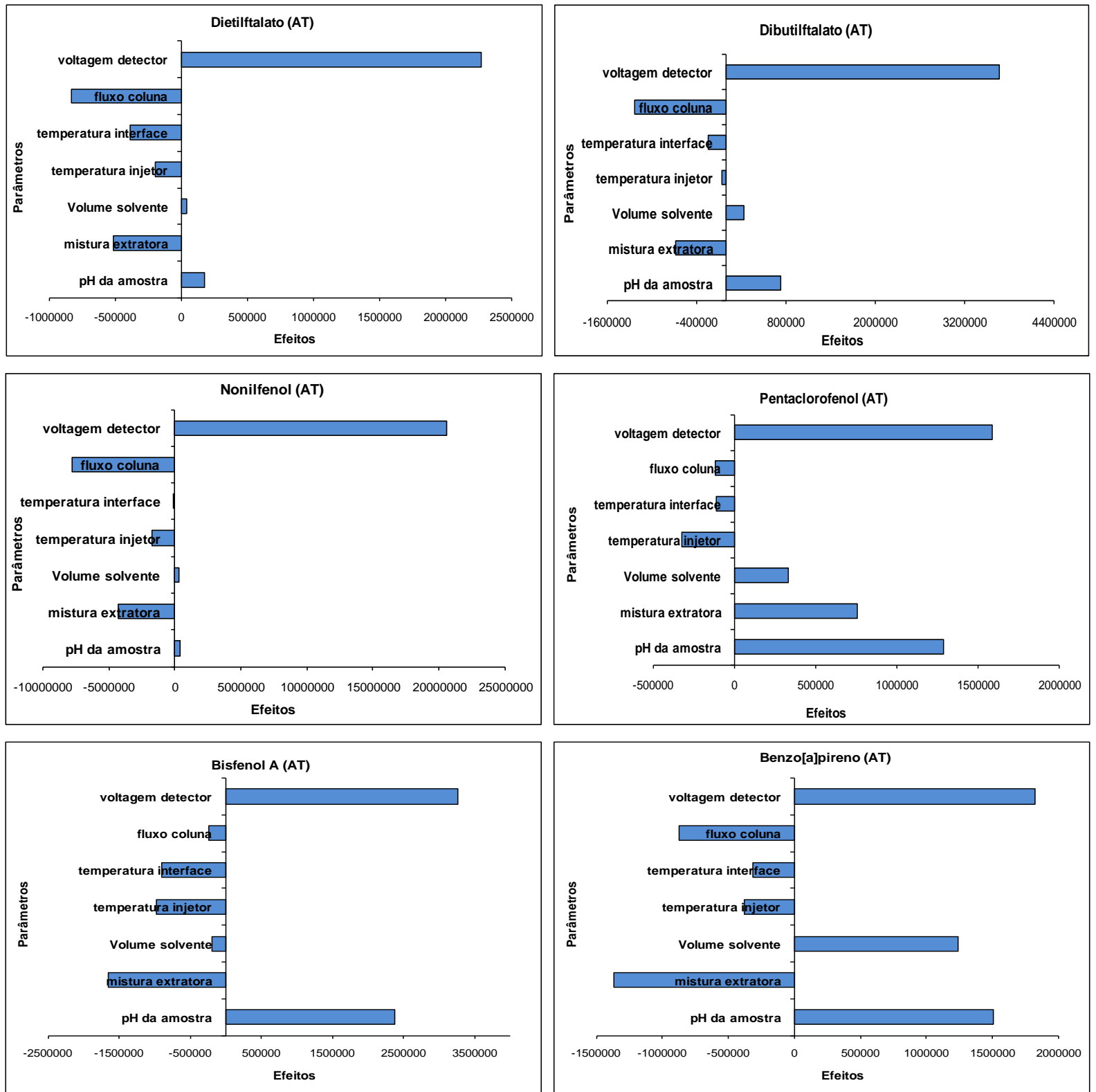

FIGURA 36. Representação gráfica do teste de verificação de significância dos efeitos no ensaio de robustez em água tratada (AT). 
A avaliação das FIG. 37 e 38 permite aferir que não é necessária a alteração de nenhum parâmetro na metodologia para extração e análise das amostras de água tratada, uma vez que todos os fatores ficaram abaixo da margem de erro mais crítica (ME). Os gráficos de probabilidade normal apresentaram valores entre -2 e +2 , ou seja, bem distribuídos, significando que provavelmente não haja outliers.
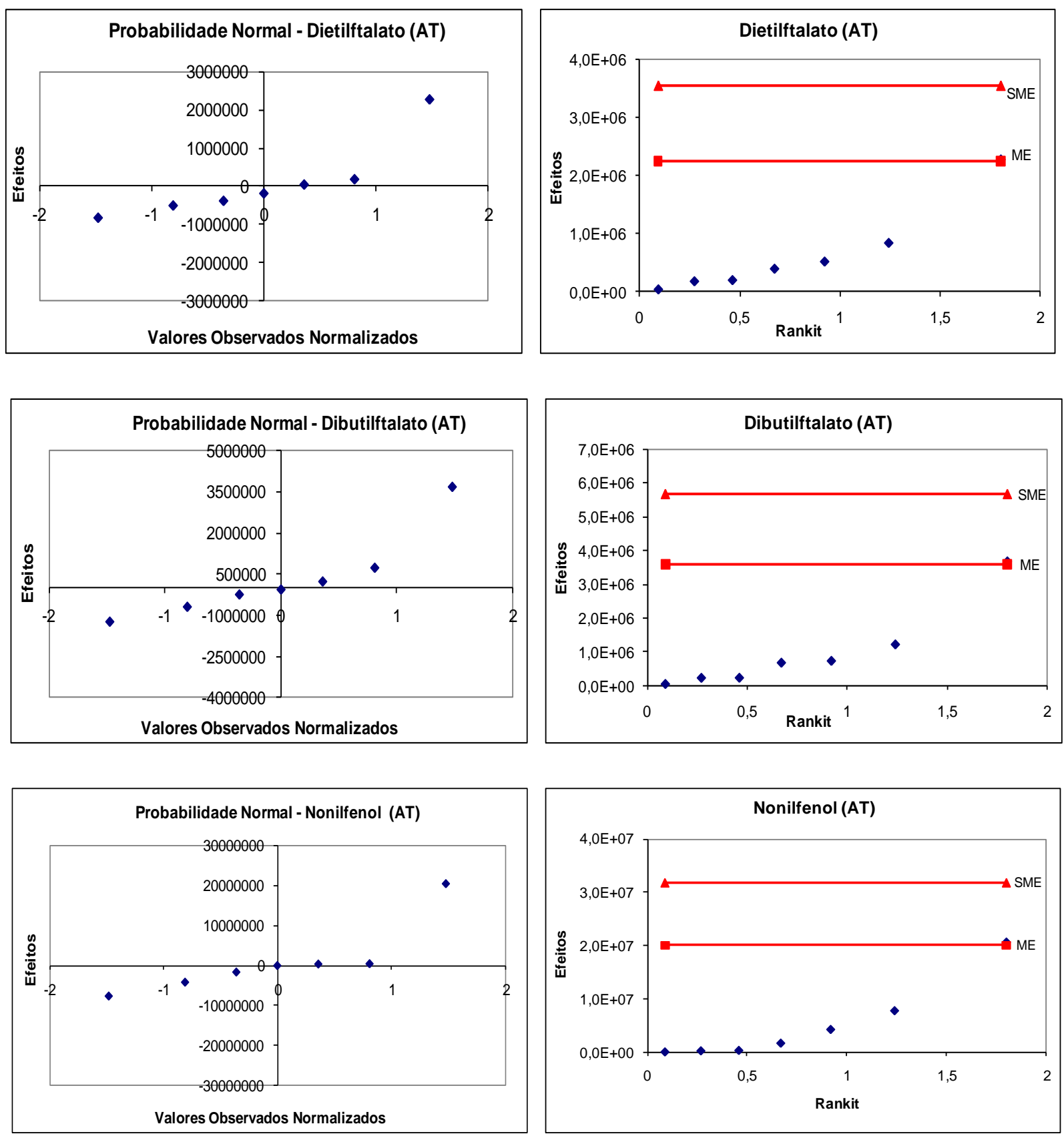

FIGURA 37. Gráficos de probabilidade normal (esquerda) e meia-normal (direita) do ensaio de robustez em água tratada (AT) para os compostos dietilftalato, dibutilftalato e nonilfenol. 

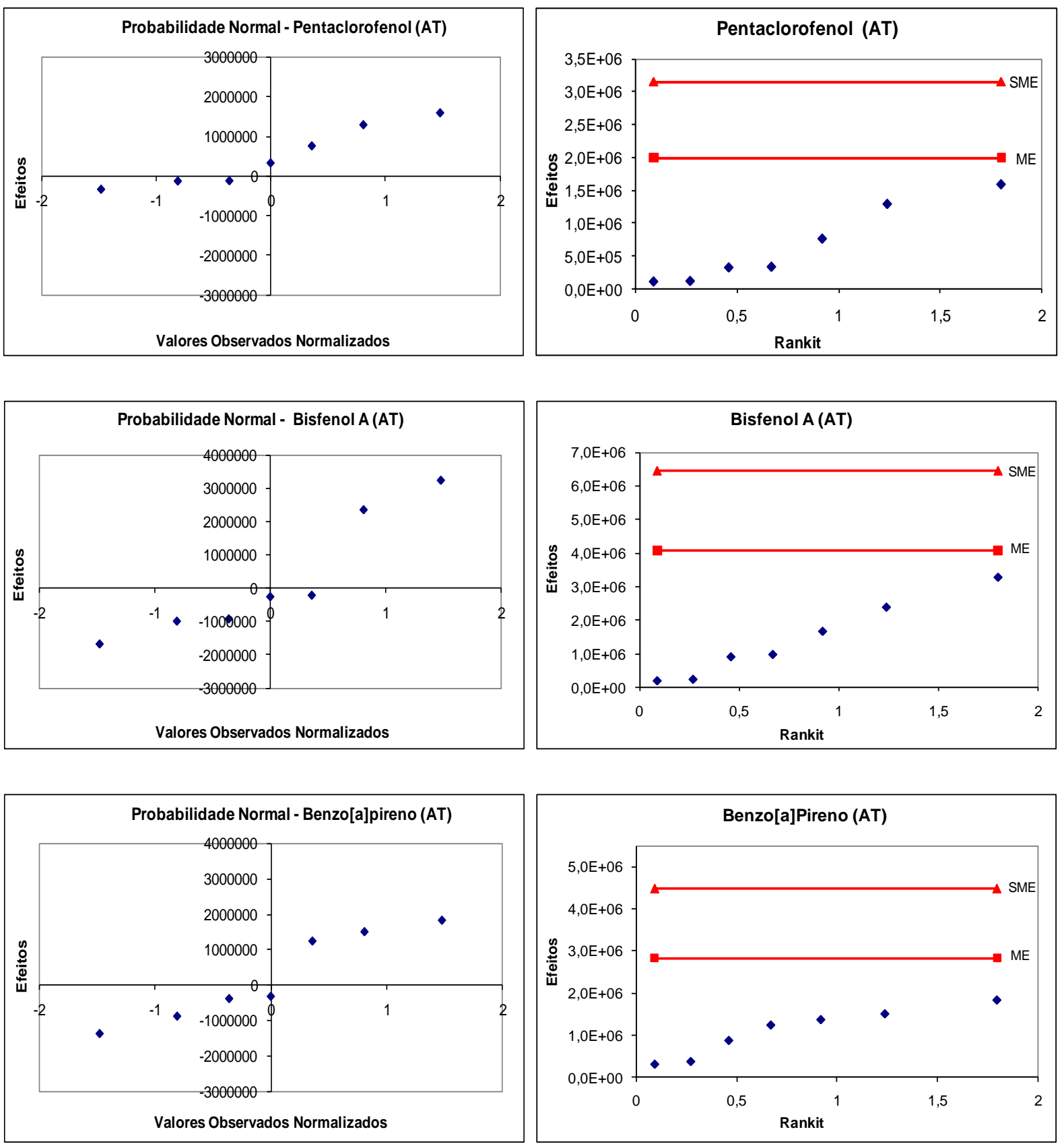

FIGURA 38. Gráficos de probabilidade normal (esquerda) e meia-normal (direita) do ensaio de robustez em água tratada (AT) para os compostos pentaclorofenol, bisfenol A e benzo[a]pireno. 
Como pode ser observado nos gráficos da FIG. 39, a alteração nos parâmetros mostrou maior influência positiva na matriz de água bruta quando comparado à água tratada. Para os compostos ftalatos e nonilfenol apenas o aumento no fluxo da coluna e no volume de solvente na eluição prejudicaria a análise dos mesmos. Para o PCP e o BPA, além da alteração no fluxo da coluna, a temperatura da interface e do injetor mostraram influência negativa. A alteração de todos os parâmetros beneficiaria a análise do benzo[a]pireno.
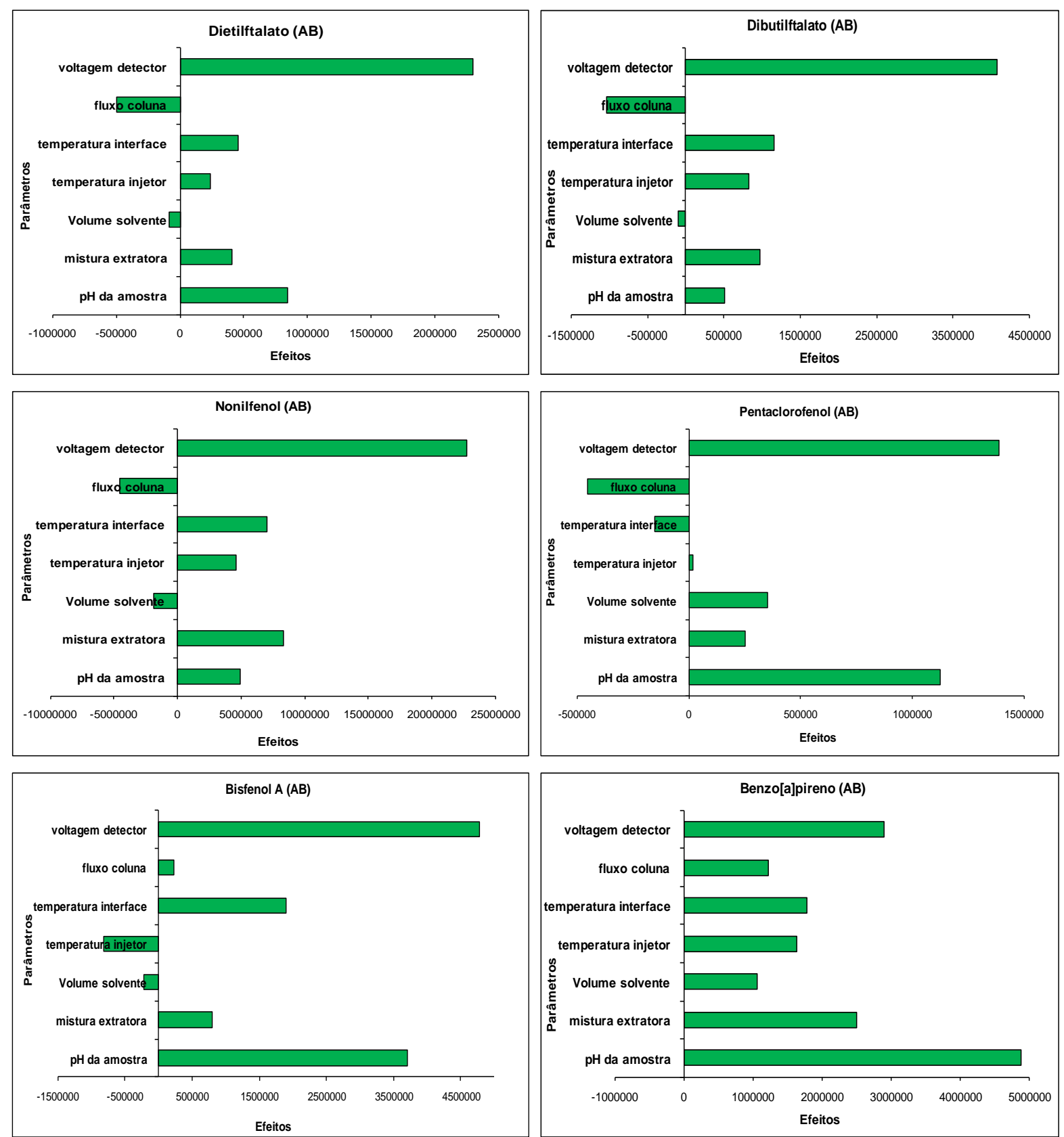

FIGURA 39. Representação gráfica do teste de verificação de significância dos efeitos no ensaio de robustez em água bruta. 
Todavia, avaliando-se os gráficos de meia-normal das FIG. 40 e 41, nota-se que os efeitos proporcionados pela alteração nos parâmetros encontramse abaixo ME para todos os compostos, e que, da mesma forma que no ensaio com água tratada, a voltagem do detector foi o fator que mais se aproximou do limite crítico (ME), indicando que maior atenção deve ser dada a este parâmetro. A distribuição dos valores entre -2 e +2 nos gráficos de probabilidade normal demonstram que os mesmo estão bem distribuídos, e que as alterações na metodologia não afetam de forma significativa os resultados.
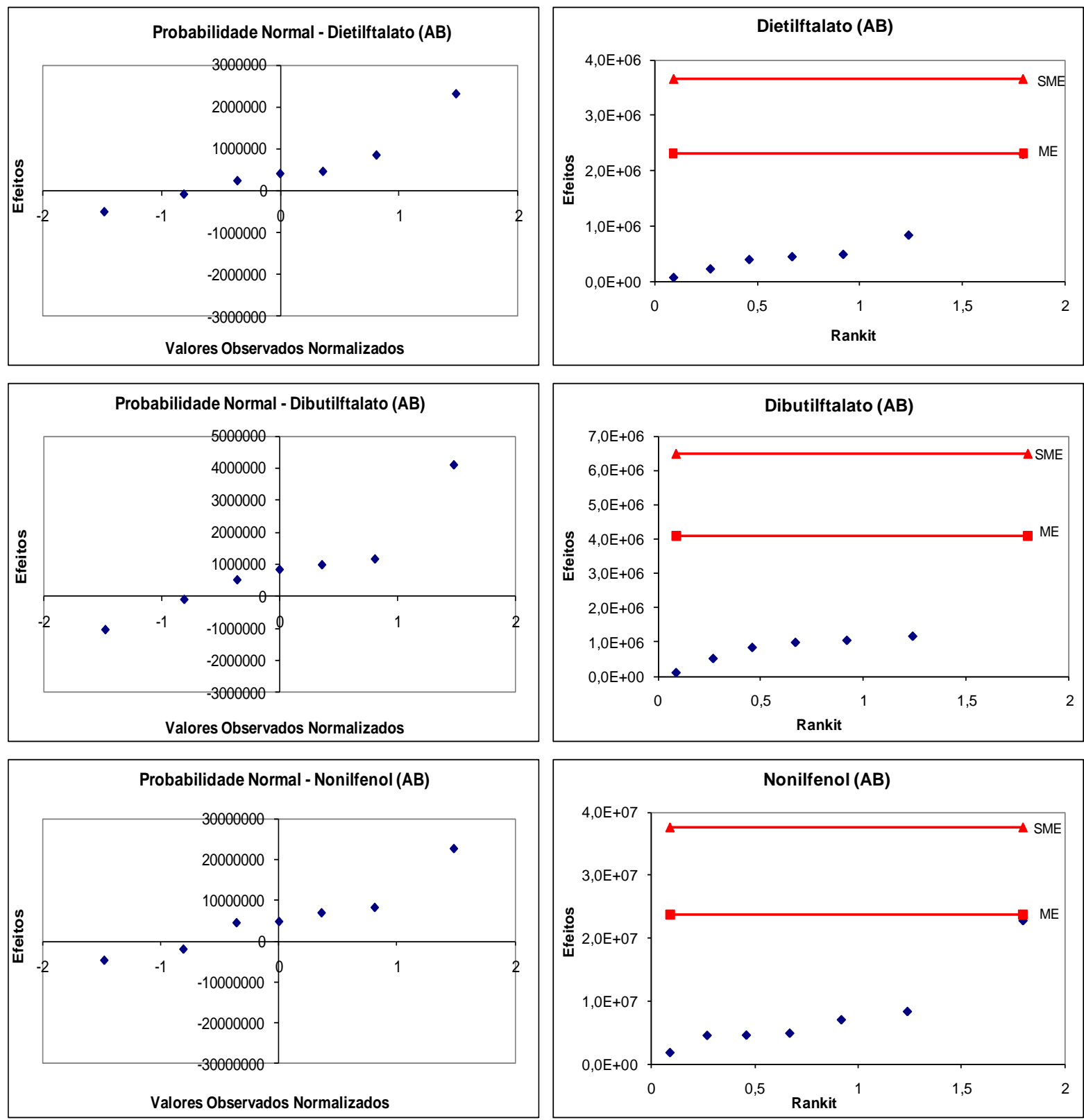

FIGURA 40. Gráficos de probabilidade normal (esquerda) e meia-normal (direita) do ensaio de robustez em água bruta (AB) para os compostos dietilftalato, dibutilftalato e nonilfenol. 

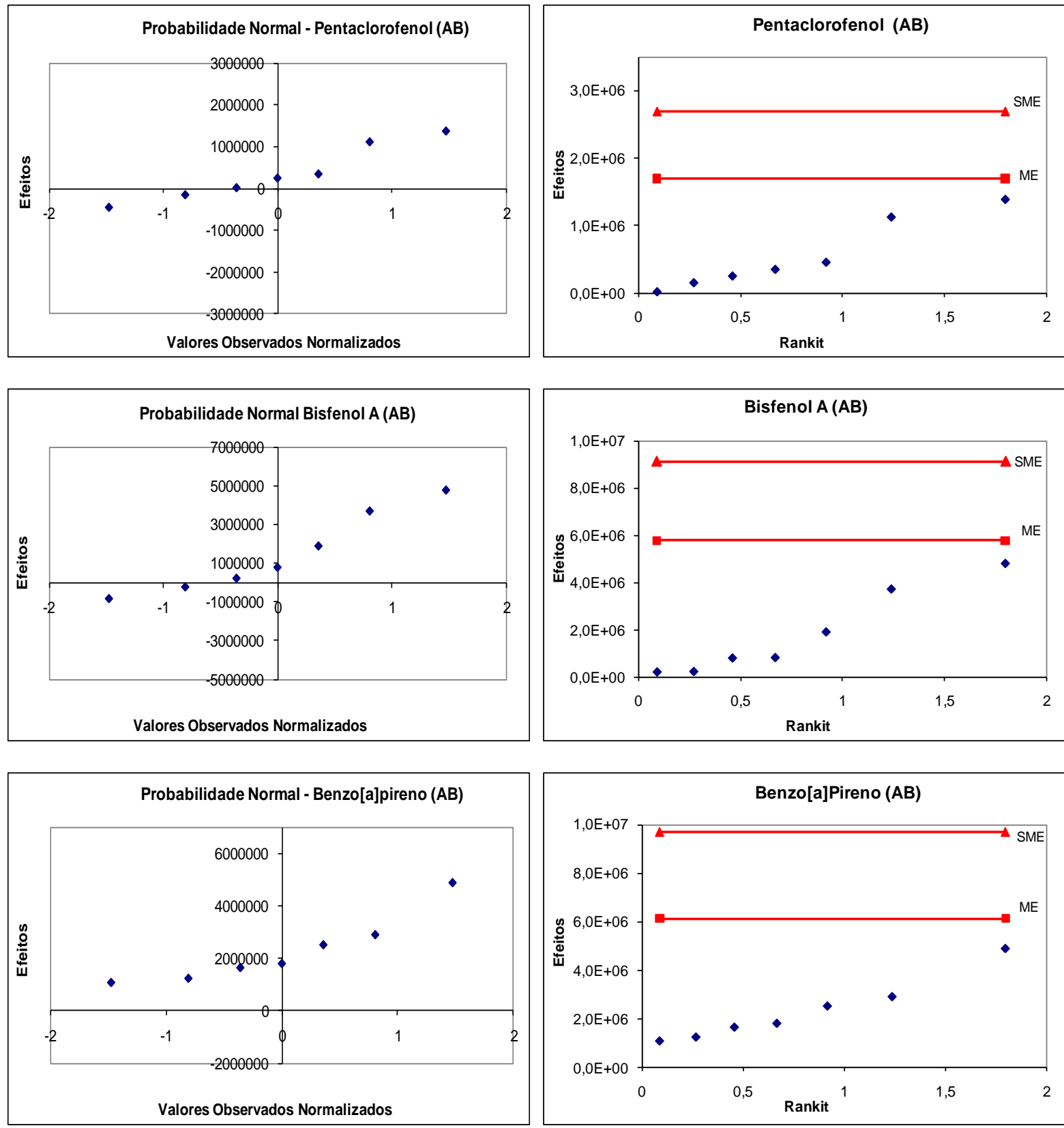

FIGURA 41. Gráficos de probabilidade normal (esquerda) e meia-normal (direita) do ensaio de robustez em água bruta $(\mathrm{AB})$ para os compostos pentaclorofenol, bisfenol A e benzo[a]pireno.

\subsubsection{Incertezas da medição}

Para a estimativa das incertezas dos compostos estudados seguiu-se os cálculos descritos no item 5.4 .9 dessa dissertação. Os resultados das incertezas expandidas, considerando-se o ponto médio do intervalo de concentração das curvas analíticas em água tratada e água bruta são 
apresentados nas TAB. 36 e 37. Pelo baixo valor de recuperação obtido para o benzo[a]pireno, a incerteza não foi calculada para este composto.

TABELA 36. Incertezas expandidas para os xenoestrógenos estudados referentes ao ponto intermediário das curvas analíticas em água tratada (AT), considerando $k=1,96$ e $95 \%$ de confiança.

\begin{tabular}{|c|c|c|c|c|}
\hline \multirow{2}{*}{ COMPOSTO } & \multicolumn{4}{|c|}{ MATRIZ AT } \\
\hline & CONCENTRAÇÃO $\left(\mu \mathrm{g} \cdot \mathrm{L}^{-1}\right)$ & & INCERTEZA EXPANDIDA & $\%$ \\
\hline Dietilftalato & 0,182 & \pm & 0,008 & 4,35 \\
\hline Dibutilftalato & 0,223 & \pm & 0,012 & 5,21 \\
\hline Nonilfenol & 0,365 & \pm & 0,014 & 3,94 \\
\hline Pentaclorofenol & 0,922 & \pm & 0,066 & 7,16 \\
\hline Bisfenol A & 1,114 & \pm & 0,042 & 3,78 \\
\hline
\end{tabular}

TABELA 37. Incertezas expandidas para os xenoestrógenos estudados referentes ao ponto intermediário das curvas analíticas em água bruta (AB), considerando $\mathrm{k}=1,96$ e $95 \%$ de confiança.

\begin{tabular}{|c|c|c|c|c|}
\hline \multirow{2}{*}{ CoMposto } & \multicolumn{4}{|c|}{ MATRIZ AB } \\
\hline & CONCENTRAÇÃO $\left(\mu \mathrm{g} \cdot \mathrm{L}^{-1}\right)$ & & INCERTEZA EXPANDIDA & $\%$ \\
\hline Dietilftalato & 0,195 & \pm & 0,009 & 4,97 \\
\hline Dibutilftalato & 0,235 & \pm & 0,009 & 3,86 \\
\hline Nonilfenol & 0,415 & \pm & 0,024 & 5,86 \\
\hline Pentaclorofenol & 0,908 & \pm & 0,047 & 5,18 \\
\hline Bisfenol A & 0,772 & \pm & 0,099 & 12,78 \\
\hline
\end{tabular}

No APÊNDICE 1 encontram-se os valores de todas as incertezas envolvidas nos cálculos de incertezas para cinco dos seis compostos estudados.

Como pode ser observado na TAB. 38 e nos gráficos da FIG. 42, na matriz de água tradada, as incertezas associadas à curva analítica foram as maiores fontes de contribuição para a incerteza combinada dos compostos plastificantes (ftalatos e bisfenol A). Enquanto que para os compostos fenólicos (nonilfenol e pentaclorofenol) as incertezas associadas à recuperação dos analitos foi o fator de maior contribuição para a incerteza global. 
TABELA 38. Contribuição da incerteza de cada grandeza de entrada no cálculo do mensurando no ensaio em água tratada (AT), considerando o ponto médio do intervalo de concentração das curvas analíticas dos compostos estudados.

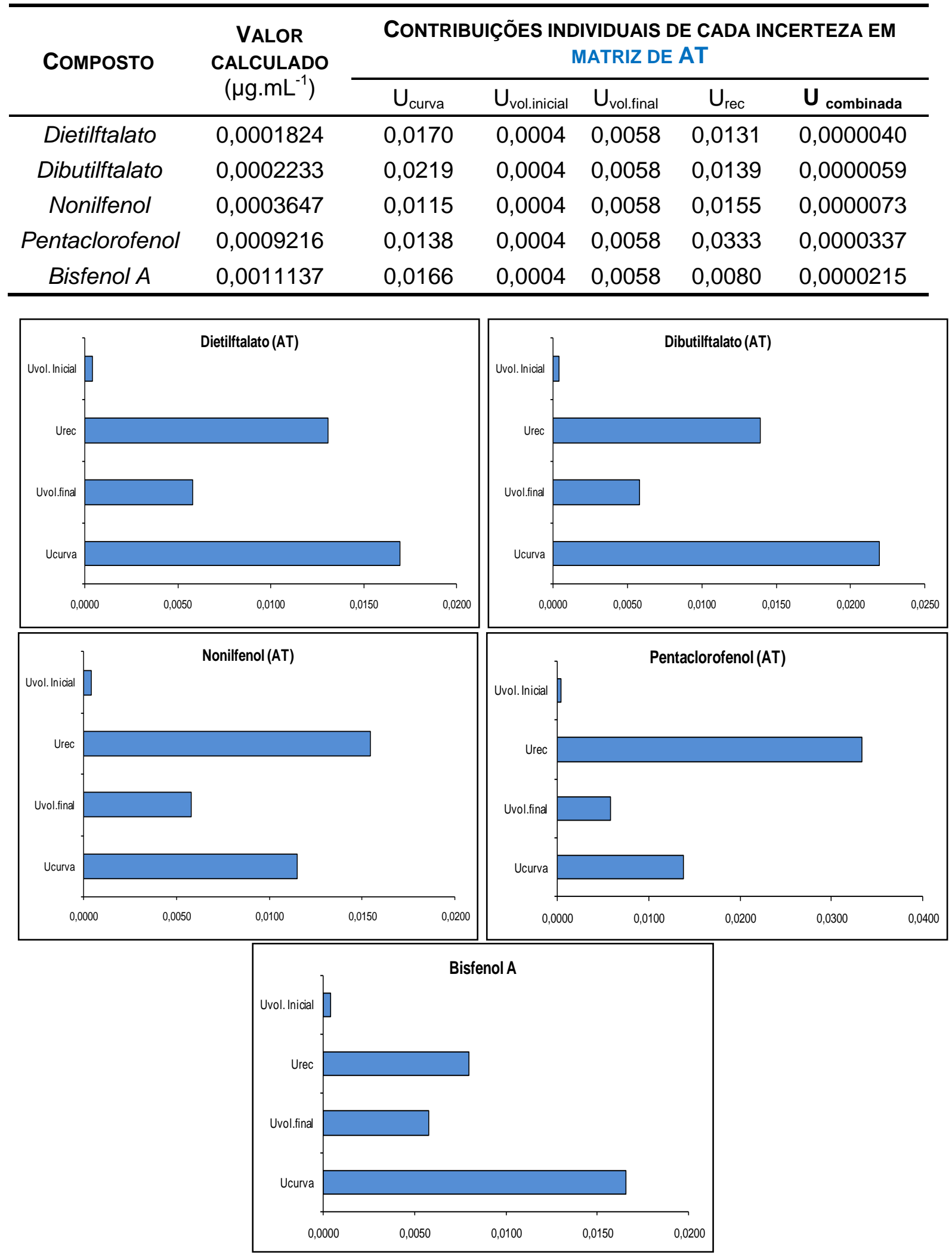

FIGURA 42. Representações gráficas das incertezas individuais envolvidas na análise dos xenoestrógenos na matriz de água tratada (AT). 
TABELA 39. Contribuição da incerteza de cada grandeza de entrada no cálculo do mensurando no ensaio em água bruta $(A B)$, considerando o ponto médio do intervalo de concentração das curvas analíticas dos compostos estudados.

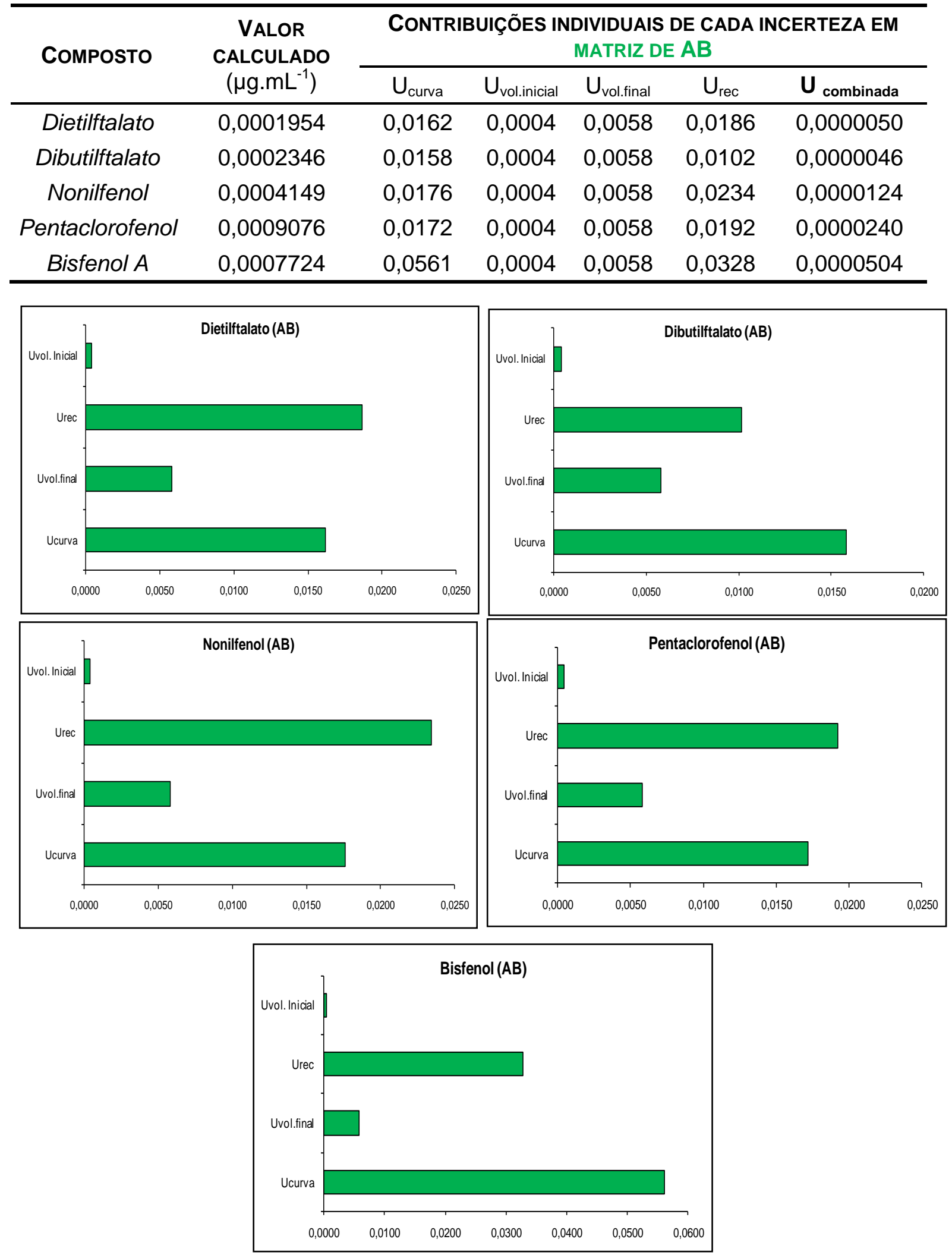

FIGURA 43. Representações gráficas das incertezas individuais envolvidas na análise dos xenoestrógenos na matriz de água bruta $(\mathrm{AB})$. 
Na TAB. 38 e na FIG. 43 são apresentadas as incertezas padronizadas individuais que contribuíram para a incerteza combinada dos mensurandos na matriz de água bruta, e suas representações gráficas. Assim como no ensaio em água tratada, as maiores contribuições para a incerteza global dos analitos foram as associadas às curvas analíticas e às recuperações. Estes resultados são coerentes, uma vez que em ambas estão relacionados às concentrações e a resposta do equipamento.

\subsection{Resultado dos brancos}

Problemas com contaminação de amostras branco têm sido comumente relatados na determinação de xenoestrógenos, especialmente de plastificantes, como os ftalatos e o bisfenol A (Brossa et al., 2003; Serôdio e Nogueira, 2006; Rodil et al., 2009; Diana e Dimitra, 2011).

Segundo Gómez-Hens e Aguilar-Caballos (2003) materiais de laboratório analíticos, como tubos, ponteiras de pipetas, septos de vials cromatográficos, solventes e vidrarias podem ser fontes de contaminação por ftalatos. A contaminação por bisfenol A pode ser proveniente de solventes, vidrarias, tubos de SPE, materiais plásticos usados na coleta ou armazenamentos das amostras, ou ainda de equipamento purificadores de água Milli-Q (Dekant e Völkel, 2008; Ballesteros-Gómez et al., 2009).

Neste estudo, nenhum pico foi encontrado quando realizada a análise da solução de solventes (EtOAc/MeOH, 60:40) - branco do equipamento, no modo SCAN. Entretanto, quando a análise foi feita no modo SIM, mesmo em níveis muito baixos, puderam ser identificados íons característicos nos tempos de retenção correspondentes ao dietilftalato e ao dibutilftalato. Em função de o equipamento ser multiusuário, a contaminação por esses compostos mostrou-se altamente variável, não apresentando reprodutibilidade, o que indicou que a mesma não era proveniente dos solventes empregados na análise.

Para avaliação do procedimento de extração foram realizados brancos com água ultrapura e somente com os solventes envolvidos no processo. Em 
ambos os brancos formam identificados íons característicos dos compostos dietilftalato, dibutilftalato e bisfenol A. Todavia, os brancos com água ultrapura apresentaram uma maior contaminação pelo dibutilftalato. Como a água de alta pureza não participa diretamente do processo de extração, os brancos da extração foram realizados apenas com os solventes.

Embora detectados, a contaminação pelos compostos não pode ser quantificada pelo baixo sinal apresentado, porém, para quantificação das amostras a contaminação pelos compostos mencionados foi descontada.

\subsection{Avaliação dos Xenoestrógenos nas águas do rio Paraíba do SUL}

Aplicando-se a metodologia validada nas amostras de água tratada e bruta provenientes das quatro ETAs situadas no rio Paraíba do Sul foi possível realizar a avaliação da qualidade da água de captação e de distribuição.

Foi analisado um total de 24 amostras coletadas em três meses distintos do ano de 2010, que abrangeram os períodos de seca (junho e setembro) e de chuva (novembro), conforme FIG. 17 apresentada no capítulo 5. Os resultados apresentados nas TAB. 40 a 42 são referentes à média de três análises mais as incertezas associadas. No caso de falso positivo ou negativo, foram realizadas adições padrão a fim de confirmar os resultados. 
TABELA 40. Resultados das análises da coleta de junho para as amostras de água tratada e água bruta dos quatro municípios da região do rio Paraíba do Sul.

\begin{tabular}{|c|c|c|c|c|}
\hline \multicolumn{5}{|c|}{$1^{\circ}$ COLETA (JUNHO/2010) } \\
\hline \multirow[b]{2}{*}{ COMPOSTO } & \multicolumn{4}{|c|}{ CONCENTRAÇÕES $\left(\mu \mathrm{g} \cdot \mathrm{L}^{-1}\right)$ NAS AMOSTRAS DE ÁGUA TRATADA } \\
\hline & Guararema & $\begin{array}{c}\text { São José dos } \\
\text { Campos }\end{array}$ & Taubaté & Pindamonhangaba \\
\hline Dietilftalato & $<0,023$ & $0,048 \pm 0,003$ & $0,129 \pm 0,016$ & $0,143 \pm 0,008$ \\
\hline Dibutilftalato & $0,081 \pm 0,004$ & $0,090 \pm 0,007$ & $0,229 \pm 0,015$ & $0,154 \pm 0,008$ \\
\hline Nonilfenol & $<0,032$ & $0,035 \pm 0,004$ & $0,042 \pm 0,010$ & $0,043 \pm 0,010$ \\
\hline Pentaclorofenol & $n d^{\mathrm{a}}$ & $n d^{\mathrm{a}}$ & $n d^{\mathrm{a}}$ & $n d^{\mathrm{a}}$ \\
\hline Bisfenol A & $<0,044^{\mathrm{b}}$ & $<0,044^{\mathrm{b}}$ & $<0,044^{b}$ & $<0,044^{b}$ \\
\hline \multirow[b]{2}{*}{ CoMposto } & \multicolumn{4}{|c|}{ CONCENTRAÇÕES $\left(\mu \mathrm{g} \cdot \mathrm{L}^{-1}\right)$ NAS AMOSTRAS DE ÁGUA BRUTA } \\
\hline & Guararema & $\begin{array}{c}\text { São José dos } \\
\text { Campos }\end{array}$ & Taubaté & Pindamonhangaba \\
\hline Dietilftalato & $0,087 \pm 0,008$ & $0,238 \pm 0,013$ & $0,439 \pm 0,026$ & $0,332 \pm 0,025$ \\
\hline Dibutilftalato & $0,909 \pm 0,045$ & $0,748 \pm 0,028$ & $1,249 \pm 0,070$ & $0,693 \pm 0,034$ \\
\hline Nonilfenol & $0,233 \pm 0,027$ & $0,846 \pm 0,083$ & $0,618 \pm 0,059$ & $0,638 \pm 0,054$ \\
\hline Pentaclorofenol & $\mathrm{nd}^{\mathrm{a}}$ & $\mathrm{nd}^{\mathrm{a}}$ & $\mathrm{nd}^{\mathrm{a}}$ & $\mathrm{nd}^{\mathrm{a}}$ \\
\hline Bisfenol A & $0,161 \pm 0,028$ & $<0,158^{b}$ & $<0,158^{b}$ & $<0,158^{b}$ \\
\hline
\end{tabular}

TABELA 41. Resultados das análises da coleta de setembro para as amostras de água tratada e água bruta dos quatro municípios da região do rio Paraíba do Sul.

\begin{tabular}{|c|c|c|c|c|}
\hline \multicolumn{5}{|c|}{$2^{\circ}$ COLETA (SETEMBRO/2010) } \\
\hline \multirow[b]{2}{*}{ COMPOSTO } & \multicolumn{4}{|c|}{ CONCENTRAÇÕES $\left(\mu \mathrm{g} \cdot \mathrm{L}^{-1}\right)$ NAS AMOSTRAS DE ÁGUA TRATADA } \\
\hline & Guararema & $\begin{array}{c}\text { São José dos } \\
\text { Campos }\end{array}$ & Taubaté & Pindamonhangaba \\
\hline Dietilftalato & $<0,023^{b}$ & $0,029 \pm 0,003$ & $0,039 \pm 0,003$ & $0,080 \pm 0,006$ \\
\hline Dibutilftalato & $0,175 \pm 0,011$ & $0,188 \pm 0,022$ & $0,070 \pm 0,003$ & $0,454 \pm 0,032$ \\
\hline Nonilfenol & $0,045 \pm 0,005$ & $0,053 \pm 0,004$ & $0,033 \pm 0,004$ & $0,063 \pm 0,004$ \\
\hline Pentaclorofenol & $<0,053^{b}$ & $0,058 \pm 0,004$ & $<0,053^{b}$ & $<0,053^{b}$ \\
\hline Bisfenol A & $<0,044^{b}$ & $<0,044^{\mathrm{b}}$ & $<0,044^{\mathrm{b}}$ & $<0,044^{\mathrm{b}}$ \\
\hline \multirow[b]{2}{*}{ CoMPOSTO } & \multicolumn{4}{|c|}{ CONCENTRAÇÕES $\left(\mu \mathrm{g} \cdot \mathrm{L}^{-1}\right)$ NAS AMOSTRAS DE ÁGUA BRUTA } \\
\hline & Guararema & $\begin{array}{c}\text { São José dos } \\
\text { Campos }\end{array}$ & Taubaté & Pindamonhangaba \\
\hline Dietilftalato & $0,031 \pm 0,005$ & $0,095 \pm 0,005$ & $0,141 \pm 0,018$ & $0,086 \pm 0,010$ \\
\hline Dibutilftalato & $0,891 \pm 0,073$ & $0,595 \pm 0,035$ & $0,871 \pm 0,108$ & $0,282 \pm 0,011$ \\
\hline Nonilfenol & $0,096 \pm 0,015$ & $0,750 \pm 0,081$ & $0,431 \pm 0,024$ & $0,403 \pm 0,029$ \\
\hline Pentaclorofenol & $<0,114$ & $n d^{a}$ & $n d^{a}$ & $n d^{a}$ \\
\hline Bisfenol A & $<0,158^{\mathrm{b}}$ & $<0,158^{\mathrm{b}}$ & $<0,158^{b}$ & $<0,158^{b}$ \\
\hline
\end{tabular}


TABELA 42. Resultados das análises da coleta de novembro para as amostras de água tratada e água bruta dos quatro municípios da região do rio Paraíba do Sul.

\begin{tabular}{|c|c|c|c|c|}
\hline \multicolumn{5}{|c|}{$3^{\circ}$ COLETA (NovEMBRo/2010) } \\
\hline \multirow[b]{2}{*}{ COMPOSTO } & \multicolumn{4}{|c|}{ CONCENTRAÇÕES $\left(\mu \mathrm{g} \cdot \mathrm{L}^{-1}\right)$ NAS AMOSTRAS DE ÁGUA TRATADA } \\
\hline & Guararema & $\begin{array}{c}\text { São José dos } \\
\text { Campos }\end{array}$ & Taubaté & Pindamonhangaba \\
\hline Dietilftalato & $<0,023^{b}$ & $0,028 \pm 0,001$ & $0,024 \pm 0,002$ & $0,024 \pm 0,001$ \\
\hline Dibutilftalato & $0,105 \pm 0,012$ & $0,187 \pm 0,025$ & $0,093 \pm 0,007$ & $0,132 \pm 0,007$ \\
\hline Nonilfenol & $<0,032^{b}$ & $<0,032^{b}$ & $<0,032^{b}$ & $<0,032^{b}$ \\
\hline Pentaclorofenol & $<0,053^{\mathrm{b}}$ & $<0,053^{b}$ & $<0,053^{b}$ & $<0,053^{b}$ \\
\hline Bisfenol A & $<0,044^{\mathrm{b}}$ & $<0,044^{\mathrm{b}}$ & $<0,044^{\mathrm{b}}$ & $<0,044^{\mathrm{b}}$ \\
\hline \multirow[b]{2}{*}{ COMPOSTO } & \multicolumn{4}{|c|}{ CONCENTRAÇÕES $\left(\mu \mathrm{g} \cdot \mathrm{L}^{-1}\right)$ NAS AMOSTRAS DE ÁGUA BRUTA } \\
\hline & Guararema & $\begin{array}{c}\text { São José dos } \\
\text { Campos }\end{array}$ & Taubaté & Pindamonhangaba \\
\hline Dietilftalato & $0,031 \pm 0,002$ & $0,049 \pm 0,005$ & $0,037 \pm 0,005$ & $0,055 \pm 0,005$ \\
\hline Dibutilftalato & $0,256 \pm 0,036$ & $0,635 \pm 0,041$ & $0,540 \pm 0,047$ & $0,564 \pm 0,040$ \\
\hline Nonilfenol & $0,068 \pm 0,008$ & $0,283 \pm 0,038$ & $0,144 \pm 0,012$ & $0,218 \pm 0,028$ \\
\hline Pentaclorofenol & $n d^{a}$ & $n d^{a}$ & $n d^{a}$ & $n d^{a}$ \\
\hline Bisfenol A & $<0,158^{b}$ & $<0,158^{b}$ & $<0,158^{b}$ & $<0,158^{\mathrm{b}}$ \\
\hline
\end{tabular}

Como pode ser observado nas TAB. 40 a 42 todos os compostos foram detectados nas amostras de água tratada ou água bruta em um dos três períodos de amostragem. Embora apenas quatro, dos seis compostos estudados, tenham sido detectados na primeira coleta em ambas as amostras, as concentrações mais altas foram observadas nesse mês, e podem ser visualizadas nos gráficos do dietilftalato apresentados na FIG. 44. Este resultado pode ser atribuído à menor precipitação do período, uma vez que o mês de junho abrangeu o período seco.

Dentre os municípios investigados, não houve tendência de um que apresentasse os maiores níveis de contaminação, entretanto, a cidade de Guararema mostrou ter suas águas menos impactadas pela presença desses micropoluentes, talvez em função deste município apresentar o menor número de habitantes e índice de industrialização. 

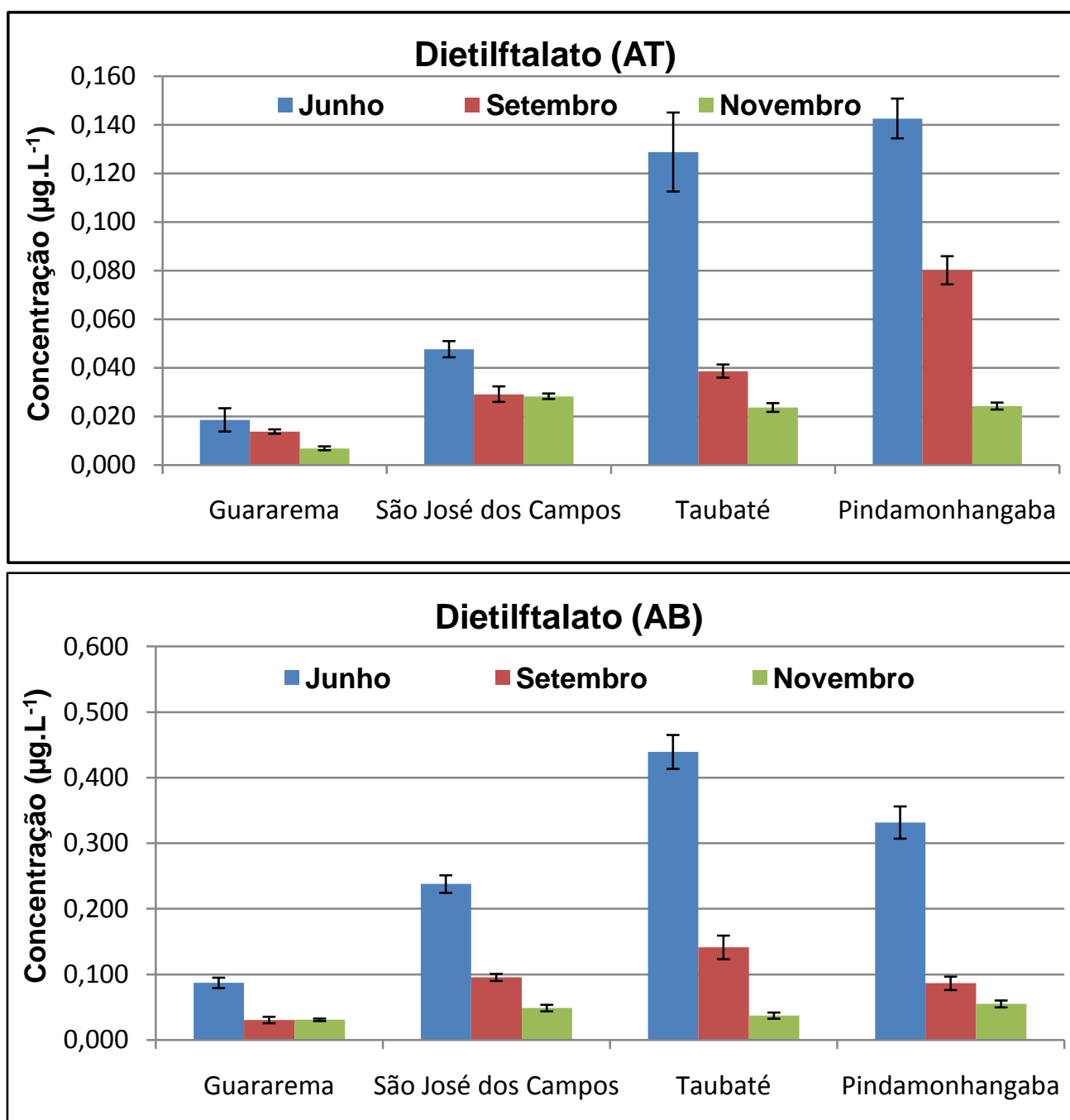

FIGURA 44. Concentrações do composto dietilftalato nos três meses de coleta nas amostras de água tratada (a) e água bruta (b).

Os ftalatos foram os que apresentaram maior frequência, sendo quantificados em 100\% ( $n=24)$ das amostras de água superficial e de distribuição. As concentrações para o dietilftalato variaram entre $<0,023$ e $0,143 \mu \mathrm{g} . \mathrm{L}^{-1}$ nas amostras de água tratada, e de 0,031 a 0,439 $\mu \mathrm{g} \cdot \mathrm{L}^{-1}$ nas amostras de água bruta. Para o dibutilftalato as concentrações encontradas nas águas tratadas do Paraíba do Sul foram mensuradas entre 0,070 e 0,454 $\mu \mathrm{g} \cdot \mathrm{L}^{-1}$, e nas águas brutas variaram de $0,256 \mu \mathrm{g} \cdot \mathrm{L}^{-1}$ a $1,249 \mu \mathrm{g} \cdot \mathrm{L}^{-1}$.

Essas concentrações são inferiores às encontradas por Ghiselli (2006) nas águas superficiais e de abastecimento na região de Campinas, onde os níveis de DEP e DBP na água tratada variaram, respectivamente, entre $0,13 \mu \mathrm{g} \cdot \mathrm{L}^{-1} \mathrm{e}$ $0,23 \mu \mathrm{g} \cdot \mathrm{L}^{-1}$ e de $0,33 \mu \mathrm{g} \cdot \mathrm{L}^{-1}$ a $1,75 \mu \mathrm{g} \cdot \mathrm{L}^{-1}$. Neste mesmo estudo, na água bruta o 
DEP esteve entre 0,22 a $3,2 \mu \mathrm{g} \cdot \mathrm{L}^{-1}$, e o DBP variou de 0,39 a $2,4 \mu \mathrm{g} \cdot \mathrm{L}^{-1}$. No estudo conduzido por Raimundo (2007), o DBP foi detectado em $94 \%$ das amostras provenientes da bacia do rio Atibaia, todavia, em concentrações superiores, com média de $9,34 \mu \mathrm{g} \cdot \mathrm{L}^{-1}$. Já o DEP não foi detectado em níveis superiores ao limite de quantificação $\left(0,03 \mu \mathrm{g} \cdot \mathrm{L}^{-1}\right)$ nas 34 amostras de águas superficiais.

Embora, a legislação brasileira não contemple estes compostos, se compararmos com o valor mais restritivo para substâncias orgânicas, que é de $0,018 \mu \mathrm{g} \cdot \mathrm{L}^{-1}$ para águas doces classe 1 , estabelecido pela Resolução CONAMA $n^{\circ} 357$ (Brasil, 2005), as concentrações encontradas para estes ftalatos estão acima deste limite. No Canadá, a concentração de $19 \mu \mathrm{g} \cdot \mathrm{L}^{-1}$ é o valor guia adotado para o DBP em águas superficiais, dessa forma, as concentração encontradas no rio Paraíba do Sul para este composto foram inferiores.

Os isômeros do nonilfenol também foram detectados em todas as amostras analisadas. Na água potável, as concentrações médias de NP nos municípios estudados, nos meses de junho e setembro foram, respectivamente, de 0,032 e 0,049 $\mu \mathrm{g} \cdot \mathrm{L}^{-1}$, na terceira coleta, em novembro, as concentrações ficaram abaixo do limite de quantificação $\left(0,032 \mu \mathrm{g} \cdot \mathrm{L}^{-1}\right)$. Os níveis médios encontrados nas águas superficiais das cidades avaliadas foram de $0,584 \mu \mathrm{g} \cdot \mathrm{L}^{-1} \mathrm{e}$ $0,420 \mu \mathrm{g} \cdot \mathrm{L}^{-1}$ na primeira e segunda coletas, e de $0,178 \mu \mathrm{g} \cdot \mathrm{L}^{-1}$ no mês de novembro, sendo o valor de $0,846 \mu \mathrm{g} \cdot \mathrm{L}^{-1}$ a maior concentração avaliada.

Moreira (2008) relata a ocorrência de isômeros de NP em amostras de água superficiais de mananciais da região metropolitana de Belo Horizonte, assim como em amostras de água filtrada (anteriormente a etapa de cloração da água potável), em concentrações similares às encontradas por este estudo. Como consta na TAB. 2 do capítulo 3 desta dissertação, na legislação internacional o valor guia mais restritivo adotado para o nonilfenol e seus etoxilados em água superficiais é de $1 \mu \mathrm{g} . \mathrm{L}^{-1}$ (Canada, 2002), como pode-se observar os níveis de contaminação encontrados no rio Paraíba do Sul para o NP estão abaixo deste limiar. 
O pentaclorofenol foi detectado nas amostras de água tratada nos meses de setembro e novembro, contudo abaixo do limite de quantificação $\left(0,053 \mu \mathrm{g} \cdot \mathrm{L}^{-1}\right)$. A identificação do PCP nas amostras de água tratada nestes meses pode estar vinculada à adição do preservante tiossulfato de sódio, que atua como oxidante do cloro livre, diferente da coleta de junho à qual não foi adicionado. Já nas amostras de água bruta, este pesticida foi detectado em apenas uma amostra. Este resultado pode indicar a interferência da matriz de água bruta na detecção deste composto ou, avaliando os resultados de água tratada, a formação do mesmo durante o processo de tratamento da água, pela cloração de fenóis presentes na água bruta (IPCS, 1987).

Poucos são os estudos que investigam a presença do PCP em amostras ambientais no Brasil. Komatsu e Vaz (2004) não encontraram este pesticida em amostra de água bruta coletada em Cananéia, SP. A análise multiresidual de substâncias consideradas prioritárias pela União Européia, entre elas PCP, não detectou este composto em águas superficiais da França (Barrek et al., 2009). O valor máximo permissível deste composto para águas de abastecimento estabelecido pela Portaria $n^{\circ} 518 / 04$ (Brasil, 2005b) é de $9 \mu \mathrm{g} \cdot \mathrm{L}^{-1}$, já o CONAMA (Brasil, 2005) estipula valores mais rígidos para este composto em águas doce classe 1 , sendo o valor máximo de $3 \mu \mathrm{g} \cdot \mathrm{L}^{-1}$. Na União Européia, o valor de $0,1 \mu \mathrm{g} \cdot \mathrm{L}^{-1}$ é aceito como a concentração máxima individual de PCP ou de outro pesticida na água potável. Este estudo demonstrou que a contaminação das águas tratadas não ultrapassou esta concentração.

Assim, como os ftalatos e o nonilfenol, o bisfenol A foi detectado em $100 \%$ das amostras analisadas $(n=24)$, entretanto, ficou abaixo da concentração (LQ) de $0,044 \mu \mathrm{g} \cdot \mathrm{L}^{-1}$ nas amostra de água potável. Nas águas brutas apenas a amostra de Guararema no mês de junho apresentou concentração de 0,16 $\mu \mathrm{g} \cdot \mathrm{L}^{-1}$, acima do limite de quantificação, todas as demais resultaram em valores abaixo do $L Q$ de $0,15 \mu \mathrm{g} \cdot \mathrm{L}^{-1}$.

Contaminação superior por BPA foi relatada por Leandro (2006) nas águas captadas no processo de entrada e saída de uma ETA localizada na cidade de Araraquara (SP), onde as concentrações máximas foram de 7,3 e 18,8 $\mu \mathrm{g} \cdot \mathrm{L}^{-1}$ 
nas amostras de água tratada e bruta, respectivamente. Nas águas do rio Atibaia, Sodré (2010) mensurou este xenoestrógenos em concentrações entre 25 e $84 \mathrm{ng} \cdot \mathrm{L}^{-1}$. O BPA, até o momento, não é regulamentado em águas superficiais ou de abastecimento nas leis nacionais ou internacionais.

Embora a metodologia desenvolvida não esteja sendo considerada para quantificação de amostras devido ao fato de a recuperação ser muito baixa, o benzo[a]pireno, foi o que apresentou menor frequência, com resultados positivos em todas as amostras de água tratada da segunda coleta (setembro), e nas amostras de água bruta de Guararema e Pindamonhangaba desta mesma coleta, porém todas abaixo do limite de quantificação. São escassas as pesquisas de disruptores endócrinos que investigam a contaminação de águas por $\mathrm{B}[\mathrm{a}] \mathrm{P}$. Barrek e coautores (2009) constataram a contaminação de B[a]P em $87 \%$ das amostras de águas superficiais da França, porém em concentrações inferiores a $20 \%$ do limiar estabelecido pela legislação européia. Os valores encontrados nas águas de abastecimento da região do Vale do Paraíba estão abaixo do recomendado pela Portaria $n^{\circ} 518 / 04$ (Brasil, 2005b), que regulamenta a concentração de $0,7 \mu \mathrm{g} \cdot \mathrm{L}^{-1}$ para água potável.

A presença desses disruptores provenientes de atividades antrópicas nas águas do rio Paraíba do Sul, principalmente dos plastificantes e do nonilfenol, pode ser atribuída à industrialização da referida região e à descarga de efluentes domésticos e industriais. Conforme comentado anteriormente, as concentrações avaliadas por este estudo são inferiores às encontradas por outras pesquisas em bacias hidrográficas da região sudeste (Ghiselli, 2006; Leandro, 2006; Raimundo, 2007) e por estudos de águas superficiais em Portugal (Azevedo et al., 2001) e na China (Jin et al., 2004). Contudo, a contaminação da água potável por ftalatos identificada nesta pesquisa foi superior aos valores estabelecidos na água de distribuição em Portugal (Serôdio e Nogueira, 2006) e na Espanha (Casajuana e Lacorte, 2003).

Pelos dados apresentados nas TAB. 40 a 42 e na FIG. 45 notam-se menores concentrações dos xenoestrógenos nas amostras de água potável em todos os meses avaliados, indicando que embora o tratamento da água não 
consiga remover os compostos em sua totalidade, é capaz de reduzir significativamente os níveis de contaminação da água distribuída à população.

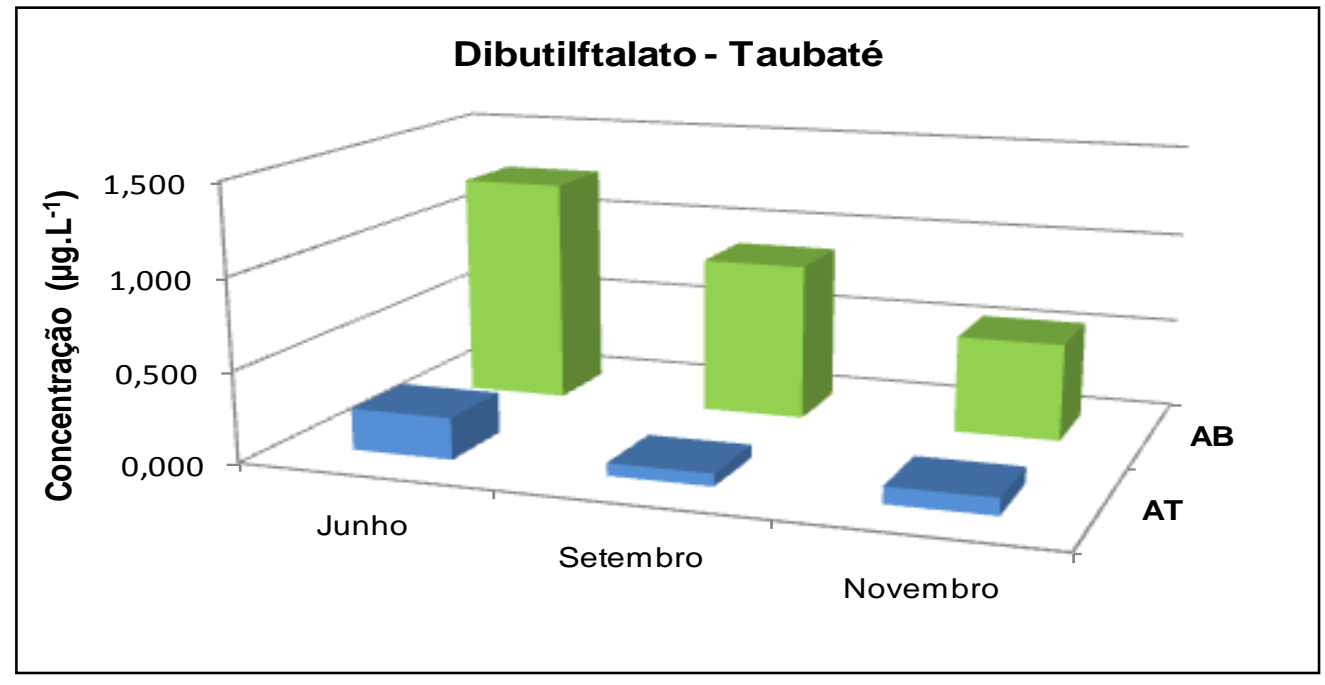

(a)

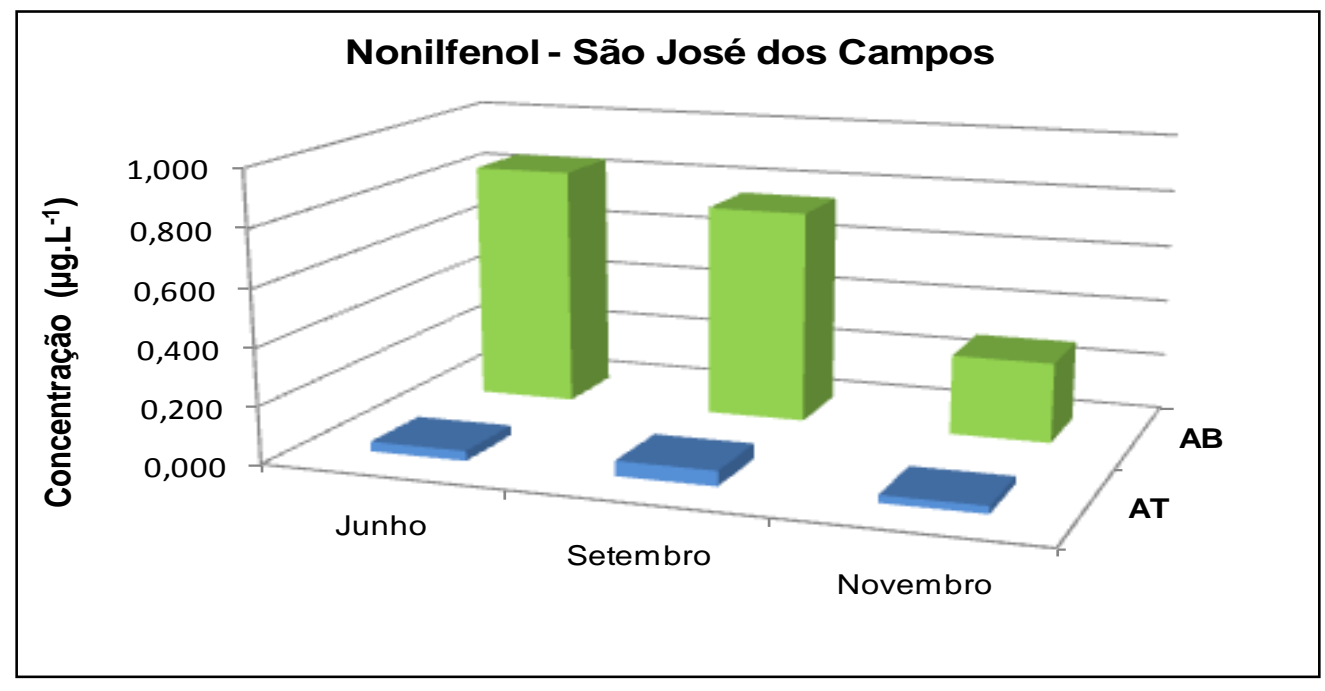

FIGURA 45. Concentrações dos compostos dibutilftalato e nonilfenol nas amostras de água tratada $(A T)$ e água bruta ( $A B)$ nos municípios de Taubaté (a) e São José dos Campos (b).

\subsection{OUTRAS APLICAÇÕES DA METODOLOGIA}

\subsubsection{Avaliação das amostras de água mineral}

As análises das amostras de água mineral de garrafas PET (polietileno tereftalato) demonstraram não haver contaminação pelos plastificantes investigados, tanto na amostra extraída imediatamente após a compra, quanto na que foi armazenada e posteriormente analisada. Estes resultados indicam que a água comercializada pela marca avaliada não apresenta contaminação na fonte 
mineral utilizada, e que nas condições de armazenamento a que foi submetida a amostra, os compostos plásticos constituintes da embalagem não foram lixiviados para a água mineral.

\subsubsection{Avaliação da resistência das mamadeiras ao aquecimento}

A presença do composto bisfenol $A$, que poderia ter migrado do plástico policarbonato da mamadeira, não foi observada nas amostras submetidas ao aquecimento em forno micro-ondas, nem mesmo após os vários ciclos de aquecimento, demonstrando que a marca é de boa qualidade e que a matériaprima utilizada na síntese do policarbonato não foi lixiviada. Todavia, apesar deste resultado, não é recomendável submeter a mamadeira ao aquecimento diretamente em forno micro-ondas, uma vez que os diferentes gradientes de temperatura podem causar queimaduras na criança. Salienta-se ainda que apenas uma marca disponível no mercado foi analisada, porém outras marcas de qualidade inferior podem apresentar migração do bisfenol A. 


\section{CONCLUSÕES}

1. A metodologia aqui proposta mostrou ser adequada para a determinação de cinco dos seis disruptores endócrinos de origem industrial em amostras de água tratada e bruta na faixa de concentração de $\mu \mathrm{g} \cdot \mathrm{L}^{-1}$, fato este que só foi possível pela preparação das amostras pela técnica de extração em fase sólida (SPE) e pelo uso do equipamento de cromatografia gasosa com detecção por espectrometria de massas (GC/MS), que apresenta elevada seletividade e sensibilidade adequada.

2. Para o HPA benzo[a]pireno, seria interessante a adaptação da metodologia visando obter melhores resultados para este composto.

3. O processo de validação da metodologia analítica forneceu confiabilidade estatística aos dados, confirmando a sensibilidade e a seletividade do método, além da boa linearidade nas faixas de trabalho consideradas. Os resultados de áreas são diretamente proporcionais às concentrações dos analitos dentro de uma variação estatisticamente aceitável.

4. O método mostrou-se preciso e exato para todos os compostos nas duas matrizes avaliadas. Os limites de deteç̧ão e quantificação alcançados, após a concentração de $1 \mathrm{~L}$ de amostra, são coerentes com os limites necessários para a análise de amostras ambientais, nas quais os analitos se encontram em níveis traço.

5. Exceto para o benzo[a]pireno, as recuperações obtidas para os compostos nos três níveis de concentração estudados e nas matrizes de água tratada e bruta foram satisfatórias, e estão dentro da faixa recomendada pela literatura. 
6. A metodologia é robusta frente a pequenas variações nos parâmetros inicialmente estabelecidos. Apenas a voltagem do detector apresentou influência positiva para todos os compostos e em ambas as matrizes, porém a alteração deste fator não se justifica uma vez que haveria uma significativa redução no sinal analítico. O aumento no fluxo da coluna demonstrou prejudicar a análise dos seis analitos na amostra de água tratada, e de cinco compostos na água bruta. A exceção foi o benzo[a]pireno, que nesta matriz sofre influência positiva pela alteração de todos os fatores.

7. Embora exista uma tendência mundial, na atualidade ainda são poucos os estudos que incluem cálculos de incerteza das medições. Nesta pesquisa, além de agregar valor e confiança aos resultados, estes cálculos demonstraram que as maiores fontes de incerteza são as associadas às curvas analíticas e à recuperação do método.

8. Pela aplicação da metodologia nas amostras de água provenientes do rio Paraíba do Sul foi possível verificar a presença dos seis poluentes estudados em baixas concentrações tanto na água bruta quanto na tratada. Os compostos dietilftalato, dibutilftalato, nonilfenol e bisfenol A foram identificados em $100 \%$ das amostras $(n=24)$ nos períodos avaliados, sendo que em praticamente todas as amostras as concentrações estiveram acima dos limites de quantificação. O pentaclorofenol foi encontrado em $66 \%$ das amostras de água tratada $(n=12)$ e em apenas $8 \%$ das amostras de água bruta $(n=12)$, todavia, abaixo dos limites estabelecidos pelas legislações consultadas. $O$ benzo[a]pireno apresentou menor frequência na água tratada, apresentando resultados positivos em $33 \%$ das amostras $(n=12)$, e em $16 \%$ das águas brutas analisadas ( $n=12)$, porém em todas abaixo do LQ. Estes resultados demonstram que as atividades antrópicas na região influenciam a qualidade da água tanto do recurso hídrico estudado, como a qualidade da água de distribuição, embora o processo de tratamento de água colabore para a diminuição destes contaminantes na água potável. Nota-se que as maiores concentrações foram mensuradas nas águas brutas e no período seco. 


\section{CONSIDERAÇÕES FINAIS}

O presente trabalho, que teve como foco desenvolver, validar e aplicar metodologia analítica para determinação de compostos orgânicos considerados disruptores endócrinos em amostras de água provenientes de Estações de Tratamento de Água - ETAs na região do Vale do Paraíba paulista, contribuirá para o entendimento dos níveis de contaminação por estes micropoluentes de origem antrópica na bacia hidrográfica do rio Paraíba do Sul, auxiliando no plano de gestão de recursos hídricos da região, além de fornecer subsídios aos órgãos governamentais para a reavaliação das leis atuais.

Como sugestão para trabalhos posteriores, recomenda-se a continuação do monitoramento desses xenoestrógenos nesta bacia hidrográfica, e que esta avaliação seja estendida a outras bacias não só da região sudeste do país, mas de outras áreas, onde os trabalhos neste contexto são escassos. A eficiência da ETAs poderia ser avaliada respeitando-se o tempo de retenção hidráulica, o que não ocorreu neste estudo.

Outro fato relevante em pesquisas futuras seria a utilização de técnicas analíticas mais modernas, onde menores limites pudessem ser alcançados, já que ainda não se conhece os níveis seguros desses micropoluentes no meio ambiente, o que torna necessário que os mesmos sejam detectados em concentrações cada vez mais baixas.

Propõem-se ainda a aplicação de ensaios toxicológicos em amostras da região a fim de avaliar se os níveis dos poluentes encontrados, mesmo em baixas concentrações individuais, quando em sinergia causam efeitos adversos aos organismos expostos. 


\section{APÊNDICE 1}

Resultados das incertezas parciais envolvidas no cálculo de Incertezas para os compostos com recuperação acima de $70 \%$.

\section{CÁLCULO DE INCERTEZAS PARA O DIETILFTALATO (DEP)}

1. Incerteza da preparação da solução padrão estoque

Grandezas de entrada: pureza do padrão e volume final da solução estoque.

Componentes de incertezas

$$
\begin{aligned}
& u(P)=0,0017321 \mu \mathrm{g} \cdot \mathrm{mL}^{-1} \\
& \mathrm{u}(\mathrm{V})=0,0151438 \mu \mathrm{g} \cdot \mathrm{mL}^{-1} \\
& \text { Incerteza combinada }
\end{aligned}
$$

$$
\mathrm{u}_{\mathrm{c}}\left(D E P_{\text {sol.padrão }}\right)=0,00030 \mu \mathrm{g} \cdot \mathrm{mL}^{-1} \text { (solução } 20 \mathrm{mg} \cdot \mathrm{mL}^{-1} \text { ) }
$$

2. Incerteza da preparação da solução de trabalho intermediária

Grandezas de entrada: incerteza da solução estoque, volume pipetado da solução estoque individual para preparação da solução mista de trabalho e volume final da solução mista de trabalho.

Componentes de incertezas

$$
\begin{aligned}
& \mathrm{u}\left(\mathrm{C}_{\text {sol. estoque }}\right)=0,00030485 \mu \mathrm{g} \cdot \mathrm{mL}^{-1} \\
& \mathrm{u}\left(\mathrm{V}_{\text {i_estoque }}\right)=0,000500918 \mu \mathrm{g} \cdot \mathrm{mL}^{-1} \\
& \text { calibração }=0,000433013 \\
& \text { repe }=0,00025 \\
& \Delta \mathrm{t}=3,03109 \mathrm{E}-05 \\
& \mathrm{u}\left(\mathrm{V}_{\text {final }}\right)=0,012033426 \mu \mathrm{g} \cdot \mathrm{mL}^{-1} \\
& \text { calibração }=0,011547005 \\
& \text { repe }=0,003162278 \\
& \Delta \mathrm{t}=0,001212436
\end{aligned}
$$

\section{Incerteza combinada}

$\mathrm{u}_{\mathrm{c}}\left(\mathrm{DEP} \mathrm{P}_{\text {sol_intermediária }}\right)=1,165118674 \mu \mathrm{g} \cdot \mathrm{mL}^{-1}\left(\right.$ solução $\left.500 \mu \mathrm{g} \cdot \mathrm{mL}^{-1}\right)$ 
3. Incerteza da preparação da solução de trabalho 1

Grandezas de entrada: incerteza da solução estoque, volume pipetado da solução de trabalho intermediária para preparação da solução mista de trabalho e volume final da solução mista de trabalho.

Componentes de incertezas

$$
\begin{aligned}
& \mathrm{u}\left(\mathrm{C}_{\text {sol. estoque }}\right)=1,165118674 \mu \mathrm{g} \cdot \mathrm{mL}^{-1} \\
& \mathrm{u}\left(\mathrm{V}_{\text {i_estoque }}\right)=0,000200367 \mu \mathrm{g} \cdot \mathrm{mL}^{-1} \\
& \text { calibração }=0,000173205 \\
& \text { repe }=0,0001 \\
& \Delta \mathrm{t}=1,21244 \mathrm{E}-05 \\
& \mathrm{u}\left(\mathrm{V}_{\text {final }}\right)=0,012033426 \mu \mathrm{g} \cdot \mathrm{mL}^{-1} \\
& \text { calibração = 0,011547005 } \\
& \text { repe }=0,003162278 \\
& \Delta \mathrm{t}=0,001212436
\end{aligned}
$$

4. Incerteza da preparação da solução de trabalho 2

Grandezas de entrada: incerteza da solução estoque, volume pipetado da solução de trabalho 1 para preparação da solução mista de trabalho e volume final da solução mista de trabalho.

Componentes de incertezas

$$
\begin{aligned}
& \mathrm{u}\left(\mathrm{C}_{\text {sol. estoque }}\right)= 0,016477266 \mu \mathrm{g} \cdot \mathrm{mL}^{-1} \\
& \mathrm{u}\left(\mathrm{V}_{\text {i_estoque }}\right)= 0,001001836 \mu \mathrm{g} \cdot \mathrm{mL}^{-1} \\
& \text { calibração }=0,000866025 \\
& \text { repe }=0,0005 \\
& \Delta \mathrm{t}=6,06218 \mathrm{E}-05 \\
& \mathrm{u}\left(\mathrm{V}_{\text {final }}\right)=0,008824256 \mu \mathrm{g} \cdot \mathrm{mL}^{-1} \\
& \text { calibração }=0,008660254 \\
& \text { repe }=0,001581139 \\
& \Delta t=0,000606218
\end{aligned}
$$

\section{Incerteza combinada}

$\mathrm{u}_{\mathrm{c}}\left(\mathrm{DEP} \mathrm{P}_{\text {sol_trabalho2}}\right)=0,002118177 \mu \mathrm{g} \cdot \mathrm{mL}^{-1}$ (solução $0,5 \mu \mathrm{g} \cdot \mathrm{mL}^{-1}$ )

5. Incerteza da preparação das soluções de calibração para a curva analítica

Grandezas de entrada: incerteza da solução de trabalho, volume pipetado da solução de trabalho e volume dos balões usados para diluição das soluções.

Incerteza volume pipetado para cada solução da curva

$$
\begin{array}{r}
\mathrm{u}(\mathrm{V} 1 \text { _sol.trabalho })=0,000867489 \mu \mathrm{g} \cdot \mathrm{mL}^{-1} \\
\text { calibração }=0,000866025
\end{array}
$$




$$
\begin{aligned}
& \text { repe }=0,00005 \\
& \Delta \mathrm{t}=6,06218 \mathrm{E}-06 \\
& \mathrm{u}(\mathrm{V} 2 \text { _sol.trabalho })=0,001734978 \mu \mathrm{g} \cdot \mathrm{mL}^{-1} \\
& \text { calibração }=0,001732051 \\
& \text { repe }=0,0001 \\
& \Delta \mathrm{t}=1,21244 \mathrm{E}-05 \\
& \mathrm{u}(\text { V3_sol.trabalho })=0,000234429 \mu \mathrm{g} \cdot \mathrm{mL}^{-1} \\
& \text { calibração }=0,00023094 \\
& \text { repe }=0,00004 \\
& \Delta \mathrm{t}=4,84974 \mathrm{E}-06 \\
& \mathrm{u}(\text { V4_sol.trabalho })=0,000644679 \mu \mathrm{g} \cdot \mathrm{mL}^{-1} \\
& \text { calibração }=0,000635085 \\
& \text { repe }=0,00011 \\
& \Delta \mathrm{t}=1,33368 \mathrm{E}-05 \\
& \mathrm{u}(\text { V5_sol.trabalho })=0,001172144 \mu \mathrm{g} \cdot \mathrm{mL}^{-1} \\
& \text { calibração }=0,001154701 \\
& \text { repe }=0,0002 \\
& \Delta \mathrm{t}=2,42487 \mathrm{E}-05 \\
& \mathrm{u}\left(\mathrm{V} \_1 \mathrm{~mL}\right)=0,005774776 \mu \mathrm{g} \cdot \mathrm{mL}^{-1} \\
& \text { calibração }=0,005773503 \\
& \text { repe }=0 \\
& \Delta \mathrm{t}=0,000121244
\end{aligned}
$$

Incerteza combinada para cada uma das soluções da curva

$\mathrm{u}_{\mathrm{c}}\left(\mathrm{DEP} \_\mathrm{C} 1_{\text {sol_curva }}\right)=0,000459476 \mu \mathrm{g} \cdot \mathrm{mL}^{-1}$ (solução $0,025 \mu \mathrm{g} \cdot \mathrm{mL}^{-1}$ )

$\mathrm{u}_{\mathrm{c}}\left(\mathrm{DEP} \_\mathrm{C} 2_{\text {sol_curva }}\right)=0,000918953 \mu \mathrm{g} \cdot \mathrm{mL}^{-1}$ (solução $0,05 \mu \mathrm{g} \cdot \mathrm{mL}^{-1}$ )

$\mathrm{u}_{\mathrm{c}}\left(\mathrm{DEP} \_\mathrm{C} 3_{\text {sol_curva }}\right)=0,001705526 \mu \mathrm{g} \cdot \mathrm{mL}^{-1}$ (solução $0,20 \mu \mathrm{g} \cdot \mathrm{mL}^{-1}$ )

$\mathrm{u}_{\mathrm{c}}\left(\mathrm{DEP} \_\mathrm{C} 4_{\text {sol_curva }}\right)=0,004690198 \mu \mathrm{g} \cdot \mathrm{mL}^{-1}$ (solução $0,55 \mu \mathrm{g} \cdot \mathrm{mL}^{-1}$ )

$\mathrm{u}_{\mathrm{c}}\left(\mathrm{DEP} \_\mathrm{C} 5_{\text {sol_curva }}\right)=0,008527632 \mu \mathrm{g} \cdot \mathrm{mL}^{-1}$ (solução $1,00 \mu \mathrm{g} \cdot \mathrm{mL}^{-1}$ )

Os cálculos até aqui apresentados podem ser aplicados às duas matrizes (água bruta e tratada), uma vez que as grandezas de entrada não envolvem as respostas das amostras. A seguir são descritas individualmente as incertezas calculadas para as curvas analíticas e a recuperação de cada matriz.

\section{$\Rightarrow \quad$ MATRIZ ÁGUA TRATADA}

6. Incerteza da curva analítica

Grandezas de entrada: área da amostras, área do branco, soluções da curva (C1 a C5), áreas referentes às soluções da curva.

\section{Incerteza combinada da curva analítica}

$$
\mathrm{u}_{\mathrm{c}}\left(\mathrm{DEP}_{\text {curva_analitica }}\right)=0,0033 \mu \mathrm{g} \cdot \mathrm{mL}^{-1}
$$


7. Incerteza da recuperação

Grandezas de entrada: concentração da solução padrão e resultado da concentração encontrada.

$$
\begin{aligned}
& \text { Incerteza combinada da recuperação } \\
& \begin{aligned}
& \mathrm{u}_{\mathrm{c}}(\mathrm{DEP} \text { recuperação })=0,0137776 \mu \mathrm{g} \cdot \mathrm{mL}^{-1} \\
& \mathrm{u}\left(\mathrm{C}_{\text {real }}\right)=0,006423301 \mu \mathrm{g} \cdot \mathrm{mL}^{-1} \\
& \mathrm{u}\left(\mathrm{C}_{\text {encontrada }}\right)=0,011417491 \mu \mathrm{g} \cdot \mathrm{mL}^{-1}
\end{aligned}
\end{aligned}
$$

\section{$\Rightarrow$ MATRIZ ÁGUA BRUTA}

6. Incerteza da curva analítica

Grandezas de entrada: área da amostras, área do branco, soluções da curva (C1 a C5), áreas referentes às soluções da curva.

$$
\begin{aligned}
& \text { Incerteza combinada da curva analítica } \\
& \mathrm{u}_{\mathrm{c}}\left(\mathrm{DEP}_{\text {curva_analitica }}\right)=0,0032 \mu \mathrm{g} \cdot \mathrm{mL}^{-1}
\end{aligned}
$$

7. Incerteza da recuperação

Grandezas de entrada: concentração da solução padrão e resultado da concentração encontrada.

$$
\begin{aligned}
& \text { Incerteza combinada da recuperação } \\
& \begin{aligned}
& \mathrm{u}_{\mathrm{c}}(\mathrm{DEP} \text { recuperação })=0,0190436 \mu \mathrm{g} \cdot \mathrm{mL}^{-1} \\
& \mathrm{u}\left(\mathrm{C}_{\text {real }}\right)=0,006423301 \mu \mathrm{g} \cdot \mathrm{mL}^{-1} \\
& \mathrm{u}\left(\mathrm{C}_{\text {encontrada }}\right)=0,017492554 \mu \mathrm{g} \cdot \mathrm{mL}^{-1}
\end{aligned}
\end{aligned}
$$

\section{CÁLCULO DE INCERTEZAS PARA O DIBUTILFTALATO (DBP)}

1. Incerteza da preparação da solução padrão

Grandezas de entrada: pureza do padrão e volume final da solução estoque.

Componentes de incertezas

$$
\begin{aligned}
& \mathrm{u}(\mathrm{P})=0,0075056 \mu \mathrm{g} \cdot \mathrm{mL}^{-1} \\
& \mathrm{u}(\mathrm{V})=0,0151438 \mu \mathrm{g} \cdot \mathrm{mL}^{-1} \\
& \text { Incerteza combinada } \\
& \mathrm{u}_{\mathrm{c}}\left(\mathrm{DBP}_{\text {sol.padrão }}\right)=0,00034 \mu \mathrm{g} \cdot \mathrm{mL}^{-1}
\end{aligned}
$$

2. Incerteza da preparação da solução de trabalho intermediária.

Grandezas de entrada: incerteza da solução estoque, volume pipetado da solução estoque individual para preparação da solução mista de trabalho e volume final da solução mista de trabalho.

Componentes de incertezas

$$
\begin{aligned}
& \mathrm{u}\left(\mathrm{C}_{\text {sol. estoque }}\right)=0,000338034 \mu \mathrm{g} \cdot \mathrm{mL}^{-1} \\
& \mathrm{u}\left(\mathrm{V}_{\mathrm{i} \text { _estoque }}\right)=0,000500918 \mu \mathrm{g} \cdot \mathrm{mL}^{-1}
\end{aligned}
$$




$$
\begin{gathered}
\text { calibração }=0,000433013 \\
\text { repe }=0,00025 \\
\Delta t=3,03109 \mathrm{E}-05 \\
\mathrm{u}\left(\mathrm{V}_{\text {final }}\right)=0,012033426 \mu \mathrm{g} \cdot \mathrm{mL}^{-1} \\
\text { calibração }=0,011547005 \\
\text { repe }=0,003162278 \\
\Delta t=0,001212436
\end{gathered}
$$

\section{Incerteza combinada}

$\mathrm{u}_{\mathrm{c}}\left(\mathrm{DBP}_{\text {sol_intermediária }}\right)=1,153432429 \mu \mathrm{g} \cdot \mathrm{mL}^{-1}$

3. Incerteza da preparação da solução de trabalho 1

Grandezas de entrada: incerteza da solução estoque, volume pipetado da solução de trabalho intermediária para preparação da solução mista de trabalho e volume final da solução mista de trabalho.

Componentes de incertezas

$$
\begin{aligned}
& \mathrm{u}\left(\mathrm{C}_{\text {sol. estoque }}\right)=1,153432429 \mu \mathrm{g} \cdot \mathrm{mL}^{-1} \\
& \mathrm{u}\left(\mathrm{V}_{\text {i_estoque }}\right)=0,000200367 \mu \mathrm{g} \cdot \mathrm{mL}^{-1} \\
& \text { calibração }=0,000173205 \\
& \text { repe }=0,0001 \\
& \Delta \mathrm{t}=1,21244 \mathrm{E}-05 \\
& \mathrm{u}\left(\mathrm{V}_{\text {final }}\right)=0,012033426 \mu \mathrm{g} \cdot \mathrm{mL}^{-1} \\
& \text { calibração }=0,011547005 \\
& \text { repe }=0,003162278 \\
& \Delta \mathrm{t}=0,001212436
\end{aligned}
$$

\section{Incerteza combinada}

$$
\mathrm{u}_{\mathrm{c}}\left(\mathrm{DBP}_{\text {sol_trabalho1 }}\right)=0,016311998 \mu \mathrm{g} \cdot \mathrm{mL}^{-1}
$$

4. Incerteza da preparação da solução de trabalho 2

Grandezas de entrada: incerteza da solução estoque, volume pipetado da solução de trabalho 1 para preparação da solução mista de trabalho e volume final da solução mista de trabalho.

Componentes de incertezas

$$
\begin{aligned}
& \mathrm{u}\left(\mathrm{C}_{\text {sol. estoque }}\right)= 0,016311998 \mu \mathrm{g} \cdot \mathrm{mL}^{-1} \\
& \mathrm{u}\left(\mathrm{V}_{\text {i_estoque }}\right)= 0,001001836 \mu \mathrm{g} \cdot \mathrm{mL}^{-1} \\
& \text { calibração }=0,000866025 \\
& \text { repe }=0,0005 \\
& \Delta \mathrm{t}=6,06218 \mathrm{E}-05 \\
& \mathrm{u}\left(\mathrm{V}_{\text {final }}\right)=0,008824256 \mu \mathrm{g} \cdot \mathrm{mL}^{-1} \\
& \text { calibração }=0,008660254 \\
& \text { repe }=0,001581139 \\
& \Delta \mathrm{t}=0,000606218
\end{aligned}
$$




\section{Incerteza combinada \\ $\mathrm{U}_{\mathrm{c}}\left(\mathrm{DBP}_{\text {sol_trabalho2 }}\right)=0,002096932 \mu \mathrm{g} \cdot \mathrm{mL}^{-1}$}

5. Incerteza da preparação das soluções de calibração para a curva analítica Grandezas de entrada: incerteza da solução de trabalho, volume pipetado da solução de trabalho e volume dos balões usados para diluição das soluções.

Incerteza volume pipetado para cada solução da curva

$$
\begin{aligned}
& \mathrm{u}(\mathrm{V} 1 \text { _sol.trabalho })=0,000867489 \mu \mathrm{g} \cdot \mathrm{mL}^{-1} \\
& \text { calibração }=0,000866025 \\
& \text { repe }=0,00005 \\
& \Delta \mathrm{t}=6,06218 \mathrm{E}-06 \\
& \mathrm{u}(\mathrm{V} 2 \text { _sol.trabalho })=0,001734978 \mu \mathrm{g} \cdot \mathrm{mL}^{-1} \\
& \text { calibração = 0,001732051 } \\
& \text { repe }=0,0001 \\
& \Delta \mathrm{t}=1,21244 \mathrm{E}-05 \\
& \mathrm{u}(\text { V3_sol.trabalho })=0,000234429 \mu \mathrm{g} \cdot \mathrm{mL}^{-1} \\
& \text { calibração }=0,00023094 \\
& \text { repe }=0,00004 \\
& \Delta \mathrm{t}=4,84974 \mathrm{E}-06 \\
& \mathrm{u}(\text { V4_sol.trabalho })=0,000644679 \mu \mathrm{g} \cdot \mathrm{mL}^{-1} \\
& \text { calibração }=0,000635085 \\
& \text { repe }=0,00011 \\
& \Delta \mathrm{t}=1,33368 \mathrm{E}-05 \\
& \mathrm{u}(\mathrm{V} 5 \text { _sol.trabalho })=0,001172144 \mu \mathrm{g} \cdot \mathrm{mL}^{-1} \\
& \text { calibração }=0,001154701 \\
& \text { repe }=0,0002 \\
& \Delta \mathrm{t}=2,42487 \mathrm{E}-05
\end{aligned}
$$

Incerteza balão volumétrico $1 \mathrm{~mL}$

$$
\begin{aligned}
\mathrm{u}\left(\mathrm{V}_{-} 1 \mathrm{~mL}\right)= & 0,005774776 \mu \mathrm{g} \cdot \mathrm{mL}^{-1} \\
& \text { calibração }=0,005773503 \\
& \text { repe }=0 \\
& \Delta \mathrm{t}=0,000121244
\end{aligned}
$$

Incerteza combinada para cada uma das soluções da curva

$\mathrm{u}_{\mathrm{c}}\left(\right.$ DBP_C1 $\left.1_{\text {sol_curva }}\right)=0,000459476 \mu \mathrm{g} \cdot \mathrm{mL}^{-1}$ (solução $0,025 \mu \mathrm{g} \cdot \mathrm{mL}^{-1}$ )

$\mathrm{u}_{\mathrm{c}}\left(\mathrm{DBP} \_\mathrm{C} 2_{\text {sol_curva }}\right)=0,000918953 \mu \mathrm{g} \cdot \mathrm{mL}^{-1}$ (solução $0,05 \mu \mathrm{g} \cdot \mathrm{mL}^{-1}$ )

$\mathrm{u}_{\mathrm{c}}\left(\right.$ DBP_C3 $\left.3_{\text {sol_curva }}\right)=0,001705526 \mu \mathrm{g} \cdot \mathrm{mL}^{-1}$ (solução $0,20 \mu \mathrm{g} \cdot \mathrm{mL}^{-1}$ )

$\mathrm{u}_{\mathrm{c}}\left(\mathrm{DBP} \_C 4_{\text {sol_curva }}\right)=0,004690198 \mu \mathrm{g} \cdot \mathrm{mL}^{-1}$ (solução $0,55 \mu \mathrm{g} \cdot \mathrm{mL}^{-1}$ )

$\mathrm{u}_{\mathrm{c}}\left(\mathrm{DBP} \_5_{\text {sol_curva }}\right)=0,008527632 \mu \mathrm{g} \cdot \mathrm{mL}^{-1}$ (solução $1,00 \mu \mathrm{g} \cdot \mathrm{mL}^{-1}$ )

Os cálculos até aqui apresentados podem ser aplicados às duas matrizes (água bruta e tratada), uma vez que as grandezas de entrada não 
envolvem as respostas das amostras. A seguir são descritas individualmente as incertezas calculadas para as curvas analíticas e a recuperação de cada matriz.

\section{$\Rightarrow \quad$ MATRIZ ÁGUA TRATADA}

6. Incerteza da curva analítica

Grandezas de entrada: área da amostras, área do branco, soluções da curva (C1 a C5), áreas referentes às soluções da curva.

\section{Incerteza combinada da curva analítica \\ $\mathrm{u}_{\mathrm{c}}\left(\mathrm{DBP}_{\text {curva_analítica }}\right)=0,0047 \mu \mathrm{g} \cdot \mathrm{mL}^{-1}$}

7. Incerteza da recuperação

Grandezas de entrada: concentração da solução padrão e resultado da concentração encontrada.

$$
\begin{aligned}
& \text { Incerteza combinada da recuperação } \\
& \mathrm{u}_{\mathrm{c}}\left(\mathrm{DBP}_{\text {recuperação }}\right)=0,0133022 \mu \mathrm{g} \cdot \mathrm{mL}^{-1} \\
& \mathrm{u}\left(\mathrm{C}_{\text {real }}\right)=0,006423301 \mu \mathrm{g} \cdot \mathrm{mL}^{-1} \\
& \mathrm{u}\left(\mathrm{C}_{\text {encontrada }}\right)=0,01233278 \mu \mathrm{g} \cdot \mathrm{mL}^{-1}
\end{aligned}
$$

\section{$\Rightarrow \quad$ MATRIZ ÁGUA BRUTA}

6. Incerteza da curva analítica

Grandezas de entrada: área da amostras, área do branco, soluções da curva (C1 a C5), áreas referentes às soluções da curva.

$$
\begin{aligned}
& \text { Incerteza combinada da curva analítica } \\
& \mathrm{u}_{\mathrm{c}}\left(\mathrm{DBP}_{\text {curva_analítica }}\right)=0,0030 \mu \mathrm{g} \cdot \mathrm{mL}^{-1}
\end{aligned}
$$

7. Incerteza da recuperação

Grandezas de entrada: concentração da solução padrão e resultado da concentração encontrada.

$$
\begin{aligned}
& \text { Incerteza combinada da recuperação } \\
& \begin{array}{r}
\mathrm{u}_{\mathrm{c}}(\mathrm{DBP} \text { recuperação })=0,0080976 \mu \mathrm{g} \cdot \mathrm{mL}^{-1} \\
\mathrm{u}\left(\mathrm{C}_{\text {real }}\right)=0,006423301 \mu \mathrm{g} \cdot \mathrm{mL}^{-1} \\
\mathrm{u}\left(\mathrm{C}_{\text {encontrada }}\right)=0,007867535 \mu \mathrm{g} \cdot \mathrm{mL}^{-1}
\end{array}
\end{aligned}
$$




\section{CÁLCULO DE INCERTEZAS PARA O NONILFENOL (NP)}

1. Incerteza da preparação da solução padrão

Grandezas de entrada: pureza do padrão e volume final da solução estoque.

Componentes de incertezas

$\mathrm{u}(\mathrm{P})=0,0433013 \mu \mathrm{g} \cdot \mathrm{mL}^{-1}$

$\mathrm{u}(\mathrm{V})=0,0151438 \mu \mathrm{g} \cdot \mathrm{mL}^{-1}$

Incerteza combinada

$\mathrm{u}_{\mathrm{c}}\left(\mathrm{NP}_{\text {sol.padrão }}\right)=0,00092 \mu \mathrm{g} \cdot \mathrm{mL}^{-1}$

2. Incerteza da preparação da solução de trabalho intermediária

Grandezas de entrada: incerteza da solução estoque, volume pipetado da solução estoque individual para preparação da solução mista de trabalho e volume final da solução mista de trabalho.

Componentes de incertezas

$$
\begin{gathered}
\mathrm{u}\left(\mathrm{C}_{\text {sol. estoque }}\right)=0,00091746 \mu \mathrm{g} \cdot \mathrm{mL}^{-1} \\
\mathrm{u}\left(\mathrm{V}_{\text {i_estoque }}\right) \\
0,001001836 \mu \mathrm{g} \cdot \mathrm{mL}^{-1} \\
\text { calibração }=0,000866025 \\
\text { repe }=0,0005 \\
\Delta \mathrm{t}=6,06218 \mathrm{E}-05 \\
\mathrm{u}\left(\mathrm{V}_{\text {tinal }}\right)=0,012033426 \mu \mathrm{g} \cdot \mathrm{mL}^{-1} \\
\text { calibração }=0,011547005 \\
\text { repe }=0,003162278 \\
\Delta \mathrm{t}=0,001212436
\end{gathered}
$$

\section{Incerteza combinada}

$\mathrm{u}_{\mathrm{c}}\left(\mathrm{NP}_{\text {sol_intermediária }}\right)=2,161955414 \mu \mathrm{g} \cdot \mathrm{mL}^{-1}$

3. Incerteza da preparação da solução de trabalho 1

Grandezas de entrada: incerteza da solução estoque, volume pipetado da solução de trabalho intermediária para preparação da solução mista de trabalho e volume final da solução mista de trabalho.

Componentes de incertezas

$$
\begin{aligned}
& \mathrm{u}\left(\mathrm{C}_{\text {sol. estoque }}\right)=2,161955414 \mu \mathrm{g} \cdot \mathrm{mL}^{-1} \\
& \mathrm{u}\left(\mathrm{V}_{\text {i_estoque }}\right)=0,000200367 \mu \mathrm{g} \cdot \mathrm{mL}^{-1} \\
& \text { calibração }=0,000173205 \\
& \text { repe }=0,0001 \\
& \Delta \mathrm{t}=1,21244 \mathrm{E}-05 \\
& \mathrm{u}\left(\mathrm{V}_{\text {final }}\right)=0,012033426 \mu \mathrm{g} \cdot \mathrm{mL}^{-1} \\
& \text { calibração }=0,011547005 \\
& \text { repe }=0,003162278 \\
& \Delta \mathrm{t}=0,001212436
\end{aligned}
$$




\section{Incerteza combinada \\ $\mathrm{u}_{\mathrm{c}}\left(\mathrm{NP}_{\text {sol_trabalho1 }}\right)=0,030574667 \mu \mathrm{g} \cdot \mathrm{mL}^{-1}$}

4. Incerteza da preparação da solução de trabalho 2

Grandezas de entrada: incerteza da solução estoque, volume pipetado da solução de trabalho 1 para preparação da solução mista de trabalho e volume final da solução mista de trabalho.

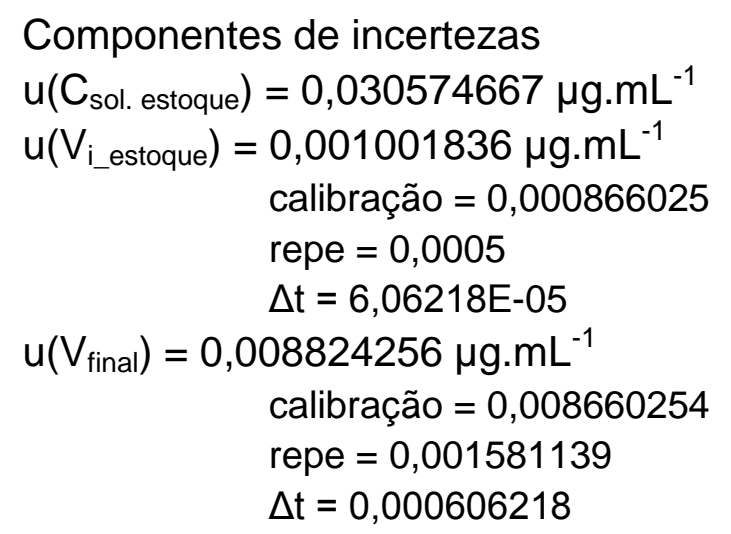

\section{Incerteza combinada}

$\mathrm{u}_{\mathrm{c}}\left(\mathrm{NP}_{\text {sol_trabalho2 }}\right)=0,003930419 \mu \mathrm{g} \cdot \mathrm{mL}^{-1}$

5. Incerteza da preparação das soluções de calibração para a curva analítica Grandezas de entrada: incerteza da solução de trabalho, volume pipetado da solução de trabalho e volume dos balões usados para diluição das soluções.

Incerteza volume pipetado para cada solução da curva

$$
\begin{aligned}
& \mathrm{u}\left(\mathrm{V} 1_{\text {_sol.trabalho }}\right)=0,000867489 \mu \mathrm{g} \cdot \mathrm{mL}^{-1} \\
& \text { calibração }=0,000866025 \\
& \text { repe }=0,00005 \\
& \Delta \mathrm{t}=6,06218 \mathrm{E}-06 \\
& \mathrm{u}(\text { V2_sol.trabalho })=0,001734978 \mu \mathrm{g} \cdot \mathrm{mL}^{-1} \\
& \text { calibração }=0,001732051 \\
& \text { repe }=0,0001 \\
& \Delta \mathrm{t}=1,21244 \mathrm{E}-05 \\
& \mathrm{u}(\mathrm{V} \text { __sol.trabalho })=0,000234429 \mu \mathrm{g} \cdot \mathrm{mL}^{-1} \\
& \text { calibração }=0,00023094 \\
& \text { repe }=0,00004 \\
& \Delta \mathrm{t}=4,84974 \mathrm{E}-06 \\
& \mathrm{u}(\mathrm{V} 4 \text { _sol.trabalho })=0,000644679 \mu \mathrm{g} \cdot \mathrm{mL}^{-1} \\
& \text { calibração }=0,000635085 \\
& \text { repe }=0,00011 \\
& \Delta \mathrm{t}=1,33368 \mathrm{E}-05 \\
& \mathrm{u}(\mathrm{V} 5 \text { _sol.trabalho })=0,001172144 \mu \mathrm{g} \cdot \mathrm{mL}^{-1} \\
& \text { calibração }=0,001154701 \\
& \text { repe }=0,0002
\end{aligned}
$$




$$
\begin{gathered}
\Delta t=2,42487 \mathrm{E}-05 \\
\text { Incerteza balão volumétrico } 1 \mathrm{~mL} \\
\mathrm{u}\left(\mathrm{V}_{-} 1 \mathrm{~mL}\right)=0,005774776 \mu \mathrm{g} \cdot \mathrm{mL}^{-1} \\
\text { calibração }=0,005773503 \\
\text { repe }=0 \\
\Delta t=0,000121244
\end{gathered}
$$

Incerteza combinada para cada uma das soluções da curva $\mathrm{U}_{\mathrm{c}}\left(\mathrm{NP} \_\mathrm{C} 1_{\text {sol_curva }}\right)=0,000852589 \mu \mathrm{g} \cdot \mathrm{mL}^{-1}$ (solução $0,050 \mu \mathrm{g} \cdot \mathrm{mL}^{-1}$ ) $\mathrm{U}_{\mathrm{c}}\left(\mathrm{NP} \_\mathrm{C} 2\right.$ sol_curva $)=0,001705178 \mu \mathrm{g} \cdot \mathrm{mL}^{-1}$ (solução $0,100 \mu \mathrm{g} \cdot \mathrm{mL}^{-1}$ ) $\mathrm{U}_{\mathrm{c}}\left(\mathrm{NP} \_\mathrm{C} 3\right.$ sol_curva $)=0,003164718 \mu \mathrm{g} \cdot \mathrm{mL}^{-1}$ (solução $0,400 \mu \mathrm{g} \cdot \mathrm{mL}^{-1}$ ) $\mathrm{u}_{\mathrm{c}}\left(\mathrm{NP} \_\mathrm{C} 4_{\text {sol_curva }}\right)=0,008702974 \mu \mathrm{g} \cdot \mathrm{mL}^{-1}$ (solução $1,100 \mu \mathrm{g} \cdot \mathrm{mL}^{-1}$ ) $\mathrm{u}_{\mathrm{c}}\left(\mathrm{NP} \_\mathrm{C} 5_{\text {sol_curva }}\right)=0,01582359 \mu \mathrm{g} \cdot \mathrm{mL}^{-1}$ (solução $2,000 \mu \mathrm{g} \cdot \mathrm{mL}^{-1}$ )

Os cálculos até aqui apresentados podem ser aplicados às duas matrizes (água bruta e tratada), uma vez que as grandezas de entrada não envolvem as respostas das amostras. A seguir são descritas individualmente as incertezas calculadas para as curvas analíticas e a recuperação de cada matriz.

\section{$\Rightarrow \quad$ MATRIZ ÁGUA TRATADA}

6. Incerteza da curva analítica

Grandezas de entrada: área da amostras, área do branco, soluções da curva ( $\mathrm{C} 1$ a C5), áreas referentes às soluções da curva.

$$
\begin{aligned}
& \text { Incerteza combinada da curva analítica } \\
& u_{c}\left(N_{\text {curva_analítica }}\right)=0,0037 \mu \mathrm{g} \cdot \mathrm{mL}^{-1}
\end{aligned}
$$

7. Incerteza da recuperação

Grandezas de entrada: concentração da solução padrão e resultado da concentração encontrada.

\section{Incerteza combinada da recuperação}

$$
\begin{aligned}
& \mathrm{u}_{\mathrm{c}}\left(\mathrm{NP} \mathrm{P}_{\text {recuperação }}\right)=0,0138107 \mu \mathrm{g} \cdot \mathrm{mL}^{-1} \\
& \mathrm{u}\left(\mathrm{C}_{\text {real }}\right)=0,006423301 \mu \mathrm{g} \cdot \mathrm{mL}^{-1} \\
& \mathrm{u}\left(\mathrm{C}_{\text {encontrada }}\right)=0,014063731 \mu \mathrm{g} \cdot \mathrm{mL}^{-1}
\end{aligned}
$$

\section{$\Rightarrow \quad$ MATRIZ ÁGUA BRUTA}

6. Incerteza da curva analítica

Grandezas de entrada: área da amostras, área do branco, soluções da curva (C1 a C5), áreas referentes às soluções da curva.

\section{Incerteza combinada da curva analítica}

$$
\mathrm{u}_{\mathrm{c}}\left(\mathrm{NP}_{\text {curva_analítica }}\right)=0,0054 \mu \mathrm{g} \cdot \mathrm{mL}^{-1}
$$


7. Incerteza da recuperação

Grandezas de entrada: concentração da solução padrão e resultado da concentração encontrada.

$$
\begin{aligned}
& \text { Incerteza combinada da recuperação } \\
& \begin{aligned}
\mathrm{u}_{\mathrm{c}}\left(\mathrm{NP}_{\text {recuperação }}\right)=0,0174090 \mu \mathrm{g} \cdot \mathrm{mL}^{-1} \\
\mathrm{u}\left(\mathrm{C}_{\text {real }}\right)=0,006423301 \mu \mathrm{g} \cdot \mathrm{mL}^{-1} \\
\mathrm{u}\left(\mathrm{C}_{\text {encontrada }}\right)=0,022535153 \mu \mathrm{g} \cdot \mathrm{mL}^{-1}
\end{aligned}
\end{aligned}
$$

\section{CÁLCULO DE INCERTEZAS PARA O PENTACLOROFENOL (PCP)}

1. Incerteza da preparação da solução padrão

Grandezas de entrada: massa do padrão, pureza do padrão e volume final da solução estoque.

Componentes de incertezas

$$
\begin{aligned}
& \mathrm{u}(\mathrm{m})=0,0353701 \mu \mathrm{g} \cdot \mathrm{mL}^{-1} \\
& \mathrm{u}(\mathrm{P})=0,0023094 \mu \mathrm{g} \cdot \mathrm{mL}^{-1} \\
& \mathrm{u}(\mathrm{V})=0,0120944 \mu \mathrm{g} \cdot \mathrm{mL}^{-1} \\
& \text { Incerteza combinada } \\
& \mathrm{u}_{\mathrm{c}}\left(\mathrm{PCP}_{\text {sol.padrão }}\right)=0,00375 \mu \mathrm{g} \cdot \mathrm{mL}^{-1}
\end{aligned}
$$

2. Incerteza da preparação da solução de trabalho 1

Grandezas de entrada: incerteza da solução estoque, volume pipetado da solução estoque individual para preparação da solução mista de trabalho e volume final da solução mista de trabalho.

Componentes de incertezas

$$
\begin{aligned}
& \mathrm{u}\left(\mathrm{C}_{\text {sol. estoque }}\right)=0,003745194 \mu \mathrm{g} \cdot \mathrm{mL}^{-1} \\
& \mathrm{u}\left(\mathrm{V}_{\text {i_estoque }}\right)=0,004007343 \mu \mathrm{g} \cdot \mathrm{mL}^{-1} \\
& \text { calibração }=0,003464102 \\
& \text { repe }=0,002 \\
& \Delta \mathrm{t}=0,000242487 \\
& \begin{array}{c}
\mathrm{u}\left(\mathrm{V}_{\text {final }}\right)=0,012033426 \mu \mathrm{g} \cdot \mathrm{mL}^{-1} \\
\text { calibração }=0,011547005 \\
\text { repe }=0,003162278 \\
\Delta \mathrm{t}=0,001212436
\end{array}
\end{aligned}
$$

Incerteza combinada

$$
\mathrm{u}_{\mathrm{c}}\left(\mathrm{PCP}_{\text {sol_intermediária }}\right)=0,046564027 \mu \mathrm{g} \cdot \mathrm{mL}^{-1}
$$

3. Incerteza da preparação da solução de trabalho 2

Grandezas de entrada: incerteza da solução estoque, volume pipetado da solução de trabalho 1 para preparação da solução mista de trabalho e volume final da solução mista de trabalho. 
Componentes de incertezas

$$
\begin{aligned}
& \mathrm{u}\left(\mathrm{C}_{\text {sol. estoque }}\right)=0,046564027 \mu \mathrm{g} \cdot \mathrm{mL}^{-1} \\
& \mathrm{u}\left(\mathrm{V}_{\text {i_estoque }}\right)=0,001001836 \mu \mathrm{g} \cdot \mathrm{mL}^{-1} \\
& \text { calibração }=0,000866025 \\
& \text { repe }=0,0005 \\
& \Delta \mathrm{t}=6,06218 \mathrm{E}-05 \\
& \mathrm{u}\left(\mathrm{V}_{\text {final }}\right)=0,008824256 \mu \mathrm{g} \cdot \mathrm{mL}^{-1} \\
& \text { calibração }=0,008660254 \\
& \text { repe }=0,001581139 \\
& \Delta \mathrm{t}=0,000606218
\end{aligned}
$$

\section{Incerteza combinada}

$\mathrm{u}_{\mathrm{c}}\left(\mathrm{PCP} \mathrm{P}_{\text {sol_trabalho2 }}\right)=0,007069088 \mu \mathrm{g} \cdot \mathrm{mL}^{-1}$

4. Incerteza da preparação das soluções de calibração para a curva analítica Grandezas de entrada: incerteza da solução de trabalho, volume pipetado da solução de trabalho e volume dos balões usados para diluição das soluções.

Incerteza volume pipetado para cada solução da curva

$$
\begin{aligned}
& \mathrm{u}(\mathrm{V} 1 \text { _sol.trabalho })=0,000867489 \mu \mathrm{g} \cdot \mathrm{mL}^{-1} \\
& \text { calibração }=0,000866025 \\
& \text { repe }=0,00005 \\
& \Delta \mathrm{t}=6,06218 \mathrm{E}-06 \\
& \mathrm{u}(\mathrm{V} 2 \text { _sol.trabalho })=0,001734978 \mu \mathrm{g} \cdot \mathrm{mL}^{-1} \\
& \text { calibração }=0,001732051 \\
& \text { repe }=0,0001 \\
& \Delta \mathrm{t}=1,21244 \mathrm{E}-05 \\
& \mathrm{u}(\text { V3_sol.trabalho })=0,000234429 \mu \mathrm{g} \cdot \mathrm{mL}^{-1} \\
& \text { calibração }=0,00023094 \\
& \text { repe }=0,00004 \\
& \Delta \mathrm{t}=4,84974 \mathrm{E}-06 \\
& \mathrm{u}(\mathrm{V} 4 \text { _sol.trabalho })=0,000644679 \mu \mathrm{g} \cdot \mathrm{mL}^{-1} \\
& \text { calibração }=0,000635085 \\
& \text { repe }=0,00011 \\
& \Delta \mathrm{t}=1,33368 \mathrm{E}-05 \\
& \mathrm{u}(\mathrm{V} 5 \text { _sol.trabalho })=0,001172144 \mu \mathrm{g} \cdot \mathrm{mL}^{-1} \\
& \text { calibração }=0,001154701 \\
& \text { repe }=0,0002 \\
& \Delta \mathrm{t}=2,42487 \mathrm{E}-05
\end{aligned}
$$

Incerteza balão volumétrico $1 \mathrm{~mL}$

$$
\begin{aligned}
\mathrm{u}\left(\mathrm{V} \_1 \mathrm{~mL}\right)= & 0,005774776 \mu \mathrm{g} \cdot \mathrm{mL}^{-1} \\
& \text { calibração }=0,005773503 \\
& \text { repe }=0 \\
& \Delta \mathrm{t}=0,000121244
\end{aligned}
$$


Incerteza combinada para cada uma das soluções da curva
$\mathrm{u}_{\mathrm{c}}\left(\mathrm{PCP} C \mathrm{C} 1_{\text {sol_curva }}\right)=0,001836066 \mu \mathrm{g} \cdot \mathrm{mL}^{-1}$ (solução $0,100 \mu \mathrm{g} \cdot \mathrm{mL}^{-1}$ )
$\mathrm{u}_{\mathrm{c}}\left(\mathrm{PCP} \_\mathrm{C} 2_{\text {sol_curva }}\right)=0,003672131 \mu \mathrm{g} \cdot \mathrm{mL}^{-1}$ (solução $0,200 \mu \mathrm{g} \cdot \mathrm{mL}^{-1}$ )
$\mathrm{u}_{\mathrm{c}}\left(\mathrm{PCP} \_\mathrm{C} 3_{\text {sol_curva }}\right)=0,006815329 \mu \mathrm{g} \cdot \mathrm{mL}^{-1}$ (solução $0,800 \mu \mathrm{g} \cdot \mathrm{mL}^{-1}$ )
$\mathrm{u}_{\mathrm{c}}\left(\mathrm{PCP} \_\mathrm{C} 4_{\text {sol_curva }}\right)=0,018742154 \mu \mathrm{g} \cdot \mathrm{mL}^{-1}$ (solução $2,200 \mu \mathrm{g} \cdot \mathrm{mL}^{-1}$ )
$\mathrm{u}_{\mathrm{c}}(\mathrm{PCP}$ _C5 sol_curva $)=0,034076644 \mu \mathrm{g} \cdot \mathrm{mL}^{-1}$ (solução $4,000 \mu \mathrm{g} \cdot \mathrm{mL}^{-1}$ )

Os cálculos até aqui apresentados podem ser aplicados às duas matrizes (água bruta e tratada), uma vez que as grandezas de entrada não envolvem as respostas das amostras. A seguir são descritas individualmente as incertezas calculadas para as curvas analíticas e a recuperação de cada matriz.

\section{$\Rightarrow \quad$ MATRIZ ÁGUA TRATADA}

5. Incerteza da curva analítica

Grandezas de entrada: área da amostras, área do branco, soluções da curva (C1 a C5), áreas referentes às soluções da curva.

\section{Incerteza combinada da curva analítica}

$\mathrm{u}_{\mathrm{c}}(\mathrm{PCP}$ curva_analítica $)=0,0122 \mu \mathrm{g} \cdot \mathrm{mL}^{-1}$

6. Incerteza da recuperação

Grandezas de entrada: concentração da solução padrão e resultado da concentração encontrada.

\section{Incerteza combinada da recuperação}

$\mathrm{u}_{\mathrm{c}}(\mathrm{PCP}$ recuperação $)=0,0319 \mu \mathrm{g} \cdot \mathrm{mL}^{-1}$

$$
\begin{aligned}
& \mathrm{u}\left(\mathrm{C}_{\text {real }}\right)=0,002337523 \mu \mathrm{g} \cdot \mathrm{mL}^{-1} \\
& \mathrm{u}\left(\mathrm{C}_{\text {encontrada }}\right)=0,03325561 \mu \mathrm{g} \cdot \mathrm{mL}^{-1}
\end{aligned}
$$

\section{$\Rightarrow \quad$ MATRIZ ÁGUA BRUTA}

5. Incerteza da curva analítica

Grandezas de entrada: área da amostras, área do branco, soluções da curva (C1 a C5), áreas referentes às soluções da curva.

$$
\begin{aligned}
& \text { Incerteza combinada da curva analítica } \\
& \mathrm{u}_{\mathrm{c}}\left(\mathrm{PCP} \mathrm{Curva}_{\text {analítica }}\right)=0,0145 \mu \mathrm{g} \cdot \mathrm{mL}^{-1}
\end{aligned}
$$

6. Incerteza da recuperação

Grandezas de entrada: concentração da solução padrão e resultado da concentração encontrada.

$$
\begin{aligned}
& \text { Incerteza combinada da recuperação } \\
& u_{c}\left(P C P_{\text {recuperação }}=0,0177 \mu \mathrm{g} \cdot \mathrm{mL}^{-1}\right. \\
& \qquad \mathrm{u}\left(\mathrm{C}_{\text {real }}\right)=0,002337523 \mu \mathrm{g} \cdot \mathrm{mL}^{-1}
\end{aligned}
$$




$$
\mathrm{u}\left(\mathrm{C}_{\text {encontrada }}\right)=0,019075052 \mu \mathrm{g} \cdot \mathrm{mL}^{-1}
$$

\section{CÁLCULO DE INCERTEZAS PARA O BISFENOL A (BPA)}

1. Incerteza da preparação da solução padrão

Grandezas de entrada: massa do padrão, pureza do padrão e volume final da solução estoque.

Componentes de incertezas

$$
\begin{aligned}
& \mathrm{u}(\mathrm{m})=0,0353701 \mu \mathrm{g} \cdot \mathrm{mL}^{-1} \\
& \mathrm{u}(\mathrm{P})=0,0051962 \mu \mathrm{g} \cdot \mathrm{mL}^{-1} \\
& \mathrm{u}(\mathrm{V})=0,0120944 \mu \mathrm{g} \cdot \mathrm{mL}^{-1} \\
& \text { Incerteza combinada }
\end{aligned}
$$

$$
\mathrm{u}_{\mathrm{c}}\left(\mathrm{BPA}_{\text {sol.padrão }}\right) 0,00377 \mu \mathrm{g} \cdot \mathrm{mL}^{-1}
$$

2. Incerteza da preparação da solução de trabalho 1

Grandezas de entrada: incerteza da solução estoque, volume pipetado da solução estoque individual para preparação da solução mista de trabalho e volume final da solução mista de trabalho.

Componentes de incertezas

$$
\begin{aligned}
& \mathrm{u}\left(\mathrm{C}_{\text {sol. estoque }}\right)=0,003774009 \mu \mathrm{g} \cdot \mathrm{mL}^{-1} \\
& \mathrm{u}\left(\mathrm{V}_{\text {i_estoque }}\right)=0,004007343 \mu \mathrm{g} \cdot \mathrm{mL}^{-1} \\
& \text { calibração }=0,003464102 \\
& \text { repe }=0,002 \\
& \Delta \mathrm{t}=0,000242487 \\
& \begin{array}{c}
\mathrm{u}\left(\mathrm{V}_{\text {final }}\right)=0,012033426 \mu \mathrm{g} \cdot \mathrm{mL}^{-1} \\
\text { calibração }=0,011547005 \\
\text { repe }=0,003162278 \\
\Delta \mathrm{t}=0,001212436
\end{array}
\end{aligned}
$$

Incerteza combinada

$$
\mathrm{u}_{\mathrm{c}}\left(\mathrm{BPA}_{\mathrm{sol} \_ \text {intermediária }}\right)=0,046330426 \mu \mathrm{g} \cdot \mathrm{mL}^{-1}
$$

3. Incerteza da preparação da solução de trabalho 2

Grandezas de entrada: incerteza da solução estoque, volume pipetado da solução de trabalho 1 para preparação da solução mista de trabalho e volume final da solução mista de trabalho.

$$
\begin{aligned}
& \text { Componentes de incertezas } \\
& \mathrm{u}\left(\mathrm{C}_{\text {sol. estoque }}\right) \begin{array}{l}
0,046330426 \mu \mathrm{g} \cdot \mathrm{mL}^{-1} \\
\mathrm{u}\left(\mathrm{V}_{\text {i_estoque }}\right)= \\
\text { calibração }=0,0000866025
\end{array}
\end{aligned}
$$




$$
\begin{gathered}
\text { repe }=0,0005 \\
\Delta t=6,06218 \mathrm{E}-05 \\
\mathrm{u}\left(\mathrm{V}_{\text {final }}\right)=0,008824256 \mu \mathrm{g} \cdot \mathrm{mL}^{-1} \\
\text { calibração }=0,008660254 \\
\text { repe }=0,001581139 \\
\Delta \mathrm{t}=0,000606218 \\
\text { Incerteza combinada } \\
\mathrm{u}_{\mathrm{c}}\left(\mathrm{BPA}_{\text {sol_trabalho2 }}\right)=0,007033611 \mu \mathrm{g} \cdot \mathrm{mL}^{-1}
\end{gathered}
$$

4. Incerteza da preparação das soluções de calibração para a curva analítica Grandezas de entrada: incerteza da solução de trabalho, volume pipetado da solução de trabalho e volume dos balões usados para diluição das soluções.

$$
\begin{aligned}
& \text { Incerteza volume pipetado para cada solução da curva } \\
& \mathrm{u}(\mathrm{V} 1 \text { _sol.trabalho })=0,000867489 \mu \mathrm{g} \cdot \mathrm{mL}^{-1} \\
& \text { calibração }=0,000866025 \\
& \text { repe }=0,00005 \\
& \Delta \mathrm{t}=6,06218 \mathrm{E}-06 \\
& \mathrm{u}(\mathrm{V} 2 \text { _sol.trabalho })=0,001734978 \mu \mathrm{g} \cdot \mathrm{mL}^{-1} \\
& \text { calibração }=0,001732051 \\
& \text { repe }=0,0001 \\
& \Delta \mathrm{t}=1,21244 \mathrm{E}-05 \\
& \mathrm{u}(\text { V3_sol.trabalho })=0,000234429 \mu \mathrm{g} \cdot \mathrm{mL}^{-1} \\
& \text { calibração }=0,00023094 \\
& \text { repe }=0,00004 \\
& \Delta \mathrm{t}=4,84974 \mathrm{E}-06 \\
& \mathrm{u}(\mathrm{V} 4 \text { _sol.trabalho })=0,00041025 \mu \mathrm{g} \cdot \mathrm{mL}^{-1} \\
& \text { calibração }=0,000404145 \\
& \text { repe }=0,00007 \\
& \Delta \mathrm{t}=8,48705 \mathrm{E}-06 \\
& \mathrm{u}(\mathrm{V} 5 \text { _sol.trabalho })=0,000879108 \mu \mathrm{g} \cdot \mathrm{mL}^{-1} \\
& \text { calibração }=0,000866025 \\
& \text { repe }=0,00015 \\
& \Delta \mathrm{t}=1,81865 \mathrm{E}-05 \\
& \mathrm{u}\left(\mathrm{V}_{-} 1 \mathrm{~mL}\right)=0,005774776 \mu \mathrm{g} \cdot \mathrm{mL}^{-1} \\
& \text { calibração }=0,005773503 \\
& \text { repe }=0 \\
& \Delta \mathrm{t}=0,000121244
\end{aligned}
$$

Incerteza combinada para cada uma das soluções da curva $\mathrm{u}_{\mathrm{c}}\left(\mathrm{BPA}\right.$ _C1 $\left.1_{\text {sol_curva }}\right)=0,001826849 \mu \mathrm{g} \cdot \mathrm{mL}^{-1}$ (solução $0,100 \mu \mathrm{g} \cdot \mathrm{mL}^{-1}$ ) $\mathrm{u}_{\mathrm{c}}\left(\mathrm{BPA} \_\mathrm{C} 2_{\text {sol_curva }}\right)=0,003653697 \mu \mathrm{g} \cdot \mathrm{mL}^{-1}$ (solução $0,200 \mu \mathrm{g} \cdot \mathrm{mL}^{-1}$ ) $\mathrm{u}_{\mathrm{c}}\left(\mathrm{BPA}\right.$ _C3 $\left.3_{\text {sol_curva }}\right)=0,006781117 \mu \mathrm{g} \cdot \mathrm{mL}^{-1}$ (solução $0,800 \mu \mathrm{g} \cdot \mathrm{mL}^{-1}$ ) $\mathrm{u}_{\mathrm{c}}\left(\mathrm{BPA} \_\mathrm{C} 4_{\text {sol_curva }}\right)=0,011866955 \mu \mathrm{g} \cdot \mathrm{mL}^{-1}$ (solução $1,400 \mu \mathrm{g} \cdot \mathrm{mL}^{-1}$ ) 


$$
\mathrm{u}_{\mathrm{c}}\left(\mathrm{BPA} \_\mathrm{C} 5_{\text {sol_curva }}\right)=0,025429188 \mu \mathrm{g} \cdot \mathrm{mL}^{-1} \text { (solução } 3,000 \mu \mathrm{g} \cdot \mathrm{mL}^{-1} \text { ) }
$$

Os cálculos até aqui apresentados podem ser aplicados às duas matrizes (água bruta e tratada), uma vez que as grandezas de entrada não envolvem as respostas das amostras. A seguir são descritas individualmente as incertezas calculadas para as curvas analíticas e a recuperação de cada matriz.

\section{$\Rightarrow \quad$ MATRIZ ÁGUA TRATADA}

5. Incerteza da curva analítica

Grandezas de entrada: área da amostras, área do branco, soluções da curva (C1 a C5), áreas referentes às soluções da curva.

\section{Incerteza combinada da curva analítica}

$\mathrm{u}_{\mathrm{c}}\left(\mathrm{BPA}_{\text {curva_analítica }}\right)=0,0152 \mu \mathrm{g} \cdot \mathrm{mL}^{-1}$

6. Incerteza da recuperação

Grandezas de entrada: concentração da solução padrão e resultado da concentração encontrada.

$$
\begin{aligned}
& \text { Incerteza combinada da recuperação } \\
& \mathrm{u}_{\mathrm{c}}\left(\mathrm{BPA}_{\text {recuperação }}\right)=0,0065 \mu \mathrm{g} \cdot \mathrm{mL}^{-1} \\
& \mathrm{u}\left(\mathrm{C}_{\text {real }}\right)=0,002337559 \mu \mathrm{g} \cdot \mathrm{mL}^{-1} \\
& \mathrm{u}\left(\mathrm{C}_{\text {encontrada }}\right)=0,007634777 \mu \mathrm{g} \cdot \mathrm{mL}^{-1}
\end{aligned}
$$

\section{$\Rightarrow \quad$ MATRIZ ÁGUA BRUTA}

5. Incerteza da curva analítica

Grandezas de entrada: área da amostras, área do branco, soluções da curva (C1 a C5), áreas referentes às soluções da curva.

$$
\begin{aligned}
& \text { Incerteza combinada da curva analítica } \\
& \mathrm{u}_{\mathrm{c}}\left(\mathrm{BPA}_{\text {curva_analítica }}\right)=0,0449 \mu \mathrm{g} \cdot \mathrm{mL}^{-1}
\end{aligned}
$$

6. Incerteza da recuperação

Grandezas de entrada: concentração da solução padrão e resultado da concentração encontrada.

\section{Incerteza combinada da recuperação}

$$
\begin{aligned}
& \mathrm{u}_{\mathrm{c}}\left(\mathrm{BPA}_{\text {recuperação }}\right)=0,0339 \mu \mathrm{g} \cdot \mathrm{mL}^{-1} \\
& \mathrm{u}\left(\mathrm{C}_{\text {real }}\right)=0,002337559 \mu \mathrm{g} \cdot \mathrm{mL}^{-1} \\
& \mathrm{u}\left(\mathrm{C}_{\text {encontrada }}\right)=0,032672374 \mu \mathrm{g} \cdot \mathrm{mL}^{-1}
\end{aligned}
$$




\section{REFERÊNCIAS BIBLIOGRÁFICAS}

AGEVAP - Agência da bacia do rio Paraíba do Sul. Relatório de atividade 2009. Resende, RJ: AGEVAP, 2009.

AHEL, M.; GIGER, W. Aqueous solubility of alkylphenols and alkylphenols polyethoxylates. Chemosphere, v. 26, n. 8, p. 1461-1470, 1993a.

AHEL, M.; GIGER, W. Partitioning of alkylphenols and alkylphenol polyethoxylates between water and organic solvents. Chemosphere, v. 26, n. 8, p. 1471-1478, 1993b.

AHEL, M.; GIGER, W.; SCHAFFNE, C. Behaviour of alkylphenols polyethoxylate surfactants in the aquatic environment - II. Occurrence and transformation in rivers. Water Res., v. 28, n. 5, p. 1143-1152, 1994a.

AHEL, M.; SCULlY, F.E.; HOIGNÉ, J.; GIGER, W. Photochemical degradation of nonylphenol and nonylphenol polyethoxylate in naturals water. Chemosphere, $v$. 28, n. 7, p. 1361-1368, 1994b.

ALLEN, E.; DOISY, E. A. The induction of a sexually mature condition in immature females by injection of the ovarian follicular hormone. Am. J. Physiol. n. 69, p. 577-588, 1924.

ALVES, C.; FLORES, L.C.; CERQUEIRA, T.S.; TORALLES, M.B.P. Exposição ambiental a interferentes endócrinos com atividade estrogênica e sua associação com distúrbios puberais em crianças. Cad. Saúde Pública, v.23, n.5, 2007.

AZEVEDO, D.A.; LACORTE, S.; VIANA, P.; BARCELÓ, D. Occurrence of nonylphenol and bisphenol-A in surface water from Portugal. J. Braz. Chem. Soc., v.12, n. 4, 2001.

BALlesteros-GÓMEZ, A.; RUBIO, S.; PÉREZ-BENDITO, D. Analytical methods for the determination of bisphenol $A$ in food. Journal of Chromatography A, v. 1216, 2009.

BARREK, S.; CREN-ÓLIVE, C.; WIEST, L.; BAUDOT, R.; ARNAUDGUILHEM, C.; GRENIER-LOUSTALOT, M. Mutli-residue analysis and ultra-trace quantification of 36 priotity substances from the European Water Framework Directive by GC-MS and LCFLC-MS/MS in surface water. Talanta, v. 79, p. 712-722, 2009.

BILA, D. M.; DEZOTTI, M. Desreguladores endócrinos no meio ambiente: efeitos e consequências. Química Nova, v. 30, n.3, p. 651-666, 2007.

BINETTI, R.; COSTAMAGMA, F.M.; MARCELLO, I. Exponential growth of new chemicals and evolution of information relevant to risk control. Ann Ist Super Sanitá, v. 44, n. 1, 2008.

BIRKETT, J. W., LESTER, J. N. Endocrine Disrupters in Wastewater and Sludge Treatment Process. Lewis Publishers (CRC Press), 2003.

BRAGA, B.P.F.; FLECHA, R.; PENA, D.S.; KELMAN, J. Federal pact and water management. Estudos avançados, v. 22, n. 63, 2008. 
BRASIL. Agência Nacional de Vigilância Sanitária do Ministério da Saúde (ANVISA). Consulta pública n 107, D.O.U. de 28/11/2003, Brasília, 2003.

BRASIL. Agência Nacional de Vigilância Sanitária do Ministério da Saúde (ANVISA). Resolução ${ }^{\circ}{ }^{164}$. D.O.U. de 21/08/2006, Brasília, 2006b.

BRASIL. Agência Nacional de Vigilância Sanitária do Ministério da Saúde (ANVISA). Resolução n` 899. D.O.U. de 29/05/2003, Brasília, 2003.

BRASIL. Agência Nacional de Vigilância Sanitária do Ministério da Saúde (ANVISA). Gerência Geral de Toxicologia. Nota técnica sobre a reavaliação toxicológica do ingrediente ativo pentaclorofenol e seus sais.Brasília, 2006a.

BRASIL. Ministério do desenvolvimento urbano e meio ambiente. Conselho nacional do meio ambiente (CONAMA). Resolução n. 357, D.O.U. de 17/03/05, Brasília, 2005a.

BRASIL. Ministério da Saúde. Secretaria de Vigilância em Saúde. Portaria $n^{\circ} 518$ de 2004, Brasília, 2005b.

BRASIL. Ministério do desenvolvimento urbano e meio ambiente. Conselho nacional do meio ambiente (CONAMA). Resolução n. 397, D.O.U. de 03/04/08, Brasília, 2008.

BRITO, C.F.; MARTINS, E.A.J.; SOUZA, R.R.; OTOMO, J.I.; FURUSAWA, H.A.; FERNANDES, F.; COTRIM, M.E.B.; PIRES, M.A.P. Estudo de compostos orgânicos persistentes em águas destinadas ao abastecimento público na região de Santo André, SP. Desenvolvimento e validação de metodologia analítica. In: A. S. Messias; M. R. N. Costa. (Org.). Gestão Integrada de Ambientes Costeiros e Impactos Ambientais. Série Encontro das Águas, n.5. Recife: UNICAP. Recife/PE, 2009.

BRITO, C.F. Desenvolvimento e validação de metodologia analítica para determinação de hidrocarbonetos policíclicos aromáticos (HPAs) em sedimentos. Avaliação da represa do Parque do Parque Pedroso, Santo André, SP. Dissertação de mestrado, Instituto de Pesquisas Energéticas e Nucleares - IPEN/USP, São Paulo, 2009.

BROSSA, L.; MARCÉ, R.M.; BORRULL, F.; POCURULL, E. Determination of endocrinedisrupting compounds in water sample by on-line solid-phase extraction-programmedtemperature vaporization-gas chromatography-mass spectrometry. Journal of Chromatography A, v. 998, n. 41-50, 2003.

BROSSA, L.; MARCÉ, R.M.; BORRULL, F.; POCURULL, E. Determination of endocrine disruptors in environmental water samples by stir bar sorptive extraction- liquid desorption - large volume injection gas chromatography. Chromatographia, v. 61, p. 61-65, 2005.

CALAFAT, A.M.; KUKLENYIK, Z.; REIDY, J.A.; CAUDILL, S.P.; EKONG, J.; NEEDHAM, L.L. Urinary concentrations of bisphenol $A$ and 4-nonylphenol in a human reference population. Envir. Health Perspectives, v. 113, n. 4, 2005.

CANADA - Canadian Environmental Quality Guidelines. Canadian Water Quality Guidelines for the protection of aquatic life. Nonylphenol and its ethoxylates. 2002.

CANADA - Health of Minister. Federal Provincial Territorial Committee on Drinking Water. Guidelines for Canadian Drinking Water Quality. 6ed. Canada Communication Group: Ottawa, 1996.

CAS - Chemical Abstracts Service. American Chemical Society. Disponível em: < http://www.cas.org/index.html>. Acesso em 23 fev. 2011. 
CASAJUANA, N.; LACORTE, S. Presence and release of phthalic esters and other endocrine disrupting compounds in drinking water. Chromatographia, v. 57, p. 649-655, 2003.

CAVALCANTE, R.M. FILHO, N.S.M., VIANA, R.B., OLIVEIRA, I.R.N., NASCIMENTO, R.F., SILVEIRA, E.R., FREIRE, G.S.S. Utilização da extração em fase sólida (SPE) na determinação de hidrocarbonetos aromáticos em matrizes aquosas ambientais. Química nova, v. 30, n. 3, p, 560-564. 2007.

CCME - Canada Council of Ministers of the Environment. Canadian Environmental Quality Guidelines. Disponível em: http://st-ts.ccme.ca/. Acesso em 24 fev. 2011.

CEC. Commission of the European communities. Community strategy for endocrine disrupters: a range of substances suspected of interfering with the hormone systems of humans and wildlife. Commission staff working document, Brussels, SEC (2007) 1635, 2007.

CEC. Commission of the European communities. Community strategy for endocrine disrupters: a range of substances suspected of interfering with the hormone systems of humans and wildlife. Communication from the commission to the council and the European parliament, Brussels, COM (1999) 706 final, 1999.

CETESB - Companhia de Tecnologia de Saneamento Ambiental. Guia de coleta e preservação de amostras de água. São Paulo: CETESB, 1987.

CETESB - Companhia Ambiental do Estado de São Paulo. Relatório de qualidade das águas interiores no estado de São Paulo 2009. São Paulo: CETESB, 2010. Disponível em: $\quad$ http://www.cetesb.sp.gov.br/agua/aguas-superficiais/35-publicacoes-/-relatorios. Acesso em 22 mar. 2011.

CEIVAP - AGEVAP. Relatório de situação: bacia hidrográfica do rio Paraíba do Sul 2008-2009. Resende, RJ: CEVAP - AGEVAP, 2009

CHUI, Q.S.H.; BARROS, C.B.; SILVA, T.D. Parâmetros $r$ e $R$ obtidos de programa interlaboratorial - como usá-los. Química Nova, v. 32, n. 8, 2009.

CIAGRO - Centro Integrado de Informações agrometereológicas. Ciiagro online. Disponível em: http://www.ciiagro.sp.gov.br/ciiagroonline/. Acesso em 12 abr. 2011.

COLBORN, T.; DUMANOSKI, D.; MYERS, J.P. O futuro roubado. Porto Alegre: L\&PM. 2002.

COLBORN, T.; vom SAAL, F.S.; SOTO, A.M. Developmental effects on endocrinedisrupting chemicals in wildlife and humans. Environmental health perspectives, v. 101, n. 5, 1993.

COLLINS, C.H.; BRAGA, G.L.; BONATO, P.S. Fundamentos de cromatografia. Campinas: Editora Unicamp, 2006.

COOK, J.W.; DODDS, E.C.; HEWETT, C.L. A synthetic oestrus-exciting compound. Nature, 131, 56, 1933.

DAMSTRA, T.; BARLOW, S.; BERGMAN, A.; KAVLOCK, R.; KRAAK, G.V.D. Global Assessment of the state-of-the-science of endocrine disruptors. IPCS - International Programme on Chemical Safety. Report WHO/PCS/ECD, Geneva, 2002. 
DEKANT, W.; VÖLKEL, W. Human exposure to bisphenol $A$ by biomonitoring: methods, results and assessment to environmental exposures. Toxicology and applied pharmacology, v. 228, p. 114-134, 2008.

DIAMANTI-KANDARAKIS, E.; BOURGUIGNON, J.P.; GIUDICE, C.L.; HAUSER, R.; PRINS, G. S.; SOTO, A. M., ZOELLER, R.T.; GORE, A.C. Endocrine Disrupting Chemicals: An Endocrine Society Scientific Statement. Endocrine Review, v.30(4), p.293-342. 2009.

DIANA, A.; DIMITRA, V. Alkylphenols and phthalates in botlled waters. Journal of Hazardous Materials, v. 185, p. 281-286, 2011.

DIAS, T.F.; BARROS, H.O.M. A gestão dos recursos hídricos no Brasil: avanços legais e a experiência pelo uso da água. In: A. S. Messias; M. R. N. Costa. (Org.). Água Tratamentos e políticas públicas. Série Encontro das águas, n.04. Recife: UNICAP. Recife/PE, 2007.

DINIZ, L.T. Efetivação das metas de qualidade de águas superficiais no Brasil. Dissertação de mestrado, PROCAM/USP, São Paulo, 2006.

DODDS, E.C.; LAWSON, W. Molecular structure in relation to oestrogenic activity. Compounds without phenanthrene nucleus. Proc. Royal Soc. London 118:222-32.1938.

DUARTE, P.A.F. Novos poluentes. Principais impactes de compostos desreguladores endócrinos na saúde pública. Dissertação de mestrado, Universidade Nova de Lisboa, Lisboa, 2008.

EC - European Communities. 4-nonylphenol (branched) and nonylphenol. European Union Riks Report. Luxemboug, 2002.

EC - European Communities. 4,4'-isopropylidenediphenol (bisphenol-A). European Union Riks Report. Luxemboug, 2003.

EC - European Communities. European Parliament and of the Council. Directive 98/83/EC. Official Journal European Communities, 1998.

EC - European Communities. European Parliament and of the Council. Directive 2000/60/EC. Official Journal European Communities, 2000.

EC - European Communities. European Parliament and of the Council. Directive 2008/105/CE. Official Journal European Communities, 2008.

EISLER, R. Pentachlorophenol. In: EISLER, R. Handbook of Chemical Risk Assessment - Health Hazards to Humans, Plants, and Animals. CRC Press, 2000.

EL SHAHAWI, M.S.; HAMZA, A.; BASHAMMAKH, A.S; AL SAGGAF, W.T. An overview on the accumulation, distribution, transformations, toxicity and analytical methods for the monitoring of persistent organic pollutants. Talanta, v. 80, p. 587-1597, 2010.

FCR. Plano da Bacia Hidrográfica do Paraíba do Sul - UGRHI 02 - 2009-2012. São Paulo: Fundação Christiano Rosa, 2009.

FERNANDES NETO, M. L.; FERREIRA, A.P. Perspectiva da sustentabilidade ambiental diante da contaminação química da água: desafios normativos. INTERFACEHS Revista de Gestão Integrada em Saúde do Trabalho e Meio Ambiente, v.2, n.4, 2007.

FROEHNER, S.; MARTINS, R.F. Avaliação do destino de benzo(a)pireno através de simulação computacional. Química nova, v. 31, n. 5, 2008. 
FROMME, H.; KÜCHLER, T.; OTTO, T.; PILZ, K.; MÜLLER, J.; WENDEL, A. Occurrence of phthalates and bisphenol $A$ and $F$ in the environment. Water research, v. 36, p. 14291438, 2002.

FURUSAWA, H. A. Validação de Ensaios Químicos. São Paulo, IPEN-CNEN/SP, 2007 (adaptação eletrônica baseada no documento DOQ-CGCRE-008 de 01/03/2003 do INMETRO).

GERHARD, I.; FRICK, A.; MONGA, B.; RUNNEBAUM, B. Pentachlorophenol exposure in women with gynecological and endocrine dysfunction. Environmental Research, Section A, v. 80, p. 383-388, 1999.

GEROLIN, E.R.R. Ocorrência e remoção de disruptores endócrinos em águas utilizadas para abastecimento público de Campinas e Sumaré - São Paulo. Universidade Estadual de Campinas, UNICAMP, Campinas, 2008.

GHISELLI, G. Avaliação da qualidade das águas destinadas ao abastecimento público na região de Campinas: ocorrência e determinação dos interferentes endócrinos (IE) e produtos farmacêuticos e de higiene pessoal (PFHP). Tese de doutorado, UNICAMP, Campinas, 2006.

GHISELLI, G; JARDIM, W. F. Interferentes endócrinos no ambiente. Química nova, v. 30, n. 3, 2007.

GIBBS, P.E.; PASCOE, P.E.; BRYAN, G.W. Tributyltin-induced imposex in stenoglossan gastropods: pathological effects on the female reproductive system. Comp. Biochem. Physiol., v. 100c, n.1/2, 1991.

GIBSON, R.; BECERRIL-BRAVO, E.; SILVA-CASTRO, V.; JIMÉNEZ, B. Determination of acidic pharmaceuticals and potencial endocrine disrupting compounds in wastewater and spring water by selective elution and analysis by gas chromatography-mass spectrometry. Journal of Chromatography A, v. 1169, p. 31-39, 2007.

GÓMEZ-HENZ, A.; AGUILAR-CABALLOS, M.P. Social end economic interest in the control of phthalic acid esters. Trends in Analyical Chemistry, v. 22, n. 11, 2003.

GONZÁLEZ, A.G.; HERRADOR, M.A. A practical guide to analytical method validation, including measurement uncertainty and accuracy profiles. Trends in Anal. Chem., v. 26., n. 3, 2007.

GOLOUBKOVA, T.; SPRITZER, P.M. Xenoestrogênios: o exemplo do bisfenol-A. Arq. Bras. Endrocrinologia Metab., v.44, p.323-329, 2000.

GOODHEAD, R.M. TYLER, C.R. Endocrine-disrupting chemicals and their environmental impacts. In: WALKER, C.H. (Ed.) Organic Pollutants: An Ecotoxicological Perspective. 2ed. CRC Press, 2009.

GRUBEN, A.; LOPES, P.D.; JOHNSON, R.M.F. A bacia do rio Paraíba do Sul, São Paulo, Rio de Janeiro e Minas Gerais - 2001. Brasília: Projeto Marca D'água, 2002.

GUIA CITAC/EURACHEM. Guia para qualidade em química analítica. Uma assistência à acreditação. Versão Brasileira. 2002.

GUIA EURACHEM. Determinando a incerteza na medição analítica. 2ed. Versão Brasileira. 2002.

GUYTON, A.C. Tratado de fisiologia médica. Rio de Janeiro: Guanabara Koogan, 9ed. 1997. 
HAN, X.D.; TU, Z.G.; GONG, Y.; SHEN, S.N.; WANG, X.Y.; KANG, L.N.; HOU, Y.Y.; CHEN, J.X. The toxic effects of nonylphenol on the reproductive system of male rats. Reproductive Toxicology, v. 19, p. 215-221, 2004.

HERNANDO, M.D.; MEZCUA, M.; GÓMEZ, M.J.; MALATO, O.; AGÜERA, A.; FERNÁNDEZ-ALBA, A.R. Comparative study of analytical mathods involving gas chromatography-mass spectrometry after derivatization and gas chromathographytandem mass spectrometry for the determination of selected endocrine disrupting compounds in wastewaters. Journal of Chromatography, v. 1047, p. 129-135, 2004.

HORWITZ, W.; ALBERT, R. The Horwitz ratio (HorRat): a useful index of method performance with respect to precision. Journal of AOAC International, v. 89, n. 4, 2006.

IARC - International Agency for Research on Cancer. Occupational Exposures in Insecticide Application, and Some Pesticides. Monography Pentachlorophenol. Lyon, v. 53. 1991.

IARC - International Agengy for Research on Câncer. Complete list of agents evaluated and their classification. Disponível em: <http://www.iarc.fr>. Acesso em: 25 fev. 2008.

IBGE - Instituto Brasileiro de Geografia e Estatística. IBGE Cidades. Disponível em< http://www.ibge.gov.br/cidadesat/topwindow.htm?1>. Acesso em 16 mar. 2011.

ICH - INTERNATIONAL CONFERENCE ON HARMONISATION OF TECHNICAL REQUIREMENTS FOR REGISTRATION OF PHARMACEUTICALS FOR HUMAN USE. Validation of analytical procedures: Text and methodology Q2(R1). Oct. 1994.

INMETRO - Instituto Nacional De Metrologia, Normalização e Qualidade Industrial. Orientação sobre validação de métodos de ensaios químicos. Rio de Janeiro. DOQCGCRE-008. Revisão 01. Mar. 2003.

INMETRO - Instituto Nacional de Metrologia, Normalização e Qualidade Industrial. Orientação sobre validação de métodos de ensaios químicos. Rio de Janeiro. DOQCGCRE-008. Revisão 02. Jun. 2007.

INMETRO - Instituto Nacional de Metrologia, Normalização e Qualidade Industrial. Orientação sobre validação de métodos de ensaios químicos. Rio de Janeiro. DOQCGCRE-008. Revisão 03. Fev. 2010.

INMETRO - Instituto Nacional de Metrologia, Normalização e Qualidade Industrial. NITDICLA-021. Expressão da incerteza de medição. Rev. 04 de fev. $2010 b$.

IPCS - International Programme on Chemical Safety. Environmental Health Criteria 71. Pentachlorophenol. $1987 . \quad$ Disponível em: <http://www.inchem.org/documents/ehc/ehc/ehc71.htm>. Acesso em 16 fev. 2011.

ISHIHARA, A.; SAWATSUBASHI, S.; YAMAUCHI, K. Endocrine disrupting chemicals: interference of thyroid hormone binding to transthyretins and to thyroid hormone receptors. Molecular and Cellular Endocrinology, v. 199, p. 105-117, 2003.

ISO-International Organization for Standardization Accuracy (trueness and precision) of Measurement Methods and Results - Part 2: basic method for the Determination of Repeatability and Reprodutibility of a Standard Measurement Method. ISO 57252. 1998 .

JIN, X.; JIANG, G.; HUANG, G.; LIU, J.; ZHOU, Q. Determination of 4-tert-octylphenol, 4nonylphenol and bisphenol $A$ in surface water from the Haihe River in Tianjin by gas 
chromatography-mass spectrometry with selected ion monitoring. Chemosphere, v. 56, p.1113-1119, 2004.

JOHNSTONE, R.A.W.; HERBERT, C.G. Mass spectrometry basics. CRC Press, 2002.

JUNQUEIRA, L. C. U.; CARNEIRO, J. Histologia básica. 10. ed. São Paulo, SP: Guanabara Koogan, 2004.

KAVLOCK, R. J.; DATON, G. P.; DeROSA, C.; FENNER-CRISP, P.; GRAY, L.E.; KAATTARI, S.; LUCIER, G.; LUSTER, M.; MAC, M.J.; MACZKA, C.; MILLER, R.; MOORE, J.; ROLLAND, R.; SCOTT, G.; SHEEHAN, D.M.; SINKS, T.;TILSON, H.A. Research Needs for the Risk Assessment of Health and Environmental Effects of Endocrine Disruptors: A Report of the U.S. EPA-sponsored Workshop. Environmental Health Perspectives, v.104, 1996.

KOMATSU, E.; VAZ, J.M. Otimização de parâmetros de extração para determinação multiresíduo de pesticidas em amostras de água empregando microextração em fase sólida. Química Nova, v. 27, n. 5, 2004.

KRISHNAN, A.V.; STATHIS, P.; PERMUTH, S.F.; TOKES, L.; FELDMAN, D. Bisphenol$A$; a estrogenic substance is release from polycarbonate flasks during autoclaving. Endocrinology, v. 132, n. 6, 1993.

KUSTER, M.; AZEVEDO, D.A.; LÓPES de ALDA, M.J.; AQUINO NETO, F.R.; BARCELÓ, D. Analysis of phytoestrogens, progestogens and estrogens in environmental waters from Rio de janeiro (Brazil). Environment International, v. 35, p. 997-1003, 2009.

LANÇAS, F.M. Extração em fase sólida (SPE). São Carlos: RiMa, 2004a.

LANÇAS, F.M. Validação de métodos cromatográficos de análises. São Carlos: RiMa, 2004b.

LANG, I.A.; GALLOWAY, T.S.; SCARLETT, A.; HENLEY, W.E.; DEPLEDGE, M.; WALLACE, R.B.; MELZER, D. Association urinary bisphenol A concentration with medical disorders and laboratory abnormalities in adults. JAMA, v. 300, n. 11, 2008.

LEANDRO, F.Z. Bisfenol A: validação de método e ocorrência em água superficial e tratada da cidade de Araraquara. Dissertação de mestrado - Universidade Estadual Paulista, UNESP, São Paulo, 2006.

LEITE, F.. Validação em análise química. 5.ed. Campinas, SP: Editora Átomo, 2008.

LI, X.; YING, G.; SU, H.; YANG, X.; WANG, L. Simultaneous determination and assessment of 4-nonilphenol, bisphenol $A$ and triclosan in tap water, bottled water and baby bottles. Environ. International, v. 36, p. 557-562, 2010.

LINTELMANN, J.; KATAYAMA, A.; KURIHARA, N.; SHORE, L.; WENZEL, A. Endocrine disruptors in the environment - IUPAC Technical Report. Pure Appl. Chem. v. 75, n5, p. 631-681, 2003.

LIU, R.; ZHOU, J.L.; WILDING, A. Simultaneous determination of endocrine disrupting phenolic compounds and steroids in water by solid-phase extraction-gas chromatographymass spectrometry. Journal of Chromatography A, v. 1022, p. 179-189, 2004.

LOPEZ de ALDA, M.J.; DÍAS-CRUZ, S.; PETROVIC, M.; BARCELÓ, D. Liquid chromatography-(tandem) mass spectrometry of selected emerging pollutants (steroid sex hormones, drugs and alkylphenolic surfactants) in the aquatic environment. Journal of Chromatography A, v. 1000, p. 503-526. 2003. 
LOPEZ-ESPINOSA, M.J.; FREIRE, C.; ARREBOLA, J.P.; NAVEA, N.; TAOUFIKI, J.; FERNANDEZ, M.F.; BALLESTEROS, O. PRADA, R.; OLEA, N. Nonylphenol and octylphenol in adipose tissue of women in Southern Spain. Chemosphere, v. 76, p. 847852, 2009.

LOUREIRO, I.R. A importância e ocorrência de ftalatos em água potável e no ecossistema da Baía de Guanabara. 143p. Tese de Doutorado - Pontifica Universidade Católica, PUC, Rio de Janeiro, 2002.

LYONS, G.; AHRENS, A.; SALTER-GREEN, E. An environmentalist's vision of operationalizing the precaution principle in the management of chemicals. Int $\mathbf{J}$ Occup Environ Health, v. 6, n. 4, 2000.

MANOLI, E.; SAMARA, C. Polycyclic aromatic hydrocarbons in natural waters: sources, occurrence and analysis. Trends in Analytical Chemistry, v. 18, n. 6, p. 417-428, 1999.

MANSILHA, C.; REBELO, M.H.; FERREIRA, I.M.P.L.V.O.; PINHO, O.; DOMINGOS, V.; PINHO, C.; GAMEIRO, P. Quantification of endocrine disruptors and pesticides in water by gas chromatography-tandem mass spectrometry. Method validation using weighted linear regression schemes. Journal of Chromatography A, v. 1217, p. 6681-6691, 2010.

MAO, L.; SUN, C.; ZHANG, H.; LI, Y.; WU, D. Determination of environmental estrogens in human urine by high performance liquid chromatography after fluorescent derivatization with p-nitrobenzoyl chloride. Analytica Chimica Acta, v. 522, p. 241-246, 2004.

MARENGO, J.A.; ALVES, L.M. Tendências hidrológicas da bacia do rio Paraíba do Sul. Rev. Bras. Meteorologia, v.20, n. 2, 2005.

MATTHIESSEN, P. Topic 4.1. Historical Persperctive on endocrione disruption in wildlife. Pure appl. Chem., v.75, n.11-12. p.2197-2206. 2003.

McCULLAGH, J. Mass spectrometry. In: COOPER, C. (Ed.) Organic Chamist's Desk Reference. 2ed. CRC Press, 2011.

MENDIOLA, J.; JORGENSEN, N.; ANDERSSON, A.M.; CALAFAT, A.M.; YE, X.; REDMON, B.; DROBNIS, E.Z.; WANG, C.; SPARKS, A.; THURSTON, S.W.; LIU, F.; SWAN, S.H. Are environmental levels of bisphenol $A$ associated with reproductive function in fertile men? Environmental health perspectives, v. 118, p. 1286-1291, 2010.

MOL, H. G.J; SUNARTO, S.; STEIJGER, O.M. Determination of endocrine disruptors in water after derivatization with $\mathrm{N}$-methyl-N-(tert.-butyldimethyltrifluorcetamide) using gas chromatography with mass spectrometric detection. Journal of Chromatography A, v. 879, p. 97-112, 2000.

MORACI, L.F.S. Resíduos de agrotóxicos em lodo de estação de tratamento de água: validação de metodologia analítica utilizando cromatografia líquida acoplada à espectrometria de massas em tandem (LC-MS/MS). Dissertação de mestrado, Instituto de Pesquisas Energéticas e Nucleares - IPEN/USP, São Paulo, 2008.

MOREIRA, D.S. Desenvolvimento de metodologia analítica por cromatografia/espectrometria de massas para avaliação da ocorrência de pertubadores endócrinos em mananciais de abastecimento da região metropolitana de Belo Horizonte. Dissertação de mestrado, Universidade Federal de Ouro Preto, Minas Gerais, 2008.

MOREIRA, D.S.; AQUINO, S.F.; AFONSO, R.J.C. F.; SANTOS, E.P.P.C.; PÁDUA, V.L. Occurrence of endocrine disrupting compounds in water sources of Belo Horizonte Metropolitan Area, Brazil. Environmental Technology, v. 30, n.10, 2009. 
MÜLLER, S.; SCHMID, P.; SCHLATTER, C. Evaluation of the estrogenic potency of nonylphenol in non-occupationally exposed humans. Envir. Toxicology and Pharmacology, v. 6, p. 27-33. 1998a.

MÜLLER, S.; SCHMID, P.; SCHLATTER, C. Pharmacokinetic behavior of 4-nonylphenol in humans. Envir. Toxicology and Pharmacology, v. 6, p. 257-265. 1998b.

NAM, S.; SEO, Y.; KIM, M. Bisphenol A migration from polycarbonate baby bottle with repeated use. Chemosphere, v. 79, p. 949-952, 2010.

NIESSEN, W.M.A. Current Practice of Gas Chromatography-Mass Spectrometry. CRC Press, 2001.

NOLLET, L.M.L. Chromatographic Analysis of the Environment. 3ed. CRC Press, 2006.

NRC. National Research Council, Committee on the health risks oh phthalates. Phthalates and cumulative risk assessment the task ahead. Washington: National Academies Press, 2008.

OEHLMANN, J.; OETKEN, M.; SCHULTE-OEHLMANN, U. A critical evaluation of the environmental risk assessment for plasticizers in the freshwater environment in Europe, with special emphasis on bisphenol $A$ and endocrine disruption. Environmental research, v, 108, p. 140-149, 2008.

OLIVEIRA, D.P.; SILVA, F.V.; RODRIGUES, J.L.; BATISTA, B.L. Alquilfenóis e alquilfenóis etoxilados: uma visão ambiental. Rev. Bras. Toxicologia, v. 20, n. 1-2. 2007.

OLMO, M. del; GONZÁLEZ-CASADO, A.; NAVAS, N.A.; VILCHEZ, J.L. Determination of bisphenol $A(B P A)$ in water by gas chromatography-mass spectrometry. Analytica Chimica Acta, v. 346, p. 87-92, 1997.

OTOMO, J.I. Desenvolvimento e validação de metodologia analítica para determinação de hormônios, considerados disruptores endócrinos, nas águas destinadas ao abastecimento público na região do rio Paraíba do Sul, SP. Dissertação de mestrado, Instituto de Pesquisas Energéticas e Nucleares - IPEN/USP, São Paulo, 2010.

PAIXÃO, Y.N.F. Os problemas da gestão da bacia hidrográfica do rio Paraíba do Sul e suas consequências ambientais. In: XIII Simpósio Brasileiro de Geografia Física Aplicada da UFV, Viçosa, MG. 2009. Disponível em: http://www.geo.ufv.br/simposio/simposio/trabalhos/trabalhos_completos/eixo3/0100.pdf

PEIJNENBURG, W.J.G.M.; STRUIJS, J. Occurrence of phthalate esters in the environment of the Netherlands. Ecotoxicology and environmental safety, v. 63. p. 204-215, 2006.

PEREIRA, D.S.P. Governabilidade dos recursos hídricos no Brasil: a implementação dos instrumentos de gestão na bacia do Paraíba do Sul. Brasília: Agência Nacional das Águas, 2003.

PEREIRA NETTO, A.D..; MOREIRA, J.C.; DIAS, A.E.X.O.; ARBILLA, G.; FERREIRA, L.F.V.; OLIVEIRA, A.S.; BAREK, J. Avaliação da contaminação humana por hidrocarbonetos policíclicos aromáticos (HPAS) e seus derivados nitratos (NHPAS): uma revisão metodológica. Química Nova, v. 23, n. 6, p. 765-773, 2000. 
PETROVIC, M.; ELJARRAT, E.; Lopez de ALDA, M.J.; BARCELÓ, D. Recent advances in the mass spectrometric analysis related to endocrine disrupting compounds in aquatic environmental samples. Jounal of Chromatography A. v.974, p.23-51, 2002.

PINDAMONHANGABA. Portal da Prefeitura de Pindamonhangaba. Disponível em < http://www.pindamonhangaba.sp.gov.br/>. Acesso em 23 mar. 2011.

PORTO, M.F.A.; PORTO, R.L.L. Gestão de bacias hidrográficas. Estudos avançados, v. 22, n, 63, 2008.

RAIMUNDO, C.C.M. Ocorrência de interferentes endócrinos e produtos farmacêuticos nas águas superficiais da bacia do rio Atibaia. Dissertação de mestrado - Universidade Estadual de Campinas, UNICAMP, Campinas, 2007.

RAMLOGAN, R. Environment and human health: a threat to all. Envir. Management and health, v. 8/2, p. 51-66, 1997.

REACH - Registration, Evaluation, Authorisation and Restriction of Chemical substances. European Commission Environment. Disponível em: http://ec.europa.eu/environment/chemicals/reach/reach intro.htm. Acesso em: 25 fev. 2011.

REBOUÇAS, A.D. Água e desenvolvimento rural. Estudos Avançados, v.15, n.43, 2001.

REIS FILHO; R. W.; ARAÚJO, J. C.; VIEIRA, E.M.. Hormônios sexuais estrógenos: contaminantes bioativos. Química Nova, v.29, n.4, 2006.

REYS, L.L. Tóxicos Ambientais Desreguladores do Sistema Endócrino. Revista Faculdade de Medicina de Lisboa, serie III, v.6, n.4, p. 213-225, 2001.

REZAEE, M.; YAMINI, Y.; SHARIATI, S.; ESRAFILI, A.; SHAMSIPUR, M. Dispersive liquid-liquid microextraction combined with high-performance liquid chromatography-UV detection as a very simple, rapid and sensitive method for the determination of bisphenol A in water sample. Journal of Chromatography A, v. 1216, p. 1511-1514. 2009.

RIBANI, M.; BOTTOLI, C. B. G.; COLLINS, C. H.; JARDIM, I. C. S. F.; MELO, L. F. C. Validação em métodos cromatográficos e eletroforéticos. Química Nova, v. 27, n. 5, p. 771-780, 2004.

RICHARDSON, S.D. Environmental mass spectrometry: emerging contaminants and current issues. Anal. Chem., v. 82, n.12, p. 4742-4774, 2010.

RICHARDSON, S.D. Water analysis: emerging contaminants and current issues. Anal. Chem., v. 81, n. 12, p. 4645-4677, 2009.

RODIL, R.; QUITANA, J.B.; LÓPEZ-MAHÍA, P.; MUNIATEGUI-LORENZO, S.; PRADARODRÍGUEZ, D. Multi-residue analytical method for the determination of emerging pollutants in water by solid-phase extraction and liquid chromatography-tandem mass spectrometry. Journal of Chromatography A, v. 1216, p. 2958-2969, 2009.

SÁNCHEZ-ÁVILA, J.; BONET, J.; VELASCO, G.; LACORTE, S. Determination and occurrence of phthalates, alkylphenols, bisphenol A, PBDEs, PCBs, and PAHs in an industrial sewage grid discharging to a Municipal Wastewater Treatment Plant. Science of the Total Envir., v. 407, p. 4157-4167, 2009.

SANTODONATO, J. Review of the estrogenic and antiestrogenic activity of polycyclic aromatic hydrocarbons: relationship to carcinogenicity. Chemosphere, v. 34, n. 4, 1997. 
SANTOS, R.C.M.M.; PAIVA, S.C.; SALGUEIRO, A.A. Impacto na qualidade da água do rio Capibaribe por efluente de lavanderia e tinturaria industrial em Toritama, Pernambuco. In: A. S. Messias; M. R. N. Costa. (Org.). Água - Tratamentos e políticas públicas. Série Encontro das águas, n.04. Recife: UNICAP. Recife/PE, 2007.

SÃO JOSÉ DOS CAMPOS. Prefeitura da Cidade de São José dos Campos. Disponível em http://www.sjc.sp.gov.br/. Acesso em 23 mar. 2011.

SCHWARZENBACH, R. P.; ESCHER, B. I.; FENNER, K.; HOFSTETTER , T.B.; JOHNSON, C.A.; GUNTEN, U. VON, WEHRLI, B. The challenge of micropollutants in aquatic systems. Science, v. 313, p. 1072-1077, 2006.

SEILER, J.P. Pentachlorophenol. Mutation Research, v. 257, p. 27-47. 1991.

SERÔDIO, P.; NOGUEIRA, J.M.F. Considerations on ultra-trace analysis of phthalates in drinking water. Water research, v. 40, p. 2572-2582, 2006.

SIGRH - Sistema de Informações para o Gerenciamento dos Recursos Hídricos. São Paulo, 2011. Disponível em: < http://www.sigrh.sp.gov.br>. Acesso em 22 mar. 2011.

SIMPSON, N.J.K. Solid-phase extraction. Principles, techniques and applications. CRC Press, 2000.

SOARES, A.; GUIEYSSE, B.; JEFFERSON, B.; CARTMELL, E.; LESTER, J.N. Nonyphenol $n$ the environment: a critical review on occurrence, fate, toxicity and treatment in wastewaters. Environment International, v.34, p.1033-1049, 2008.

SODRÉ, F.F.; PESCARA, I.C.; MONTAGNER, C.C.; JARDIM, W.F. Assessing selected estrogens and xenoestrogens in Brazilian surface waters by liquid chromatographytandem mass spectrometry. Microchemical Journal, v. 96, p. 92-98, 2010.

STAPLES, C.A. PETERSON, D.R. PARKERTON, T. F. ADAMS, W.J. The environmental fate of phthalate esters: a literature review. Chemosphere, v. 35, n. 4, 1997.

STAPLES, C.A.; PHILIP, B.D.; KLECKA, G.M.; O'BLOCK, S.T.; HARRIS, L.R. A review on the environmental fate, effects, and exposure of bisphenol A. Chemosphere, v. 36, $\mathrm{n}$. 10, 1998.

SUMPTER, J.P. Xenoendocrine disrupters - environmental impacts. Toxicology letter, 102-103, 1998.

TAUBATÉ. Guia oficial on line. Disponível em http://www.taubatesp.com.br/informacoes.htm. Acesso em 23 mar. 2011.

THOMPSON, M.; ELLISON, S.L.R.; WOOD, R. Harmonized guidelines for singlelaboratory validation of method of analysis. IUPAC Technical Report. Pure Appl. Chem., v. 72, n. 5., p.835-855, 2002.

TUCCI, C.E.M. Águas urbanas. Estudos Avançados, v. 22, n. 63. 2008.

TUCCI, C.E.M..; HESPANHOL, I.; CORDEIRO NETTO, O.M. Gestão da Água no Brasil. UNESCO: Brasília, 2001.

TUNDISI, J.G. Recursos hídricos no future: problemas e soluções. Estudos Avançados, v. 22 , n. 63.2008.

USEPA - Unit States Environmental Protection Agency. Ambient Aquatic Life Water Quality Criteria - Nonylphenol. Washington, 2005. 
USEPA - United States Environmental Protection Agency. Bisphenol A Action Plan.

Washington, $2010 . \quad$ Disponível em: < http://www.epa.gov/oppt/existingchemicals/pubs/actionplans/bpa.html>. Acesso em 24 fev. 2010.

USEPA - United States Environmental Protection Agency. Evaluation and Estimation of Potential Carcinogenic Risks of Polynuclear Aromatic Hydrocarbons: Carcinogen Assessment Group. Office of Health and Environmental Assessment. Washington, 1995.

USEPA - United States Environmental Protection Agency. Drinking Water Contaminants. National Primary Drinking Water Regulations. Disponível em: $<$ http://water.epa.gov/drink/contaminants/index.cfm>. Acesso em 24 fev. 2011b.

USEPA - United States Environmental Protection Agency. Method 1694 Pharmaceuticals and Personal Care Products in Water, Soil, Sediment, and Biosolids by HPLC/MS/MS. Washington, Dezembro, 2007a.

USEPA - United States Environmental Protection Agency. Method 1698 - Steroids and Hormones in Water, Soil, Sediment and Biosolids by HRGC/HRMS. Washington, Dezembro, 2007b.

USEPA - United States Environmental Protection Agency. National Recommended water Quality Criteria. Washington, 2009. Disponível em: $<$ http://water.epa.gov/scitech/swguidance/waterquality/standards/current/upload/nrwqc2009.pdf >. Acesso em 25 fev. 2011.

USEPA - United States Environmental Protection Agency. Research Plan for Endocrine Disruptors, Washington, 1998.

USEPA - United States Environmental Protection Agency. Reregistration Eligibility Decision for Pentachlorophenol. Washington, 2008.

USEPA - United States Environmental Protection Agency. Safe Drinking Water Act (SDWA). Disponível em: < http://water.epa.gov/lawsregs/rulesregs/sdwa/>. Acesso em 24 fev. 2011a.

USEPA - United States Environmental Protection Agency. Soils Screeninng Guidelines. 1996. Disponível em; < http://www.epa.gov/oerrpage/superfund/health/conmedia/soil/toc.htm>. Acesso em 25 fev. 2011.

VALENTE, A.L.P.; AUGUSTO, F. Microextração em fase sólida. Química Nova, v. 23, n. 4, 2000.

VANDER HEYDEN, Y.; NIJHUIS, A.; SMEYERS-VERBEKE, J.; VANDEGINSTE, B.G.M.; MASSART, D.L. Guidance for robustness/ruggedness test in method validation. J. pharmaceutical and biomedical analysis, v. 24, p. 723-753, 2001.

VAN WEZEL, A.P.; van VLAADINGEN, P.; POSTHUMUS, R.; CROMMENTUIJN, G.H.; SIJM, D.T.H.M. Environmental risk limits for two phthalate, with special emphasis on endocrine disruptive properties. Ecotoxicology and environmental safety, v. 46, p. 305$321,2000$.

VEGA-BUSTILLOS, O.; SASSINE, A.; MARCH, R. A espectrometria de massas quadrupolar. São Paulo, 2001. 
VINGGAARD, A.M.; HNIDA, C.; LARSEN, J.C. Environmental polycyclic aromatic hydrocarbons affect androgen receptor activation in vitro. Toxicology, v. 145, p. 173-183, 2000.

VOGEL, S.A. The politics of plastics: the making and unmaking of bisphenol A "safety". American journal of public health, v. 99, n. S3, 2009.

WILSON, N.K.; CHUANG, J.C.; MORGAN, M.K. LORDO, R.A.; SHELDON, L.S. An observational study of the potential exposures of preschool children to pentachlorophenol, bisphenol-A, and nonylphenol at home and daycare. Environmental Research, v. 103, p. 9-20. 2007.

WHO - World Health Organization. Guidelines for Drinking-water Quality. 3ed. WHO Library: Geneva, 2008.

YANG, N.C.; CASTRO, A.J.; LEWIS, M.; WONG, T. Polynuclear Aromatic hydrocarbons, Steroids and Carcinogenesis. Science, v.134, p. 386-387, 1961.

YING, G. Analysis of endocrine disrupting chemicals and pharmaceuticals and personal care products in water. IN: NOLLET, L.M.L (Ed.) Handbook of water analysis. CRC Press, 2007.

YING, G.; WILLIAMS, B.; KOOKANA, R. Environmental fate of alkylphenols and alkylphenol ethoxylates - a review. Environment International, v.28, p. 215-226. 2002.

YU, Z.; PELDSZUS, S.; HUCK, P.M.; Optimizing gas chromatography-mass spectrometric analysis of selected pharmaceuticals and endocrine-disrupting substances in water using factorial experimental design. Journal of Chromatography A, 1148, p. 65-77, 2007.

YUWONO, M.; INDRAYANTO, G. Gas chromatography. In: CAZES, J. (Ed.) Analytical Instrumentation Handbook. 2ed. CRC Press, 2004.

ZAFRA, A.; del OIMO, M.; SUÁREZ, B.; HONTORIA, E.; NAVALÓN, A.; VÍLCHEZ, J.L. Gas chromatographic-mass spectrometric method for the determination of bisphenol $A$ and its chlorinated derivatives in urban wastewater. Water research, v. 37, p. 735-742, 2003.

ZAFRA-GOMÉZ, A.; BALLESTEROS, O.; NAVALÓN, A.; VÍLCHEZ, J.L. Determination of some endocrine disrupters chemicals in urban wastewater samples using liquid chromatography - mass spectrometry. Microchemical Journal, v. 88, p. 87-94. 2008.

ZHOU, Y.; JIANG, Q.; PENG, Q.; XUAN, D.; QU, W. Development of a solid hase microextraction-gas chromatography-mass spectrometry method for the determination of pentachlorophenol in human plasma using experimental design. Chemosphere, v. 70, p. 256-262, 2007. 